\title{
Labor Mobility As a Jobs Strategy for Myanmar
}

STRENGTHENING ACTIVE LABOR MARKET POLICIES TO ENHANCE THE BENEFITS OF MOBILITY

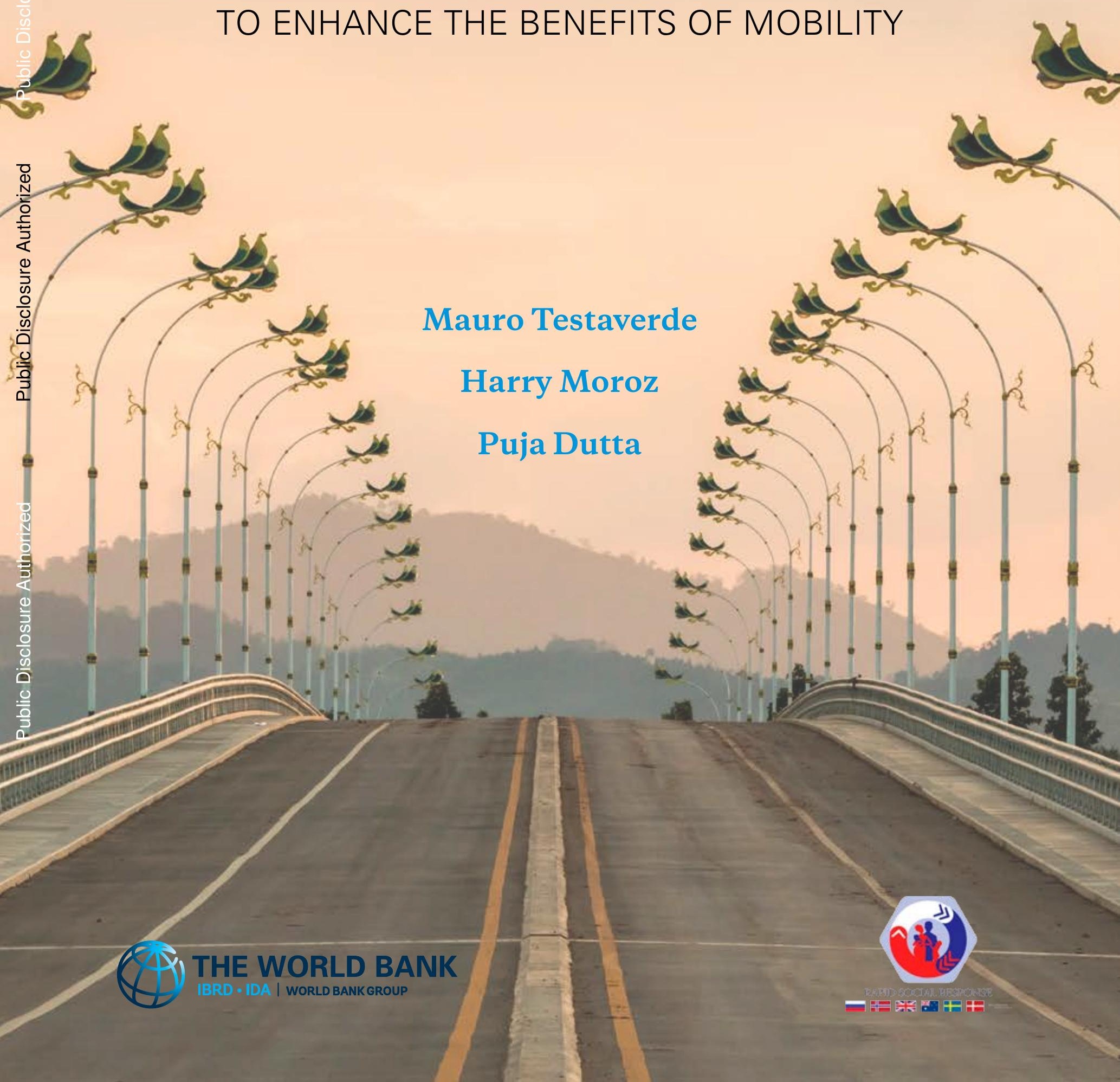




\title{
Labor Mobility As a Jobs Strategy for Myanmar
}

STRENGTHENING ACTIVE LABOR MARKET POLICIES TO ENHANCE THE BENEFITS OF MOBILITY

\section{Mauro Testaverde}

Harry Moroz

\author{
Puja Dutta
}





\section{Foreword}

obs are a key ingredient of Myanmar's development. Significant economic reforms have facilitated an economic transformation that has led to job growth that averaged 13 percent annually between 2014 and 2016. There are now more than 24 million jobs in Myanmar that are the main source of income for households. These jobs provide a path out of poverty and can bolster social cohesion in a country grappling with ongoing conflict. The Myanmar Sustainable Development Plan (2018-2030), a national strategy to inform policies and institutions that drive inclusive and transformational economic growth, recognizes that jobs are one of the foundations of Myanmar's economic development. One of the plan's five goals is devoted to job creation and private sector-led growth.

However, jobseekers in Myanmar are often in different locations than job opportunities, particularly the good ones. As a result, 4.7 million people, or nearly one in ten people, had moved from their usual place of residence in the five years preceding the 2014 Census, most of them migrants for work. Indeed, much migration flows to Myanmar's dynamic economic centers, particularly Mandalay and Yangon, as well as beyond Myanmar's borders to Thailand, Malaysia, and more distant countries. These people move in search of higher-paying jobs that can support families back home. The average monthly wage in Myanmar was about US\$60 per month in 2015; Myanmar migrant workers in Thailand make around three times that amount. The benefits of these jobs come in the form of remittances that can reduce poverty, lead to new skills, and shift gender norms.

People on the move face different types of risks than other jobseekers, and so strategies to increase their access to high quality and inclusive jobs in Myanmar must take these risks into account. Internal and international migrant workers face higher costs to look for jobs, which can deter mobility or lead them to choose informal channels. Myanmar migrants using informal channels to migrate to Thailand spend around 30 days and US\$536 versus 45 days and US\$794 for those using formal channels. Though informal channels may have lower initial costs, informal migrants tend to earn less and send home fewer remittances, meaning that the net benefits of migration and its ultimate benefits for Myanmar may be reduced. For instance, a recent survey found that three-quarters of regular migrants were paid above the minimum wage versus less than half of that for irregular ones. Irregular migrants are also more likely to report problems during migration. These unique experiences mean that measures to increase access to good jobs must be tailored to the needs of jobseekers who are on the move.

Labor Mobility As a Jobs Strategy for Myanmar shows how active labor market policies that aim to generate more and better employment opportunities can be adjusted to the needs of jobseekers on the move. The report examines these 


\section{Myanmar migrants using informal channels to migrate to Thailand spend around 30 days and US\$536 versus 45 days and US\$794 for those using formal channels.}

adjustments for different types of active labor market policies. Labor market data can be expanded to include information about safety, particularly about avoiding human trafficking. Job matching and placement may require both a more active private-sector recruitment industry and more active government oversight. Training should incorporate knowledge about the demand from firms overseas, and it may also involve soft skills and safe migration training. Financial products can be tailored to alleviate credit constraints based on the remittance-linked income streams of migrants. Notably, these policies need not promote migration; some may even reduce the incentives for migration by improving access to income-generating opportunities at home.

The government recognizes the important role of mobility in Myanmar's labor markets. The Myanmar Sustainable Development Plan includes components related to migration, including a strategy to promote legal, affordable, and secure migration to increase the contribution that migration makes to development. The government has also published two national plans of action on international migration that would increase development impacts. However, additional efforts could strengthen the positive impacts that migration has already had for Myanmar's development. This report shows how Myanmar's initial efforts can be expanded through a fourpronged strategy of short- and longer-term actions to deploy strategic investment to strengthen employment services, improve coordination to fill gaps in services, use technology to improve the efficiency of service delivery, and leverage data to inform investment, coordination, and technology. Undertaking such a strategy would help more people in Myanmar access good jobs.

\author{
Daniel Dulitzky \\ Regional Director \\ East Asia and Pacific Region \\ The World Bank Group
}

\author{
Michal Rutkowski \\ Global Director \\ Social Protection and Jobs Global Practice \\ The World Bank Group
}




\section{Acknowledgments}

T his report was written by a team led by Mauro Testaverde (Task Team Leader and Senior Economist) and that included Harry Moroz (Economist) and Puja Dutta (Senior Economist). Mahesh Dahal (Research Assistant), Ashish Joshi (IT Specialist), Lydia Kim (Economist), Aung Naing Oo (Analyst), and Soonwha Yi (Senior Economist) provided inputs. The report was informed by joint field assessments conducted by the Center for Economic and Social Development (CESD) and the World Bank team between February and July 2018 in Ayeyarwady, Bago, Kayin, Magwe, Mandalay, Mon, Tanintharyi, and Yangon.

The report team is grateful for the leadership of the Department of Labor (DOL) in the Myanmar Ministry of Labor, Immigration and Population (MOLIP) throughout the course of the assignment. In particular, the team would like to thank the Director General of DOL, $U$ Win Shein, the Director of the Local Employment Section, Daw Tin Tin Htay, and the Director of the Migrant Workers Section, Daw Aye Aye Moe, for their support and guidance. The team is extremely thankful to the staff in the Labor Exchange Offices and the other government offices in Ayeyarwady, Bago, Kayin, Magwe, Mandalay, Mon, Tanintharyi, and Yangon for their time and hospitality. Additionally, the team would like to thank the CESD team, and in particular, Dr. Zaw Oo (Executive Director) and U Min Zarni Lin (Deputy Research Director), for the productive collaboration.

The report benefited from several rounds of discussions with MOLIP staff and from feedback from the staffs of the International Organization of Migration (IOM) and the International Labor Organization (ILO) in Yangon. In particular, the authors thank Jackie Pollock (ILO) and Michiko Ito (former IOM staff) for useful suggestions and material. The team also benefited from discussions with other organizations in Myanmar, including the Union of Myanmar Federation Chambers of Commerce and Industry, Myanmar Overseas Employment Agencies Federation and member overseas employment agencies, the International Growth Center Myanmar, UN Women, the United Nations Capital Development Fund (UNCDF), the Issara Institute, MyJobs, JobNet, Jobs in Yangon, internal recruitment agencies, Trust Link, the Centre for Vocational Training, and Koe Koe Tech.

The report team would like to thank the members of the Migration Group chaired by the Livelihoods and Food Security Fund (LIFT) for facilitating field visits and for sharing useful material. Special thanks go to BRAC, Business Kind Myanmar, HelpAge, Helvetas, ILO, Issara Institute, IOM, Karuna Mission Social Solidarity, LIFT, Mercy Corps, Metta Development Foundation, Mon Baptist Convention, Mon Women's Organization, Myanmar Baptist Convention, Swisscontact, UNCDF, and World Vision, as well as to the local CSOs, migrants, and migrant-sending households in Ayeyarwady, Bago, Kayin, Magwe, Mandalay, Mon, Tanintharyi, and Yangon for the useful meetings and discussions during field visits. The team is also grateful to Anna Platonova (IOM Bangkok) and the IOM staff in Mae Sot (Thailand) for the useful discussions during the field visit on the Thai border.

During the preparation of the report, the team also received insightful comments and useful material from: Syud Amer Ahmed, Reena Badiani-Magnusson, Yoonyoung Cho, Wendy Cunningham, Giorgia Demarchi, Clarence Tsimpo Nkenge, Emilie Bernadette Perge, Josefina Posadas, Ririn Salva Purnamasari, and Rebekah Lee Smith. Su Su Htay, Kyaw Soe Lynn, Arnold Marseille, and Tin Hnin Yu 


\section{Contents}

Foreword

iii

Acknowledgments $\quad$ v

Abbreviations $\quad$ ix

$\begin{array}{ll}\text { Introduction } & 1\end{array}$

$1 \quad$ Labor Mobility in Myanmar: Drivers, Impacts, Opportunities, 9 and Barriers

Main trends and issues in the Myanmar labor market $\quad 10$

$\begin{array}{ll}\text { Patterns of migration } & 15\end{array}$

Drivers of migration $\quad 26$

Positive impacts of migration $\quad 31$

Unintended consequences of migration $\quad 42$

Migration's unrealized potential $\quad 48$

$\begin{array}{ll}\text { Conclusion } & 51\end{array}$

2 Active Labor Market Policies for Myanmar Workers in Myanmar 61

Introduction $\quad 62$

$\begin{array}{ll}\text { Legal and institutional framework } & 63\end{array}$

$\begin{array}{ll}\text { Training } & 68\end{array}$

Labor market information $\quad 74$

Job matching and placement $\quad 82$

$\begin{array}{ll}\text { Financial assistance } & 90\end{array}$

$\begin{array}{ll}\text { Conclusion } & 91\end{array}$

3 Active Labor Market Policies for Myanmar Workers Abroad 95

Introduction $\quad 96$

Legal and institutional framework $\quad 96$

$\begin{array}{lr}\text { Training } & 112\end{array}$

Labor market information $\quad 119$

Job matching and placement $\quad 122$

Financial assistance 136

$\begin{array}{ll}\text { Conclusion } & 138\end{array}$ 
Rationalizing the legislative and institutional framework supporting migrants and ALMPs

Transitioning to an employer-driven skills strategy for training

Expanding access to labor market information

Developing targeted job-matching and -placement services

\section{Intenational Spotlights}

1 Improving access to training for in-demand skills in China

2 Adapting training programs in Pakistan and the Philippines to the skills needed abroad

3 Predeparture orientation in the Philippines

4 Providing financial literacy education in Indonesia

5 Encouraging formal remittances in Malaysia and Indonesia

6 Delivering post-arrival orientation to migrant workers from the Philippines and Indonesia

7 Evidence from around the world on the importance of labor market information

8 Improving access to labor market information for migrants in the Philippines

9 Strengthening public employment services in China

10 Providing recruitment services to increase the employment of

11 The market for employment services in Australia

12 Migrant worker welfare funds in the Philippines and in India

13 Engaging diaspora from countries around the world

14 Providing transportation subsidies in Bangladesh $\quad 175$

15 Providing migration loans to international migrants in Bangladesh 175

16 Reintegrating returning migrants in the Philippines 


\section{Abbreviations}

\begin{tabular}{|c|c|}
\hline ASEAN & Association of Southeast Asian Nations \\
\hline ALMPs & Active Labor Market Policies \\
\hline CESD & $\begin{array}{l}\text { Centre for Economic and } \\
\text { Social Development }\end{array}$ \\
\hline CHIME & $\begin{array}{l}\text { Capitalizing Human Mobility for Poverty } \\
\text { Alleviation and Inclusive Development } \\
\text { in Myanmar }\end{array}$ \\
\hline CSO & Civil Society Organization \\
\hline CSO & Central Statistical Organization \\
\hline CVT & Centre for Vocational Training \\
\hline EPS & Employment Permit System (Korea) \\
\hline GAD & General Administration Department \\
\hline GIZ & $\begin{array}{l}\text { Deutsche Gesellschaft für Internationale } \\
\text { Zusammenarbeit }\end{array}$ \\
\hline GTHS & Government Technical High School \\
\hline GTI & Government Technical Institute \\
\hline HRDI & $\begin{array}{l}\text { Human Resources Development } \\
\text { Institute }\end{array}$ \\
\hline $\mathrm{HTI}$ & Hotel and Tourism Industry \\
\hline ICWF & Indian Community Welfare Fund (India) \\
\hline ILO & International Labour Organization \\
\hline IOM & International Organization for Migration \\
\hline ISCO & $\begin{array}{l}\text { International Standard Classification of } \\
\text { Occupations }\end{array}$ \\
\hline IT & Information Technology \\
\hline LEO & Labor Exchange Office \\
\hline LFS & Labor Force Survey \\
\hline LROE & Law Relating to Overseas Employment \\
\hline LVT & Local Vocational Training program \\
\hline MILDAS & $\begin{array}{l}\text { Migration as a Livelihood Diversification } \\
\text { Strategy in the Delta }\end{array}$ \\
\hline MLCS & Myanmar Living Conditions Survey \\
\hline MMK & Myanmar Kyat \\
\hline MOALI & $\begin{array}{l}\text { Ministry of Agriculture, Livestock, } \\
\text { and Irrigation }\end{array}$ \\
\hline MOC & Memorandum of Cooperation \\
\hline MOE & Ministry of Education \\
\hline MOEAF & $\begin{array}{l}\text { Myanmar Overseas Employment } \\
\text { Agencies Federation }\end{array}$ \\
\hline $\mathrm{MC}$ & $\begin{array}{l}\text { Ministry of Employment and Labor } \\
\text { (Korea) }\end{array}$ \\
\hline MOLIP & $\begin{array}{l}\text { Ministry of Labor, Immigration, } \\
\text { and Population }\end{array}$ \\
\hline
\end{tabular}

\begin{tabular}{|c|c|}
\hline 100 & Memorandum of Understanding \\
\hline APLCS & $\begin{array}{l}\text { Myanmar Poverty and Living Conditions } \\
\text { Survey }\end{array}$ \\
\hline ARC & Migrant Resource Center \\
\hline GO & Nongovernmental Organization \\
\hline PA & lational Plan for Action \\
\hline $\mathrm{RC}$ & National Registration Card \\
\hline ECC & $\begin{array}{l}\text { Overseas Employment Central } \\
\text { Committee }\end{array}$ \\
\hline ESC & $\begin{array}{l}\text { Overseas Employment Supervisory } \\
\text { Committee }\end{array}$ \\
\hline WIC & Overseas Worker Identification Card \\
\hline WW & $\begin{array}{l}\text { Overseas Workers Welfare } \\
\text { Administration (Philippines) }\end{array}$ \\
\hline EOS & $\begin{array}{l}\text { Pre-Employment Orientation Seminar } \\
\text { (Philippines) }\end{array}$ \\
\hline 1 & Job F \\
\hline OEA & $\begin{array}{l}\text { Public Overseas Employment Agency } \\
\text { (Myanmar) }\end{array}$ \\
\hline OEA & $\begin{array}{l}\text { Philippines Overseas Employment } \\
\text { Administration }\end{array}$ \\
\hline SDF & kills Development Fund \\
\hline RAICES & $\begin{array}{l}\text { ers and Scientists Abroad } \\
\text { (Argentina) }\end{array}$ \\
\hline ME & Small and Medium-Sized Enterprises \\
\hline MS & Short Me \\
\hline ESDA & $\begin{array}{l}\text { Technical Education and Skills } \\
\text { Development Authority (Philippines) }\end{array}$ \\
\hline THB & Thai Baht \\
\hline TVET & $\begin{array}{l}\text { Technical and Vocational Education } \\
\text { and Training }\end{array}$ \\
\hline$r$ & United Nations \\
\hline UNL & $\begin{array}{l}\text { United Nations Development } \\
\text { Programme }\end{array}$ \\
\hline $\mathrm{UN}^{\top}$ & United Nations Technical Working Gro \\
\hline USs & tates Dollar \\
\hline D & Visa with Reference (I \\
\hline VSDF & Vocational Skills Development F \\
\hline
\end{tabular}





\section{Introduction}

he government of Myanmar is committed to creating new and better jobs, including for migrant workers. In 2018, they introduced the Myanmar Sustainable Development Plan (2018-2030), a national strategy to inform policies and institutions that drive inclusive and transformational economic growth. Goal 3 of that plan focuses on job creation and private sector-led growth, and it includes separate strategies for job creation in rural areas, in industry and services, and in small and medium enterprises (SMEs); another part of Goal 3 addresses the need to improve the enabling environment for investment. Protecting the rights and harnessing the benefits of work, including for migrant workers, is likewise addressed in the government's plan. The Ministry of Labor, Immigration, and Population also released two National Plans of Action that highlight the importance of migration for Myanmar and the need to improve its management. 
Achieving the goals of this jobs agenda requires overcoming significant constraints (Cunningham and Muñoz 2018). While there are more than 24 million jobs in Myanmar, which are the main source of income for households, the high-quality and inclusive jobs that lead to more growth and enhanced well-being are limited. Constraints to creating new and better jobs range from weaknesses in macroeconomic management to low agricultural productivity, low levels of private-sector engagement in the global economy, lack of access to land for SMEs, and an inadequately trained workforce. Additionally, jobs are not evenly distributed throughout Myanmar; most job growth is concentrated in its main economic centers, Yangon and Mandalay, with much less economic activity outside of these urban agglomerations.

Widespread and longstanding conflict in Myanmar exacerbates these challenges. Civil conflict is ongoing, and subnational conflict impacts one-third of townships in the country, which has resulted in the loss of thousands of lives and cost valuable public resources. A range of factors can inhibit job creation in conflict-affected areas, including the lack of functioning markets, weak institutions, weak connections to the larger economy, lack of investment due to uncertainty, and less asset ownership by households. Conflict can also lead households to migrate in search of safety, stability, and income. In the border states, in particular, migration across the border

\section{$10 \%$}

\section{Percentage of the population that moved from their usual place of residence in the five years preceding the 2014 Census}

has been a response to conflict and political factors.

In a well-functioning labor market, matches between jobseekers and employers occur quickly and easily. However, market failures can mean that access to training is limited, labor market information is incomplete, and access to credit is inadequate. Firms may underinvest in training because they fear that workers will leave once (transferrable) skills are learned. Jobseekers lack information about employers and employers about jobseekers, with the result that job search costs are inefficiently high. Failures in credit markets mean that poor households cannot finance job searches or launch selfemployment activities. Symptoms of these problems have arisen in Myanmar, where access to training is limited, labor market information is incomplete, and access to credit is inadequate.

These breakdowns in the labor market can be particularly severe when jobs are remote. Myanmar is a highly mobile country-nearly 10 percent of the population had moved from their usual place of residence in the five years preceding the 2014 Census (Figure I.1) -and most of these migrants are looking for work (Figure 1.2). Credit constraints and lack of information about in-country and international job opportunities can inhibit job searches in more distant locations and can lead migrants to use informal brokers or channels. These channels may be faster and cheaper than the official ones, but informal migrants tend to earn less and send home fewer remittances, which means that the net benefits of migration for families and its ultimate benefits for Myanmar are reduced (Figures 1.3 and 1.4). Firms' incentives for training international migrants may be even weaker than for domestic workers, because international migrants often have time-limited work permits, reducing the time horizon over which firms can expect a return on their training investment. 
Figure I.1

Myanmar is a highly mobile country...

\begin{tabular}{|c|c|}
\hline $\begin{array}{l}\text { Within states } \\
\text { and regions }\end{array}$ & 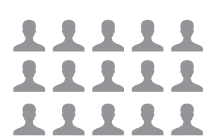 \\
\hline $\begin{array}{l}\text { Between states } \\
\text { and regions }\end{array}$ & $\begin{array}{l}12121 \\
218 \\
212 \\
121\end{array}$ \\
\hline International & $\begin{array}{l}1218 \\
212 \\
121\end{array}$ \\
\hline
\end{tabular}

$1=100,000$ migrants

Source: Department of Population 2016.

Figure I.3

Formal migrants are more likely to earn higher wages...

\section{Formal migrants}

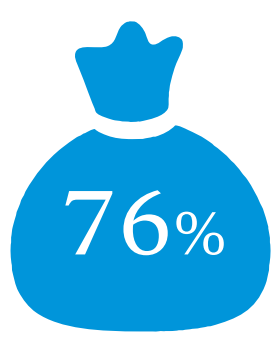

Paid above minimum wage

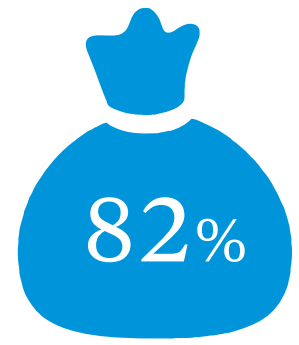

Send remittances
Source: IOM 2019.

Active labor market policies (ALMPs) aim to address these market failures in order to generate more and better employment opportunities for workers (McKenzie 2017). These policies include skills training programs that increase employability and self-employment, subsidies that

\section{Figure I.2}

in which most migrants move for work

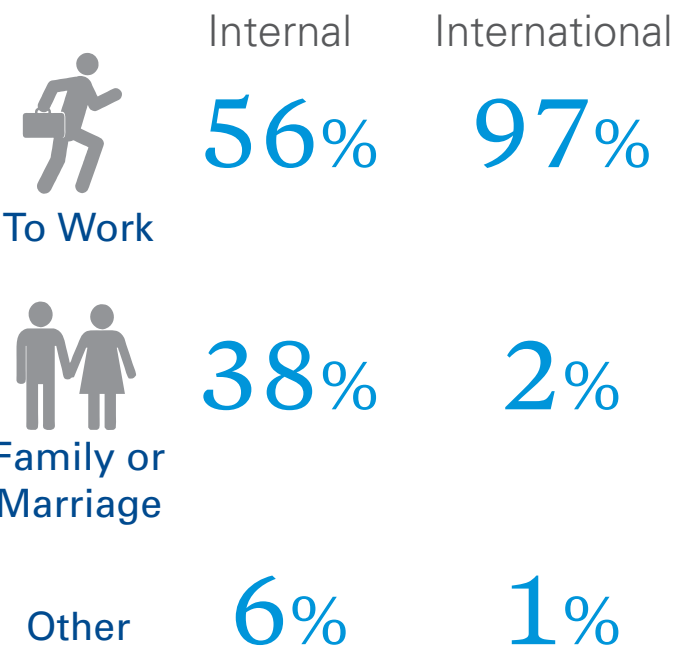

Source: Cunningham and Muñoz 2018.

Figure I.4

and send remittances

Migrants with no documentation

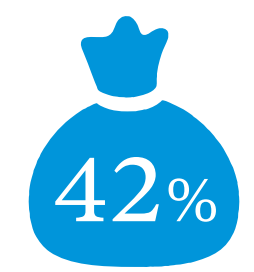

Paid above minimum wage

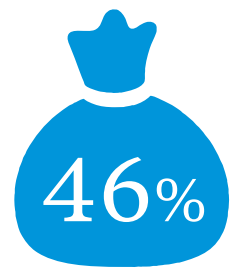

Send remittances
Source: IOM 2019.

increase the demand for workers and opportunities for entrepreneurship, and job-matching and -placement services that help match workers to jobs. It has been shown that ALMPs can lead to higher employment rates and, to a lesser extent, higher earnings (Betcherman and Moroz 


\section{Box I.1 The jobs agenda for Myanmar}

Myanmar's Future Jobs report proposes a jobs agenda that would create more jobs, improve existing ones, and make jobs more inclusive in Myanmar. The proposed agenda recognizes that targeted policies across different sectors of the economy are necessary to achieve the objectives of more, better, and more inclusive jobs. In other words, economic growth and a conducive investment climate alone are insufficient. Actions are recommended across a wide range of policy areas, and several of them incorporate elements of ALMPs; these include enhancing the skills of the labor force by improving access to and the quality of training; placing the right workers in the right jobs by strengthening labor market information; and increasing the productivity of household enterprises through entrepreneurial skills training. ALMPs thus play a critical role in Myanmar's jobs agenda.

\begin{tabular}{|c|c|c|}
\hline Policy area & Goal & $\begin{array}{l}\text { Link to } \\
\text { ALMPs? }\end{array}$ \\
\hline $\begin{array}{l}\text { Improve fiscal and monetary } \\
\text { policies to create a more } \\
\text { conducive macro environment } \\
\text { for job creation }\end{array}$ & $\begin{array}{l}\text { - Improve clarity, communication, and credibility of } \\
\text { - Maintain price stability and exchange rate flexibility }\end{array}$ & \\
\hline $\begin{array}{l}\text { Create a conducive legal } \\
\text { environment for firm creation, } \\
\text { growth, and diversification }\end{array}$ & $\begin{array}{l}\text { - Reduce the costs of doing business through } \\
\text { legislation, public goods, and active incentives in } \\
\text { certain sectors }\end{array}$ & \\
\hline $\begin{array}{l}\text { Invest in jobs-friendly global } \\
\text { value chains }\end{array}$ & $\begin{array}{l}\text { - Lower trade costs, facilitate foreign direct } \\
\text { investment, foster domestic links with buyers, and } \\
\text { raise the absorptive capacity of domestic enterprises } \\
\text { to benefit from spillovers }\end{array}$ & \\
\hline $\begin{array}{l}\text { Develop agriculture value } \\
\text { chains to build up the rural } \\
\text { micro and small enterprise } \\
\text { sector }\end{array}$ & $\begin{array}{l}\text { - Substitute higher-value crops for rice production, } \\
\text { increase access to and availability of capital to } \\
\text { farmers, increase links to markets, and construct } \\
\text { storage facilities }\end{array}$ & $x$ \\
\hline $\begin{array}{l}\text { Lower the costs of migration, } \\
\text { including for jobs outside of } \\
\text { Myanmar }\end{array}$ & $\begin{array}{l}\text { - Provide information and resources to facilitate } \\
\text { migration }\end{array}$ & $x$ \\
\hline $\begin{array}{l}\text { Increase the productivity of } \\
\text { household enterprises }\end{array}$ & $\begin{array}{l}\text { - Foster better links with the large firms in the formal } \\
\text { sector }\end{array}$ & $x$ \\
\hline $\begin{array}{l}\text { Enhance the skills of the labor } \\
\text { force }\end{array}$ & $\begin{array}{l}\text { - Improve educational relevance by moving teaching } \\
\text { away from degrees and diplomas and toward } \\
\text { workplace skills }\end{array}$ & $x$ \\
\hline $\begin{array}{l}\text { Place the right workers in the } \\
\text { right jobs }\end{array}$ & $\begin{array}{l}\text { - Create and disseminate labor market information and } \\
\text { expand information on job vacancies }\end{array}$ & $x$ \\
\hline $\begin{array}{l}\text { Enhance agricultural } \\
\text { productivity }\end{array}$ & - Modernize and diversify activities in rural areas & $x$ \\
\hline $\begin{array}{l}\text { Rebuild job opportunities in } \\
\text { conflict-affected zones }\end{array}$ & $\begin{array}{l}\text { Provide short-term financing to accumulate assets } \\
\text { and develop micro industries that can be linked to } \\
\text { existing markets }\end{array}$ & $x$ \\
\hline
\end{tabular}


2018). Still, ALMPs are only one part of a larger jobs agenda, and they have had positive impacts in some cases but not in others. The more effective programs tend to be targeted to specific groups and are designed with those groups in mind (Betcherman and Moroz 2018). Importantly for Myanmar, the most promising programs seem to be those that facilitate access to different labor markets and help overcome the mismatches in supply and demand that arise across space and across sectors (McKenzie 2017).

If deployed in Myanmar, different categories of ALMPs can address the market failures that have led to its labor market inefficiencies. Training financed by the government can increase investment in human capital to an efficient level. Labor market information and job-matching and -placement services can reduce job search costs and result in more efficient matches. Financial support can allow households to invest in income-generating activities. These actions would help both migrants and nonmigrants.

However, ALMPs must be targeted to the needs of migrant jobseekers. Labor market information should list the rules and regulations related to migration in addition to information about job vacancies. Information about safety, particularly about avoiding human trafficking, is particularly important. Job matching and placement may require both a more active privatesector recruitment industry and more active government oversight. Training must incorporate knowledge about the demand from firms overseas, and it may also involve soft skills and safe migration training. Financial products can be tailored to alleviate credit constraints based on the remittance-linked income streams of migrants. Notably, ALMPsneed not promote migration; some ALMPs expand livelihood opportunities at home through training

\section{If deployed in Myanmar, different categories of ALMPs can address the market failures that have led to its labor market inefficiencies}

and financial assistance that stimulates self-employment and entrepreneurship. In these cases, ALMPs may even reduce the incentives for migration by improving access to income-generating opportunities at home. Figure 1.5 summarizes the market failures that can motivate the need for ALMPs and how ALMPs can be adapted to the needs of migrants.

The report is divided into four chapters. The first chapter provides a detailed overview of labor mobility in Myanmar. The second chapter introduces ALMPs in Myanmar with a focus on internal migrants. Chapter 2 covers the legal and institutional framework governing ALMPs and then discusses training, labor market information, job matching and placement, and financial assistance. Areas for improvement and gaps are discussed in each section. Chapter 3 follows this same structure for international migrants. As noted above, conflict is an important challenge for labor markets in Myanmar. Chapters 3 and 4 focus on policies related to labor mobility, including labor mobility motivated by conflict, but they do not address the particular needs of people displaced by conflict. Chapter 4 recommends policy changes that would improve the labor mobility situation in Myanmar and fill the gaps identified in Chapters 2 and 3. 


\section{Figure I.5}

Typology of active labor market policies in the context of migration

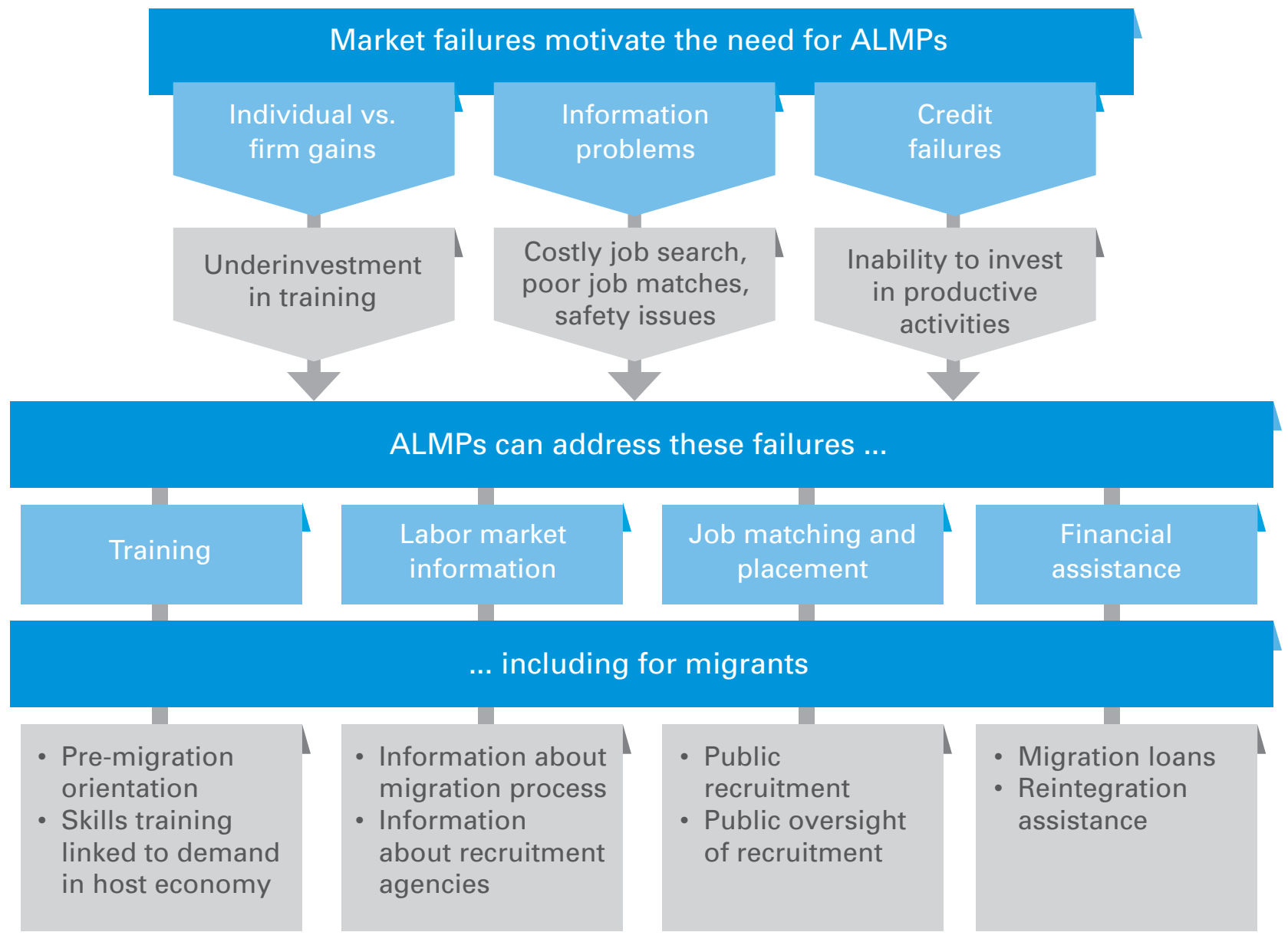




\section{References}

Betcherman, Gordon, and Harry Moroz. 2018. "Employment Programs as a Social Protection Instrument in East and South Asia," Background paper for East Asia and the Pacific regional report on social protection.

Cunningham, Wendy, and Rafael Muñoz. 2018. Myanmar Future Jobs: Embracing Modernity: Overview. Yangon: World Bank.

Department of Population. 2016. Thematic Report on Migration and Urbanization: Census Report Volume 4-D. Department of Population, Ministry of Labor, Immigration and Population, Republic of the Union of Myanmar.

IOM (International Organization for Migration). 2019. "Flow Monitoring Surveys: Insights into the Profiles and Vulnerabilities of Myanmar Migrants to Thailand (Round Three)." International Organization for Migration, Bangkok.

McKenzie, David. 2017. "How Effective Are Active Labor Market Policies in Developing Countries? A Critical Review of Recent Evidence," The World Bank Research Observer 32:127-54. 


\section{CHAPTER \\ 1 Labor Mobility in Myanmar: Drivers, Impacts, Opportunities, and Barriers}

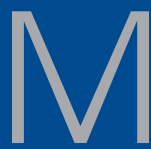

igration for work is an important livelihood strategy for a large number of people in Myanmar. Between 2009 and 2014, approximately 4.7 million people had moved within Myanmar, while another 4.25 million were living and working outside the country. Inequalities in economic opportunities across locations were among the primary drivers of this labor mobility: People in search of jobs or higher wages tend to move to places with greater opportunities. Proximity, communication, transport connectivity, and social networks are key enabling factors.

Migration offers a route to escape poverty and to achieve upward mobility. For some households, labor mobility is a survival strategy in response to adverse shocks. Other households and individuals can obtain more stable employment, diversify their incomes, and earn higher incomes if they choose to move within and outside Myanmar. Labor mobility can also increase incomes for migrant-sending families and communities through remittances. For some groups, particularly youth and women, labor mobility is linked to rising social aspirations for themselves and their families. Migration can also facilitate knowledge transfer, skills development, and a shift in gender norms-which leads to the empowerment of women. However, migration can also have negative consequences_for example, when migration is unsuccessful, when families are disrupted, or when integration and reintegration are difficult. 


\section{Main trends and issues in the Myanmar labor market ${ }^{1}$}

Myanmar's private sector is strengthening, in part through integration in the global economy. Special Economic Zones, the lifting of sanctions, and Myanmar's reintegration into the global economy support increased investment and firm activity-particularly in manufacturing, oil and gas, and services like telecoms and transport. Investment as a share of GDP increased by 6.5 percentage points in the past 5 years, and the number of registered private firms almost doubled between 2012 and 2015. Private investment, and particularly foreign direct investment, led the way.

Structural change is shifting economic activity toward higher value-added sectors, as it integrates into global value chains. Economic activity has shifted away from agriculture and toward manufacturing and services in recent years. Integration into the global economy is a key part of this shift. Myanmar is beginning to incorporate itself into Asian manufacturing value chains. Export values in the garment sector increased 2.5 times-from US $\$ 1$ billion in 2014-15 to US\$2.5 billion in 2017-18.

Myanmar's integration into the global economy is also reflected in job creation. The 2014 Enterprise Survey shows that the textile and garments sector employs the largest share of off-farm, nongovernment, nonmicroenterprise workers, and it was the most significant contributor to new job creation. At the same time, the country's growing consumer class is exerting greater demand, which has also resulted in new jobs. Hotels and restaurants and the retail and wholesale trade sectors are experiencing significant job growth, which is linked to burgeoning domestic and international tourism and business travel.

The private sector is primarily composed of small, young, urban firms. The 2015 Myanmar Business Survey found that nearly three-quarters of firms have five or fewer workers and that about 60 percent of firms were created after 2000. Mandalay and Yangon are home to about one-third of all of Myanmar's enterprises and more than half of its private sector workforce. Growth in services, in particular construction and hospitality, is concentrated in urban and periurban areas.

Private sector-led growth and job creation face significant challenges. Despite more integration with the global economy, Myanmar's links to global value chains are weaker than other countries. Only 1 percent of Myanmar enterprises are foreign-owned. These firms tend to employ more workers than domestic ones. The 2016 Enterprise Survey found that 5 percent of private enterprises in Myanmar were directly or indirectly involved in exporting, compared to 14 percent in Cambodia and 18 percent in Vietnam. Most domestic firms still operate in traditional activities, and their workforce is concentrated in these activities as well. According to the 2015 Myanmar Poverty and Living Conditions Survey (MPLCS), only 8 percent of the workforce works in large, registered firms. Wages are low, but so is labor productivity, which results in high unit labor costs.

These challenges result from a variety of constraints. The 2016 Enterprise Survey

1 This section draws on Cunningham and Muñoz (2018a), CSO, UNDP, and World Bank (2018), and World Bank (2019c). 
finds that firms cite access to finance, lack of an educated workforce, and access to land as the main obstacles. Other constraints include tax uncertainty, transport and logistics costs, customs procedures, as well as political uncertainty and weak state enforcement capacity. Small firms contend with limited managerial and professional skills and lack familiarity with relevant technologies.

The challenges and opportunities facing the private sector are reflected in Myanmar's labor force. Agricultural employment remains dominant in Myanmar, and work in the formal sector is infrequent. Many workers still contend with the seasonality of agricultural employment and seek alternative sources of income during the low season. However, the nascent progress to integrate Myanmar into the global economy is reflected in a parallel shift in jobs away from agriculture in recent years.

Unemployment rates in Myanmar are low for both men and women. The overall unemployment rate is 2.2 percent: 2.1 percent for men and 2.3 percent for women. However, there is a significant gender gap in the labor force participation rate. Myanmar's labor force consists of 21.7 million people, of whom 45 percent are women. The labor force participation rate overall is 62 percent, with a large gap between the female and male rates. Just over half of women participated in the labor force in 2017, compared to nearly three-fourths of men (Figure 1.1). One of the drivers of this dichotomy is women's disproportionate responsibility for domestic work: domestic work is the main activity for about a quarter of women but for less than 1 percent of men.

The education level of the workforce is low. Among the working-age population, nearly two-thirds of workers have only a primary school education or less, and just 20 percent have a high school education or more (Figure 1.2). This educational composition is changing somewhat. Younger workers between the ages of 15 and 24 are better educated than the workforce as a whole.

\section{Figure 1.1}

\section{Labor force participation rate in 2017}

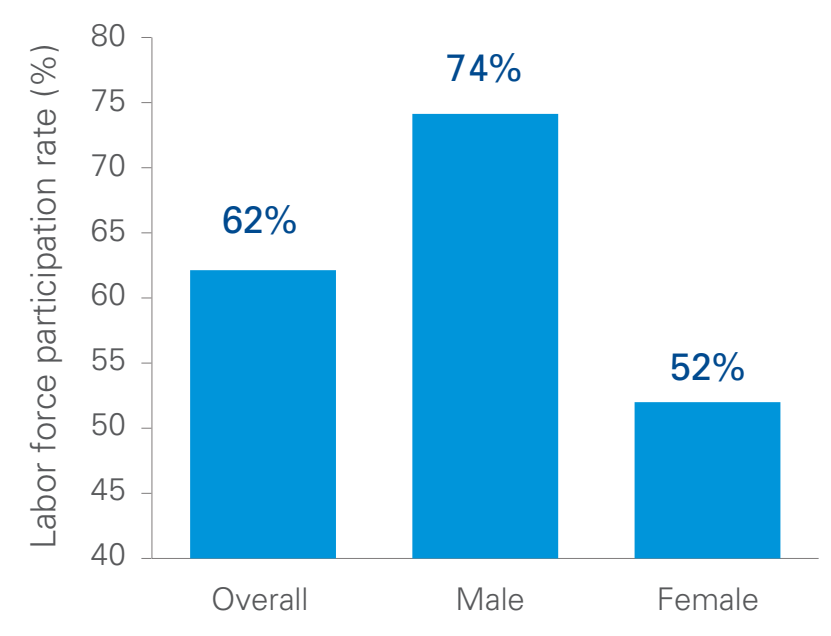

Source: CSO, UNDP, and World Bank 2018.

Figure 1.2

Education level of the workforce

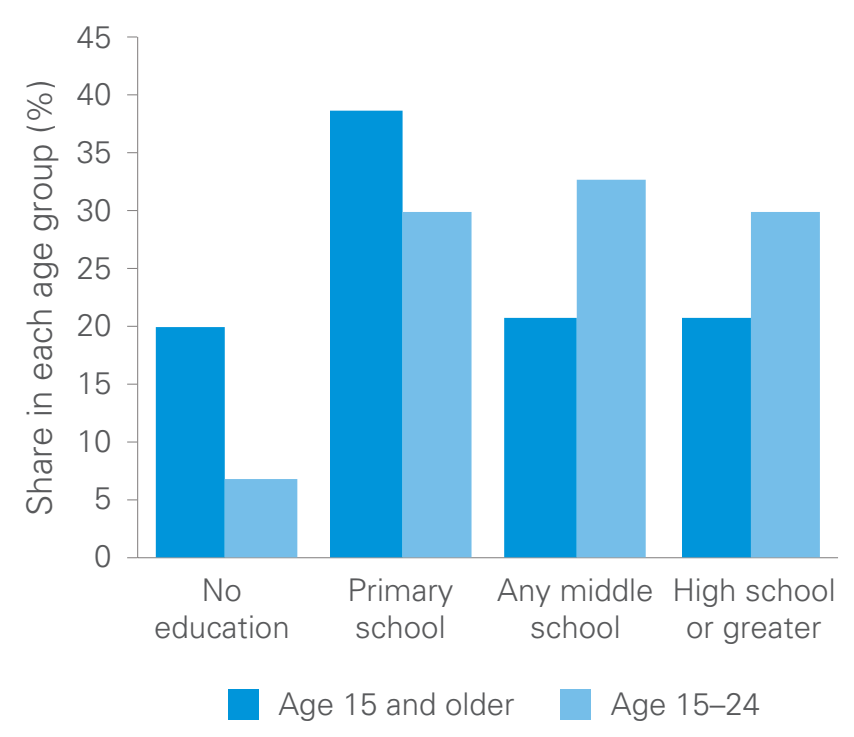

Source: Cunningham and Muñoz 2018a. 
Thirty-seven percent have a primary school education or less, and nearly a third have a high school education or more.

These low education levels translate into a predominance of low-skill jobs in low value-added sectors. Just 3 percent of the workforce is employed in highor mid-skill professions like managers, professionals, skilled technicians, or associate professionals. Nearly 40 percent are employed in unskilled jobs like street vending, building care and maintenance, security, or garbage collection. Nearly 30 percent undertake agricultural work for subsistence or sell agricultural outputs. Nearly half of workers are employed in low value-added sectors like agriculture, forestry, and fishing. This rate is more than 60 percent in rural areas. In urban areas, about a third of workers are employed in the wholesale and retail trade.

Casual work is common, and it pays less in Myanmar than in regional comparator countries. About one in five employees are casual wage workers, employed without

\section{Figure 1.3}

\section{The gender wage gap in Myanmar}

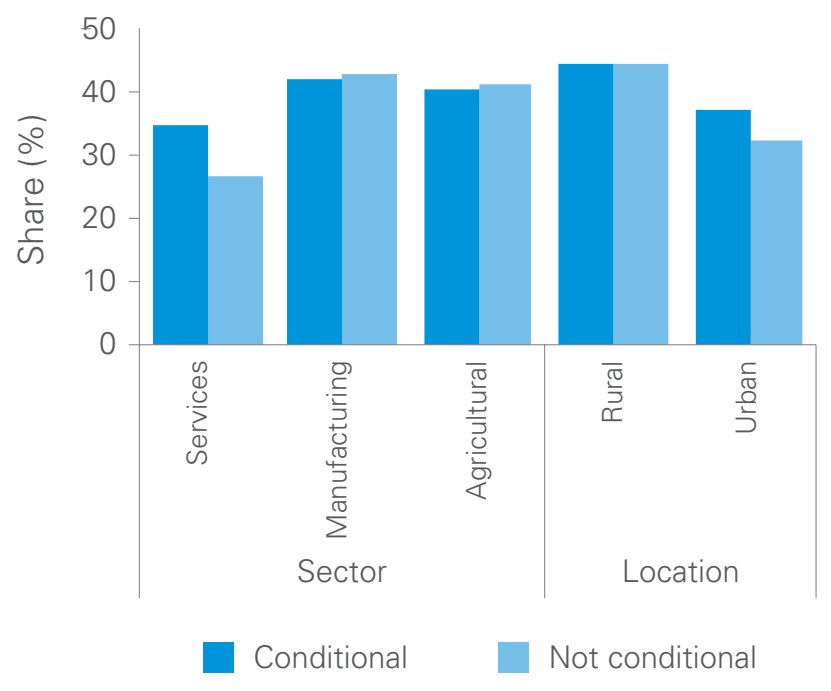

Source: Cunningham and Muñoz 2018a. a contract. About 60 percent of workers whose primary source of employment is in the agriculture sector work their own land, while 40 percent are wage laborers. These workers earn low wages compared to regional peers. Agricultural wage workers earn about US\$2 each day, while similar workers in Cambodia earn US\$4 and in China earn US\$18.

Many people work in low-quality jobs. Whether conditional on other worker characteristics or not, men earn between 30 and 45 percent more than women across economic sectors and urban and rural areas, with the largest gap seen in rural areas (Figure 1.3). Only about one-fifth of workers has a permanent wage job, and of these only about one-tenth has a contract, which translates into about 5 percent of the workforce having a contract. About a quarter of permanent wage workers-who tend be urban, younger, and more highly educated-has access to a pension; about a quarter has access to paid vacation; and about one-third has access to paid sick days. The remaining casual workers, and the nearly two-thirds of workers who own their own business on- or off-farm, face risks associated with uncertain income. Around a quarter of people work more than one job, with rural workers more likely to hold multiple jobs. Women, older people, and rural workers are more likely to have low-quality jobs, in which wages are about equal to the minimum wage.

Work varies significantly by season. Employment in Myanmar is highly seasonal, with a lean dry season in which agricultural work can be difficult to find. Indeed, about two-thirds of the days worked in cultivation are in the wet season, from June to October. Only about 17 days are worked in the dry season. The same pattern is true for agricultural casual work. Farm households need labor during the wet season, raising demand, but not during the dry season. 
Indeed, employment in agriculture in rural areas drops about 5 percentage points in the lean dry season (Figure 1.4). This is compensated in part by rises in employment in industry and services, which increase 2 percentage points and 3 percentage points, respectively. Women's work is more seasonal than men's. As a result of the seasonal nature of work in rural areas, sources of income vary for those rural households that rely on nonagricultural sources of income at certain times of the year, while urban incomes are stable throughout the year.

Despite the widespread work in agriculture and low-quality jobs, the labor market has evolved in recent years. First, labor force participation rates increased between 2005 and 2017. The increase was particularly notable for women: Their labor force participation rate increased from 48.9 percent in the $2004 \mathrm{cool}$ season to 54.8 percent in the $2017 \mathrm{cool}$ seasons. This is due to an increase in the share of women who are employed and a decline in those doing housework only. Second, women in rural areas are entering the workforce later and working for longer, which has resulted in more educated women in the workforce. Third, the share of workers in agriculture has declined since 2005, while the share in manufacturing and construction has increased. This trend is strongest for younger workers. Similarly, the proportion of households that rely only on income from nonagricultural sources is increasing in urban and rural areas.

The labor market in Myanmar faces several challenges, especially the lack of adequate education and skills. A survey of Myanmar employers found that more than 80 percent agree that the education system is not producing the level of skills or the up-to-date knowledge that is necessary for workers to perform their jobs (Rutkowski 2014). The 2017 Enterprise Survey found
Whether conditional on other worker

characteristics or not, men earn between 30 and 45 percent more than women across economic sectors and urban and rural areas, with the largest gap seen in rural areas.

that 4 of 10 hiring employers thought the workforce was inadequately educated. Despite the demand among employers for technical skills, few workers obtain technical training. As will be discussed in more detail later, the technical and vocational education and training system is fragmented and disconnected from the needs of the private sector. Ongoing conflict contributes to the employment challenges in Myanmar (Box 1.1).

\section{Figure 1.4}

Employment by sector in 2017

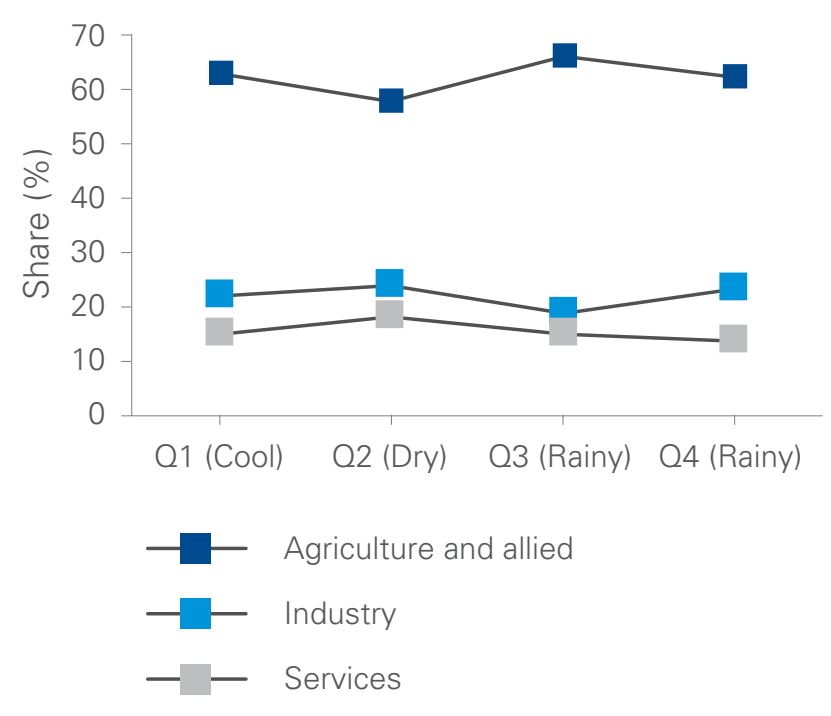

Source: CSO, UNDP, and World Bank 2018. 


\section{Box 1.1: Employment and conflict in Myanmar}

An additional challenge for job creation in some parts of Myanmar is civil conflict, which is ongoing. Subnational conflict impacts one-third of townships in the country, has resulted in the loss of thousands of lives, and cost valuable public resources. These conflict-affected areas tend to be disadvantaged: More than half of the population living in townships impacted by conflict are poor. Adult literacy and school enrollment are low, and these areas face significant challenges to create jobs. A range of factors can inhibit job creation in conflict-affected areas; these include a lack of functioning markets, weak institutions, weak connections to the larger economy, lack of investment due to uncertainty, and less asset ownership by households. At the same time, conflict-affected areas could gain the most from job creation, which can have benefits beyond employment by strengthening social cohesion and reducing violence. The Myanmar's Future Jobs report addresses the unique job challenges in conflict-affected areas; it recommends policy actions to provide short-term financing for households to accumulate assets and to develop micro industries that can be linked to existing markets.

Sources: World Bank 2019c; Cunningham and Muñoz 2018b.

Workers face difficulties accessing information about labor market trends and job openings. Most job searches are done informally through networking with friends and relatives: The 2015 MPLCS showed that more than 70 percent of jobseekers looked for jobs via family and friends, while only 1 percent responded to ads in newspapers, posters, or on the internet. Such informal searches limit both the type and location of job opportunities that jobseekers are exposed to. This in turn can mean that workers end up not working in jobs aligned with their skills and interests, or not working at all. Additionally, workers face challenges accessing the areas of economic activity, both inside and outside of Myanmar, where jobs are being created. Moving to Mandalay and Yangon, where wage jobs are concentrated, or to other countries where demand for workers is high, can involve significant costs. The next section discusses in detail the benefits and challenges associated with this mobility.

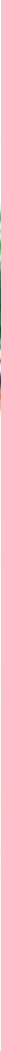




\section{Patterns of migration}

A large share of Myanmar's population is mobile. According to the 2014 Myanmar Population and Housing Census (hereafter referred to as "the Census"), approximately 11 million people (accounting for nearly a quarter of the population) reported that they had moved at least once in their lifetime ("lifetime migrants"). About 4.7 million (nearly 10 percent of the population) had moved from their usual place of residence in the five years preceding the Census ("recent migrants") (Table 1.1). More recent research shows that mobility remains an important aspect of life in Myanmar. The 2017 Capitalizing Human Mobility for Poverty Alleviation and Inclusive Development in Myanmar (CHIME) Survey in Ayeyarwady region, Mandalay region, Rakhine state, and Shan state found that nearly a quarter of households had at least one current migrant (Deshingkar, Litchfield, and Ting 2019). In Mandalay, as many as a third of households had a migrant, while 10 percent also had a member who had recently returned from migration.

\section{Table 1.1}

\section{Myanmar's migrant population in 2014}

\begin{tabular}{|c|c|c|c|c|c|c|}
\hline \multirow{2}{*}{ Migration } & \multicolumn{3}{|c|}{ Lifetime } & \multicolumn{3}{|c|}{ Recent } \\
\hline & Total & Males & Female & Total & Males & Females \\
\hline \multirow[t]{2}{*}{ Internal } & $9,231,619$ & $4,369,451$ & $4,862,168$ & $3,359,342$ & $1,609,146$ & $1,750,196$ \\
\hline & $(19.3 \%)$ & $(19.4 \%)$ & $(19.2 \%)$ & $(7 \%)$ & $(7.1 \%)$ & $(6.9 \%)$ \\
\hline \multirow{2}{*}{$\begin{array}{l}\text { Between townships } \\
\text { within districts }\end{array}$} & $2,687,677$ & $1,240,811$ & $1,446,866$ & 890,808 & 423,155 & 467,653 \\
\hline & $(5.6 \%)$ & $(5.5 \%)$ & $(5.7 \%)$ & $(1.9 \%)$ & $(1.9 \%)$ & $(1.8 \%)$ \\
\hline \multirow{2}{*}{$\begin{array}{l}\text { Between districts within } \\
\text { states and regions }\end{array}$} & $1,982,354$ & 930,074 & $1,052,280$ & 620,681 & 296,695 & 323,986 \\
\hline & $(4.1 \%)$ & $(4.1 \%)$ & $(4.1 \%)$ & $(1.8 \%)$ & $(1.3 \%)$ & $(1.3 \%)$ \\
\hline \multirow{2}{*}{$\begin{array}{l}\text { Between states and } \\
\text { regions }\end{array}$} & $4,561,588$ & $2,198,566$ & $2,363,022$ & $1,847,853$ & 889,296 & 958,557 \\
\hline & $(9.5 \%)$ & (9.8\%) & $(9.3 \%)$ & $(3.9 \%)$ & $(3.9 \%)$ & $(3.8 \%)$ \\
\hline \multirow[t]{2}{*}{ International } & $2,021,910$ & $1,233,168$ & 788,742 & $1,366,293$ & 842,684 & 523,609 \\
\hline & $(4.2 \%)$ & (5.5\%) & (3.1\%) & $(2.8 \%)$ & (3.7\%) & $(2.1 \%)$ \\
\hline \multirow[t]{2}{*}{ Total } & $11,253,529$ & $5,602,619$ & $5,650,910$ & $4,725,635$ & $2,451,830$ & $2,273,805$ \\
\hline & $(23.5 \%)$ & $(24.9 \%)$ & $(22.3 \%)$ & (9.9\%) & $(10.9 \%)$ & $(9.0 \%)$ \\
\hline
\end{tabular}

Note: The 2014 Myanmar Population and Housing Census is designed to capture long-duration migration. Lifetime migrants are defined as those persons who moved between townships at any time since their birth (including return migrants) as of 2014. Recent migration is defined as those persons who have moved residence in the five years prior to the Census (that is, between 2009-and 2014). A person must have resided at a place for a minimum of six months in the previous 12 months for it to be considered as the usual place of residence. Numbers in parentheses represent shares in total population, based on an estimated total population in conventional households (that is, excluding those enumerated in institutions) of 47,918,525.

Source: Department of Population 2016. 
Most of this migration is internal. According to the Census, more than 70 percent of recent migrants relocated internally within Myanmar, while the rest had moved out of the country. Among internal migrants, more than half moved across states or regions, about 18 percent moved between districts within states or regions, and the remaining 26 percent moved between townships within districts. ${ }^{2}$ Again, the prominence of internal migration has been confirmed by other sources. The 2017 Myanmar Living Conditions Survey (MLCS) shows that almost 18 percent of the population in 2017 had moved townships within Myanmar at least once in their lifetime (World Bank 2019b). Just over 5 percent of the population had moved residences within Myanmar in the last 5 years (between 2012 and 2017). The CHIME survey found that 74 percent of all migrants had moved within Myanmar (Deshingkar, Litchfield, and Ting 2019). Internal migration is linked to an ongoing process of urbanization in Myanmar (Box 1.2).

\section{Box 1.2 Migration and urbanization in Myanmar}

Migration and urbanization are interlinked in Myanmar. Although the country started at a relatively low level of urbanization, a projected 35 percent of the population is expected to live in urban areas by 2050. Of this population, an estimated increase of 9 million people in cities is expected due to migration alone. Increasing urbanization is already putting a severe strain on urban infrastructure and services, especially in Yangon-the most common destination for internal migrants and the most urbanized region-with nearly 35 percent of the country's urban population (Department of Population 2016; World Bank 2019a).

Urban migrants face underemployment and unstable earnings. Although migrants are moving to industrial zones, not all find regular jobs in factories, many of which require minimum education qualifications or impose age or health restrictions (Forbes 2019). Instead, most employment is generated by informal settlements with many migrants selling goods and services to one another while others seek service jobs as domestic workers or security guards in nearby middle-class neighborhoods (Forbes 2019). Qualitative research also highlights the vulnerability of irregular working hours, employers' practice of withholding pay, and difficult and exploitative working conditions (including cases of bonded labor) (Deshingkar, Litchfield, and Ting 2019).

New arrivals face the challenge of finding affordable housing in the city. Urban migrants typically live in informal settlements with insecure tenures, threats of eviction, lack of basic services, crowded and poor environmental health conditions, exposure to natural and industrial hazards, and crime and violence (ILO 2015a; Kyed 2017; Forbes 2019).

Some migrants cannot afford existing housing and construct poor quality shelters out of basic materials in poor neighborhoods. These include shelters near work sites, in urban peripheries, or in fields or forests outside villages in rural areas. These informal settlers and squatters face the constant threat of eviction because informal settlements are considered illegitimate and undesirable by authorities and local residents. They also lack access to basic services such as electricity, water, and sanitation. (ILO 2015a; Kyed 2017; Than Pale 2018; World Bank and CESD 2018; Forbes 2019).

Source: Authors. 


\section{Migration corridors}

Internal migrants move across and within Myanmar states and regions. In 2014, the geographic areas with the highest internal outmigration were the Delta and the Dry Zone. Ayeyarwady and Bago (in the Delta) and Magway (in the Dry Zone) had the highest out-migration rates, likely driven by high poverty and underemployment, combined with proximity to growth centers like Mandalay and Yangon (Table 1.2). States and regions with high inmigration rates were Kachin, Kayin, Nay Pyi Taw, and Yangon. Many internal migrants also moved to other townships within a state or region. For instance, of the 564,580 recent migrants from Ayeyarwady, 23 percent moved within the region (Department of Population 2016)

Yangon is by far the most popular destination for internal migrants due to its relatively high employment demand and higher local wages. Between 2009 and 2014, 116 people arrived in Yangon

Table 1.2

Migration rates for recent internal migration by agro-ecological zones in 2014 Per 1,000 people

\begin{tabular}{|c|c|c|c|}
\hline Total & Inmigration rate & Outmigration rate & Net migration rate \\
\hline \multicolumn{4}{|c|}{ Hills and Mountains } \\
\hline Chin & 13.1 & 47.9 & -34.7 \\
\hline Kachin & 54.9 & 32.1 & 22.8 \\
\hline Kayah & 49.9 & 29.4 & 20.6 \\
\hline Kayin & 58.3 & 15.2 & 43.1 \\
\hline Shan & 27.3 & 16.0 & 11.3 \\
\hline \multicolumn{4}{|c|}{ Dry zone } \\
\hline Magway & 11.1 & 51.3 & -40.2 \\
\hline Mandalay & 36.5 & 33.9 & 2.6 \\
\hline Nay Pyi Taw & 103.9 & 44.2 & 59.9 \\
\hline Sagaing & 14.1 & 30.1 & -16.0 \\
\hline \multicolumn{4}{|c|}{ Delta/coastal } \\
\hline Ayeyarwady & 7.9 & 73.0 & -65.0 \\
\hline Bago & 18.1 & 52.9 & -34.9 \\
\hline Mon & 35.4 & 37.7 & -2.2 \\
\hline Rakhine & 9.1 & 39.8 & -30.6 \\
\hline Yangon & 116.4 & 23.5 & 93.0 \\
\hline Tanintharyi & 34.9 & 19.2 & 15.7 \\
\hline
\end{tabular}

Source: Department of Population 2016.

3 Due to the non-enumeration of a large segment of the population, internal migration patterns for Rakhine are difficult to ascertain (Department of Population 2016). 
for every 1,000 existing residents. The 2017 Myanmar Living Conditions Survey (MLCS) shows that 45 percent of internal migrants live in Yangon (World Bank 2019b). Qualitative research and household surveys corroborate this finding. For instance, CHIME survey found that 36 percent of internal migrants reported moving to Yangon (Deshingkar, Litchfield, and Ting 2019). A 2013-14 survey of formal sector workers registered with the Social Security Board found that about 53 percent of registered formal sector workers in Yangon were migrants (Griffiths 2016). Among all the migrants in the sample, about 43 percent were from Ayeyarwady. These migration flows are consistent with the relative size of the formal sector, which is substantially larger in Yangon relative to other parts of the country.

There are several large migration corridors within Myanmar. Based on data from the 2017 MLCS, many of the 10 largest migration corridors flow to Yangon, including the largest from Ayeyarwady to Yangon (Maps 1.1 and 1.2). This reflects the large number of men moving to work in Yangon's industrial zones and service sectors, and women moving to work in garment factories and the services sector. Other large migration corridors include flows from the Delta (Bago and Rakhine) and Dry Zone (Magway) to Yangon; within the Dry Zone (from Sagaing to Mandalay); and from the Dry Zone to border states (Mandalay to Shan). Migration from Mandalay to Yangon has declined recently (World Bank 2019b). The choice of destination is likely a function of proximity, perceived availability of economic opportunities, and the strength of social networks (Pattison et al. 2016b; Deshingkar, Litchfield, and Ting 2019).

\author{
Yangon is by far the most \\ popular destination for \\ internal migrants due \\ to its relatively high \\ employment demand \\ and higher local wages. \\ Between 2009 and 2014, \\ 116 people arrived in \\ Yangon for every 1,000 \\ existing residents.
}

At the national level, most internal migration is within urban areas. According to the 2017 MLCS, about 47 percent of recent ${ }^{5}$ migrants moved within urban areas (Figure 1.5). Urban-urban flows reflect movement from small towns to larger towns and cities that offer more employment opportunities and amenities, and perhaps easier physical mobility within urban areas. Additionally, the large size of metropolitan boundaries in Myanmar implies that considerable migration takes place between smaller administrative areas within large metropolises such as Mandalay and Yangon where most jobs, both in manufacturing and services, are concentrated (Figure 1.5and Nyi Nyi 2013). ${ }^{6}$ Rural-to-urban flows accounted for only 10 percent of all internal migration, most commonly across states and regions. This is expected to increase as Myanmar urbanizes more rapidly (World Bank 2019a).

\footnotetext{
$4 \quad$ These workers comprise approximately 2 percent of the labor force.

5 "Recent" refers to people who have moved at any point in the 5 years preceding the survey.

For instance, a small but significant proportion of migrants in Yangon are squatters moved by the government from the inner city to the peripheral townships in the 1990s and central Yangon residents driven to peripheral townships by rapidly rising rents and the cost of living (Forbes 2019).
} 
Map 1.1

Top 10 migration corridors for lifetime migrants within Myanmar
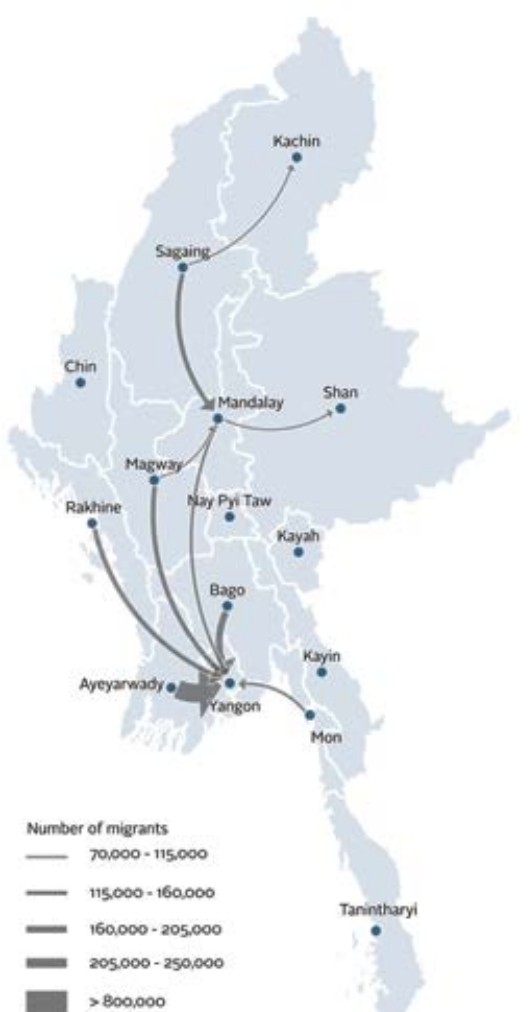

Note: Arrows are weighted by the number of migrants and show the direction of migration across states and regions.

Source: World Bank 2019b.

\section{Map 1.2}

\section{Top 10 migration corridors for recent} migrants within Myanmar
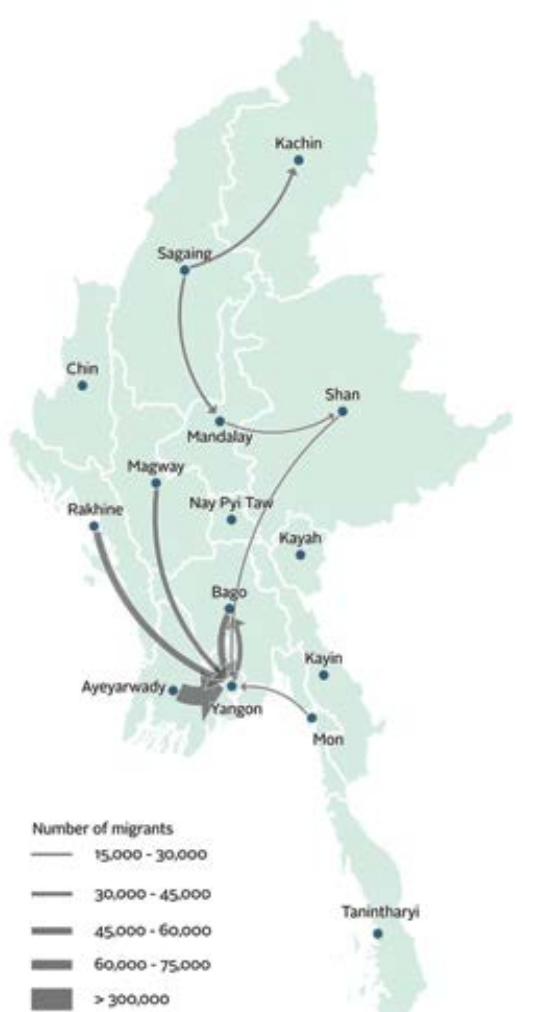

Note: Arrows are weighted by the number of migrants and show the direction of migration across states and regions.

Source: World Bank 2019b.

\section{Figure 1.5}

Migration flows between 2009 and 2014 in selected states and regions

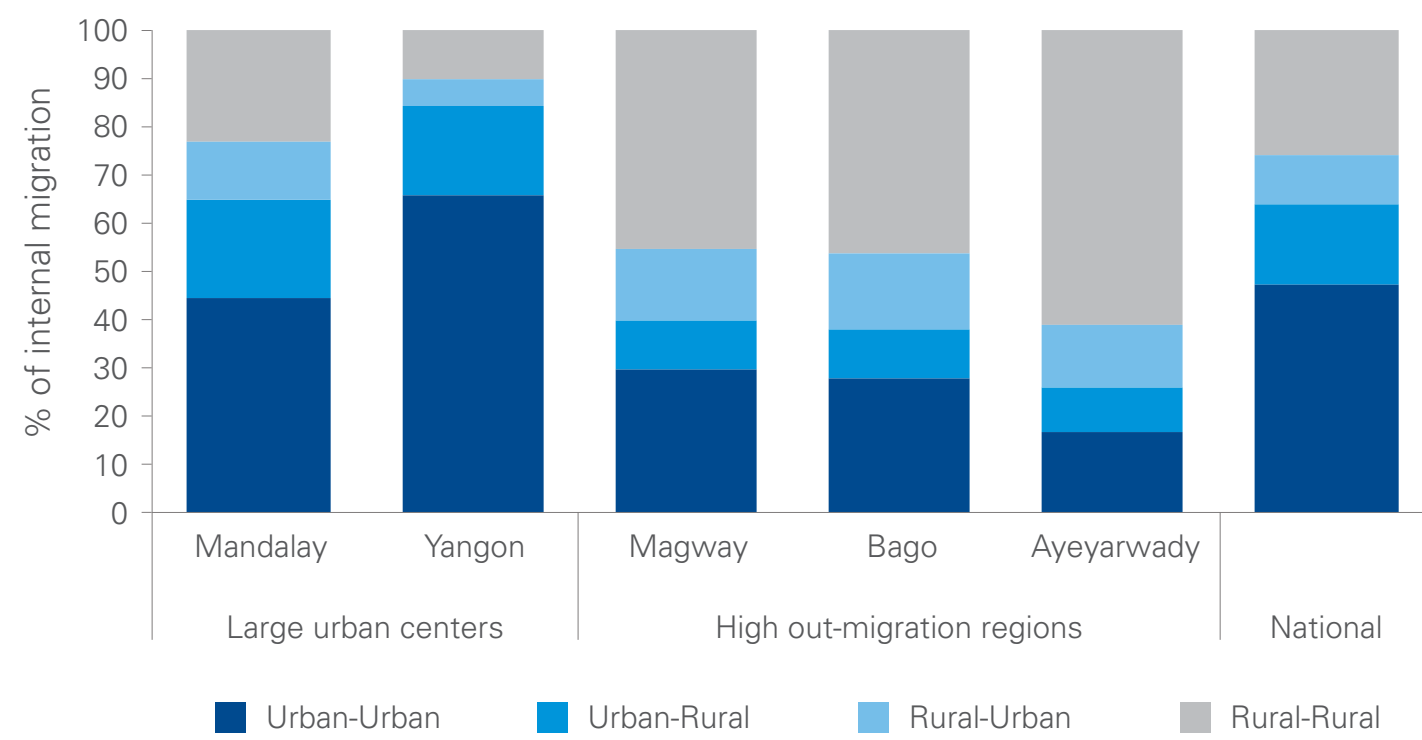


A large proportion of internal migrantsabout 26 percent-moved within rural areas. The rural-rural flows reflect movement of agricultural workers from areas with high underemployment and low wages to more agriculturally prosperous areas or to areas with natural resources. Migrant surveys and qualitative studies identify some of these internal migration corridors: They include, for example, traditional routes from rural Ayeyarwady, Magway, and Sagaing to tea plantations in Shan, and to rubber and other cash crop plantations in the Southeast; seasonal movements from rural Magway to oil seed processing factories in Magway city; and from Rakhine to jade mines in Kachin. Emerging routes include people moving from the Dry Zone to sugarcane plantations along the Chinese border (ILO 2015a; Maharajan and Myint 2015; World Bank and CESD 2018).

Step migration is prevalent along Myanmar's border with China and Thailand. Shan and states in the Southeast (especially Mon and Kayin, but also Tanintharyi) are step migration states. Many migrant workers from the Delta and Dry Zone migrate in two stages, first to work in the border states of the country, and then to cross the border for work. Migrants from Ayeyarwady and Rakhine often use Mon and Kayin states as a transit point for migration to Thailand, because the cost of migration is lowest along this route; and migrants from the Dry Zone often use Shan for migration to Thailand and China. A survey of aspirant international migrants in three states or regions found the ethnicity of aspirant migrants in Mandalay and Shan reflected the local population; there was more diversity in Tanintharyi with 15 percent Bamar (likely internal migrants from the Delta and Dry Zone) as well as the local Dawei (74 percent) and Kayin (11 percent) (ILO 2015b).
Figure 1.6

\section{International migrants by country of} destination

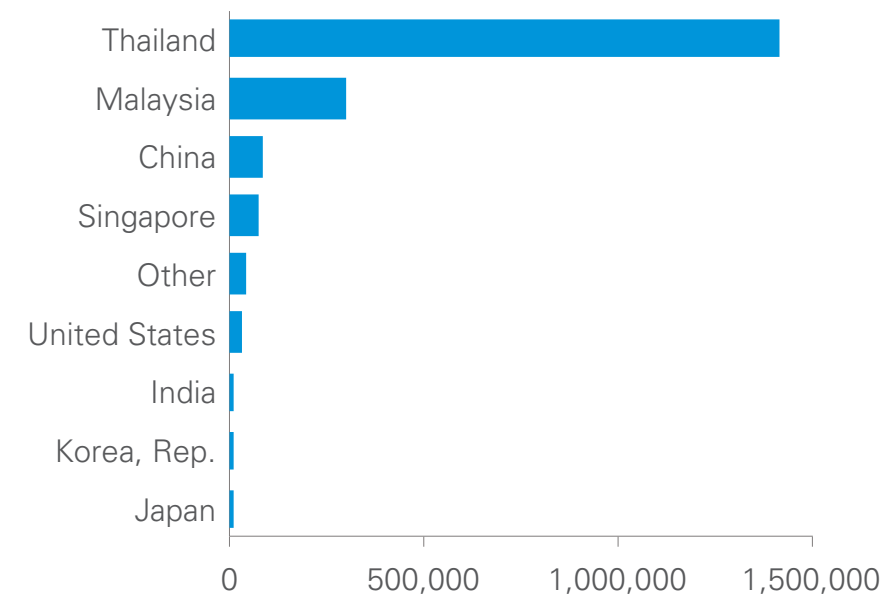

Source: Department of Population 2016.

International migration from Myanmar is concentrated in four main Southeast Asian destinations, with Thailand by far the most popular. Myanmar is one of the top 15 countries of origin of migrants in the Asia-Pacific region, (UN ESCAP 2017). In 2014, the vast majority (70 percent) of Myanmar's international migrants moved to Thailand, and another 15 percent to Malaysia (Figure 1.6). The MyanmarThailand corridor is the largest in Southeast Asia, with Myanmar migrants accounting for 53 percent of Thailand's migrants, and 29 percent of all migrants within the Association of Southeast Asian Nations (ASEAN) (Testaverde et al. 2017). However, other destinations have gained importance in recent years, notably China, the Republic of Korea, and Singapore (Ma 2017; World Bank and CESD 2018).

The states and regions sharing a border with China and Thailand account for the bulk of Myanmar's international migration. In 2014, about two-thirds (50 percent of male and 75 percent of female) international migrants originated from Mon, Kayin, Shan, and Tanintharyi states (Figure 1.7). Recent 
Figure 1.7

International migrants by state/region of origin

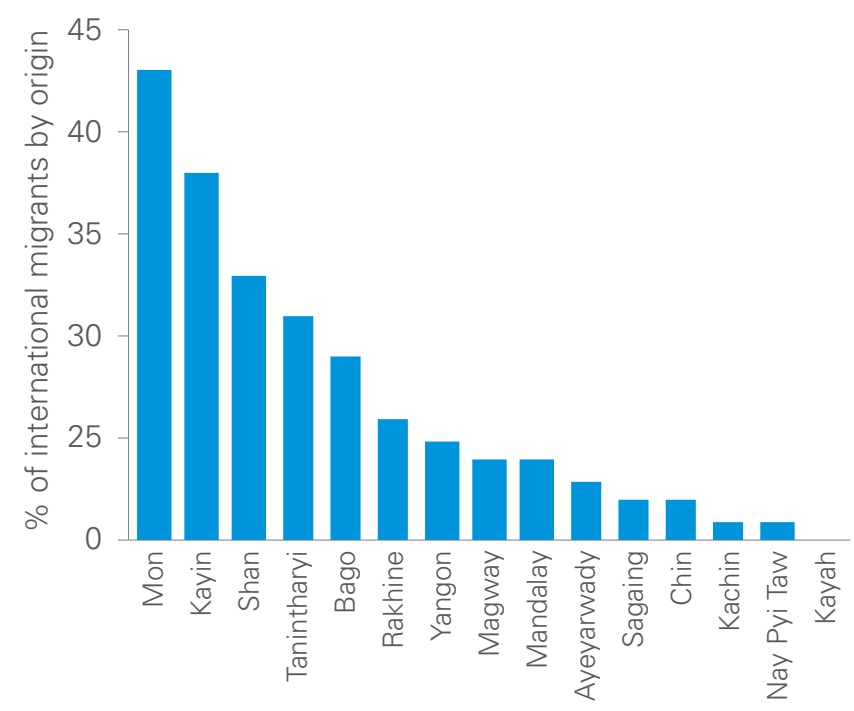

Source: Department of Population 2016.

studies of migration to Thailand highlight the growing share of migrants from Bago and Magway (IOM 2019). There is also some evidence of seasonal cross-border migration; for instance, a study in the Dry Zone found instances of landless and small farmer households in Shan migrating across the border to China for farm work during Myanmar's lean agricultural season (Maharajan and Myint 2015). Another study found that in 2018, a substantial share of migrants moved across the border into Tak province in Thailand for seasonal or daily work (IOM 2019).

\section{Migrant characteristics}

Both internal and international migrants are younger than the population as a whole. The 2014 Census found that recent migrants are concentrated in the age group of 15- to 29-year-olds, with women typically even younger, in the age group of 15- to 24-year-olds. The 2015 MPLCS corroborates this finding (Figure 1.8), as does the 2017 MLCS, which shows that early adulthood is the prime age for internal migration (World Bank 2019b). Most internal migrants in an ILO survey conducted in 14 states and regions were between the ages of 18 and 20 (16 percent), 21 and 30 (41 percent), and 31 and 40 (20 percent) (ILO 2015a). Fieldwork undertaken by the World Bank and CESD in Ayeyarwady and the Dry Zone, found that employers in the garment sector in Yangon preferred to hire younger women (World Bank and CESD 2018). Most aspirant international migrants surveyed by the ILO in three states and regions fell between the ages of 18 and 24 ( 55 percent) and 25 and 30 (22 percent) (ILO 2015b). Migrant surveys also find that Myanmar migrants to Malaysia and Thailand, especially female migrants, tend to migrate at very young ages. There is some evidence of underage migration, either to join family or to become domestic workers (Department of Population 2016; Harkins, Lindgren, and Suravoranon 2017).

Migrants are more likely to be married than the nonmigrant adult population. Between 45 and 49 percent of recent $^{7}$ internal migrants were married, and marriage is more likely for those moving between states and regions, compared to those moving shorter distances within states and regions (Department of Population 2016). The 2017 MLCS shows that internal migrants who moved at any point in their lifetime are more likely to be married than nonmigrants, and also that migration tends to be done jointly: about 60 percent of these migrants moved at the same time as at least one other current household member (World Bank 2019b). Migrant surveys in Thailand found that a large number of international migrants have their spouses with them (an estimated 41 percent in a 2012 survey) (Chantavanich and Vungsiriphisal 2012).

7 As for the MLCS, "recent" refers to migrants who moved at any point in the 5 years preceding the survey. 
The extent of mobility within Myanmar is similar for men and women, but far more men migrate internationally compared to women. Women constitute about 55 percent of Myanmar's population, and they account for about 52 percent and 38 percent of recent internal migrants and international migrants, respectively (Department of Population 2016). ${ }^{8}$ Previous surveys by the Department of Population confirm that both men and women have been moving within Myanmar at about the same rate, with men constituting 48 percent of internal migrants who migrated at any point in their lifetime by 1991, and 46 percent by 2007 (Nyi Nyi 2013). Some studies point to a growing feminization of migration, at least from some parts of Myanmar. For example, more women than men migrate from Shan and from Ayeyarwady to Yangon (Department of Population 2016; Deshingkar, Litchfield, and Ting 2019).

Migrants tend to have more education. Like the Myanmar population, most migrants have completed primary education. But recent internal migrants (especially those moving within urban areas) and international migrants are more likely to have completed middle or higher education, relative to the adult population (Figure 1.9). This finding is corroborated by the 2017 MLCS and migrant surveys in Thailand (Harkins, Lindgren, and Suravoranon 2017; IOM 2019; World Bank 2019b).

Migrants are more likely to be employed than the nonmigrant working-age population, especially in nonagricultural work. Nearly all international migrants and around 90 percent of internal migrants work, compared with just 62 percent of the nonmigrant working-age population (Cunningham and Muñoz 2018a). In 2014,
Figure 1.8

Age profile of migrants and the working-age population

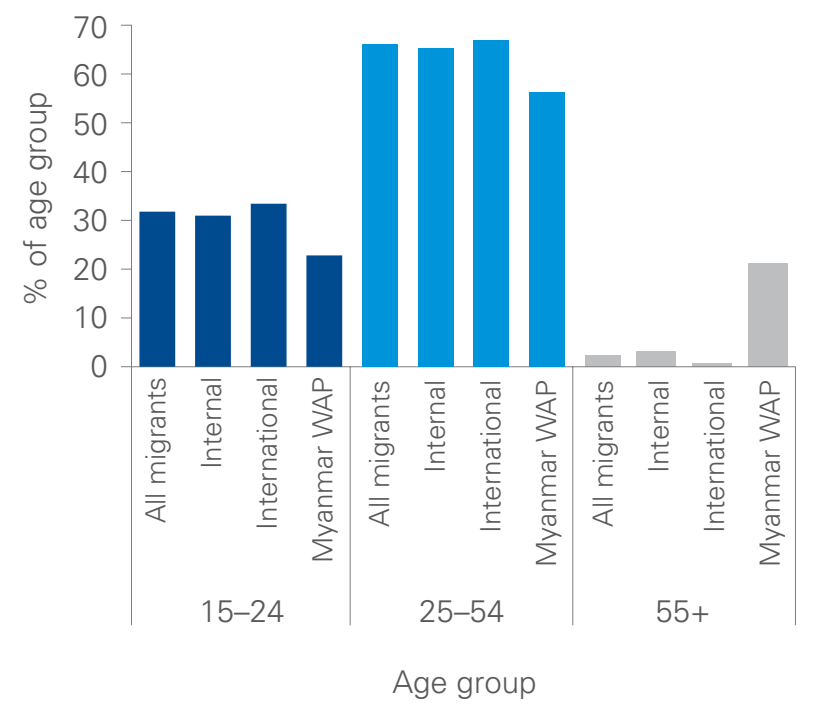

Note: WAP = working-age population.

Source: Cunningham and Muñoz 2018a.

\section{Figure 1.9}

Education profile of migrants and the working-age population

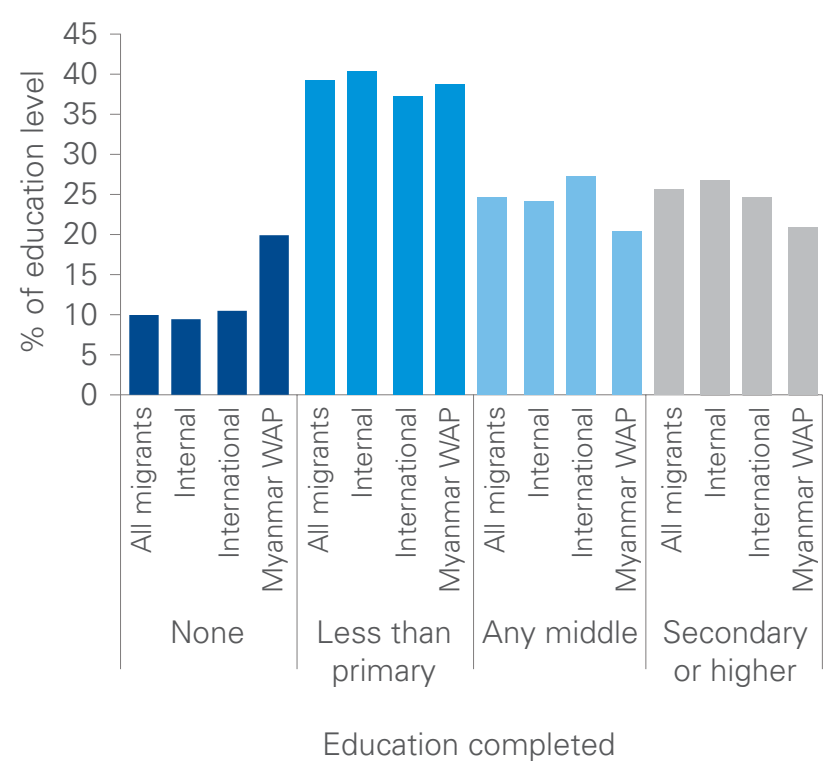

Note: WAP = working-age population. Source: Cunningham and Muñoz 2018a.

8 The ILO surveys of internal migrants in 14 states/regions and of aspirant international migrants in three states/regions found that twothirds of respondents were male, partly due to data collection constraints for female migrants (ILO 2015a and 2015b). 
only about 22 percent of recent internal migrants were employed in agriculture (relative to 62 percent of the nonmigrant population), while the majority were employed in manufacturing and services (construction, transport, trade, hotel, and food) (Department of Population 2016). Similarly, the 2017 MLCS showed that 63 percent of internal migrants were members of households employed only in nonagricultural work, relative to 29 percent of nonmigrants (World Bank 2019b).

\section{Temporary migration}

Temporary migrants are people who move temporarily away from their household. ${ }^{9}$ The previous sections focus on migrants that move away from their homes for longer than a year. This section focuses specifically on temporary migrants. Unlike the 2014 Census, the 2017 MLCS provides data on this group. The 2017 MLCS defines temporary migrants as individuals who have been temporarily absent from their household residence for at least one month in the past 12 months due to work or the search for work in Myanmar, or abroad (temporary economic migrants), or due to education, health, visiting a family member, or other noneconomic reasons (temporary noneconomic migrants).

Most temporary migrants are economic migrants. Overall, 8 percent of the Myanmar population in 2017 were temporary migrants. Sixty percent of temporary migrants are economic ones, and the rest are noneconomic migrants. Most temporary economic migrants work in Myanmar (87 percent), while 12 percent are working abroad, and 2 percent are looking for work (Table 1.3). Most temporary noneconomic migrants are away from home for education. In fact, temporary noneconomic migration increases significantly at ages 14 and 15-the ages at which many students enter high schools-which tend to be more difficult to access than primary or middle

\section{Table 1.3}

Reasons for temporary economic and non-economic migration

Percent

\begin{tabular}{|c|c|c|c|c|c|c|c|}
\hline & Union & Urban & Rural & Female & Male & Poor & Non-poor \\
\hline \multicolumn{8}{|c|}{ Economic migrants } \\
\hline Work in Myanmar & 87 & 82 & 88 & 87 & 86 & 89 & 85 \\
\hline Work abroad & 12 & 16 & 11 & 11 & 12 & 9 & 13 \\
\hline Looking for work & 2 & 2 & 1 & 3 & 1 & 2 & 2 \\
\hline Total & 100 & 100 & 100 & 100 & 100 & 100 & 100 \\
\hline \multicolumn{8}{|c|}{ Noneconomic migrants } \\
\hline Education & 54 & 41 & 59 & 51 & 58 & 52 & 54 \\
\hline Health & 8 & 9 & 8 & 9 & 5 & 5 & 9 \\
\hline Other & 38 & 50 & 34 & 40 & 35 & 43 & 37 \\
\hline Total & 100 & 100 & 100 & 100 & 100 & 100 & 100 \\
\hline
\end{tabular}

Source: World Bank 2019b.

9 This section draws from World Bank (2019b). 
schools. This noneconomic migration declines at age 20, while temporary economic migration increases significantly between the ages of 15 and 20, before declining gradually to age 60. Temporary noneconomic migration rises after age 60 because of health reasons or family.

Temporary economic migration is three times more likely among men than women, while rates are similar for temporary noneconomic migration. Nearly threequarters of all economic migrants are men. This is consistent with women's lower labor force participation rates and greater participation in housework and household enterprises. Temporary economic migration is more common among rural than urban residents. Rural residents are more likely to migrate within Myanmar, and urban residents are more likely to migrate abroad (Table 1.3). Rural residents who migrate for noneconomic reasons are more likely to migrate for education than urban residents.

Temporary migration varies significantly across states. Bago has the largest share of temporary migrants, followed by Tanintharyi and Rakhine. Bago, Kachin, and Tanintharyi have the largest share of temporary economic migrants. While temporary economic migration for work within Myanmar is more significant than migration for work outside Myanmar across all states, rates of temporary migration for work abroad tend to be higher in the border states. Notably, this is not true for Kayin, Chin, and Mon, which are along the border with Thailand, where permanent or longerterm migration is more prevalent.

Temporary economic migrants tend to be poorer than noneconomic migrants. Wealthier individuals are more than twice as likely as poorer individuals to be noneconomic migrants-however, the relationship between welfare and economic migration is complex. The share of temporary economic migrants who migrate within Myanmar decreases with wealth, while the share who migrate abroad increases with wealth, likely reflecting the more significant cost of overseas migration that only the wealthy can afford (Table 1.3).

Temporary economic migrants do different jobs than employed people who are not economic migrants. Temporary economic migrants are more likely than employed people who are not economic migrants to have more than one job, and to work in unskilled occupations, such as casual labor in mining, construction, manufacturing, or refuse collection. Temporary economic migrants are also more likely to work outside of the agricultural sector: 54 percent of employed people who are not economic migrants work in agriculture, compared to 37 percent of temporary economic migrants working in Myanmar, and 27 percent working abroad. These migrants instead tend to work in industry as unskilled laborers in construction or manufacturing.

Temporary migration is a diversification strategy for some households. Households that split their work between agriculture and nonagriculture are twice as likely to migrate as households engaged exclusively in agriculture or exclusively in nonagriculture. This suggests the importance for some households of using temporary migration to engage in nonagriculture work. 


\section{Drivers of migration}

Spatial inequalities in economic opportunities are primary drivers of economic migration. People in search of jobs or higher wages tend to move to places with greater opportunities. The concentration of economic activity and jobs in a relatively small number of urban areas within Myanmar, and the higher wages available abroad, motivate people to migrate internally and internationally.

Although Myanmar has made substantial economic progress in the last decade, there are still wide spatial disparities in living standards between rural and urban areas and across states and regions. In 2017, 30 percent of rural households were poor compared to only 11 percent of urban households (CSO, UNDP, and World Bank 2019). Indeed, 87 percent of Myanmar's poor live in rural areas. There are also stark geographic differences: 57 percent of the poor live in the Delta and the Dry Zone. GDP per capita ranges from MMK 737,000 (US\$542) in Chin to MMK 2.8 million (US\$2,068) in Yangon.

Nearly two-thirds of households continue to rely on the low incomes and seasonal employment that characterize the agriculture sector. Despite rapid growth in recent years, more than half of the labor force works primarily in agriculture, either on family farms or as agricultural wage workers (CSO, UNDP, and World Bank 2018). This agricultural employment is highly seasonal. About two-thirds of days worked in cultivation are in the wet season from June to October. Only about 17 days are worked in the dry season. Farming households also face the challenge of low productivity and fluctuating prices, compounded by extreme weather conditions. This contributes to low incomes for farming households as well as for agricultural labor. And not all rural areas are equal. Some offer more employment opportunities at higher wages-for instance, in plantation farming, possibly because of the labor shortages created by international migration.

As described above, jobs are concentrated in a few urban growth centers in Myanmar. With the opening of the economy, manufacturing sectors, such as garments, have grown significantly (World Bank 2019c). Several industrial zones have been created in recent years; Yangon alone has 23 industrial zones, which are concentrated in two of the districts that receive the highest number of internal migrants. ${ }^{10}$ Most manufacturing jobs are found in urban areas, but half of them are in just two urban centers, Mandalay and Yangon. Similarly, the recent growth in services, particularly the construction and hospitality sectors, has been concentrated in urban and periurban areas (Cunningham and Muñoz 2018a).

Compared to the domestic economy, Myanmar's neighbors offer greater employment opportunities and higher earnings. The GDP per capita of the two main destinations for Myanmar's international migrants-Malaysia and Thailand-is 5.1 and 3.1 times higher than in Myanmar, respectively, an indication that workers in those countries earn more. Many ASEAN countries are rapidly aging, leading to labor shortages and an increasing demand for young migrant workers to compensate for the shrinking labor force (ADB 2013; Testaverde et al. 2017).

10 There are three industrial zones each in Mandalay and Ayeyarwady, two each in Bago and Magway, and one each in Sagaing, Mon, Shan, and Tanintharyi (Department of Population 2016). 
Proximity also influences international labor mobility. Long and porous borders, combined with shared languages and ethnicity, have long facilitated movement along the Myanmar-Thailand and the Myanmar-China borders (ADB 2013; Department of Population 2016). Myanmar and Thailand share about 400 official entry points and many more unofficial crossings (Thanasombat 2004). The development of economic corridors, urbanization of the border areas, and special economic zones along some parts of the border have also facilitated international migration.

The recent transformation in communication and transport connectivity has facilitated both internal and international migration. The price of SIM cards fell from 1.5 million kyat in 2004 to 1,500 kyat in 2014 (CSO, UNDP, and World Bank 2018). Nearly 82 percent of households owned at least one mobile phone in 2017 (compared to only 0.4 percent in 2005), while nearly a quarter of the population ages 15 and above had used the internet in the week preceding the survey. Among mobile phone owners, smartphones dominate, particularly in urban areas. The rapid adoption of mobile phones and the internet facilitate mobility in two ways: First, by facilitating the spread of information increased connectivity shapes the aspirations of rural youth and reduces the cost of searching for a job. Second, by making it easier for migrants to stay in touch with their families and communities connectivity mitigates concerns about security and family disruption. Improvements in transport also play a role. Air and road networks facilitate movement between states and regions and between countries.

Overall, migration is motivated by a variety of economic and social push-and-pull factors. Migration provides a potential route to escape poverty by stabilizing, increasing, and/or diversifying household incomes. In some cases, households seek out opportunities in other locations because of negative shocks (push factors). This is particularly true for households with subsistence constraints for whom labor mobility becomes a survival strategy

\section{Table 1.4}

\section{Drivers of labor migration in Myanmar}

\begin{tabular}{l|l}
\multicolumn{1}{c}{ Driver } & \multicolumn{1}{c}{ Profile } \\
$\begin{array}{l}\text { Job opportunities and } \\
\text { income diversification }\end{array}$ & $\begin{array}{l}\text { Internal migrants who are unemployed or under-employed and move to urban or } \\
\text { more dynamic rural areas that offer jobs during the lean season, or more stable } \\
\text { jobs throughout the year, but not necessarily significantly higher wages. }\end{array}$ \\
\hline Higher earnings & $\begin{array}{l}\text { Internal migrants to urban areas and international migrants who move in search } \\
\text { of employment opportunities with higher earning potential. }\end{array}$ \\
\hline Social aspirations & $\begin{array}{l}\text { Internal migrants (especially youth) to urban areas and international migrants } \\
\text { who move in search of better working and living conditions, better access to } \\
\text { services, and/or an improved quality of life. } \\
\text { Social aspirations }\end{array}$ \\
\hline Internal migrants (especially youth) to urban areas and international migrants \\
who move in search of better working and living conditions, better access to \\
services, and/or an improved quality of life.
\end{tabular}

Sources: Pattison et al. 2016a; Jampaklay and Kittysuksathit 2009; Chantavanich and Vungsiriphisal 2012; ILO (2015a, 2015b); IOM and ARCM 2015; Maharajan and Myint 2015; Saw Yu May 2015; Gupta 2016; Kyan Htoo and Aye Myintzu 2016; Harkins, Lindgren, and Suravoranon 2017; and World Bank and CESD 2018. 
after job loss, natural disaster, and conflict. Labor mobility is also linked to perceived opportunities for more stable or betterpaying jobs and to rising social aspirations (pull factors). This is particularly the case for youth and women, and for those living in areas with a history of migration. These drivers can operate in unison. For instance, rural youth may choose to move to urban areas in search of more stable employment, higher earnings, and an urban lifestyle. Table 1.4 provides a summary of the key drivers of migration in Myanmar.

A significant share of internal migrants, particularly men, cite employment or the search for employment as the main reason for migration. Nearly half of recent male migrants and more than a quarter of recent female migrants moved for work between 2009 and 2014 (Figure 1.10). It is highly likely that those citing "followed family" are actually joining another economic migrant. If this is indeed the case, the

\section{Figure 1.10}

Motivation for internal migration by gender, 2009-14

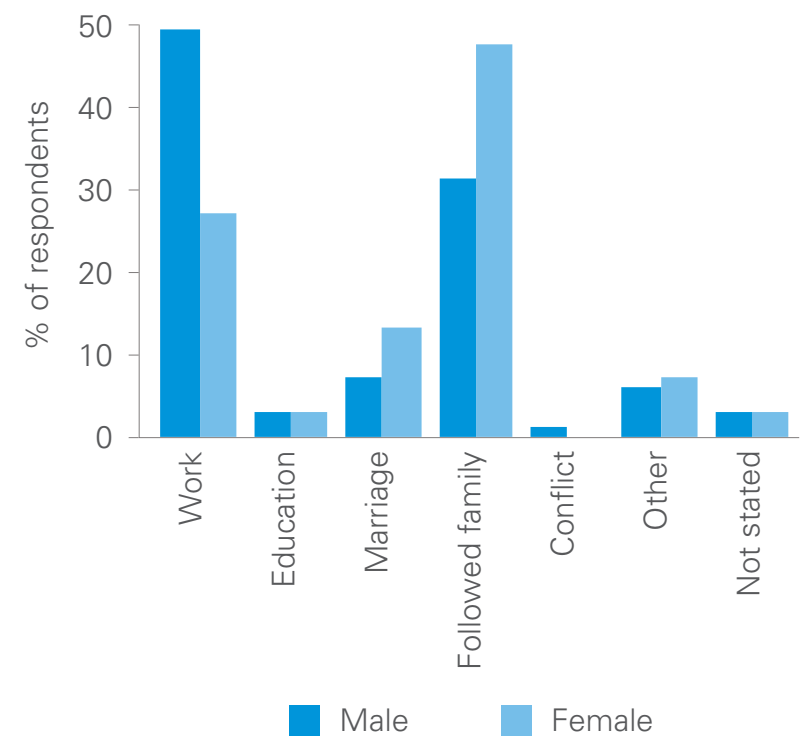

Source: Department of Population 2016. share of internal economic migrants may be higher (Department of Population 2016). These findings are corroborated by household and migrant surveys and qualitative studies. In the 2015 MPLCS, 56 percent of internal migrants reported their primary motivation was work or to accompany a family member moving to work (Figure 1.11). The Qualitative Social Economic Monitoring (OSEM) Survey in Ayeyarwady and Magway found that 74 percent and 71 percent of migrants from the two regions, respectively, moved either for a job or to look for work (Pattison et al. 2016b). Widespread underemployment and seasonal employment in agriculture drives individuals to seek more stable jobs, which may or may not pay more, in more dynamic rural areas or urban centers as part of a household's decision to stabilize household incomes and diversify income sources (Gupta 2016; Pattison et al. 2016b). Indebtedness was also a factor, with migration seen as the means to release families from debt (Deshingkar, Litchfield, and Ting 2019).

The difference in wages across states and regions of Myanmar is an important pull factor for internal migrants. Wage gaps for elementary occupations between Yangon and other states and regions are largest for Magway, Ayeyarwady, Bago, and Rakhine, with an average difference in median unskilled wages of MMK181 per hour. These differences persist even within the same sector. These are the states with some of the largest migration flows to Yangon.

Work or the search for work is the motivation for moving for almost all international migrants. In the 2015 MPLCS, a quarter of households with international migrants cited work, while another three-quarters cited the search for work as the reason for family members moving abroad (Figure 1.11). Surveys of migrants in Thailand and 
Malaysia find similar motivations for moving (Harkins, Lindgren, and Suravoranon 2017). The 2015 Myanmar Labor Force, Child Labor, and School-to-Work Transition Survey also found that 74 percent of international migrants moved in search of employment or business opportunities, while another 23 percent moved to take up jobs they had already secured (Min Zar Ni 2018). A 2018 International Organization for Migration (IOM) survey of migrant workers crossing the border between Myanmar and Thailand found that a quarter of the surveyed migrants were unemployed before leaving Myanmar, while the rest were either selfemployed or daily wage laborers. Search for employment was their main reason for moving to Thailand, with many of the surveyed migrants having undertaken this strategy before (IOM 2019). Similarly, the 2017 CHIME survey found that more than half of the migrants (internal and international) in the survey were not in paid work prior to migration, which highlights the lack of economic opportunity as a primary driver for migration (Deshingkar, Litchfield, and Ting 2019).

Qualitative studies find that household characteristics influence migration strategy; for instance, landless or near-landless households may be more likely to opt for longer internal migration for their livelihood or survival, with the entire or a major part of the family moving together. On the other hand, owners of small- or medium-sized farms may be more likely to opt for seasonal internal migration or international migration by one or two members (rather than the whole household) - this is also a livelihood strategy, but with the main aim of risk management and income diversification. ${ }^{11}$ Finally, better-off families may be more likely to choose internal migration from farm to better-paid nonfarm jobs in the formal sector, or international migration to safer, better-paying destinations through regular channels. For skilled workers, migration also offers opportunities for professional skills development. For this group, labor mobility is primarily a wealth accumulation strategy for upward economic and social mobility (Maharajan and Myint 2015; World Bank and CESD 2018).

Social networks, preferences, and aspirations often drive migration, particularly for young people, women, and semiskilled and skilled workers. Several studies report that young people seek nonfarm jobs with expectations of better working conditions (Pattison et al. 2016b; World Bank and CESD 2018; Deshingkar, Litchfield, and Ting 2019). ${ }^{12}$ Reports from their peers of better amenities and access to services in urban

\section{Figure 1.11}

Motivation for internal and international migration, 2015

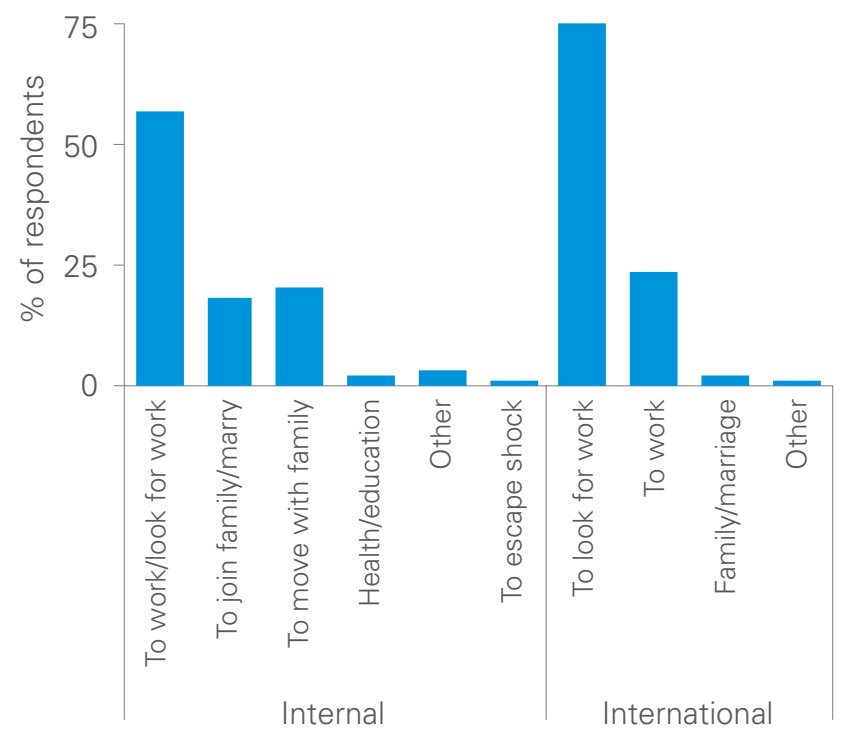

Source: Cunningham and Muñoz 2018a.

\footnotetext{
11 The 2017 CHIME survey found that the relationship between land ownership and patterns of migration varied across states and regions, reflecting differences in migration drivers as well as in the financial resources to migrate (Deshingkar, Litchfield, and Ting 2019).

12 Factory workers surveyed in one Yangon township referred to their jobs as than (clean) and yin kyay (more civilized), relative to work in muddy fields in the rain or sun (Boutry et al. 2016).
} 


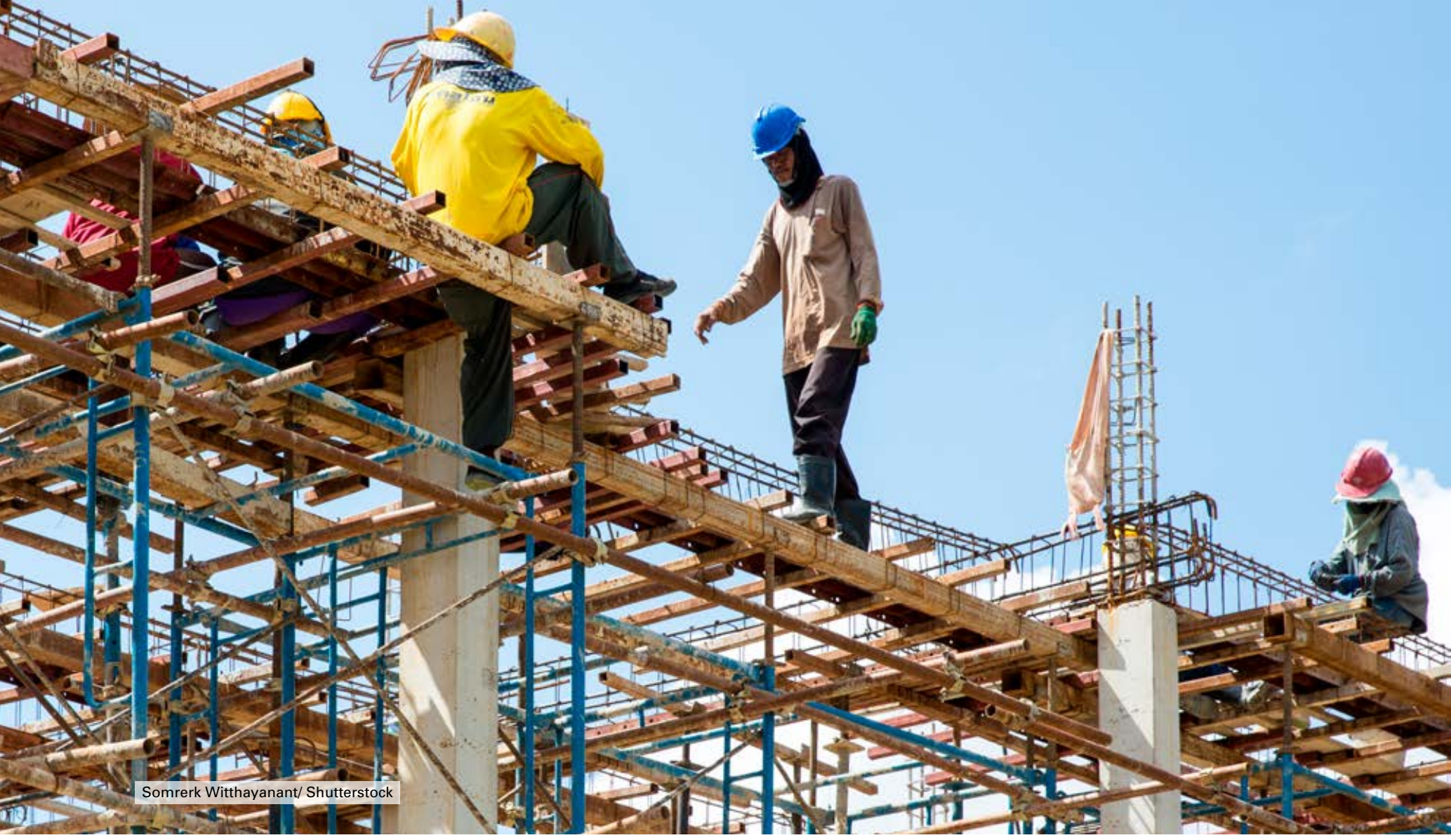

areas also fuel this desire for better living and working conditions and for an urban lifestyle. Anecdotal evidence suggests that a motivation for female outmigration from Shan is the prevalence of drug addiction among men in the state. Social exclusion is also a driver of labor mobility in some parts of Myanmar (University of Sussex and IOM 2017).

For those living in areas with a long history of migration, peer networks reinforce migration as a viable strategy for upward social and economic mobility (Gupta 2016; Pattison et al. 2016b; World Bank and CESD 2018). For instance, local residents of the Southeast have developed social networks that allow them to move further afield to Bangkok and Southern Thailand in search of higher wages, while recent arrivals to the Southeast lack such networks and seek out employment along the border (ILO 2015b; Maharajan and Myint 2015; Saw Yu May 2015; Harkins, Lindgren, and Suravoranon 2017; Min Zar Ni 2018; World Bank and CESD 2018).
In some areas, migration is a key survival strategy when adverse shocks disrupt primary livelihoods and services are not available to support them; for instance, natural disasters such as the Nargis cyclone in 2008 and floods in 2015 increased household vulnerability in the Delta and the Dry Zone. As a result, households with subsistence constraints migrated as a survival and coping strategy. This shock-response migration predominantly occurred within Myanmar, and was often localized within the same state and region because these migrants were typically from poor households, had suffered an economic loss, and lacked the resources and social networks for a well-planned migration to locations that were farther away (Pattison et al. 2016b; World Bank and CESD 2018). The lack of social services and public investment in these areas can be an additional push factor for migration, particularly when households are faced with negative shocks. In border states, migration across the border has been a common response to conflict and political factors. 


\section{Positive impacts of migration}

Labor mobility offers opportunities that can positively impact migrants, their families, and their communities. By taking advantage of greater employment opportunities and higher wages in the destination location, migrant workers can earn higher incomes and smooth consumption. When these higher incomes are remitted back to migrant-sending families, they can have a positive impact on household consumption levels and consumption patterns, reduce debt, and allow for investment in household assets, human development, and productive inputs. Migration can induce knowledge transfer and skills development of both job-related and soft skills and promote entrepreneurship, including among return migrants who have accumulated capital and skills during employment away from home. At the macro level, labor mobility can facilitate structural transformation through its impact on local labor markets in migrant-sending communities. Finally, labor mobility of both men and women can influence gender norms within households, particularly with respect to decision making and financial management, and it can improve women's bargaining power within households. Figure 1.12 summarizes these channels of impact.

\section{Income and consumption}

Analysis of data from the 2017 MLCS shows that migrants are 39 percent less likely to be poor compared to nonmigrants (World Bank 2019b). Migrants are also almost twice as likely to be in the wealthiest quintile. Most of this can be explained by the different sectors of employment and differences in education: Migrants tend to work in nonagricultural sectors, and they tend to have higher levels of education.

Evidence from migrant surveys and qualitative studies suggests that Myanmar

\section{Figure 1.12}

\section{Channels of positive impacts of labor mobility}

\section{Income and consumption}

- Household consumption levels and patterns including investments in human development

- Productive investments in agriculture and small businesses

- Increased stock of household wealth and assets; improvements in living conditions

\section{Skills, labor markets, and entrepreneurship}

- Acquisition of job-related skills and other "soft" skills (language, leadership, etc.)

- Structural transformation of local labor markets in migrant-sending communities

- Entrepreneurship among returnees (both migration-induced knowledge transfer and savings)

\section{Female empowerment}

- Shifts in gender norms, particularly decision-making and intra-household bargaining power 
Figure 1.13

\section{Share of migrant and nonmigrants by wealth quintile}

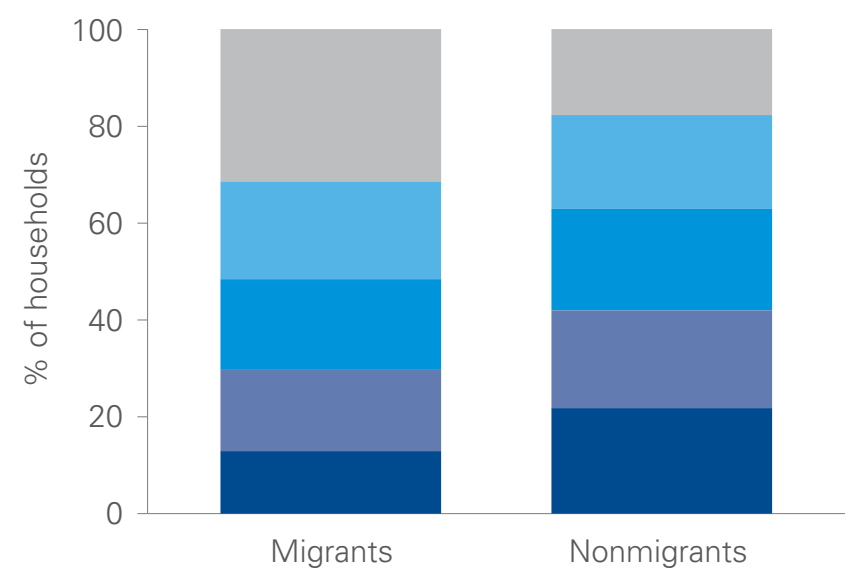

Q1 (lowest) Q2 Q3 $\quad$ Q4 Q5 (highest)

Source: World Bank 2019b

migrant workers earn more after moving abroad. In 2015, the average monthly wage in Myanmar was approximately US\$60 per month for paid (non-family) workers in microenterprises (Cunningham and Muñoz 2018a). ${ }^{13}$ Regular Myanmar migrant workers in Thailand could expect to earn about US\$225 per month in 2012 , and irregular migrants could expect to earn about US\$85-US\$140 per month (Chantavanich and Vungsiriphisal 2012). The longer workers remain abroad, the more they are paid. A 2009 survey found that migrants' median family income before moving to Thailand, after they first arrived, and at the time of the survey was about US\$45, US\$121, and US\$226, respectively (Jampaklay and Kittysuksathit 2009). A more recent study suggests that Myanmar migrants in Malaysia and Thailand, both regular and irregular, earned about US\$176 per month in 2016 (Harkins, Lindgren, and Suravoranon 2017).
Most Myanmar migrants send remittances to their families. The majority of international and internal migrant workers (estimated at about two-thirds to threequarters of surveyed migrants) report sending back remittances (Chantavanich and Vungsiriphisal 2012; IOM and ARCM 2015; Griffiths 2016; Pattison et al. 2016a; Harkins, Lindgren, and Suravoranon 2017; Deshingkar, Litchfield, and Ting 2019; IOM 2019). Those that do not send remittances tend to have their families with them. ${ }^{14}$ Remittances were the largest expense for some of these workers (Chantavanich and Vungsiriphisal 2012). The amount and frequency of remittances sent are associated with job security, wages, living costs, the intended purpose of the transfer, and the migrant-sending family's needs (Deshingkar, Litchfield, and Ting 2019). There is also some evidence of in-kind remittances (for example, clothing, food, and household and electrical appliances), but these are less commonly sent than cash remittances (Jampaklay and Kittysuksathit 2009; Deshingkar, Litchfield, and Ting 2019).

There are some patterns among remittancesending groups. Female migrants tend to send remittances somewhat more frequently. Although the average size remitted is lower, which reflects the lower wages female migrants receive, remittances tend to account for a greater proportion of their income compared to male migrants (Turnell, Vicary, and Bradford 2008; Jampaklay and Kittysuksathit 2009; IOM and ARCM 2015; Harkins, Lindgren, and Suravoranon 2017; Harkins 2019)..$^{15}$ Migrants who were economically active prior to migration were more likely to remit money home than those who were not

\footnotetext{
13 The average daily wage for all workers was about US $\$ 2.80$ for highly seasonal employment.

14 There is also some evidence of financial flows from migrant-sending households to migrants (Deshingkar, Litchfield, and Ting 2019).

The 2017 CHIME survey found that the average remittances from international migrant women and men were similar, while that of internal migrant women were about half that of men but were often supplemented by in-kind remittances (Deshingkar, Litchfield, and Ting 2019).
} 
economically active (42 percent relative to 30 percent) (Deshingkar, Litchfield, and Ting 2019). A 2018 IOM survey of migrants at the Myanmar-Thailand border found that migrants with documentation were more likely to remit than those with an irregular migration status (IOM 2019).

The volume of recorded international remittances to Myanmar in 2015 was about US\$3 billion, accounting for 4.6 percent of GDP. This was the fourth highest in ASEAN. These inflows have increased significantly in recent years; in 2013, international remittances amounted to US\$1.6 billion (Figure 1.14). There is no data on the volume of internal remittances.

The volume of international remittances is even higher if informal remittances are included. In 2015, the Ministry of Labor, Immigration, and Population (MOLIP) estimated that total remittances, including those sent through informal channels, was approximately US\$8 billion, or 13 percent of GDP (Akee and Kapur 2017). This figure is consistent with small-scale, mixedmethods studies of Myanmar migrant workers in Malaysia and Thailand (Akee and Kapur 2017; Ma 2017).
Figure 1.14

Inflow of remittances to Myanmar

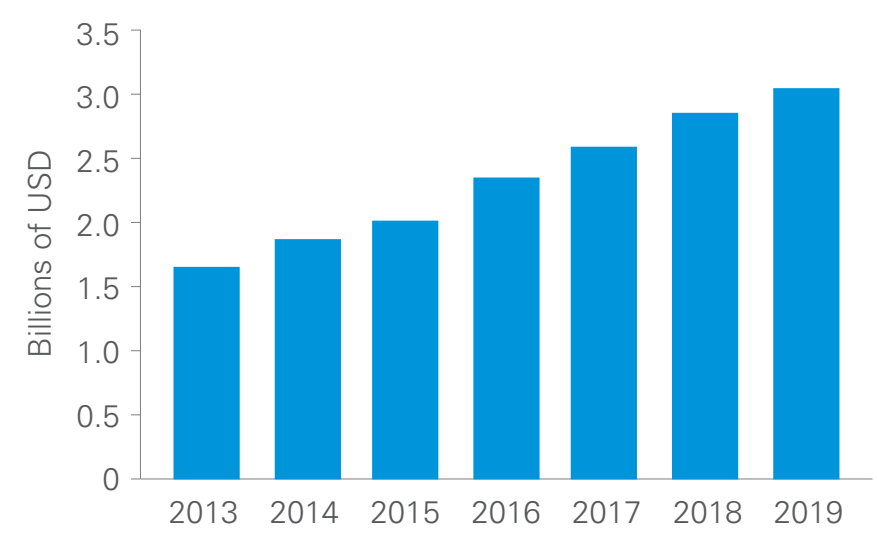

Source: World Bank 2019a.

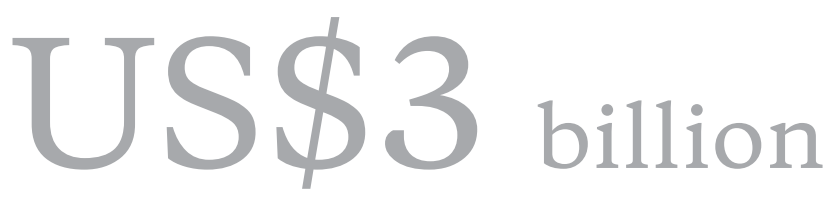

The volume of recorded international remittances to Myanmar in 2015, accounting for 4.6 percent of GDP

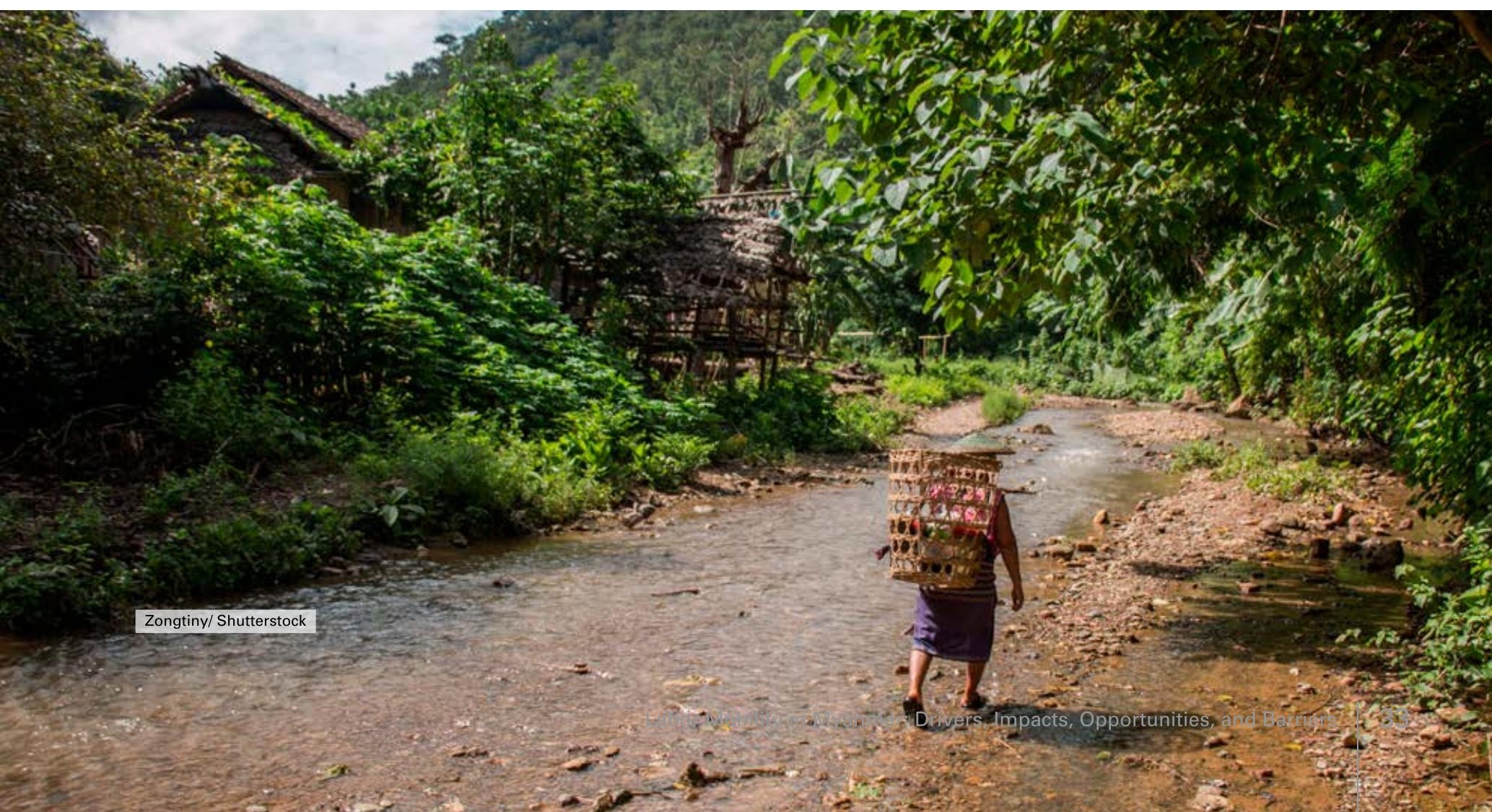


Figure 1.15

Remittance channels used by migrant workers in Thailand and Malaysia

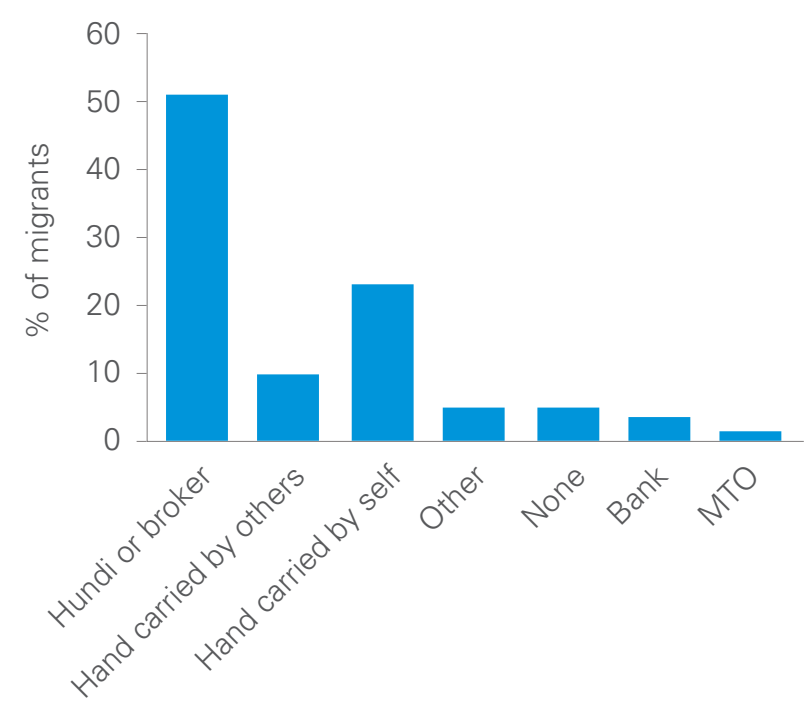

Source: Harkins, Lindgren, and Suravoranon 2017.

Figure 1.16

Formal and informal remittances by country of origin of remittances

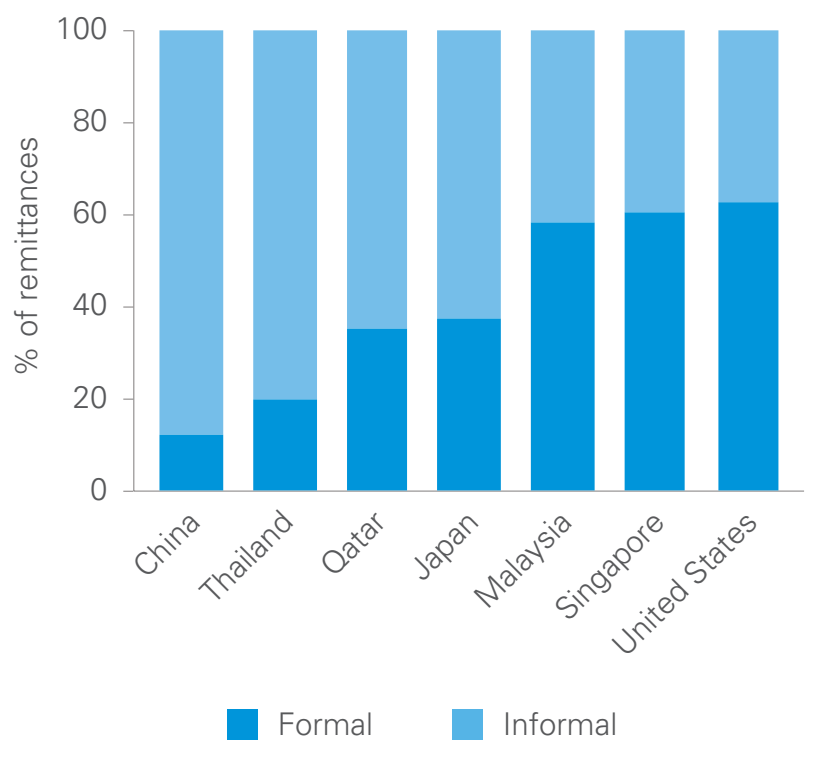

Source: UNCDF 2017.

The majority of international migrants rely on informal channels, mainly the hundi network, for remittances. Migrant surveys in Thailand estimate that nearly all migrants use the hundi system, friends or family, or carry money home (Turnell, Vicary, and Bradford 2008; Jampaklay and Kittysuksathit 2009; Akee and Kapur 2017; Harkins, Lindgren, and Suravoranon 2017) (Figure 1.15). A small survey of Myanmar migrants in Singapore also found that 90 percent of migrants used the hundi system, and only a small proportion used banks (Ma 2017). This preference for informal remittance channels is driven by considerations of trust, accessibility for the receiving families, cost, and convenience. Additionally, many migrant workers are unaware of the formal alternatives. Semiskilled and skilled workers are more likely to use formal channels than unskilled workers (Box 1.3).

In 2015, approximately 68 percent of the households in Myanmar that received remittances received them through informal channels, relative to only 32 percent through formal channels. In contrast, the share of households receiving remittances from formal channels in Cambodia and Lao PDR was 79 percent and 65 percent, respectively (UNCDF 2017). The share of Myanmarhouseholds receiving remittances from Thailand and China through informal channels was 80 percent and 88 percent, respectively, compared to those receiving remittances from Malaysia and Singapore (41 and 39 percent, respectively) (Figure 1.16) (UNCDF 2017).

Recent studies find that although informal channels continue to dominate the remittance-sending market, banks are gaining traction. In 2012, about 20 percent of migrant workers in Thailand reported using banks. A large share of the surveyed migrants were employed in food processing and other industries in which employers were paying wages into bank accounts (Chantavanich and Vungsiriphisal 2012; Kubo 2017). A 2017 survey of migrant- 


\section{Box 1.3 Factors behind the preference for informal remittance channels}

Government policy affecting remittances has shifted in recent years. Until late 2011, the government made it mandatory for regular migrant workers to remit between 30 and 50 percent of their wages through two state-owned banks, the Myanmar Foreign Trade Bank and the Myanmar Investment and Commercial Bank; both banks charged a 10 percent service fee per transaction. In response, the hundi network developed at the community level in Myanmar and in destination countries. In late 2011, private banks and money transfer companies were allowed to offer remittance services, and in 2012 the 10 percent fee was abolished. However, the spread of financial infrastructure within Myanmar has been slow, and the hundi system remains cheaper, quicker, and more convenient.

Accessibility of payment points for receiving families: In 2012, Myanmar had only 2 commercial bank branches per 100,000 adults, compared to 12 in Thailand. While financial infrastructure has improved since Myanmar's financial sector reforms in 2012, access to formal banking services is still low, especially for rural households. Myanmar migrants in Thailand were more likely to send remittances through banks if there were bank branches near their families in Myanmar.

Cost: It is difficult to estimate transfer costs, because fees differ across channels (for example, sometimes the remittance sender pays the fee, other times the remittance receiver pays the fee), although there are some patterns. For large transfers, banks probably make economic sense; for small amounts, money transfer firms such as Western Union charge less. In all cases, however, hundi is likely the cheapest mode of transfer.

Convenience: Informal channels are more convenient. They do not require documentation, such as a passport or work permits, or forms filled out in the language of the destination country. Most studies report that the hundi system collects directly from migrants (for example, in factories in some Thai provinces) and delivers directly to the receiving households.

Awareness: A study of migrant workers in Thailand indicated that most of them were unaware of the remittance-sending alternatives; this was particularly true for women. Earlier studies suggest that migrants often used the same agent that helped them find work. Both migrants and migrant-sending households lack financial literacy, so they are less comfortable using banks. Some migrants also cited poor customer service in banks as a deterrent.

Trust: Some studies of migrants in the early 2000s suggest that they lack of trust in formal institutions, possibly because of the previous government policy that controlled remittance flows. There are also cases of hundi agents giving cash advances to long-standing customers in case of an emergency.

Sources: Turnell, Vicary, and Bradford (2008); Jampaklay and Kittysuksathit (2009); Jirattikorn (2015); Kubo (2017); Akee and Kapur (2017); Ma (2017); UNCDF (2017); Min Zar Ni (2018). 
sending households in Myanmar found that 82 percent of international migrants in the sample had remitted funds using banks and other financial institutions, and only 8 percent had used the hundi network (as reported by migrant-sending households); however, in-depth interviews revealed that the hundi network was still widely used (Deshingkar, Litchfield, and Ting 2019). It is possible that migrants use financial institutions to deposit funds into the bank account of the agent who then remits using informal channels (Kubo 2017).

Remittances are an important source of income for recipient households. In 2013, 11 percent of Myanmar's population received domestic remittances, while 7 percent received international remittances (UNCDF 2017). Women were the main recipients of remittances: 59 percent and 54 percent of the people receiving international and internal remittances, respectively, were women. In the 2017 MLCS, about 7.5 percent of households reported receiving international remittances from former household members, with high shares in Kayin (38 percent) and Mon (32 percent), as well as in other states and regions such as Shan and Bago (World Bank 2019b). ${ }^{16}$ Most of these remittances came from Thailand. In Mon state, one study found that remittances were the second largest source of income (after agriculture) (Filipski et al. 2019). Most studies find that remittances are largely used for food and other daily needs; studies in the early and late 2000s found that almost the entire amount was used to meet day-today expenses on food, clothing, and other necessities, with a small proportion used for health care costs, education, and other purposes (Jampaklay and Kittysuksathit 2009). This is consistent with the claim that it is underemployment, low wages, and negative shocks that are the key drivers of labor mobility in Myanmar.

More recent studies find that day-to-day expenses now account for about threequarters of the remittance amount, rather than almost the entire amount, possibly indicating a shift from consumption to savings and investment, including in children's education (Chantavanich and Vungsiriphisal 2012). Evidence on the secondary uses of remittances suggests that once subsistence needs are met, migrant-sending households invest in health care, education, home improvements, and agricultural inputs (Pattison et al. 2016b). A 2013 study finds that remittance recipients are more likely to save relative to the general population (47 percent versus 38 percent) (UNCDF 2017). A 2018 study of migrant-sending households in Mon state found an increase in food consumption after a family member migrates, but also that savings constituted the largest use of remittances (Khin Soe Kyi 2018). The 2017 CHIME survey found that although food was still the most common item on which remittances were spent, about 20 percent of remittance-receiving households reported investing in production assets (such as land, seeds, fertilizers, and other production inputs, as well as farm machinery, boats, and fishing equipment) (Deshingkar, Litchfield, and Ting 2019). Some studies also report households' use of remittances to make religious donations or community contributions, as a way to raise their social status (World Bank and CESD 2018; Deshingkar, Litchfield, and Ting 2019). In general, remittances from within Myanmar are too small for major savings or investment. Any investment from these internal remittances tends to be in petty trading or livestock, compared to the investment of international remittances

16 This only includes remittances from former household members or individuals who had been away from the household for more than six months in the 12 months preceding the survey. 
in land or small enterprises (Maharajan and Myint 2015).

Although limited, there is evidence of a positive correlation between labor mobility and household welfare in Myanmar. A study of Myanmar migrants in Thailand and Malaysia found a small decrease in the proportion of those living below the international poverty line (Harkins, Lindgren, and Suravoranon 2017). About 85 percent of migrant workers reported being poor before moving to these destinations, whereas 72 percent remained poor on their return to Myanmar. Migrants reported an increase in asset ownership, particularly of assets like motorcycles, white goods like refrigerators and televisions, mobile phones, and gold after migration. Average monthly incomes doubled from US\$28 prior to migration to US\$59 on returning to Myanmar.

There is also evidence that migration and remittances have a positive impact on subjective measures of well-being. Several studies find that migrant-sending households, especially those receiving remittances as a result of successful migration, experience improvements in their social status (Pattison et al. 2016b; Deshingkar, Litchfield, and Ting 2019). For instance, a 2018 IOM survey of return migrants at the Myanmar-Thailand border found that the majority (59 percent) reported that their general financial situation had improved, while 20 percent reported no change. Only 17 percent of surveyed return migrants reported deterioration, mainly due to debts or low wages and poor quality jobs in Thailand (IOM 2019). The 2017 CHIME survey also found a link between migrant-sending households who received remittances and their selfperception of poverty. A larger share of households receiving remittances reported improvements in their subjective poverty ranking, relative to those not receiving

\section{Although limited, there is evidence of a positive correlation between labor mobility and household welfare in Myanmar}

remittances; a smaller share reported a decline in their ranking (Deshingkar, Litchfield, and Ting 2019). This is consistent with international evidence on the links between migration and poverty (Box 1.4).

\section{Skills, labor markets, and entrepreneurship}

Myanmar migrants acquire skills during migration. A survey of Myanmar migrants in Malaysia and Thailand found a shift from low-skilled work before migration to semiskilled or skilled work afterward (Harkins, Lindgren, and Suravoranon 2017). Only 9 percent of migrants were engaged in semiskilled or skilled work before migration. This increased to 17 percent upon return. The share of workers engaged in low-skilled work dropped from 84 percent before migration to 71 percent after migration. However, the share of those unemployed also increased from 8 to 12 percent, suggesting that not all return migrants have the opportunity to apply their new skills. Return migrants in the Southeast reported acquiring language and business skills, as well as skills in rubber tapping, cooking, and factory work while working in Malaysia, Singapore, and Thailand, (Min Zar Ni 2018; World Bank and CESD 2018). 


\section{Box 1.4 International evidence on the links between migration and poverty reduction}

International evidence shows a strong link between migration and poverty reduction. An analysis of 71 developing countries found that both international migration and per capita remittances lead to reductions in the number of people living on less than a dollar a day (Adams and Page 2005). This positive relationship was confirmed by a regional study of 24 Asia Pacific countries (Imai et al 2014). Another study of 10 Asian countries found that remittances are powerful in reducing poverty depth; a 1 percent increase in remittances is associated with narrowing the average shortfall in income or consumption from the $\$ 1.90$-a-day poverty line by 22.6 percent (Yoshino, Taghizadeh-Hesary, Otsuka 2017). At the country level, remittances impact the well-being of recipient households. For instance, in Indonesia, the probability of being poor fell by 29 percent for households receiving remittances in both 2000 and 2007 (Cuecuecha and Adams, 2016). In the Philippines, Nepal, and Vietnam, receipt of remittances smoothed household income fluctuations by counteracting the drops in income that resulted from adverse shocks of typhoons and an earthquake (Yang and Choi, 2007, De et al. 2019, World Bank 2016, Groger and Zylberberg 2016).

International evidence suggests that as migrant households become less poor, remittances are increasingly used for savings and investments. Globally, remittances are used to make investments in education, agriculture, and business start-ups. For instance, in Indonesia, households that received remittances in 2007 spent 332 percent more at the margin on education than what they would have spent without remittances. These remittances also contributed to reducing child labor (Cuecuecha and Adams 2016). Remittance-induced investments in education result in human capital development and a more skilled labor force in the future. Studies in a number of African countries (such as Morocco, Nigeria, and Tunisia) found that remittances enabled recipient households to make investments in commercial agriculture through the purchase of equipment, fertilizers, and other inputs (de Haas 2001, Konseiga 2004, Iheke 2014). ${ }^{17}$ In Mexico, Pakistan, and the Philippines, remittances are an important source of capital for small and micro businesses, particularly among women (Yang 2004, Olmedo and López Córdova 2006, Ilahi 1999). Remittances also contribute to building family wealth and assets (for example, housing in Vietnam and the Philippines) (Eversole and Johnson 2014).

Source: Yi 2018

17 In Nepal, in contrast, high outmigration has resulted in a shortage of family labor and the neglect of subsistence farming (Maharjan, Bauer, and Knerr 2012). 
There is some evidence of a shift from farm to nonfarm work among migrants. The 2015 MPLCS shows that professionals and semi-skilled workers tended to stay in the same occupational group after migration (Cunningham and Muñoz 2018a). However, a third of farm owners shifted to semi-skilled work, and another third shifted to unskilled nonfarm work. There was also some movement for unskilled workers from farm to nonfarm work, to farming as farm owners, and to semi-skilled work. The 2017 CHIME survey found that migrants moved from work in agriculture, forestry, and fisheries before migration, to other nonfarm sectors, especially manufacturing, construction, and services when they migrated (Deshingkar, Litchfield, and Ting 2019). And the majority of migrants in irregular employment before migration obtained regular employment when they migrated (Figure 1.17).

Labor mobility may have longer-term costs regarding educational attainment and skills development. Studies of internal migrants and of international migrants in Thailand indicate that the majority migrated while they were young, often as adolescent youth. Factors inducing youth to migrate from the Southeast to Thailand, even at the expense of dropping out of secondary or high school, include peer pressure, the attraction of higher wages, and a more urban lifestyle (Soe Lin Aung 2014; Min Zar Ni 2018; World Bank and CESD 2018). This runs counter to the aspirations of parentsmigrants and returnees- who seek more education for their children (World Bank and CESD 2018). Migration disincentivizing educational attainment is an effect that has been observed in other countries as well (de Brauw and Giles 2018).

Labor mobility stimulates entrepreneurship in Myanmar, especially in communities where return migrants are successfully reintegrated. In Myanmar, return migrants are more likely to be self-employed and to be engaged in nonagriculture work

\section{Figure 1.17}

Employment type at migration destination for migrants in irregular work before migration

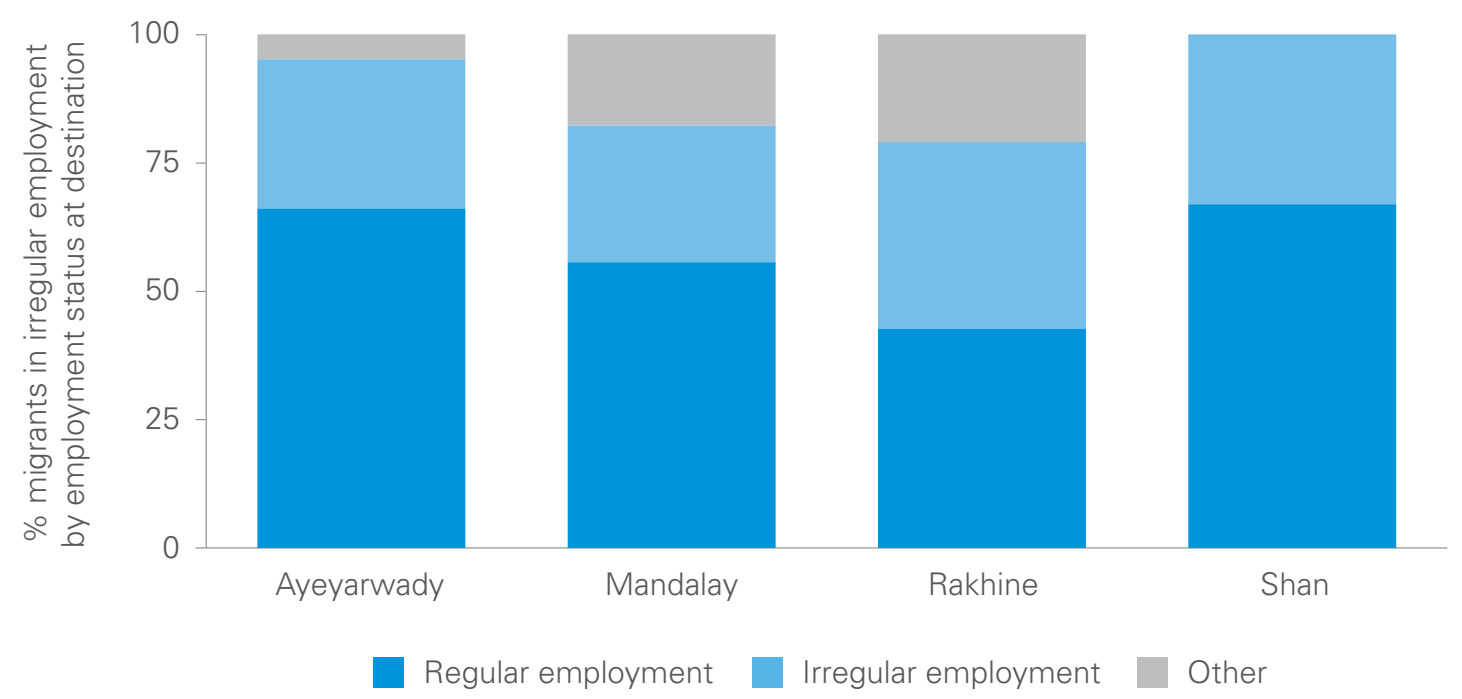


(Harkins, Lindgren, and Suravoranon 2017). The migration experience can help returnees acquire the capital and skills required to set up small businesses. For instance, six of eight hotel industry representatives interviewed in Tanintharyi were return migrants from Malaysia and Thailand (World Bank and CESD 2018). Entrepreneurship, in turn, creates wealth and generates jobs in local communities. Improved access to microfinance since the 2012 financial and banking reforms, has facilitated this process (Turnell 2014; Ma 2017).

In the long run, labor mobility may encourage structural transformation in Myanmar. In Myanmar, internal and international migration has resulted in labor shortages in rural migrant-sending communities. Most Myanmar communities surveyed in studies of internal migration report labor shortages during the peak agricultural season as a result of internal mobility (ILO 2015a; Maharajan and Myint 2015; Pattison et al. 2016b; Deshingkar, Litchfield, and Ting 2019). A state-level survey in Mon state found that the labor shortage that resulted from outmigration increased wages for unskilled agricultural workers (Filipski et al. 2019). This effect persisted, despite the inflow of internal migrants-usually for temporary work during the peak agricultural season. Although this labor shortage can impose a short-term cost on communities dealing with the neglect of farms and rising wages, it can have long-term benefits by facilitating structural transformation. For instance, these studies found that some communities have pursued mechanization in response to the labor shortages induced by outmigration (Filipski, Belton, and Asselt 2018; Filipski et al. 2019). ${ }^{18}$

\section{Female empowerment}

In 2014, women comprised 52 percent of internal migrants and 38 percent of international migrants (Department of Population 2016). Their share of international migrants may be higher, given that women are over-represented among the irregular migrants most likely to be left out of official estimates. Women are also the main recipients of remittances. In 2013, 59 percent and 54 percent of the people receiving international and internal remittances, respectively, were women (UNCDF 2017).

Migration can increase women's independence and autonomy by enhancing their bargaining power in their households. For instance, three-quarters of female returnees from Thailand and Malaysia felt they had greater control over household decisions (Figure 1.18). For some household decisions, many more female migrants reported an increase in their decision-making power relative to men, including in decisions related to finances, purchases, and spending on education and health care. Many women also reported feeling more self-confident and independent, having more control of their lives, and being treated with respect as a result of migrating (Harkins, Lindgren, and Suravoranon 2017).

Women can also become empowered when men migrate, especially when women take over the family decision making and take a more active role in the community. The limited evidence for Myanmar suggests that this is more common in the case of international migrants and in the case of internal migrants from communities with low connectivity. In both cases, decision

18 Similarly, internal migration in China and India has facilitated the reallocation of workers from low to higher productivity settings. As a result, migration contributes to overall productivity and efficiency gains and to poverty reduction in rural areas, both through rural-urban migration (as in China) as well as through rural-rural migration (as in both China and India) (Yi 2018). 


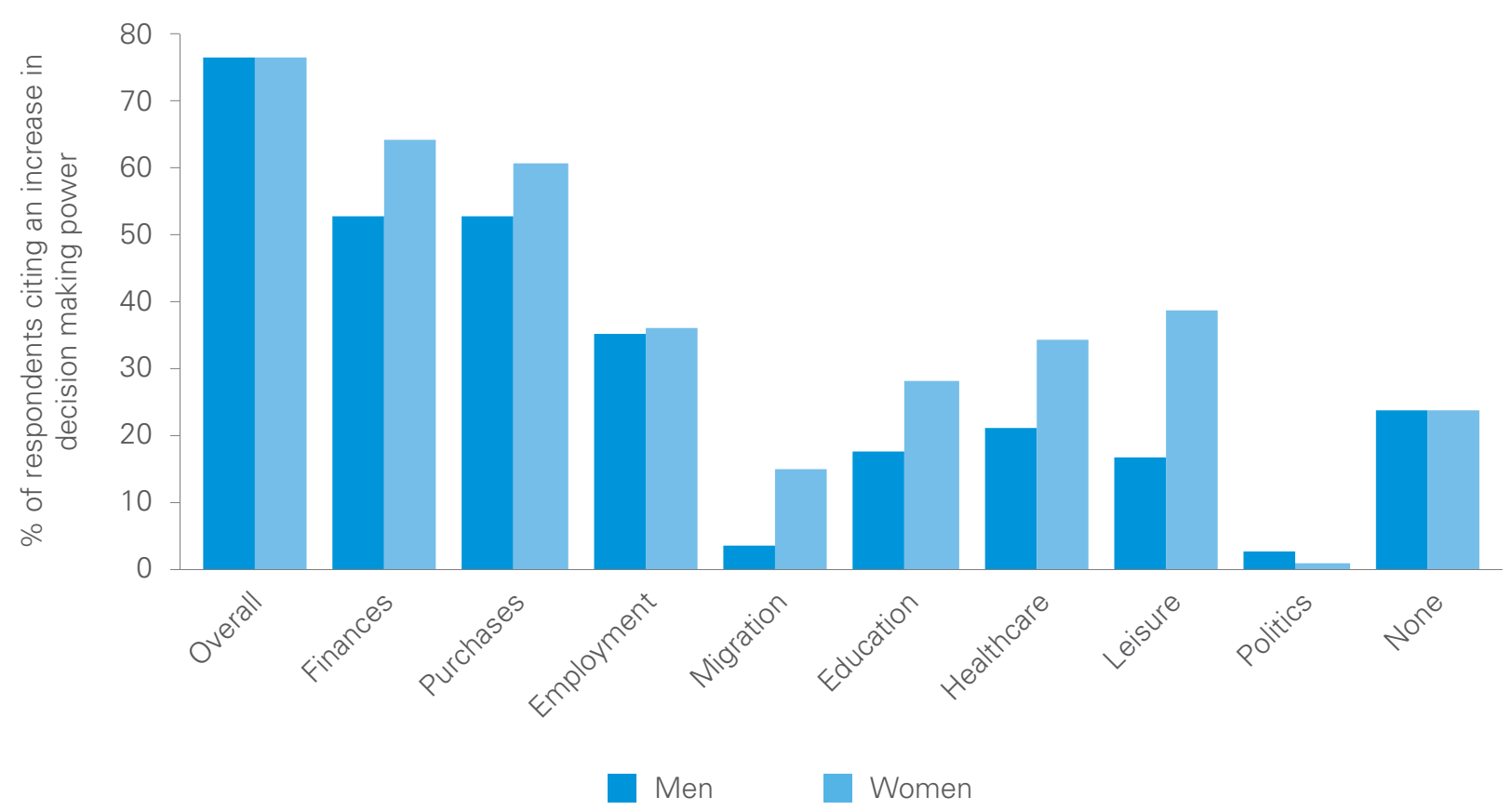

Source: Harkins, Lindgren, and Suravoranon 2017.

making transfers to the female household members staying behind. In areas with high connectivity, the male migrant retains his decision-making power even from a distance. In the case of internal migration, families remain closely connected and migrants are generally able to return to support their families in times of need (Maharajan and Myint 2015; Pattison et al. 2016b). Although women are starting to take more of a lead role in farming, there does not yet appear to be any impact in terms of an increased role for women in community social and economic activities, at least not as a result of internal migration (Maharajan and Myint 2015). International evidence provides support for migration's impact on gender norms (Box 1.5).

\section{Box 1.5 International evidence on migration and gender norms}

The role of migration in changing gender norms is apparent in other countries. For instance, in Bangladesh, women migrants in the garment industry find that their higher incomes reflect their greater decision-making role in their households, including in the allocation of income between expenses and savings (Kakuli and Risberg 2012; Kabeer 1999). These workers also demand that labor unions respect their rights and recognize their specific needs. In the Philippines, gender norms are shifting due to mothers' migration as fathers take on child care responsibilities (Lam and Yeoh 2018). Returnees can also foster this change; for example, Greek migrants returning from Germany are moving away from the traditional roles of husbands and wives, adopting instead the new roles they were exposed to in Germany (Sakka, Dikaiou, and Kiosseoglou 1999). 


\section{Unintended consequences of migration}

Labor mobility can have unintended consequences for migrants, their families, and their communities. Families face difficulties when a household member migrates, and care responsibilities shift, and that disruption happens again when a migrant returns home. Other challenges relate to interaction among migrants, local residents, and local authorities. Returning migrants can face difficulties re-enrolling children in school and face issues related to mental and physical health. And migration attempts that do not succeed can have significant financial consequences, because of the loss of money invested in the attempt. Figure 1.19 summarizes these channels.

\section{Family disruption}

The migration of working-age adults can impact intergenerational support systems for older persons and young children who remain behind. For instance, while children of migrant households may be more likely to enroll in school (as remittances can ease financial constraints), attendance may be lower, especially when parents are away, possibly due to the reduced disciplinary role of the remaining adults. ${ }^{19}$ A 2012 survey of older persons in Myanmar found high rates of coresidence, with most old people living with their children. However, between 2 percent and 10 percent of older people

Figure 1.19

Perceived change in decision-making power after migration

\section{Family disruption}

- Disruption of intergenerational support systems

- Adverse impacts on nutrition and early childhood development

\section{Integration challenges}

- Social tensions between migrants and local residents

- Challenges associated with local authorities

- Lack of social protection, labor rights, and access to services

\section{Reintegration challenges}

- Erosion of family roles

- Challenges of continuing schooling for children

- Negative effects on physical and mental health

\section{Failed migration}

- Financial costs

Source: Authors, based on Yi (2018).

19 Studies in China have found both negative and positive impacts on the education and health of left-behind children (Chang et al. 2018; Bai et al. 2018; Gao et al. 2010). In the Philippines and Mexico, children of migrant mothers are more likely to have weak academic performance and behavioral and emotional problems (Lahaie et al 2009, Asis 2006, Battistella and Conaco 1998). Health effects are more mixed: children of migrant fathers in Indonesia and Thailand are more likely to have poor psychological well-being, but this is not the case in the Philippines and Vietnam (Graham and Jordan 2015). The evidence suggests that the effects of parental migration on children's outcomes are mixed, depending on various factors such as the gender of the migrant parent, the role of remittances, and the outcomes being examined. There is also some evidence that temporary circular migration increases the risk of family breakdown, including the social isolation of elderly parents. 
lived in "skip generation" householdsthat is, households where grandparents take care of their dependent grandchildren, because the children's parents, more often than not, had migrated (Knodel 2013). A 2014 survey of Myanmar migrants in Thailand found that a large share of migrant workers had children being taken care of by grandparents. About half of this group had children living in skip generation households, with their grandparents taking care of them. The majority of migrants remitted money to those grandparents, and believed this money was used for their children's care, compensation for child care, and household expenses. Most migrants maintained regular contact by telephone, and in some cases, through visits (Knodel et al. 2015).

While labor mobility and labor force participation can empower women, family separation can also adversely impact nutrition and early childhood development. Many women migrant workers, particularly those working in Thailand, are unable to care for their children and work at the same time, and so they send infants back to their families (World Bank and CESD 2018). A 2017 survey from the Dry Zone found that there were some negative impacts on children whose mother or both parents migrated beyond the township, particularly in terms of meal preparation. However, children with migrant fathers received greater support with personal care and meal preparation, compared to children with a migrant mother, both migrant parents, or with nonmigrant parents. Because those children remaining behind were still embedded in family networks and cared for by other household members, there were no significant differences in emotional support among these groups of children. In addition, some negative impacts of a parent's absence due to migration may be offset by the benefits from remittances (Teerawichitchainan and Knodel 2019). ${ }^{20}$

\section{Integration challenges}

Communities with high rates of inmigration can face social tensions between migrants and local residents. Migrants living in informal settlements (both urban and rural) undergo cycles of squatting, eviction, and movement to other local settlements. This frequent movement can lead to the breakdown of social interconnectedness and mistrust among neighbors (Kyed 2017; Than Pale 2018). In diverse communities, factors including mistrust, political competition, poverty, vulnerability, and inequality can increase the social tensions associated with xenophobia and discrimination, and they can pose a risk for conflict and violence (Freeman, O'Connor, and Zongollowicz 2018).

Attitudes of local authorities toward migrants vary across locations. While migrants are often blamed for increased crime by local residents, migrants themselves, especially women, perceive themselves to be at greater risk and unprotected by local authorities (Maharajan and Myint 2015; Kyed 2017; World Bank and CESD 2018). In Yangon, for example, one study found that the attitudes of ward leaders ranged from sympathetic and pragmatic to indifferent to migrants, while civil society organizations (CSOs) were largely sympathetic (Kyed 2017). In the Southeast, there is an increasing concern about the number of, and the dependency on, internal migrants. In the rural areas of Kayin and Tanintharyi, internal migrants were not encouraged to stay after the completion of work, and local authorities 
did not register internal migrants as local residents (World Bank and CESD 2018). In Mon, however, local authorities registered internal migrants as local residents and issued identity cards, which later became a source of rising social and political tension.

Myanmar migrants to Thailand also face challenges related to integration. Despite their importance to the economy, immigration policy in Thailand has often reflected concerns that Myanmar migrants would take away jobs from locals, increase crime, or otherwise become a permanent burden to the country. These concerns were the basis of policies aimed to control the Myanmar migrant population in the 1990s. It was only in the early 2000s that immigration policy in Thailand recognized the economic role played by Myanmar migrants in the Thai economy (Jirattikorn 2015). However, a 2012 survey found that most Thais underestimated the economic contribution of migrants in their communities, and they perceived migrants, especially irregular migrants, as a threat to their safety and as competition for jobs, land, and natural resources (Sunpuwan and Niyomsilpa 2012). A larger share of urban residents held negative views relative to those living in the border areas.

Internal migrants report challenges regarding access to protection and labor rights. An International Labor Organization (ILO) survey of internal migrants in 14 states and regions found evidence of exploitation and labor rights abuses, including forced labor, misleading employment contracts, restrictions on movement and changing jobs, withholding of documents, and violence (ILO 2015a). Twenty-six percent of the surveyed internal migrants were in situations of forced labor, while 14 percent were in situations of human trafficking. Most migrant workers worked long hours, seven days a week, usually without overtime and without leave..$^{21}$

Migrant workers may also lack adequate housing. Most internal migrants, especially women, live in employer-provided housing, usually dormitory-style sleeping arrangements. The ILO study of internal migrants in 14 states and regions found that 65 percent lived in such accommodations (ILO 2015a). The situation is mixed for international migrants. Most international migrants in Thailand did not receive accommodations from employers but reported that conditions were adequate (Harkins, Lindgren, and Suravoranon 2017). Another study of female migrants in ASEAN found that for international migrants, employer-provided housing, of variable quality, was more common (UN Women 2017). While employer-provided housing reduces the living costs for migrants, it allows employers to closely supervise and control workers at all times. The living conditions are also often overcrowded; internal migrant respondents in the ILO survey reported sharing sleeping quarters with six others, on average (ILO 2015a). Also, boundaries between men and women's sleeping quarters are not always maintained, leaving female migrants at risk of sexual harassment (UN Women 2017).

Migrants often need to make informal payments to obtain official documents (IDs, or household registration) that are required to obtain formal employment and to access credit, education, and other services. Those with some financial means and connections have better access to these services, and there is some evidence of stronger support networks among ethnic minorities (IOM and ARCM 2015; Kyed 2017). For international migrants, access to health services, especially those provided at migrant clinics, is reported to be easier

21 This may be an overestimate, however, as this survey selected migrants in sectors more exposed to the risk of exploitation. 
than access to education (IOM and ARCM 2015; Harkins, Lindgren, and Suravoranon 2017; World Bank and CESD 2018).

\section{Reintegration challenges}

International migrants (in Thailand) and returnees (in Southeast Myanmar) cite a range of reasons for return. These include personal reasons (like the desire to be reunited with family), specific timebound tasks (for example, house repair or construction, ill-health of a family member), factors that make it harder to work at the destination (like employer preferences for younger workers, hardship, and poor living conditions, particularly for undocumented migrants in some sectors like fishing), and economic reasons (like a perceived increase in opportunities in Myanmar coupled with having saved enough to purchase land or start a small business) (Chantavanich and Vungsiriphisal 2012; IOM and ARCM 2015; Mya Mya Thet and Pholphirul 2016; Min Zar Ni 2018; World Bank and CESD 2018). Recent surveys also cite the role of documentation (expiry of work permits or desire to apply for one) as a factor in return migration, especially in the case of cyclical migration (IOM 2019).

Although most migrants in Thailand express a desire to return to their homes in Myanmar, few have concrete plans to do so. A small 2014 survey found that nearly threequarters of surveyed migrants planned to return, but the majority of them wanted to wait and consider rather than returning in the next year or two. Older, more educated migrants and those in regular contact with their families in Myanmar were more likely to want to return. Long-duration migrants were less likely to return (Mya Mya Thet and Pholphirul 2016). A 2018 survey of return migrants at the Myanmar-Thailand border found that nearly two-thirds of the surveyed migrants expected to face challenges upon return, with mental health issues the greatest among them (IOM 2019). Other challenges included finding a job or accommodation, physical health, and repaying debts.

Return migrants and their families face reintegration challenges, particularly as a consequence of the family disruption during the migration period. For instance, some return migrants report feeling depressed at the emotional distance they perceive from their children who have grown up with their grandparents (Harkins, Lindgren, and Suravoranon 2017; World Bank and CESD 2018). The separation of children from parents, particularly for longduration migrants, can erode the parents' perceived role as household heads and providers of care. CSO representatives in the Southeast report rising instances of marital issues, including separation and divorce, as well as substance abuse when migrants return home (Min Zar Ni 2018; World Bank and CESD 2018). For internal migrants, migration spells that last beyond the agricultural lean season can potentially erode existing patron-client relations, making it harder for returnees to find farm work when they return (Pattison et al. 2016b; World Bank and CESD 2018).

For children who accompany their families when they migrate, schooling can be an issue. This is less true for internal migrants who typically enroll their children in government schools at the destination. The exception is migrants in the construction sector, where access to education for accompanying children is more difficult (Maharajan and Myint 2015). For international migrants, children tend to accompany parents to Thailand but many do not go to school. An estimated 200,000 school-age migrant children are out of school in Thailand (Harkins 2019). For those that do go to school, their ability to continue their education on their return to Myanmar 
depends on whether they studied in a Myanmar migrant learning center or in a Thai government school. The former can enroll in Myanmar government schools on their return but, until recently, the latter could not do so, as the two education systems were not aligned. In 2016, the Thailand and Myanmar governments initiated a new program of Myanmar language night classes for children in Thai schools. These enable students to take Myanmar school exams in grades 4 and 8 (recognized in 2016) and grade 10 (recognized in 2014) (World Bank and CESD 2018).

Migrants may experience physical and mental health issues resulting from some aspects of the migration process. For instance, many migrants may have experienced exploitation by employers; insecurity, violence, or abuse; or unsafe or unsanitary working conditions that increase the risk of injury or disease. These workplace stressors have an adverse impact on mental health, which can lead to depression and anxiety (Meyer et al. 2015). Return migrants do not have access to adequate health care to address these issues. In addition, many do not discuss their negative migration experiences, due to fear of social exclusion, especially if they return with stigmatized diseases such as HIV (MMN 2016).

Birth registration and identification is a challenge for children born abroad to international migrants. International migrant families need to make informal payments of approximately MMK10,000MMK 40,000 (approximately US\$6- US\$25) in the Southeast to get a Myanmar birth certificate. This is required to add the infant to the household register and to obtain an identity card in Myanmar (World Bank and CESD 2018).

\section{Failed migration}

Migration can impose a financial burden on the migrant-sending household if a migrant returns having earned less than expected. The financial burden of migration that results in the migrant returning earlier than expected is higher for international migrants relative to internal migrants, given the higher migration costs and the greater reliance on borrowing to finance migration (Maharajan and Myint 2015; Pattison et al. 2016b). A variety of factors increases the risk of failed migration. Migrants often face high and unexpected costs. Among international migrants to Malaysia and Thailand, nearly half of those taking loans do so from money lenders, usually at high interest rates. The average time taken to repay is 10 months. There is also evidence that migration is financed, particularly in some sectors such as domestic work, by employers or agencies who then deduct the migrant's wages at the destination. Sometimes migrants are unaware of the extent of these deductions and of their debt liabilities (ILO 2015a; Harkins, Lindgren, and Suravoranon 2017; UN Women 2017). Migrant workers are often exposed to occupational hazards, and workplace injuries can cause unanticipated expenses, lead to indebtedness, and even cut short the migration period. Returnees who have been arrested and forcibly deported suffer the psychological as well as economic consequences of failed migration. Failed migration can shape a community's perceptions of migration (Box 1.6). 


\section{Box 1.6 Community experiences of migration}

At the community level, the experience of the first few migrants can shape its perceptions of migration. This experience can shape opinions about migration in general and about a particular destination, and can encourage or discourage others from following suit. Studies in the Delta and the Dry Zone suggest that villages tend to test the waters by sending a few pioneer migrants to a particular destination identified on the basis of expected returns relative to the cost of migration. Proximity, social networks, and family resources also play a role.

The failure of these pioneers seems to deter future migration. For example, instances of human trafficking in some villages have deterred aspiring migrants from moving. In one village, the village head had migrated to Malaysia in the past but returned following a bad experience. He now discourages aspiring migrants from leaving the village and does not readily provide recommendation letters.

On the other hand, when pioneers succeed, they provide a path for others in the community to follow. For instance, in a village in Magway, the first person to leave the village moved to Yangon nearly 40 years ago. He remains the main source of information on jobs and is responsible for connecting most migrants from the village to his sector of work in Yangon. Though not a broker, most migrant-sending families that he helped reciprocated by providing in-kind support and care to his extended family in the village. Similarly, the first person to go to China four years ago followed a person from another village in the village tract. This was seen as a risky move, but his success led others to follow him.

Shan and the Southeast have witnessed substantial long-duration international migration, often for three or four decades. Several elderly return migrants surveyed in Kayin had migrated in their early twenties several decades ago. As a result, going abroad for work is now considered the norm, and most of the young generation is planning to do so. There are also cases of entire families migrating to Thailand in the last 10 years or so. 


\section{Migration's unrealized potential}

The opportunities offered by labor mobility may not be fully realized due to barriers at different stages of the migration process. High direct and indirect costs of labor mobility can deter labor migration. In response to these barriers, households and individuals may opt not to move, and thus do not have labor mobility as a viable strategy for poverty reduction, income diversification, upward mobility, or wealth accumulation. For those that choose to migrate, barriers can make labor mobility riskier. For instance, international migrants may opt for irregular channels for migration that are less costly but bring a greater risk of exploitation. These choices can reduce the gains from migration.

Barriers are often more pronounced for the vulnerable, making it difficult for poor households to take advantage of the opportunities offered by international migration. Without savings or assets to sell or use as collateral, these households cannot borrow from local moneylenders (ILO 2015b). As a result, even with help from their families, their resources are only sufficient to finance internal migration, for which both migration costs and returns are lower than for international migration. For instance, Ayeyarwady has one of the highest poverty rates in the country, and only 9 percent of migrants from the region moved to international destinations (Pattison et al. 2016b; CSO, UNDP, and World Bank 2019).

Financial barriers can limit potential gains from mobility. For migrants from poor households, the inability to cope with failed migration leads many to attempt to secure jobs before they move, typically using social networks. Although this mitigates risk, it ties them to low-wage jobs and precludes them from investing in potential opportunities that provide more long-term benefits. Better-off households use labor mobility as a wealth accumulation strategy and tend to gain more from migration as a result (ILO 2015a; Pattison et al. 2016b).

The level of education and gender affect the gains from migration. Migrant workers with secondary school education or higher are more likely to be in skilled or semiskilled jobs and to earn higher wages. In general, female migrants earn less than their male counterparts, due to the sector and occupation of employment as well as wage discrimination (Jampaklay and Kittysuksathit 2009; Chantavanich and Vungsiriphisal 2012; Harkins, Lindgren, and Suravoranon 2017; UN Women 2017).

Among internal migrants, the poorest households might lack the resources and monetary and social networks to migrate safely. Those migrating in response to a shock, which makes their primary livelihood untenable, are particularly vulnerable, because they move without much planning or many resources (Pattison et al. 2016b). An ILO survey of internal migrants in 14 states and regions found that migrants from poorer households and households with high levels of debt were more likely to be in situations of forced labor or human trafficking. Children from poorer households were particularly vulnerable to exploitation and human trafficking (ILO 2015a). Qualitative research indicates that extremely poor households sometimes made the decision for their children to migrate as a coping mechanism. Where parents received an advance on wages, the children were effectively bonded to their employers (Deshingkar, Litchfield, and Ting 2019). 
Many international migrants opt for irregular channels. Regular channels for migration take more time and cost more, increasing the incentive for international migrants to opt for irregular channels. Restrictive policies for certain countries, occupations, and certain groups (for example, women) can drive aspiring migrants to use irregular channels (Napier-Moore 2017), and women and ethnic minorities are more likely to rely on them (Harkins, Lindgren, and Suravoranon 2017). A 2018 survey found that 97 percent of the surveyed Myanmar migrants working in the agricultural sector in Thailand had used irregular channels to migrate. Slightly over half had a legal work permit (Harkins 2019).

Although irregular channels are cheaper than regular channels, they are also riskier. For instance, a 2016 survey found that it took Myanmar migrants to Malaysia and Thailand only about 30 days and US\$536 to migrate through irregular channels, compared with 45 days and US\$794 through regular channels. At the same time, 45 percent of those migrating through irregular channels reported facing some problems, relative to 24 percent who moved through regular channels (Harkins, Lindgren, and Suravoranon 2017).

A large number of Myanmar's international migrants are undocumented. According to the 2014 Census, 90 percent of international migrants move to China, Malaysia, and Thailand, compared to just 7 percent moving to Japan, Korea, and Singapore. Migration to the former destinations is largely irregular. Fifty-six percent of migration to Malaysia and 91 percent to Thailand is estimated to be through irregular channels. ${ }^{22}$ The long, porous borders with China and Thailand, as well as the weak enforcement of labor and migration laws in destination countries, make irregular migration to these destinations feasible. Migrants to these destinations tend to be low-skilled, and many have extensive social networks (primarily in Thailand, especially those from Myanmar's border states). Migration to Korea, Japan, and Singapore is largely regular and more expensive, with more cumbersome procedures and greater reliance on brokers and recruitment agencies. However, these destinations are also safer and offer higher wages (ILO 2015b; Department of Population 2016; Min Zar Ni 2018; World Bank and CESD 2018).

Irregular migrants do not have access to the protections afforded by regular migration channels, leaving them vulnerable to exploitation. For instance, irregular migrants do not receive any pre-departure training or support for ensuring that employment contracts are fair. Irregular migrants also lack mechanisms to hold recruitment agents or brokers responsible, have no access to complaint mechanisms, and are often unaware of and wary of seeking out government assistance (Harkins, Lindgren, and Suravoranon 2017; Napier-Moore 2017). Undocumented migrants also face greater job and personal insecurity. Attempts by destination countries to crack down on irregular migrants further increase their risk of failed migration. For instance, changes in regulations in Thailand in 2014 and 2017 led employers to dismiss irregular migrants and forced many irregular migrants to return to Myanmar to avoid arrest. Irregular migrants often need to make informal payments to the local police for advance warning and to avoid deportation and arrest (Thanasombat 2004; Jampaklay and Kittysuksathit 2009; Chantavanich and Vungsiriphisal 2012; Harkins, Lindgren, and Suravoranon 2017; Harkins 2019). 
There is some evidence that irregular migrants earn lower wages than regular migrants, and so gain less from migration. For instance, a survey of Myanmar migrants in three Thai provinces found that 76 percent of workers with completed national verification and passports earned more than THB8,000 (approximately US\$244), compared to only 30 percent of temporary annual workers; no migrants without work permits earned as much (Soe Lin Aung 2014). A 2013 migrant survey in Thailand also found migrants with full or temporary documentation earned higher incomes on average, relative to undocumented workers. Of those earning less than the minimum wage, two-thirds were undocumented (IOM and ARCM 2013). Another survey of return migrants crossing the Myanmar-Thai border found that migrants with documentation were more likely to be paid above the average minimum daily wage, whereas undocumented migrants (holding either a temporary passport or no documents) were more likely to be paid less than the minimum wage (IOM 2019). Low wages were particularly common in sectors like agriculture or forestry and domestic work. Poor quality jobs and low wages were the main reasons that respondents reported a deteriorating financial situation.

The extensive use of informal channels for remittances also represents a loss to migrants and to the country as a whole. Given that informal remittances accounted for more than half of total remittances in 2015 (per official estimates), this preference for informal channels is a lost opportunity in terms of financial inclusion. ${ }^{23}$ There is some evidence that irregular migrants were more inclined to use informal channels for remittances, because they are unable to open bank accounts in their destinations without documentation. ${ }^{24}$

Despite restrictions on their movement, women continue to migrate but often use irregular channels. ${ }^{25}$ Although officially allowed to migrate only in 2009 , Thailand's migrant registration drive in 2001 revealed Myanmar female migrants accounted for nearly 80 percent of all migrant domestic workers (Thanasombat 2004). More recently, official statistics indicate that women accounted for about 20 percent of Myanmar's documented migrant workers in 2014. However, the 2014 Census estimates that women constitute about 38 percent of international migrants, indicating a considerable share of irregular women migrants. The estimate of Myanmar domestic workers in Singapore alone was approximately 40,000 in 2016, an estimated increase of 50 percent over 2014-15 (Napier-Moore 2017). An ILO study of aspiring migrants in three states and regions indicates that women were far more likely to use irregular channels relative to men; many more men planned to use brokers and recruitment agencies as they had more opportunities for high wage employment and regular migration (ILO 2015b).

Migrant domestic workers face insecurity and exploitation, as well as additional costs, following the ban on migrating for domestic work. Some licensed recruiters signed up domestic workers illegally by not registering them with the Myanmar government or by

\footnotetext{
23 A 2013 survey suggests that remittance recipients are more likely to be financially included than the general population, but much of their access is to informal sources (UNCDF 2017).

24 International evidence also suggests that the legal status of migrants impacts the use of remittances. For instance, in Cambodia households with regular migrants tend to use remittances for savings and investment, whereas households with irregular migrants spend more on day-to-day consumption and health expenses as well as debt repayment (Puricelli 2017). However, this could be linked to the fact that poorer households, who are more likely to use remittances for meeting subsistence needs, are more likely to lack resources and the networks to migrate through regular channels.

25 This also appears to be the case internationally, where restrictions on movement have not significantly impeded migration for women from Bangladesh, India, Indonesia, Nepal, and Sri Lanka (Napier-Moore 2017).
} 


\section{References}

Adams, Richard H., and John Page. 2005. Do international migration and remittance reduce poverty in developing countries? World Development 33(10): 1645-69.

ADB (Asian Development Bank). 2013. "Facilitating Safe Labor Migration in the Greater Mekong Subregion: Issues, Challenges, and Forward-looking Interventions." Asian Development Bank, Mandaluyong City, Philippines.

Akee, Randall, and Kapur, Devesh. 2017. "Myanmar Remittances." Ministry of Planning and Finance (MOPF) and International Growth Center (IGC), Yangon.

Anderson, Bridget. 2016. "Worker, Helper, Auntie, Maid? Working Conditions and Attitudes Experienced by Migrant Domestic Workers in Thailand and Malaysia." ILO, Bangkok.

Asis, Maruja M. B. 2006. Living with Migration: Experiences of left-behind children in the Philippines. Asian Population Studies 2(1):45-67.

Bai, Yu, Linxiu Zhang, Chengfang Liu, Di Mo, and Scott Rozelle. 2018. "Effect of Parental Migration on the Academic Performance of Left Behind Children in North Western China," The Journal of Development Studies 54(7):1154-70.

Battistella, Graziano, and Cecilia G. Conaco, M.C. 1998. "The Impact of Labour Migration on the Children Left Behind: A Study of Elementary School Children in the Philippines." Journal of Social Issues in Southeast Asia 13(2):220-41.

Boutry, Maxine, Khin Pyae Sone, Sung Chin Par, and Tin Myo Win. 2016. "Land Dynamics and Livelihoods in Peri-Urban Yangon: The Case of Htantabin Township." In: GRET Studies: Understanding Rural Land Issues to Engage Comprehensive Policy Dialogue in Myanmar. GRET-LIFT, Yangon.

Chang, Fang, Yaojiang Shi, Amber Shen, Asa Kohrman, Katherine Li, Qingqin Wan, Kaleigh Kenny, and Scott Rozelle. 2018. "Understanding the Stituation of China's Left-Behind Children: A Mixed-Methods Analysis," The Developing Economies 57(1):3-35.

Chantavanich, Supang, and Premjai Vungsiriphisal. 2012. "Myanmar Migrants to Thailand: Economic Analysis and Implications to Myanmar Development." In: Lim H \& Yamada Y (eds.) Economic Reforms in Myanmar: Pathways and Prospects. Bangkok Research Centre Research Report 10. Bangkok.

CSO (Central Statistical Organization), UNDP (United Nations Development Program), and World Bank. 2018. "Myanmar Living Conditions Survey 2017: Key Indicators Report," Nay Pyi Taw and Yangon: Ministry of Planning and Finance, UNDP, and World Bank. 
CSO (Central Statistical Organization), UNDP (United Nations Development Program), and World Bank. 2019. "Myanmar Living Conditions Survey 2017: Poverty Report," Nay Pyi Taw and Yangon: Ministry of Planning and Finance, UNDP, and World Bank.

Cuecuecha, Alfredo, and Richard H. Adams. 2016. "Remittances, Household Investment and Poverty in Indonesia." Journal of Finance and Economics 4(3):12-31.

Cunningham, Wendy, and Rafael Muñoz. 2018a. Myanmar Future Jobs: Embracing Modernity. Yangon: World Bank.

Cunningham, Wendy, and Rafael Muñoz. 2018b. Myanmar Future Jobs: Embracing Modernity: Overview. Yangon: World Bank.

de Brauw, Alan, and John Giles. 2018. "Migrant Labor Markets and the Welfare of Rural Households in the Developing World: Evidence from China." The World Bank Economic Review 32(1):1-18.

de Haas, Hein. 2001. "Migration and Agricultural Transformations in the oases of Morocco and Tunisia." KNAG, Utrecht.

De, Supriyo, Ergys Islamaj, M. Ayhan Kose, and S. Reza Yousefi. 2019. "Remittances over the business cycle: Theory and evidence." Economic Notes 48(3):e12143.

Debnath, Priyanka. 2016. "Leveraging Return Migration for Development: The Role of Countries of Origin A Literature Review." KNOMAD Working Paper 17.

Department of Population. 2016. Thematic Report on Migration and Urbanization: Census Report Volume 4-D. Department of Population, Ministry of Labor, Immigration and Population, Republic of the Union of Myanmar.

Deshingkar, Priya, Julie Litchfield, and Wen-Ching Ting. 2019. "Capitalising Human Mobility for Poverty Alleviation and Inclusive Development in Myanmar (CHIME)." International Organization for Migration, Yangon.

De Vreyer, Philippe, Flore Gubert, and Anne-Sophie Robilliard. 2009. "Return Migrants in Western Africa: Characteristics and Labour Market Performance." Document de Travail. Developpment Institutions \& Analyses de Long terme.

Dustmann, Christian, and Oliver Kirchkamp. 2002. "The optimal migration duration and activity choice after re-migration." Journal of Development Economics 67(2):351-72.

Eversole, Robyn, and Mary Johnson. 2014. "Migrant remittances and household development: an anthropological analysis." Development Studies Research 1(1):1-15. 
Filipski, Mateusz, Ben Belton, and Joanna Van Asselt. 2018. "Agricultural Mechanization in the Dry Zone of Myanmar." Policy Note 21, ReSAKSS Asia. IFPRI, Washington, D.C.

Filipski, Mateusz, Hak Lim Lee, Aung Hein, and Ulrike Nischan. 2019. "Emigration and Rising Wages in Myanmar: Evidence from Mon State," The Journal of Development Studies 1-18.

Forbes, Eben. 2019. "Migration, Informal Settlement, and Government Response: The Cases of Four Townships in Yangon, Myanmar." Recherche en sciences humaines sur l'Asie du Sud-Est 33.

Freeman, Janice, Taylor O'Connor, and Ania Zongollowicz. 2018. "Urbanization and Conflict in Myanmar: A briefing paper." Search for Common Ground.

Gao, Yang, Li Ping Li, Jean Hee Kim, Nathan Congdon, Joseph Lau, and Sian Griffiths. 2010. "The impact of parental migration on health status and health behaviours among left behind adolescent school children in China," BMC Public Health 10:1-10.

Gazdar, Haris. 2003, "A Review of Migration Issues in Pakistan." Paper presented at the Regional Conference on Migration, Development and Pro-Poor Choices in Asia, June 22-24, Dhaka.

Graham Elspeth, Lucy P. Jordan, and Brenda S.A. Yeoh. 2015. "Parental migration and the mental health of those who stay behind to care for children in South-East Asia." Social Science \& Medicine 132:225-35.

Griffiths, Michael P. 2016. "Formal Sector Internal Migration in Myanmar." In: Griffiths M \& Ito M (eds.) Migration in Myanmar: Perspectives from Current Research. Yangon.

Gröger, André, and Yanos Zylberberg. 2016. "Internal Labor Migration as a Shock Coping Strategy: Evidence from a Typhoon." American Economic Journal: Applied Economics 8(2):123-53.

Gupta, Shagun. 2016. “Leveraging Migration for Development: A Review of Literature on Patterns and Movements in Myanmar." In: Griffiths M \& Ito M (eds.) Migration in Myanmar: Perspectives from Current Research. Yangon.

Harkins, Benjamin. 2019. Thailand Migration Report 2019. United Nations Thematic Working Group on Migration in Thailand, Bangkok.

Harkins, Benjamin, Daniel Lindgren, and Tarinee Suravoranon. 2017. "Risks and rewards: Outcomes of labour migration in South-East Asia." International Labour Organization (ILO) and International Organization for Migration (IOM), Bangkok.

Iheke, O. R. 2014. "Impact of Migrant Remittances on the Output of Arable Crop of Farm Households in South Eastern Nigeria." American Journal of Experimental Agriculture 4(10):1209-18.

Ilahi, Nadeem. 1999. "Return Migration and Occupational Change." Review of Development Economics 3(2):170-86.

ILO (International Labour Organization). 2015a. "Internal Labour Migration in Myanmar: Building an Evidence-base on Patterns in Migration, Human Trafficking and Forced Labour." International Labour Organization, Yangon. 
ILO (International Labour Organization). 2015b. "Safe Migration Knowledge, Attitudes and Practices in Myanmar. Tripartite Action to Protect the Rights of Migrant Workers within and from the Greater Mekong Subregion (GMS TRIANGLE project)." International Labour Organization, Bangkok.

Imai, Katsushi S., Raghav Gaiha, R., Abdilahi Ali, and Nidhi Kaicker. 2014. "Remittances, growth and poverty: New evidence from Asian countries." Journal of Policy Modeling 36(3):524-38.

IOM (International Organization for Migration). 2019. "Flow Monitoring Surveys: Insights into the Profiles and Vulnerabilities of Myanmar Migrants to Thailand (Round Three)." International Organization for Migration, Bangkok.

IOM (International Organization for Migration) and ARCM (Asian Research Center for Migration). 2013. "Assessing Potential Changes in the Migration Patterns of Myanmar Migrants and Their Impacts on Thailand." International Organization for Migration and Asian Research Center for Migration, Chulalongkorn University, Bangkok.

IOM (International Organization for Migration) and ARCM (Asian Research Center for Migration). 2015. "Supplementary Report: Assessing Potential Changes in the Migration Patterns of Myanmar Migrants and Their Impacts on Thailand." International Organization for Migration and Asian Research Center for Migration, Chulalongkorn University, Bangkok.

Jampaklay, Aree, and Sirinan Kittysuksathit. 2009. "Migrant Workers' Remittances: Cambodia, Lao PDR and Myanmar." ILO/Japan Project on Managing Cross-border Movement of Labour in Southeast Asia, Bangkok.

Jirattikorn, Aamporn. 2015. "Managing Migration in Myanmar and Thailand: Economic Reforms, Policies, Practices and Challenges." Trends in Southeast Asia 9.

Jonkers, Koen. 2008. "A Comparative Study of Return Migration Policies Targeting the Highly Skilled in Four Major Sending Countries." MIREM Analytical Report 2008/05, European University Institute, Florence.

Kabeer, Naila. 1999. "Resources, Agency, Achievements: Reflections on the Measurement of Women's Empowerment." Development and Change 30(3):435-64.

Kakuli, Anna, and Viveka Risberg. 2012. "A Lost Revolution? Empowered but Trapped in Poverty: Women in the Garment Industry in Bangladesh Want More." Swedwatch Report No. 47. Stockholm: Swedwatch.

Khin Soe Kyi. 2018. "The Impact of Migration Works on the Socioeconomic of Left-behind Families of Myanmar Migrant Workers." In: 2nd International Conference on Burma/Myanmar Studies, University of Mandaly (Myanmar), Co-hosted by Chiang Mai University (Thailand)

Knodel, John. 2013. "The Situation of Older Persons in Myanmar: Results from the 2012 Survey of Older Persons." HelpAge International, Yangon.

Knodel, John, Wiraporn Pothisiri, Chanettee Milintangul, and Busarin Bangkaew. 2015. "Leaving Children with Grandparents in Myanmar: Experiences and Perceptions of Migrants in Samut Sakhon Province in Thailand." College of Population Studies, Chulalongkorn University, Bangkok 
Konseiga, Adama. 2004. "Adoption of agricultural innovations in the Sahel: the role of migration in food security." Germany: University of Bonn. Unpublished manuscript, Center for Development Research (ZEF)

Kubo, Koji. 2017. "Evolving Informal Remittance Methods of Myanmar Migrant Workers in Thailand." Journal of the Asia Pacific Economy 22(3):396-413.

Kyan Htoo, and Aye Myintzu. 2016. "Rural-Urban Migration around Yangon City, Myanmar." Food Security Policy Project Research Highlights. Michigan State University, East Lansing.

Kyed, Helen Maria. 2017. "Migration and Security Challenges in Yangon's Informal Settlements: The Case of Hlaing Thayar Township." Report for the Danish Institute for International Studies.

Lahaie, Claudia, Jeffrey A. Hayes, Tinka Markham Piper, and Jody Heymann. 2009. “Work and family divided across borders: The impact of parental migration on Mexican children in transnational families." Community, Work \& Family 12(3):299-312.

Lam, Theodora, and Brenda S. Yeoh. 2018. "Migrant mothers, left-behind fathers: the negotiation of gender subjectivities in Indonesia and the Philippines." A Journal of Feminist Geography 25(1):104-17.

Lucas, Robert E. B. 2004. "International Migration Regimes and Economic Development." Draft report to the Expert Group on Development Issues, Swedish Ministry for Foreign Affairs.

Ma, Alex. 2017. "Labor Migration from Myanmar: Remittances, Reforms, and Challenges. Migration Policy Institute.

Maharjan, Amina, Siegfried Bauer, and Beatrice Knerr. 2012.“Do Rural Women Who Stay Behind Benefit from Male Out-migration? A Case Study in the Hills of Nepal." Gender Technology and Development 16(1):95-123.

Maharajan, Amina, and Theingi Myint. 2015. "Internal Labor Migration Study: In the Dry Zone, Shan State and the Southeast of Myanmar." HELVETAS Swiss Intercooperation Myanmar, Yangon.

Majid, Nomaan. 2000, "Pakistan: Employment, Output and Productivity." Issues in Development Discussion Paper 33. International Labour Office, Geneva.

McCormick, Barry, and Jackline Wahba. 2004. "Return International Migration and Geographical Inequality: The Case of Egypt." Journal of African Economies 12(4):500-32.

Meyer, Sarah R., Michele R. Decker, Wietse A. Tol, Nada Abshir, Aye Aye Mar, and W. Courtland Robinson. 2015. "Workplace and Security Stressors and Mental Health among Migrant Workers on the Thailand-Myanmar Border." Social Psychiatry and Psychiatric Epidemiology 51:713-23.

Min Zar Ni. 2018. "Cause and Consequence of International Migration: The Case of Mon State, Myanmar." CESD, Yangon.

Mishra, Prachi. 2014. "Emigration and Wages in Source Countries: A Survey of the Empirical Literature." In International Handbook on Migration and Economic Development, edited by Robert E. B. Lucas, 241-66. Cheltenham, U.K.: Edward Elgar Publishing. 
MMN (Mekong Migration Network). 2016. "Permanently Temporary: Examining the Impact of Social Exclusion on Mekong Migrants." Mekong Migration Network (MMN), Bangkok.

Mya Mya Thet, and Piriya Pholphirul. 2016. "The Perception of Myanmar Development on its Return Migrants: Implications for Burmese Migrants in Thailand." Journal of International Migration and Integration 17(4):995-1014.

Napier-Moore, Rebecca. 2017. "Protected or Put in Harm's Way? Bans and Restrictions on Women's Labour Migration in ASEAN Countries." ILO and UN Women.

Nyi Nyi. 2013. "Levels, Trends and Patterns of Internal Migration in Myanmar." Department of Population, Nay Pyi Taw.

Olmedo, Alexandra, and José Ernesto López Córdova. 2006. "International Remittances and Development: Existing Evidence, Policies and Recommendations", INTAL-ITD Working Paper, Nr. 41, Institute for the Integration of Latin America and the Caribbean e Integration, Trade and Hemispheric Issues Division.

Pattison, C., Voss, J., Woodhouse, A., Zurstrassen, M., 2016a. "A Country on the Move: Migration Networks and Risk Management in Two Regions of Myanmar." In: Griffiths M \& Ito M (eds.) Migration in Myanmar: Perspectives from Current Research. Yangon.

Pattison, C., Voss, J., Woodhouse, A., Zurstrassen, M., 2016b. "A Country on the Move: Migration Networks and Risk Management in Two Regions of Myanmar." World Bank, Yangon.

Puricelli, Francesca. 2017. "Migrating Towards A Better Future A Qualitative Study On Migration Choices And Outcomes In Cambodia." Lund University.

Rutkowski, Jan. 2014. "Do Myanmar Workers Have the Skills That Employers Seek?"

Sakka, Despina, Maria Dikaiou, and Grigoris Kiosseoglou. 1999. "Return Migration: Changing Roles of Men and Women." International Migration 37(4):741-64.

Saw Yu May, 2015. "Migration as a Challenge for Myanmar's Socio-Economic Development: Case Studies of Hpa-An and Mrauk-U townships in Myanmar." In: International Conference on "Burma/Myanmar in Transition: Connectivity, Changes and Challenges", University Academic Service Centre (UNISERV), Chiang Mai University, Thailand.

Soe Lin Aung, 2014. "The Friction of Cartography: On the Politics of Space and Mobility among Migrant Communities in the Thai-Burma Borderlands." Journal of Borderlands Studies 29, 27-45.

Sunpuwan, Malee, and Sakkarin Niyomsilpa. 2012. "Perception and Misperception: Thai Public Opinions on Refugees and Migrants from Myanmar." Journal of Population and Social Studies 21(1) 47-58.

Teerawichitchainan, Bussarawan, and John Knodel. 2019. "Impacts of Parental Migration on Children Left Behind in Myanmar: Evidence from a Recent Survey in Myanmar's Dry Zone." In: Paper presented at the Population Association of America (PAA) Annual Meeting 2019. 
Teerawichitchainan, Bussarawan, and John Knodel. 2017. "Impacts of Migration on Households in the Dry Zone, Myanmar." In: University of Michigan Population Studies Center Research Report 17-882.

Testaverde, M., H. Moroz, C. H. Hollweg, and A. Schmillen. 2017. Migrating to Opportunity: Overcoming Barriers to Labor Mobility in Southeast Asia. World Bank, Washington, DC.

Than Pale. 2018. "Justice-Seeking Strategies in Everyday Life: Case Study among Urban Migrants in Yangon." Independent Journal of Burmese Scholarship 1, 151-179.

Thanasombat, Sirithon. 2004. "Vulnerabilities and Visibility: Thailand's Management of Female Domestic Workers from Burma." Journal of Public and International Affairs 15.

Turnell, Sean. 2014. "Banking and Financial Regulation and Reform in Myanmar." Journal of Southeast Asian Economies 31(2):225-40.

Turnell, Sean, Alison Vicary, and Wylie Bradford. 2008. "Migrant-Worker Remittances and Burma: An Economic Analysis of Survey Results." In: Skidmore M \& Wilson T (eds.) Dictatorship, Disorder and Decline in Myanmar. Australian National University E Press, Canberra, Australia.

UNCDF (United Nations Capital Development Fund). 2017. "Remittances as a Driver of Women's Financial Inclusion in the Mekong Region." UNCDF, New York.

UN ESCAP (United Nations Economic and Social Commission for Asia and the Pacific). 2017. "Towards Safe, Orderly and Regular Migration in the Asia-Pacific Region: Challenges and Opportunities." ESCAP, Bangkok.

UN Women. 2017. "Women Migrant Workers in the ASEAN Economic Community." ASEAN Secretariat Jakarta.

University of Sussex and IOM (International Organization for Migration). 2017. "Highlight of Preliminary Study Findings: Capitalising Human Mobility for Poverty Alleviation and Inclusive Development in Myanmar (CHIME)." Presentation to LIFT, Yangon.

Wahba, Jackline. 2004. “Does International Migration Matter? A Study of Egyptian Return Migrants." In Arab Migration in a Globalized World, 179-200. Geneva: International Organization for Migration.

World Bank 2006. Global Economic Prospects Economic Implications of Remittances and Migration. Washington D.C.: World Bank.

World Bank. 2016. Migration and Development: A Role For the World Bank Group. Washington, D.C.: World Bank.

World Bank. 2019a. Myanmar's Urbanization: Creating Opportunities for All. Yangon: World Bank.

World Bank. 2019b. World Bank Analysis of MLCS.

World Bank. 2019c. Myanmar: Economic Transition amid Conflict: A Systematic Country Diagnostic. Yangon: World Bank. 
World Bank and CESD (Centre for Economic and Social Development). 2018. "Rapid Field Assessments in Ayeyarwady, Bago, Magwe, Mandalay, Mon, Kayin, Tanintharyi and Yangon." World Bank, Yangon.

Yang, Dean. 2004. "International Migration, Human Capital, and Entrepreneurship: Evidence from Philippine Households with Members Working Overseas." Ann Arbor, MI: School of Public Policy, University of Michigan.

Yang, Dean, and Hwa Jung Choi. 2007. "Are Remittances Insurance? Evidence From Rainfall Shocks in the Philippines." World Bank Economic Review 21(2):219-48.

Yi, Soonwha. 2018. "Labor Migration: Impact on Origin Countries. A Literature Review." Background paper.

Yoshino, Naoyuki, Farhad Taghizadeh-Hesary, and Miyu Otsuka. 2017. "International Remittances and Poverty Reduction: Evidence from Asian Developing Countries." ADBI Working Paper 759. Tokyo: Asian Development Bank Institute. 


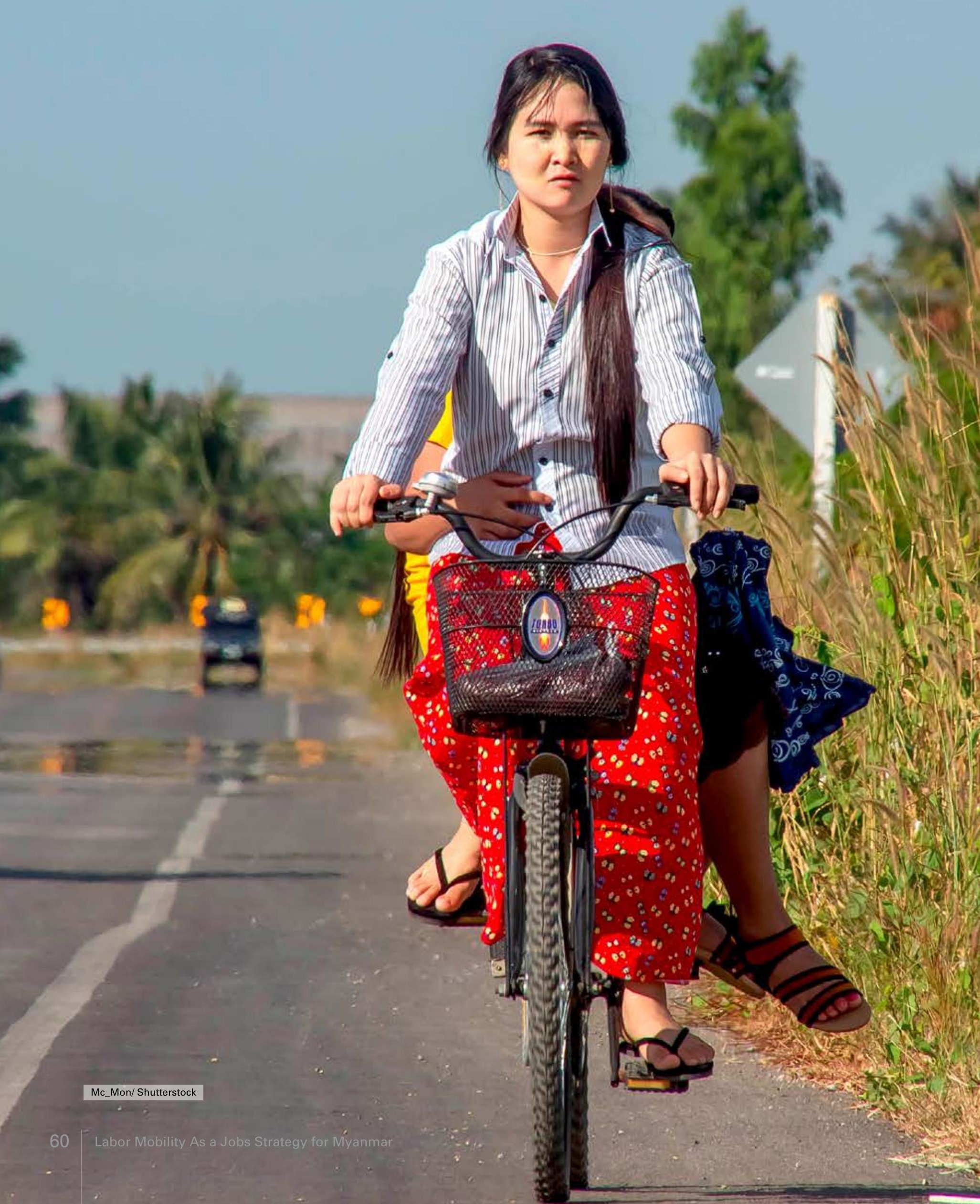




\section{CHAPTER \\ Active Labor Market Policies for Myanmar Workers in Myanmar}

M yanmar has made progress in developing the infrastructure necessary to deliver active labor market policies (ALMPs), but there are several areas for improvement. Many ministries, including the Ministry of Labor, Immigration, and Population (MOLIP), provide short skills training courses. However, the effectiveness of those courses tends to be limited by curricula that are not standardized and that do not reflect the needs of industry, especially for high technology. Most of the skills training courses are not linked to other employment services provided by MOLIP. Human and financial resource constraints make the delivery of employment services by Labor Exchange Offices (LEOs) challenging. Although only mandated to provide employment services, LEO staff must serve many other functions, and that mandate strains staff who are already overburdened. This makes coordination with the private sector and with the civil society organizations (CSOs), nongovernmental organizations (NGOs), and international development agencies that deliver ALMPs challenging. Labor market information is limited in type and in dissemination. The LEOs' labor market information function is generally confined to entering jobseeker and vacancy registration information onto forms and into a database. This function does not include seeking out employers who are hiring, projecting employment and skill needs, informing jobseekers about training programs, or identifying overseas employment opportunities. Labor market information is publicized primarily in the form of vacancies posted on physical job boards at the LEOs and on the job search website of the Department of Labor, which at times suffers from poor functionality. Awareness and use of the website appear to be limited. This means that the labor market information that is available is not widely viewed. LEOs are responsible for providing public job-matching and -placement services, but time and resource constraints undermine the effective and efficient delivery of those services. At the same time, there may be space for the Department of Labor and for LEOs to take a more active role in managing private providers of job-matching and -placement services. 


\section{Introduction}

ALMPs provide information and support for finding jobs, including to people moving to areas of opportunity. This chapter discusses ALMPs in Myanmar as the framework of support for jobseekers overall and for people migrating for jobs domestically, in particular.

The objective of ALMPs is to generate more and better employment opportunities for workers. There are a variety of different instruments that achieve this objective, ranging from the provision of basic information about the health of the labor market to the coaching of jobseekers about the job openings that are suitable for their qualifications. These services are provided by both public and private actors. Public actors typically focus on less-skilled individuals and jobs, and private actors focus on more highly skilled individuals and jobs. As described in the Introduction, public action is most likely to be effective where market failures lead to inefficiencies in the labor market. CSOs, NGOs, and international development agencies also provide services associated with active labor market policies and they, like public providers, tend to focus on the less skilled.

This chapter focuses on four main types of ALMPs, which follow the framework described in the Introduction. First, training is designed to improve the employability of jobseekers by helping them obtain skills that are relevant in the labor market. This includes training in technical skills, in soft skills, and in digital or technology-specific skills. The focus of this report is on shortcourse training that excludes secondary and post-secondary technical and vocational education and training (TVET). Second, labor market information about labor demand, labor supply, labor market intermediaries, labor market policy, and labor conditions helps jobseekers find and obtain jobs; it is also useful for labor market stakeholders, like employers, educational institutions, and training providers, who use this information to inform decision making. Third, job matching and placement services actively seek to match individual jobseekers to individual jobs. Such services evaluate jobseekers' qualifications against the qualifications required by job vacancies and then inform the jobseeker or the employer of the match-or they take an active role in making the match between the jobseeker and the employer. Finally, the financial assistance offered includes policies that help alleviate capital constraints to obtaining jobs, such as subsidies for job searching or employment. These different areas of ALMPs often overlap. For instance, labor market information is a key input to designing effective skills-training programs.

This chapter first introduces the legal and institutional framework for ALMPs in Myanmar. The four primary areas of ALMPs—training, labor market information, job matching and placement, and financial assistance-are then discussed in turn, with individual sections for labor market information and job matching and placement. The chapter concludes with a discussion of areas that need improvement and of potential gaps.

1 Outsourcing services are not covered in this report. Such services are available informally in Myanmar (they are not recognized by law), but the extent to which they are offered is not known. 


\section{Legal and institutional framework}

Two main laws govern the provision of ALMPs in Myanmar. The Employment and Skills Development Law (2013) (ESD Law) permits the establishment of LEOs, which are the main providers of ALMPs in Myanmar. The ESD Law also promotes job matching, governs employment contracts, and promotes skills development, including through vocational training centers and a skills-development fund. ${ }^{2}$ The Employment Restriction Act (1959) lays out procedures for the registration of jobseekers and vacancies, and for matching jobseekers to vacancies. The Act authorizes the Department of Labor to license local private recruitment agencies involved in job placement within Myanmar. ${ }^{3}$ A new law is under discussion that would develop the TVET system, strengthen its governance, promote private-sector engagement in skills development, and expand demandresponsive TVET programming (UNESCOUNEVOC International Centre 2018).

A variety of public, private, and nonprofit actors provide ALMPs in Myanmar. Figure 2.1 shows the different providers of ALMPs in Myanmar and the different types of services they provide. As will be discussed later in the chapter, financial assistance is generally not provided, which is why the figure does not include it. Each type of actor provides training in the form of short courses, while the provision of labor market information and job matching and placement varies by actor, with some providing both services and others providing only job matching and placement.

MOLIP is responsible for managing ALMPs in Myanmar. ${ }^{4}$ The Ministry's Department of Labor coordinates this management primarily through its Employment Division, but also through its Skill Development Division, which provides training courses. Other divisions within the Department of Labor, and other departments within MOLIP, are involved in additional aspects of labor regulation and enforcement. At the state and region level, 15 state and region Department of Labor offices assist with the management of jobseekers. ${ }^{5}$ In theory, these offices should have an organizational structure that mirrors the 7 divisions of the Union 's Department of Labor.. At the local level, LEOs, under the Employment Division and managed via the state and region Department of Labor offices, are responsible for the provision of public employment services to jobseekers. In practice, however, the state and region offices, and the LEOs they manage, fulfil the functions of all of the Department of Labor's divisions. This means that LEOs' tasks include oversight of labor law and maintenance of labor relations, in addition to the provision of employment services, such as registration of jobseekers and vacancies.

\footnotetext{
2 The skills-development fund has not yet been implemented.

3 Many other laws affect employment and labor markets in Myanmar. The Factories Act (1951), as amended in 2016, primarily governs health and safety and working hours; the Social Security Law (2012) and the Workmen's Compensation Act (1923), as amended in 2005, govern compensation for injury and illness and other benefits; the Settlement of Labor Disputes Law (2012), as amended in 2014, primarily governs labor dispute resolution, while the Labor Organization Law (2011) governs labor relations; the Minimum Wage Law (2013) governs the setting and payment of the minimum wage, while the Payment of Wages Law (2016) governs the payment of wages; the Shops and Establishments Law (2016) governs working hours, wages, and safety and health in shops and establishments; and the Leave and Holidays Act (1951), as amended in 2014, governs public holidays and leave (Luther 2017; ILO 2017).

4 MOLIP was formed from the merger of the Ministry of Labor, Employment, and Social Security and the Ministry of Immigration and Population in 2016

5 The directors of the state and region Department of Labor offices report directly to the Director General of the Department of Labor, while also informing the relevant division in the Department about their activities.
} 
Figure 2.1

The providers of ALMPs in Myanmar

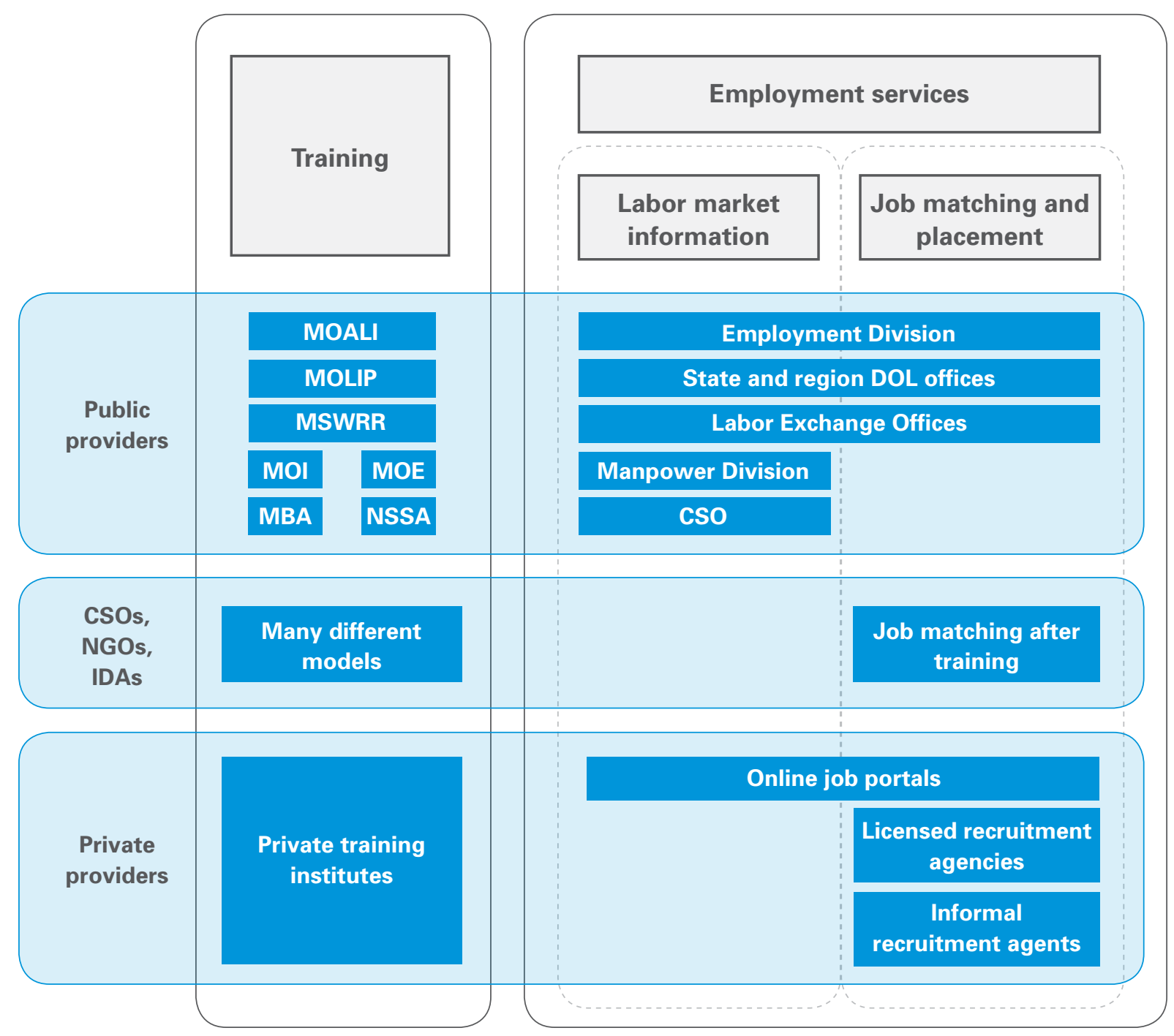

The Employment Division currently manages 83 township LEOs around the country, through the 15 state and region offices of the Department of Labor (See Online Appendix 1 for a list of LEOs.). ${ }^{6}$ The Department of Labor also has officers in Myanmar's three special economic zones. Each state and region's Department of Labor office manages several LEOs, and each LEO generally covers several townships in its surrounding area. The LEOs' main stated responsibility is job matching - to be done through registration of jobseekers, registration of employers and job vacancies-and matching registered jobseekers to registered job vacancies. LEOs are also tasked with encouraging and supporting workers to migrate to other areas, advising jobseekers on how to obtain jobs that match their skills and qualifications, and supporting employers in selecting and recruiting jobseekers. The state and region Department of Labor offices collect data from individual LEOs to report labor statistics to the Union government.

6 However, the LEOs and the state and region Department of Labor offices receive separate budget allocations from the Union government. 
Although the LEOs are supposed to be devoted exclusively to job matching services, in practice they have a broad portfolio and conduct much of the Department of Labor's employmentrelated business at the ground level. In addition to registering internal and international jobseekers, employers, and job vacancies, labor officers at LEOs oversee employment contracts between employers and employees, help resolve labor disputes, oversee unions, monitor compliance with the minimum wage, and facilitate skills-development programs. Additionally, MRCs, which are under the Department of Labor's Migrant Worker Division and provide support to migrants and their family members, are physically located within 11 LEOs. (Chapter 3 provides additional information about MRCs.) Labor officers at these LEOs have been trained by the International Labor Organization (ILO) to deliver support services for migrants, in addition to their LEO tasks. Although LEOs are officially overseen by the Employment Division, their proliferation of functions means that other divisions in the Department of Labor, including the Migrant Worker Division, also play a role in their supervision. Despite their many tasks, LEOs do not play a significant role in overseeing the recruitment of workers, whether internally or internationally.

The delineation of responsibilities in the Magway LEO exemplify the way staff roles are divided. This LEO is authorized to have 16 staff members, but only has 7 . The staff officer is responsible for overseeing all of the LEO's activities, and prepares reports, verifies information, visits worksites where a union may be established, and assists in dispute resolution. The deputy staff officer supports the staff officer in these activities. One upper division clerk is responsible for financial and administrative functions, while the other is responsible for reporting on job-matching services. Two lower division clerks are responsible for data entry and registering jobseekers. ${ }^{7}$ Finally, an assistant is responsible for office logistics.

MOLIP and the Central Statistical Organization are the primary agencies responsible for collecting labor market information. MOLIP conducted the 2014 population census, and the Manpower Division works with the International Labor Organization to field the Myanmar Labor Force, Child Labor, and School-to-Work Transition Survey. The Central Statistical Organization fielded the Myanmar Living Conditions Survey in 2017. MOLIP's LEOs also collect administrative data on jobseekers, job vacancies, and job matches.

Skills training is provided by many different ministries. The Ministry of Education (MOE) and the Ministry of Agriculture, Livestock, and Irrigation (MOALI) provide skills training resulting in formal upper-secondary and post-secondary certifications (which are outside of the scope of this report) (UNESCO 2019). ${ }^{8}$ However, both ministries also provide non-formal, certificate-level courses. The Department of Technical and Vocational Education and Training (DTVET) runs 5 specialized training institutes, as well as short courses at government technical institutes (GTIs) and government technical high schools (GTHSs), both often in collaboration with other local

7 LEO staff collect and report information via a series of forms, which are listed in Online Appendix 2 The upper division clerk's reporting on job-matching services uses LEO Forms 3 and above. The lower division clerks register jobseekers using Form 1 and record the data on Form 2 and in the online information management system.

8 The Department of Technical and Vocational Education and Training (DTVET) in MOE offers upper-secondary TVET in 35 government technical high schools (GTHSs) and a post-secondary diploma in 22 government technical institutes (GTIs) and 3 government technical colleges (GTCS) (UNESCO 2019). These DTVET courses tend to focus on engineering, although an expansion to hospitality and services is underway. The GTI programs are also provided in institutes under the Ministry of Border Affairs. Overall, these TVET courses suffer from limited course selection and poor learning pathways (UNESCO 2019). MOALI runs 15 agricultural institutes and 1 Lacquerware Technical College that provide post-secondary education. 
and international actors. MOALI runs 7 cooperative training schools, 14 weaving and vocational schools, 3 fishery schools, 14 livestock vocational schools, and 1 Livestock Training School. Certificatelevel courses are also provided by MOLIP at 6 Skills Training Centers under the Department of Labor; by the Ministry of Industry at 6 Industrial Training Centers; by the Ministry of Social Welfare, Relief, and Resettlement at several different types of training centers including 11 home science schools and a vocational training school for adults with disabilities; and by the Ministry of Border Affairs at its 42 home science schools, 9 technical schools, and 1 vocational training center.

The National Skills Standards Authority (NSSA), which is an independent body (with MOLIP as its focal ministry), sets qualification standards, promulgates skills standards, and accredits skills-assessment centers. NSSA is responsible for introducing recognition of prior learning approaches for occupational skills assessment and certification, promoting National Occupational Competency Standards, and promoting skills recognition including through the German Development Agency (GIZ)-supported Skills Recognition program (UNESCO 2019). NSSA has established the National Skills Qualification Framework (NSOF) for workers at Supervisor level and below, and identified skill levels from level 1 to level 4 such as "Level 1: Semi-skilled Worker"; "Level 2: Skilled Worker"; "Level 3: Advanced Skilled Worker"; "Level 4: Supervisor." NSSA has developed the National Occupational Competency Standard (NOCS) for 185 occupations and revised the NOCS for 67 of these occupations. There are 181 NSSAaccredited skills-assessment centers in Myanmar to undertake recognition of prior learning, and more than 15,000 NSSA certifications have been awarded in 30 occupational areas as of April 2020.
Outside of the public sector, private recruitment agencies, private training providers, CSOs, NGOs, and international development agencies also provide ALMPs. The public employment services provided by LEOs generally target lessskilled workers. CSOs, NGOs, and international development agencies tend to target this same group of workers and help fill gaps in training, public employment services, and financial assistance-at times in coordination with LEOs, public training institutes, and other public agencies. The services provided by these groups often combine aspects of skills training, job matching and placement, and financial assistance. Private-sector actors are also involved in the provision of training and employment services in Myanmar, although their services tend to be targeted to more highly skilled jobseekers. This is primarily because private sector actors can charge a fee to employers for identifying hard-to-find, skilled workers, while employers would not pay such a fee for lower-skilled workers who are in greater supply. Privately run, online job portals provide labor market information and some job matching-type services. Private firms provide training courses in areas ranging from air conditioning to hospitality to computer training. Private, internal recruitment agencies are licensed by the Department of Labor to facilitate matches between employers and jobseekers. Informal recruitment agents and brokers also facilitate these matches, but do so without a license.

\section{Areas for improvement and potential gaps}

The institutions responsible for delivering ALMPs in Myanmar face human resource constraints. In many cases, these institutions operate with fewer staff than they are permitted. The state and region Department of Labor offices are permitted 
to hire 19 people, but in Ayeyarwady only 6 have been appointed, and in Magway and Tanintharyi, only 7 have been appointed. The township LEOs are permitted to hire 16 people, but in the Dawei Township LEO, only 5 are working in the office; only 6 are working in the Yangon, Pathein, Mawlamyine, and Hpa-An Township LEOs; and only 7 are working in the Magway and Meiktila Township LEOs. This pattern of understaffing is typical of LEOs throughout Myanmar.

Understaffing is exacerbated by the multiple functions performed by LEOs. Anecdotal evidence suggests that a single officer may be responsible for registering jobseekers and job vacancies, compiling the required periodic updates to the Employment Division on jobseekers and job vacancies, overseeing employment contracts, and staffing the MRC. This proliferation of tasks also reflects the situation at the state and region Department of Labor offices, which are meant to have 7 divisions, consistent with those of the Union's Department of Labor, but in practice often combine all of these divisions. For instance, in the Magway Region Department of Labor office, 2 officers oversee the functions of the 7 Department of Labor divisions. LEO staff members are at times burdened with time-consuming administrative tasks related to registering jobseekers and job vacancies and preparing reports. These are largely manual tasks in which the officer first enters the jobseeker's information on a physical form, then copies the information onto a separate physical form, and then enters the information into a digital information system. Unreliable internet access means that the online database entry can take several tries.

Financial resource constraints also inhibit the effectiveness of ALMPs, and they are likely a reason for the understaffing; anecdotal evidence suggests that township LEOs and the state and region Department of Labor offices do not have the resources to hire the necessary staff. Budget constraints can also prevent LEOs from performing their functions, such as hosting job fairs, and providing additional awareness campaigns at the village level.

Finally, there are coordination difficulties in the system for delivering ALMPs. At the local level, state and region Department of Labor offices and LEOs do sometimes coordinate with partners outside of the government, such as hosting job fairs with employers or recruitment agencies. However, outreach to employers about vacancies and skills needs and additional coordination with CSOs, NGOs, and international development agencies delivering ALMPs, could be leveraged to enhance the capacity and improve the quality of publicly provided ALMPs.

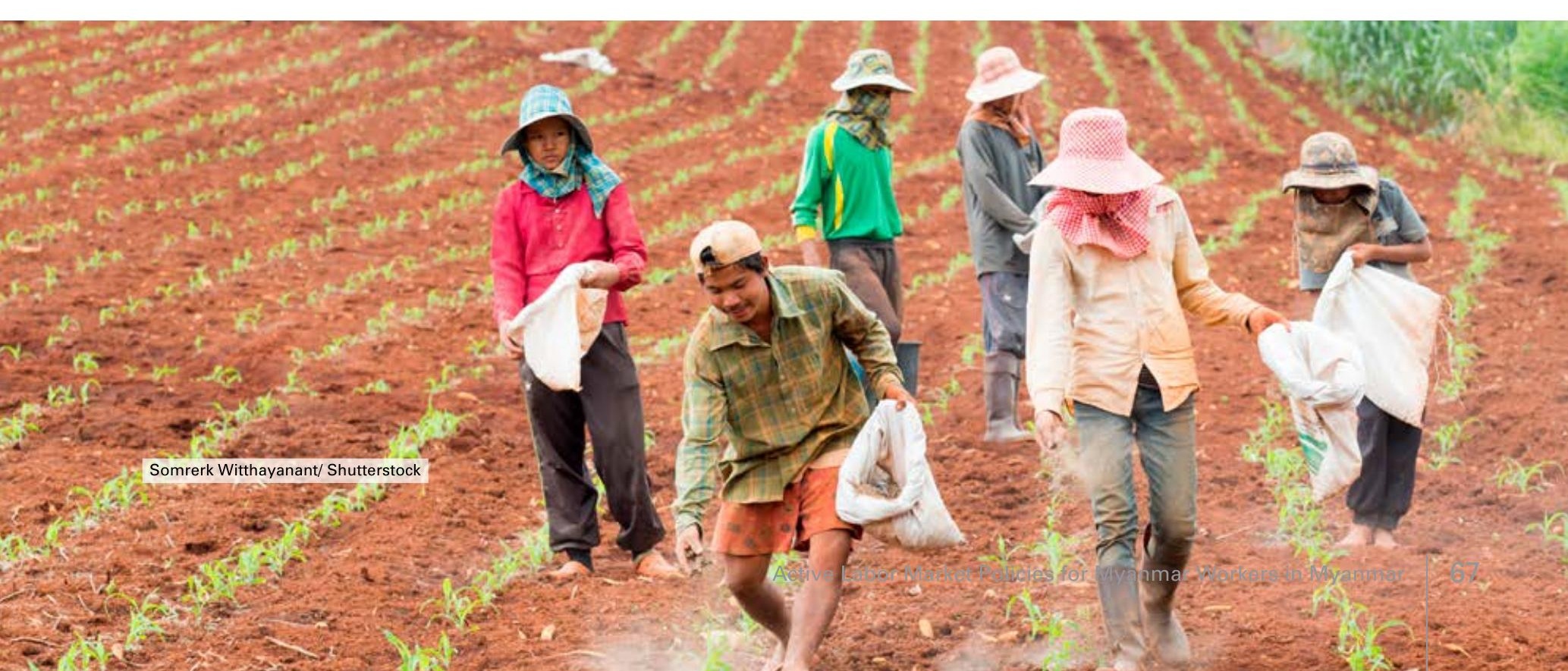




\section{Training}

Jobseekers may lack the skills or qualifications necessary to fill the available vacancies in the labor market. In order to resolve this skills gap, public, private, and nonprofit providers offer training courses for a variety of skills. These courses generally have the objective of making jobseekers attractive to employers seeking to hire in the short term. Programs covered in this section focus on short-term training courses, and do not include formal secondary and post-secondary TVET.

The Ministry of Education (MOE) provides skills training. DTVET in MOE offers competency-based short courses at 5 training institutes in engineering, hospitality and tourism, industrial technology, English, and welding. The institutes are generally set up with local and international collaboration (UNESCO 2019). ${ }^{9}$ Other short courses are offered at DTVET's 35 GTHSs and 22 GTIs. These are offered in collaboration with local and international NGOs and international development partners or by the institutes themselves. ${ }^{10}$ The short courses typically relate to engineering fields, garmentmaking, personal care, and tourism. The institutes offer these courses on an ongoing basis. Duration, training capacity, quality, and curricula are not standardized.

MOALI provides certificate-level TVET at cooperative training schools targeted to post-secondary graduates; at weaving and vocational schools targeted to current workers; at fishery schools targeted to current workers; and at livestock vocational and training schools targeted to current workers (UNESCO 2019). Individual departments under MOALI also provide training. The Department of Rural
Development (DRD) provides livelihoods training by contracting trainers from other departments. In Rakhine State, for example, DRD tailors its training offerings either by asking village administrators what kind of training they would like or by doing a market assessment. DRD advertises the courses to the village heads, and those interested can then apply. The trainings are free, and transportation, and sometimes lunch, is provided. Most of the training offerings are mobile (that is, they are taught in communities and not in formal training centers). These include carpentry and masonry, rural products and technology, electrical wiring, mechanical repair, weaving, computer and internet, livestock and veterinary, basketmaking, concrete, knitting and embroidery, agriculture, sewing, and domestic handicrafts. The Department of Agriculture provides training in agriculture (how to grow rice, peas, and vegetables), in subjects related to nurseries and seedling farms, in protection from pests, and in farming dos and don'ts. The Department uses trained community workers that at times work with NGOs to provide training. The work of these extension workers includes tending to demonstration farming plots. The Department of Livestock provides training on animal husbandry, and township veterinarians and officers give talks each month about animal health and husbandry. The Department of Small Scale Industrial Development (SSID) runs the 14 weaving and vocational schools. SSID also offers training in other areas, such as food processing and mechanics. Finally, the Department of Fisheries also provides training, for example when fishery ponds are installed.

$9 \quad$ These are the Singapore Myanmar Vocational Training Institute (SMVTI), Nyaungshwe Vocational Training Institute (NVTI), School of Industrial Training and Education (SITE), English Language Professional School (ELPS), and Yadanar Welding Training Center (YWTC).

10 Partners providing support include ADRA Myanmar, the Agency for Cooperative and Technical Education Development, the Finnish Refugee Council, the Norwegian Refugee Council, SwissContact, and the Association for Volunteer Service International (UNESCO 2019). 
Several other ministries provide skills training in Myanmar. The Ministry of Industry (MOI) has links to employers, and they provide one-year vocational training at industrial training centers, primarily for jobseekers who have completed upper secondary education (UNESCO 2019). Their training offerings include electronics, engineering repair, and electronic wiring. The Ministry of Social Welfare, Relief, and Resettlement provides TVET to vulnerable young people, people with disabilities, and other vulnerable groups (UNESCO 2019). This ministry provides courses in basic/traditional sewing, baking, cooking of traditional snacks, flower decoration, training in the beauty industry, and how to give pedicures and manicures. The Ministry of Border Affairs provides TVET to women and young people from ethnic minorities at home science schools and technical schools via its Education and Training Department (UNESCO 2019). Training in the women's vocational training schools includes courses in sewing, knitting, bamboo and cane handicrafts, and cooking. Training in the youth technical schools includes courses in carpentry, masonry, iron bar binding, automobile repair, electrical wiring, air conditioner and refrigerator repair, arc welding, and mobile phone repair. MOLIP oversees the reskilling and upskilling of its current employees. The Department of Labor in MOLIP is in the process of developing its skills-training infrastructure. The Department has 6 skills training centers: in Yangon (where there are two), Mandalay, Pathein, Set Sea, and Hpa-An, which are under the Skills Development Division. These centers are responsible for providing training in subjects like electrical installation, construction, and electrical wiring, and at times, they provide mobile training. A skills training center is under construction in Bago Region. Two skills training centers are being planned for construction in Lashio and Sittwe. Finally, the Ministry of Hotels and Tourism provides hotel and tourism training. A partnership between the Ministry of Tourism, international development actors, and the Tourism Association in southern Rakhine State has the potential to be an effective model for training collaboration.

There are many private providers of training in Myanmar, and their offerings are diverse, ranging from small and informal training centers targeted to low-skilled workers in the garment sector to larger training centers offering classes to more highly skilled jobseekers (Milio, Garnizova, and Shkreli 2014). The resulting certificates are also highly variable, with some training not resulting in any certificate. Some of these training courses are targeted to jobseekers seeking employment abroad. Links with private sector employers are present in some cases, but are not yet institutionalized. Apprenticeships seem to be infrequent.

Industry and sector training organizations are present in Myanmar. These include training sessions run by the Union of Myanmar Federation of Chambers of Commerce and Industry (UMFCCI), the Myanmar Garment Manufacturers' Association (MGMA), and the Myanmar Tourism Federation (MTF) (Milio, Garnizova, and Shkreli 2014). There are examples of these industry organizations at the local level, as well. For example, the Tanintharyi Chamber of Commerce launched the Human Resources Development Institute (HRDI) in Dawei, Tanintharyi Region, in early 2018 to develop the skills required in the local labor market. HRDI covers four townships, including Dawei. To date, HRDI has delivered two courses on cooking (for the hospitality industry) and computers. The average class size is about 20 participants. Courses include theoretical and practical training. HRDI was planning to expand to include courses in the Thai language, electrical work, and 
rubber tapping. All courses are short term with a variable duration (for example, rubber tapping is a one-week course (with practical demonstrations on a rubber plantation), while cooking classes are for one month. Participants are selected on a first-come, first-serve basis. HRDI charges no fees, but participants must buy their own ingredients for the cooking class. The Chamber of Commerce covers instructor fees and provides space for training. The fees are financed by voluntary contributions from members. Some members provide in-kind support such as equipment (like building materials, air conditioners, training equipment). Some local hotel owners are also associated with the training.

CSOs, NGOs, and international development organizations undertake many skills-training programs. These programs tend to focus on a particular geographic area of Myanmar and help link trainees with jobs once they complete the program.

- Equipping Youth for Employment. The Asian Development Bank (ADB)'s Equipping Youth for Employment (EYE) project includes support for diversifying and expanding competency-based modular short courses in areas including construction, welding, and agricultural machinery repair. This follows the ADB's Skills Development for Inclusive Growth project, which piloted these courses to help disadvantaged youth and unskilled workers with the hard skills that are in demand. Need-based stipends and dormitories are provided under the EYE project. EYE is to be implemented by the Ministry of Education and the Ministry of Industry between June 2017 and December 2022.

- Aung Myin Hmu. The Aung Myin Hmu project implemented by CARE Myanmar, the Sone Sie (formerly Pyoe Pin) program of the British Council, and
BusinessKind, seeks to improve the livelihoods of internal migrant women working in garment factories. Through a collaboration between the private sector and MOLIP, the project has developed a training model that aligns with the needs of the garment industry. Aung Myin Hmu signed an MOU with the Department of Labor running from 2017 to June 2021. The Department of Labor provides the venue for trainings provided by Aung Myin Hmu at the skills training center in North Dagon. The aim is to provide new migrants to Yangon's two largest industrial zones with skills that are in demand. Aung Myin Hmu also supports migrants by providing funds for crisis and legal services, and through the development of factory workers associations; it also provides the GOOD chatbot information and job-matching service, as well as information about services that are available to internal migrants pre- and post-departure.

- Linking Labutta to Markets. The Linking Labutta to Markets project, which is run by Mercy Corps and SwissContact, provides training in mechanics (9 weeks), garments (1 week in Labutta for life skills training and 3 weeks in Yangon), carpentry and masonry (8 weeks), and hospitality (7 weeks in Mandalay, Bagan, Nay Pyi Taw, and Yangon) to individuals in rural areas surrounding Labutta in the Ayeyarwady Region. The trainings include life skills training in migration, nutrition, communications, and personal development; classroom training; and practical training. A stipend of MMK20,000 per week (based on an income of about MMK3,000 per day), accommodations, and food are provided to participants. Linking Labutta to Markets also provides job-matching services to trainees. Between 2015 and the end of 2017, 812 participants were trained (500 were trained in 2017), 
and 300 graduates were placed, about 80 percent of them in Yangon and 20 percent in Pathein and elsewhere. The remaining graduates are self-employed and/or opened their own workshops. No participants have gone abroad for work.

- Skills for Employment. Helvetas's Skills for Employment project replaced a livelihoods-focused program ${ }^{11}$ that ran between 2014 and 2017. The trainings will be in automobile repair, garments, beauty, and other areas. The program will involve a dual education component and use results-based financing. The program will cover 10 townships in the Magway Region and target 2,000 participants, including disadvantaged people such as girls and young people who have dropped out of school. Trainers will include people from outside of Magway Region. Helvetas will conduct labor market assessments and create an employment plan for trainees. The new program has a regional approach, and Helvetas is engaging employers in Magway, but also employers in Yangon and other markets, in part because of the difficulty in attracting employers in Magway to job fairs.

- Growing Livelihoods in Bogale. The Christian development organization World Vision International Myanmar's (WVM) Growing Livelihoods in Bogale program provides skills training and helps people find jobs in the Ayeyarwady Region. At the beginning of the project, the organization facilitated workshops in villages to inform people about the types of skills training that would be offered. Participants were supported by WVM throughout the application process, including with obtaining their National Registration Card (NRC), searching for training schools, and selecting their desired courses. The program then asked 200 people what type of skills training they were interested in, helped match their interests with specific training courses, and connected them to the nonprofit Centre for Vocational Training (CVT). Currently, WVM provides training to around 200 people in skills such as auto and motorbike repair, pharmacy work, sewing, and baking. The project's intended goal is to support 250 people, so an extension is planned in the Ayeyarwady Region, as well as an expanded search for participants in additional villages.

- Vocational Skills Development Program. The Vocational Skills Development Project (VSDP) is funded by the Swiss Agency for Development and Cooperation (SDC) and implemented by a consortium led by SwissContact and includes the German company INBAS (Institute for Vocational Training, Labor Market, and Social Policy). Two of the VSDP's three components involve training programs. The Local Vocational Training (LVT) program is targeted to individuals from households earning less than MMK50,000 per month, individuals from households with only one member earning money, and migrant workers. The implementation partner is IOM, which oversees day-today management, including increasing awareness of the program, participant selection, and trainer contracts. The LVT project began in 2014, and its second phase began in 2018. The project operates 14 centers in 10 townships in Mon State and Kayin State. LVT provides market- and employmentoriented basic-level training courses in masonry, plumbing, sales, sewing,

11 The Skills for Rural Livelihoods Development (S4RLD) project focused on advancing the skills of the local communities in Magway Region. The intervention includes on- and off-farm skills development training activities for young men and women, and labor market assessments to inform training activities. 
rural mechanics, household electrical work, and beauty. The technical training is supplemented by training in life skills, such as communication, resume development, and job interview skills, as well as health, education, and safe migration.

Some courses are implemented in the government technical institute and the government technical high schools in Mawlamyine and Hpa-An. LVT trains occupational practitioners as instructors. There seems to be a high demand for training in rural mechanics among men, and sewing among women, and less interest in courses like plumbing. Courses are selected based on a market assessment of labor demand, and training centers can suggest changes based on their local context. The courses run for 3 months. A total of 3,995 participants were trained in the first phase (2014-18). The program is free of charge, and provides around MMK3,000 as a daily allowance. The exact allowance depends on the participant's location. Participants are evaluated based on attendance, mid-term assessment, and the final, practical test. Certificates are provided for attending the course and for successful graduation, depending on the evaluation. The program then offers the participants a link to employers and support for those wanting to start their own businesses. Of the 20 participants in a recent training course in Mawlamyine, 6 or 7 are now working in Yangon, some went to Thailand, and some work in Mon State. Some of the participants have set up their own businesses.

Another VSDP component is the Hotel and Tourism Industry (HTI) program, which provides training for hotel staff. $\mathrm{HTI}$ provides training to highly qualified hospitality professionals who then manage hospitality courses in hotels in Bagan, Mandalay, Nay Pyi Taw, and Yangon. These individuals train up to six supervisors who themselves then train small groups of hotel staff and people from disadvantaged backgrounds (Learners) in bell service and to be wait staff and room attendants. All courses are free, and Learners receive a daily allowance and a tailormade uniform. Graduates of the program who continue to work in the same occupation for more than 6 months have access to skills assessment by NSSA-accredited assessment centers. The program offers links to potential employers in the hospitality sector. A total of 2,335 graduates found employment between the program's inception in September 2014 and 2016; and more than half of the Learners trained between 2015 and 2016 found employment in the hospitality industry. The Ministry of Hotels and Tourism and the Myanmar Tourism Federation provide advice and support to the program. The program also works with the hospitality industry on its financial self-sustainability.

- Centre for Vocational Training. The Centre for Vocational Training (CVT) is a Yangon-based nonprofit organization that uses the Swiss and German dual education approach to apprenticeships. CVT first began offering classes in cabinetmaking in 2002, and they now offer several types of training.

- First, their Vocational Education and Training (VET) program offers dual vocational training that combines theoretical and practical coursework with apprenticeships. The 3-year VET program is offered for cabinetmakers, electricians, commercial assistants, metal workers, and hotel and gastronomy assistants. CVT cooperates with businesses to understand labor market needs and to adapt suitable 
curricula from Switzerland to Myanmar for the VET program. The curriculum is updated each year with the help of Swiss experts and local instructors and partner companies. Interested applicants must take an exam. In order to attend CVT vocational trainings, an individual generally must have a job; the employer typically pays for the training. CVT helps with job placement when necessary by working with its partner companies.

- $\quad$ Second, CVT's Education for Youth (E4Y) program introduces school leavers from disadvantaged backgrounds to vocational education. The 4-year E4Y program provides literacy and communication skills, vocational skills, and social skills, along with other support such as health checks. The program is free, and a daily meal plus a daily transportation allowance are provided. The E4Y program is generally oversubscribed; about 25 individuals are accepted in each class out of more than 200 applicants.

- Third, CVT's post-graduate programs instruct in-company trainers in the dual education-training model; they train professionals to provide skills training in their field and provide small business management training to young entrepreneurs (the Young Entrepreneurs for Myanmar (YE4M) program).

- Fourth, short courses are provided with private-sector partners like Myan Shwe Pyi Caterpillar, Myanmar Jardine Schindler Limited, Shwe Taung Development Company, and Maybank.

- Overall, CVT has 48 teachers, instructors, and staff in its vocational training program, and 13 E4Y teachers and staff. Twenty-four vocational training classes are offered, along with 4 E4Y classes. Over one thousand people have graduated from the apprenticeship program since 2002. In order to enhance the capacity and programs of CVT, CVT signed an MOU with the Department of Labor running from 2013 to 2023. According to the MOU, CVT applies for vacant land of 1.2 acres owned by the Department of Labor for the construction of a training center, practical rooms, and a warehouse for further expansion. During and after the project, the Department of Labor will own the land and the building. CVT has a local advisory board that consists of members from enterprises (such as hotel and gastronomy, tourism), government (MOE and MOLIP), and the education sector. The board helped introduce the short course program. Some Instructors from CVT are NSSAaccredited assessors and conduct skills assessments at NSSA-accredited assessment centers as volunteers. Government ministries (MOLIP, MOE) and the Swiss Agency for Development and Cooperation (SDC) have provided support for a new CVT building.

- Twe Let. The International Organization for Migration's (IOM's) Twe Let project supports skills-development training for people migrating within Myanmar and abroad, as well as the families of those migrants. The program is being implemented in Chin State, Kayin State, Magway Region, Mandalay Region, Mon Region, Shan State, and Tanintharyi Region. In the Dry Zone, the government technical college and the government technical high school are involved in the training, along with a private beauty salon and a motorbike repair shop. The curriculum was developed by local partners and the IOM.

\section{Areas for improvement and potential gaps}

Myanmar has sought to increase its skillstraining infrastructure in recent years, but the public training sector faces significant challenges. Many different ministries in Myanmar provide training, including both 
formal TVET and informal short-term courses. However, public provision of skills training faces significant challenges. Training courses tend to be offered in a limited range of subjects, with curricula that are not standardized and that do not reflect the needs of industry, especially for high technology. Planning and financing are not coordinated, and duplicate courses are often offered. Skills training programs run by NGOs that seem to have had success in Myanmar have combined the training program with a job-matching componentin particular, a job-matching component that connects individuals in rural areas with employers in urban areas like Yangon. Building strong connections with employers, including those in major areas of economic development, would help skills-training programs succeed. In some cases, resource constraints also play a role; for example, the Department of Labor's six training centers seem to lack equipment, resources, and qualified trainers. The training center in Pathein, for instance, has no full-time training staff. The center has trained only 103 people since 2011. Without human and financial resources, it has been difficult to attract people to take the training. International Spotlight 1 in Chapter 4 provides an example of a program in China that helped expand access to training opportunities.

\section{Labor market information}

Labor market information is any information that is useful for jobseekers, employers, educational institutions, training providers, and other labor market stakeholders that make decisions. This includes information about labor demand, labor supply, labor market intermediaries, labor market policy, and employment conditions. Table 2.1 provides examples of the types of information that can be provided in these different areas.

Table 2.1

\section{Types of labor market information}

\begin{tabular}{|c|c|}
\hline Area & Types of information \\
\hline Labor demand & $\begin{array}{l}\text { - Employers and their industries } \\
\text { - Vacancies } \\
\text { - In-demand occupations and skills } \\
\text { - Wages }\end{array}$ \\
\hline Labor supply & $\begin{array}{l}\text { - Employed population and their characteristics and skills } \\
\text { - Jobseekers and their skills }\end{array}$ \\
\hline $\begin{array}{l}\text { Labor market } \\
\text { intermediaries }\end{array}$ & $\begin{array}{l}\text { - Schools, training institutions, and their graduates } \\
\text { - Recruitment agencies } \\
\text { - Public employment services }\end{array}$ \\
\hline Labor market policy & $\begin{array}{l}\text { - Minimum wage } \\
\text { - Employment protection legislation } \\
\text { - Active labor market policies }\end{array}$ \\
\hline Employment conditions & $\begin{array}{l}\text { - Benefits } \\
\text { - Working hours } \\
\text { - Working environment }\end{array}$ \\
\hline
\end{tabular}


The sources of labor market information are numerous and diverse. Labor market information is available from government sources such as surveys and censuses. Labor market information is also available from public administrative records and from private sources, such as recruitment agencies and online job portals. Qualitative labor market information can also be collected, including from consultations and interviews with employers, industry associations, and recruitment agencies.

Labor market information is available from several different sources in Myanmar (Table 2.2): from censuses, which collect data on the entire population; from surveys, which are representative of a certain portion of the population; and from administrative data, which are collected in the process of

\section{Table 2.2}

\section{The sources of labor market information in Myanmar}

\begin{tabular}{|c|c|c|c|c|}
\hline & Name & Source/Scope & Frequency & Coverage \\
\hline \multirow{2}{*}{ 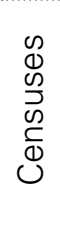 } & Population Census & $\begin{array}{l}\text { Ministry of Home and Religious } \\
\text { Affairs }\end{array}$ & 1983 & Census \\
\hline & $\begin{array}{l}\text { Myanmar Population and } \\
\text { Housing Census }\end{array}$ & $\begin{array}{l}\text { Ministry of Labor, Immigration, and } \\
\text { Population (MOLIP) }\end{array}$ & 2014 & Census \\
\hline \multirow{7}{*}{ 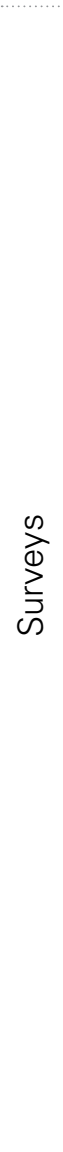 } & Labor Force Survey & $\begin{array}{l}\text { Ministry of Labor (with ILO, UNFPA, } \\
\text { UNDP) }\end{array}$ & 1990 & - \\
\hline & $\begin{array}{l}\text { Myanmar Labor Force, Child } \\
\text { Labor, and School-to-Work } \\
\text { Transition Survey }\end{array}$ & $\begin{array}{l}\text { Ministry of Labor, Employment, and } \\
\text { Social Security; Central Statistical } \\
\text { Organization (CSO) (with ILO) }\end{array}$ & 2015 & $\begin{array}{l}\text { National; } \\
\text { urban/rural; } \\
\text { state/region }\end{array}$ \\
\hline & Labor Force Survey & MOLIP (with ILO) & $\begin{array}{l}\text { Biannually } \\
\text { from } 2017 \text { with } \\
\text { annual report }\end{array}$ & $\begin{array}{l}\text { National; } \\
\text { urban/rural; } \\
\text { state/region }\end{array}$ \\
\hline & $\begin{array}{l}\text { Integrated Household Living } \\
\text { Conditions Assessment }\end{array}$ & $\begin{array}{l}\text { Ministry of National Planning and } \\
\text { Economic Development; CSO (with } \\
\text { UNDP, International IDEA) }\end{array}$ & 2005 and 2010 & $\begin{array}{l}\text { National; } \\
\text { urban/rural; } \\
\text { state/region }\end{array}$ \\
\hline & $\begin{array}{l}\text { Household Income and } \\
\text { Expenditure Survey }\end{array}$ & $\mathrm{CSO}$ & $\begin{array}{l}5 \text { times, every } \\
6 \text { years, } 1989 \\
\text { to } 2012\end{array}$ & - \\
\hline & $\begin{array}{l}\text { Myanmar Poverty and Living } \\
\text { Conditions Survey }\end{array}$ & $\begin{array}{l}\text { Ministry of Planning and Finance; } \\
\text { CSO (with World Bank, Korea Trust } \\
\text { Fund for Peace-building Transitions) }\end{array}$ & 2015 & $\begin{array}{l}\text { National; } \\
\text { urban/rural; } \\
\text { Agricultural } \\
\text { zone }\end{array}$ \\
\hline & $\begin{array}{l}\text { Myanmar Living Conditions } \\
\text { Survey }\end{array}$ & CSO (with World Bank, UNDP) & 2017 & $\begin{array}{l}\text { National; } \\
\text { urban/rural; } \\
\text { state/region }\end{array}$ \\
\hline \multirow{2}{*}{$\frac{. \frac{5}{\varepsilon}}{\frac{\varepsilon}{q}}$} & $\begin{array}{l}\text { Jobseeker, vacancy, and } \\
\text { placement registration }\end{array}$ & LEOs, recruitment agencies & Real time & $\begin{array}{l}\text { National (not } \\
\text { representative) }\end{array}$ \\
\hline & $\begin{array}{l}\text { Licensed recruitment } \\
\text { agencies }\end{array}$ & Department of Labor & Periodic & $\begin{array}{l}\text { National } \\
\text { (representative) }\end{array}$ \\
\hline
\end{tabular}


delivering services (and may have more or less detail than survey data but may permit analysis of the labor market at smaller geographies since representativeness is not a concern). Two censuses have been conducted in Myanmar in the last 4 decades, one in 1983 and the latest in 2014. Survey data are collected, including through a biannual labor force survey. Administrative data on the labor market are available via jobseeker, vacancy, and placement registrations at LEOs and from private recruitment agencies.

The Labor Force Survey (LFS), which is collected quarterly by the Ministry of Labor, Immigration, and Population, with the support of the ILO, has the explicit objective of gathering information about the health of the labor market, which makes it a valuable tool to analyze labor market trends. The LFS is conducted regularly and is representative at the national and subnational levels. Although several other representative household surveys have collected information about labor market characteristics, they are not conducted regularly, which limits the ability to analyze trends in the labor market over time.

Labor market information is also available from administrative data in Myanmar. The backbone of labor market information is registrations of jobseekers, employers, and job vacancies by LEOs. Jobseekers are required to register at LEOs, as are employers who report job vacancies and job hirings. The LEOs track these registrations in manual ledger books and in the Labor Exchange Office Management System-an information management system (database)of registered jobseekers and job vacancies-within the Employment Division. ${ }^{12}$ Reports are produced by LEOs for the state and region offices of the
Department of Labor, and by the state and region offices for the Union-level Department of Labor once every 2 weeks (they are consolidated from ledger books and typed into an Excel workbook) and again once every month following the same process. ${ }^{13}$ These reports are consolidated for MOLIP, and published on its website. When there are inconsistencies between paper (or e-mail) reports and the Labor Exchange Office Management System database, the state and region offices check both paper and e-mail reports and the database and, if necessary, revise the database. Inconsistencies may arise because of a lack of internet connectivity at the LEOs. LEO Forms 10 through 15 are used for this reporting, although not all forms are used in practice. Table 2.3 describes the information provided in these reports.

Labor market information is also reported by private recruitment agencies. Private recruitment agencies are required to report to the Department of Labor the number of jobseekers they have placed in jobs each month. The extent to which agencies comply with this requirement is not known.

Labor market information is disseminated through several channels. MOLIP, the Central Statistical Organization, and partners involved in undertaking surveys publish their reports based on the labor market data derived from surveys. These publications are generally targeted to policy makers and policy experts. However, labor market information is also used to improve service delivery. LEOs and state and region Department of Labor offices can view the list of jobseekers and vacancies throughout Myanmar using the Labor Exchange Office Management System. This system enables staff to direct jobseekers to areas where

12 The Union-level Employment Division office, the 83 Labor Exchange Offices, and the 15 state and region Department of Labor offices currently have access to this system. The Employment Division is seeking to expand access to the Department of Labor officers in the special economic zones.

13 Rakhine State reportedly sends these reports on a weekly basis. 
Table 2.3

Reports on jobseekers, vacancies, and job placements

\begin{tabular}{|c|c|c|}
\hline Number & Title & Examples of information reported \\
\hline Form 10 & $\begin{array}{c}\text { Monthly Record of } \\
\text { Registered Jobseekers }\end{array}$ & $\begin{array}{l}\text { - New jobseekers registered by gender and skill } \\
\text { - Jobseekers placed by LEO by gender and skill } \\
\text { - Jobseekers finding a job on their own by gender and skill } \\
\text { - Jobseekers removed from jobseeker registration by gender and } \\
\text { - skill } \\
\text { - Total number of registered jobseekers by gender and skill }\end{array}$ \\
\hline Form 11 & & Not used \\
\hline Form 12 & & Not used \\
\hline Form 13 & & Not used \\
\hline Form 14 & $\begin{array}{c}\text { Monthly Record of } \\
\text { the Education Level } \\
\text { of Newly Registered } \\
\text { Jobseekers }\end{array}$ & - Number of newly registered jobseekers by education and gender \\
\hline Form 15 & $\begin{array}{c}\text { Monthly Record of the } \\
\text { Age of Newly Registered } \\
\text { Jobseekers }\end{array}$ & - Number of newly registered jobseekers by age and gender \\
\hline
\end{tabular}

Source: Authors.

there are more job openings. Labor market information is also used to inform labor market stakeholders directly (Table 2.4).

Labor market information is also available from private online job-search services, although these services are primarily designed to match jobseekers with jobs. For-profit, online job-search portals provide a venue for employers to post job vacancies and for jobseekers to search and apply for jobs. These services generally allow jobseekers to search job vacancies for free and may allow employers to search for potential candidates. This is valuable for both parties-each can evaluate the types of skills, experience, and other qualifications demanded by employers and being supplied by jobseekers. Firms such as MyJobs, JobNet, and Jobs in Yangon offer these services, which are primarily designed for more-skilled workers. Job postings on online job portals also represent a potential source of labor market information when they are aggregated.
These vacancies can be collected by a web "scraper" or "spider" that automatically collects information from web pages. The vacancies can then be categorized and analyzed for insights into the labor market. Although these vacancies are likely skewed toward more highly skilled employment, they do provide a real-time indication of vacancies as well as detailed data on the skills required by employers and the qualifications of jobseekers. Box 2.1 provides an example of an initiative that uses online job-search websites as a source of labor market information in Myanmar. Still, the primary objective of online job portals in Myanmar is to match jobseekers and employers.

The Telenor Communications Company, in partnership with Myanmar ICT for Development Organization (MIDO) runs a corporate social responsibility (CSR) program called Lighthouse that helps people utilize the internet in an effective way-which is particularly helpful for those 
Table 2.4

\section{Tools for providing labor market information directly to jobseekers}

\begin{tabular}{|c|c|}
\hline Number & Examples of information reported \\
\hline LEO notice boards & LEOs post registered vacancies on physical job boards at their offices. \\
\hline $\begin{array}{l}\text { Myanmar Job } \\
\text { website }\end{array}$ & $\begin{array}{l}\text { Jobseekers and employers are able to search for job openings and candidates, } \\
\text { respectively, on a publicly available website. This is the public "front end" of } \\
\text { the Labor Exchange Office Management System.a LEOs have been conducting } \\
\text { awareness-raising programs about this website since September } 2017 .\end{array}$ \\
\hline Mobile teams & $\begin{array}{l}\text { Mobile teams were created in } 2012 \text { to raise awareness about employment laws and } \\
\text { to help jobseekers register with LEOs and connect with employers without needing } \\
\text { to travel to LEOs in person. The mobile teams sometimes visit villages to advertise } \\
\text { job openings. }\end{array}$ \\
\hline Job fairs & $\begin{array}{l}\text { The state and region Department of Labor offices host job fairs to increase awareness } \\
\text { about job openings and about labor laws and regulations. For instance, job fairs were } \\
\text { held in } 2017 \text { and early } 2018 \text { in Magway and Pakokku to allow licensed overseas } \\
\text { employment agencies to explain the services they provide, the migration process, } \\
\text { and the cost. Fifteen agencies attended the fairs. Because there was a concern that } \\
\text { villagers did not understand the concept of a job fair, job-matching services were not } \\
\text { provided. }\end{array}$ \\
\hline Awareness raising & $\begin{array}{l}\text { State and region Department of Labor offices and the LEOs undertake awareness } \\
\text { programs with the General Administration Department (GAD) and other departments } \\
\text { on labor law and migration. For instance, in 2017, the Magway Region Department } \\
\text { of Labor held } 38 \text { awareness-raising events at the township level, and coordinated } \\
\text { with GAD and village heads about laws related to internal and international migration. } \\
\text { These events use a PowerPoint presentation, but do not provide handouts. }\end{array}$ \\
\hline
\end{tabular}

a See http://www.myanmarjob.gov.mm/ (last accessed January 17, 2019).

Source: Authors.

\section{Box 2.1 Using real-time labor market information in Myanmar}

Online job search websites in Myanmar can be a source of insight into labor market dynamics. The Singaporean labor market analytics firm, JobKred, recently undertook an analysis of the online job search website JobNet.com.mm in partnership with UNESCO. The analysis collected job titles from the job portal to understand which ones appeared most frequently as an indicator of demand. The analysis also collected information about skills from job descriptions included on the website. The top skills in different occupations, such as sales, marketing, and management for sales managers and teamwork, software, and applications for IT hardware and software jobs were identified through this analysis.

Source: UNESCO 2019. 
searching for jobs on different job portals. The program offers free $\mathrm{Wi}-\mathrm{Fi}$ and three computers for a duration of 18 months at digital literacy training centers. A focal person is responsible for raising awareness about using the internet and for sharing job-search websites. Telenor plans to focus on rural areas, especially where there are Telenor servers, to reduce the digital divide between urban and rural areas. The program provides a potential platform for information dissemination and e-learning support for aspirant and return migrants, as well as for migrant-sending families.

Several CSOs, NGOs, and international development organizations have developed innovative approaches to deliver labor market information to less-skilled workers and jobseekers via technology. For instance, SMART Myanmar, a European Union-funded project that supports sustainable consumption and production of Myanmar-made garments, has developed two Android apps to provide information to garment sector workers. Shwe Job uses interactive stories and voiceovers to educate about labor laws and occupational safety and health in garment factories. And Satyone Superstar uses a game to instruct users about labor laws and occupational safety and health.

The GOOD chatbot, developed in the Aung Myin Hmu project, is one of the most advanced examples of a nonprofit initiative to deliver labor market information to lessskilled workers and jobseekers. The Aung Myin Hmu project] is implemented by the NGO CARE Myanmar, the Sone Sie (formerly Pyoe Pin) program run by the British Council in Burma, and BusinessKind, a nonprofit organization that establishes social businesses in poor communities in Myanmar. The project seeks to improve the livelihoods of internal migrant women in the garment sector. The project has partnered with MyJobs, one of the leading online job search websites in Myanmar, to create an employment information and job search chatbot for low-skilled garment sector workers in order to reduce reliance on labor brokers and reduce employment gaps. The GOOD chatbot provides information about job searches and recommends a small number of job openings via Facebook Messenger. The marketing of the tool is done through Facebook, which is relatively cheap and has a wide reach for advertisements, as well as through WhatsApp and Viber. The chatbot obtains basic information about the jobseeker (for example, name, hometown, age, gender) and asks them whether they are expecting a salary of more than MMK300,000. Because the tool is designed for less-skilled workers, those people expecting a higher salary are directed to the MyJobs website. If not, they are shown a limited number of jobs, are asked whether they are interested in them, and are provided information about the Aung Myin Hmu training center for garment sector workers. MyJobs vets the jobs by visiting with employers and asking them about wages, overtime pay, paid leave, employment contracts, working hours, and their awareness of labor regulations. The MyJobs team works with about 10 employers. Most of the jobs offered are in Yangon, while most of the jobseekers are from outside of Yangon. Tens of vacancies are available to jobseekers via the GOOD chatbot. The chatbot has more than 70,000 users.

The GOOD chatbot has focused primarily on providing information rather than providing job matching or placement services. This is because identifying vacancies for low-skilled workers is challenging for the service, and low-skilled workers tend to identify jobs via their own networks. Identifying vacancies is challenging, in part, because the project does not have direct access to employers and, in part, because of the need to verify the vacancies that are posted. The GOOD 
chatbot has allowed MyJobs to create a database of jobseekers to whom targeted messages can be sent and a platform for two-way communication. This is possible with Facebook Messenger even if users change the SIM card on their mobile phone, because people generally maintain a single Facebook username. MyJobs is hoping to be able to develop the GOOD chatbot into a commercial product in the future, in part by leveraging the database of workers created by the chatbot.

The GOOD chatbot project has invested in understanding how less-skilled workers use the internet in Myanmar. The project has found that many less-skilled people in Myanmar do not use internet services beyond Facebook, because they are conscious of data charges and avoid using functions that require data, and most of these individuals experience the internet via their mobile devices rather than laptops. As a result, the chatbot uses simple, textbased questions ${ }^{14}$ to limit the amount of data that users consume.

Offline forums have also been created to provide information to less-skilled workers. The Sunday Café is hosted by Thone Pann Hla, an association of female garment factory workers (many of them internal migrants) initiated by BusinessKind. The Sunday Café is an educational and social platform, where legal advice, educational materials, and training are provided, and socializing can occur. SMART Myanmar opened a second Sunday Café and reports that between 40 and 200 female workers attend the two Sunday Cafés. ${ }^{15}$ The Sunday Cafés also run hostels for internal migrants, in part to generate income. The Confederation of Trade Unions Myanmar (CTUM) has opened a separate Women
Workers' Centre in Hlaing Thar Yar township, with support from the German development agency GIZ, which will provide legal counselling, skills training, and knowledge sharing. CTUM has plans to open additional centers.

Several NGOs have incorporated labor market information into their existing programs. Several provide information on safe migration to internal migrants, most of whom are migrating for work. In Labutta in Ayeyarwady Region, the Linking Labutta to Markets program, which is run by the NGO Mercy Corps and the private foundation SwissContact, includes a subcomponent about migration in the life-skills-training component of its training program. The IOM has twice provided training to trainers from Linking Labutta to Markets about legal and illegal migration and antitrafficking. The IOM X campaign and its Miss Migration Facebook page provide information to internal and international migrants, including through a chatbot, to help prevent trafficking and exploitation. Other projects incorporate labor market assessments into their programming. IOM's Twe Let project, which seeks to improve the development impact of internal and international migration, is planning to use labor market assessments to improve the relevance of its training programs, as is the Swiss development organization Helvetas's Skills for Employment project. In addition to the GOOD chatbot, the Aung Myin Hmu project provides information about services available to internal migrants prior to their departure.

\section{Areas for improvement and potential gaps}

While several sources of labor market

14 While the GOOD chatbot does not currently have any pictures, pictures may be added in the future as users seem to be becoming less
sensitive to price.

15 See https://www.smartmyanmar.org/en/sunday-cafes (last accessed January 23, 2018). 
information exist in Myanmar, the collection of job vacancy data by LEOs is limited. The mandatory requirement for employers to register job vacancies with LEOs would require additional engagement with employers to be effective. The Employment Restriction Act (1959) and its subsequent regulations require employers to register job vacancies with LEOs. This is currently one of the only sources of vacancy information available to the Department of Labor. However, compliance with this requirement is weak, meaning that the vacancies collected by LEOs are not an accurate representation of labor demand. Indeed, registration of public sector employment opportunities seems to be more frequent than registration of private sector opportunities. While information campaigns about employers' responsibilities have helped raise awareness, the requirement is seldom enforced. International experience shows that mandates to register job vacancies are often ineffective because of the challenge of implementation and the significant cost of enforcement. Almost no developed economies require registration of job vacancies. Instead of requiring employers to register job vacancies, the Department of Labor through its LEOs could develop partnerships with employers, private recruitment agencies, and online job portals to develop a voluntary mechanism for reporting them; this would provide a more holistic picture of labor demand.

A lack of access to survey data also limits the availability of labor market information. Several surveys relevant to the labor market have been undertaken in Myanmar recently. The commitment to issue the Labor Force Survey on a regular basis is particularly important for providing up-to-date information on labor market dynamics. However, information from the
Labor Force Survey has not yet been made widely available. Doing so would enhance the ability of experts to understand labor market dynamics, and it could also provide jobseekers themselves with a better understanding of the jobs and skills that are in demand-that is, if the survey data were processed and disseminated with jobseekers in mind.

Research from around the world shows the importance of providing information about the labor market to students and jobseekers that are making decisions about education, training, and jobs (see International Spotlight 7in Chapter 4). Overall, information about the labor market is not widely available. As noted above, LEOs rely exclusively on the registration of jobseekers and of job vacancies as their labor market information. These registrations do not capture the entire universe of jobseekers or job vacancies, which limits the usefulness of this information both for providing job-matching and -placement services and for analyzing labor market dynamics. Additionally, LEOs do not advertise the jobs that are available in other locations, such as jobs in Yangon, Mandalay, other urban areas, or even abroad. LEOs also do not encourage internal recruitment agencies or overseas employment agencies to post vacancies at LEOs. Finally, labor market information is publicized primarily through physical job boards posted at LEO offices, where they are only seen by those visiting the offices; jobs are also posted on the job search website of the Department of Labor, ${ }^{16}$ which at times suffers from poor functionality. Awareness and use of the website appears to be limited. Additionally, officers at LEOs are generally restricted to entering jobseeker and job vacancy registration information onto forms and into a database only, and they typically do not 
seek out employers who are hiring, project employment and skills needs, inform training programs, or identify overseas employment opportunities. In fact, there seems to be a limited interaction between LEOs and employers. As a consequence, jobseekers tend to rely on informal channels to gather information about the labor market. For instance, aspiring internal migrants from Ayeyarwady, Magway, Mandalay, Rakhine, and Shan, especially young women, tend to use their social networks to collect information on jobs and accommodations (Pattison et al. 2016b; Deshingkar, Litchfield, and Ting 2019).

Weaknesses in the management of labor market information create inefficiencies in its collection and use. The collection of labor market information related to jobseekers and employers is done manually by LEO staff on a series of forms; the same information is then reentered into the Labor Exchange Office Management System. Jobseekers and employers must show up in person to register with LEOs. For example, jobseekers cannot register online, and employers must register in person the first time they list a job vacancy. Anecdotal evidence suggests that state and region Directors of Labor continue to rely on both paper and e-mail reports from LEOs, and they double-check the information in the Labor Exchange Office Management System before sending final reports to Nay Pyi Taw. This undermines some of the time savings created by the digital management system. There is also evidence that LEOs have had trouble accessing the internet when they try to upload jobseeker and vacancy registrations to the central Labor Exchange Office Management System. ${ }^{17}$

The familiarity of both jobseekers and employers with digital tools for job searching may need to be enhanced. Lower-skilled workers, in particular, may not be familiar with using online job search sites or tools like e-mail to connect with employers. Employers may be unfamiliar with the digital tools to search for jobseekers or the best way to describe jobs to solicit qualified candidates.

\section{Job matching and placement}

Job matching and placement services actively match jobseekers to jobs. Such services evaluate jobseekers' qualifications against the qualifications required by job vacancies and then inform the jobseeker or the employer of the match, or they take an active role in making the match between jobseeker and employer. Public employment services and nonprofit providers in Myanmar tend to focus on low-skilled jobseekers, while most private providers tend to target mid- and highskilled workers.
LEOs are the primary public providers of jobmatching and -placement assistance. They use a three-step process: they (1) register jobseekers, (2) register job vacancies, and then (3) connect registered jobseekers to registered job vacancies through a manual matching process. Online Appendix 3 describes this process in detail.

- Registering jobseekers. People looking for work must register as jobseekers at a LEO. ${ }^{18}$ To obtain a jobseeker registration card, the person must be 18 years old,

\footnotetext{
17 For instance, lack of internet access in the Pathein LEO means that the LEO staff must plug in a Wi-Fi "hot spot" in order to upload registration information to the online Labor Exchange Office Management System.

18 A jobseeker is permitted to register once a year at another LEO in their area. If they have moved to another area, they can exchange their registration card at the LEO in their new location.
} 
show the original and a copy of their educational qualifications, and present their original national registration card (NRC). LEOs register jobseekers via registration cards (Form 2), which are valid for a year. Separate cards are issued to individuals looking for jobs domestically and those looking for jobs internationally. Currently, jobseekers cannot register online and must visit a LEO in person to do so-although the Department of Labor is considering enabling jobseekers to register online. When they register, jobseekers are required to provide information about their education and employment history and the jobs they are interested in. LEO staff then transcribe this information (using Form 1), which helps them match job candidates with vacancies. The LEO staff categorize jobseekers according to the International Standard Classification of Occupations (ISCO).

- Registering job vacancies. The Employment Restriction Act (1959) and the Employment and Skills Development Law (2013) require private and public employers to register job vacancies with LEOs, although LEO staff sometimes gather this information informally from the employers themselves. ${ }^{19}$ Employers must visit a LEO in person to register as an employer (using Form 9), the first time they register a job vacancy (using Form 3), and after that point, the employer is issued a username and a password that permit online registration of subsequent job openings in the Labor Exchange Office Management System.

- Matching jobseekers and job vacancies. LEO staff pool jobseekers by age and occupation and seek to match registered jobseekers with registered job vacancies using the education and employment history provided by the jobseeker (on Form 1) and the job descriptions provided by employers (on Form 3). LEO staff contact potential jobseekers to ask if they are interested in the vacancy. This was formerly done via a paper form (Form 5) but is now done by telephone. LEO staff send a list of qualified applicants to the employer (using Form 6), who then decides which candidates to interview and contacts them directly. The employer provides the LEO with the list of candidates who have been hired (using Form 6 with a note from the employer), and the LEO in turn issues the hired jobseeker with an employment card (Form 7), indicating that they have been hired. LEO staff can also refer jobseekers to training centers and to predeparture training for those considering international migration.

State and region Department of Labor offices host job fairs to facilitate job matching. For instance, in 2018, the Mon State Department of Labor Office in Mawlamyine hosted a job fair financed by SwissContact. The job fair was attended by 7 overseas recruitment agencies and 16 employers, 3 or 4 of which were from Yangon, while the others were mostly local firms working in construction, hotel, and rubber. During the job fair, 601 vacancies were listed, 874 jobseekers applied for jobs, and 274 were hired. Three hundred seventy-six jobseeker registration cards were issued.

The private market for job matching and placement services in Myanmar can be

19 According to LEO procedures, before posting job advertisements to newspapers, employers are required to obtain approval from a state or region Department of Labor office. This does not appear to occur in practice. 
segmented into licensed recruitment agencies, informal recruitment agents and brokers, and online job-matching agencies. Table 2.5 provides an overview of several private-sector providers of job-matching and -placement services. The use of these private services is limited. Around 5 percent of jobseekers report registering with a jobsearch agency, and only 1 percent report replying to ads in newspapers or posters or on the internet (Cunningham and Muñoz 2018).

\section{Table 2.5}

\section{Overview of private job matching and placement agencies in Myanmar}

\begin{tabular}{|c|c|c|c|c|c|c|c|}
\hline $\begin{array}{l}\text { Company/ } \\
\text { Agency }\end{array}$ & Type & Foreign & $\begin{array}{c}\mathrm{Li}- \\
\text { censed }\end{array}$ & Website & Targeted workers & Size & Fees \\
\hline $\begin{array}{l}\text { Ngwe Yoe/ } \\
\text { Ngwe Moe }\end{array}$ & $\begin{array}{l}\text { Low-skilled } \\
\text { recruitment }\end{array}$ & $N$ & Y & $\mathrm{N}$ & Low-skilled & $\begin{array}{l}\text { Placed around } \\
2,000 \text { jobseekers } \\
\text { in jobs in } 2018\end{array}$ & $\begin{array}{l}\text { Jobseekers are } \\
\text { asked for a voluntary, } \\
\text { upfront contribution } \\
\text { Employers are } \\
\text { charged for matches, } \\
\text { at } 1 \text { month's } \\
\text { salary with a 90- } \\
\text { day employment } \\
\text { guarantee or another } \\
\text { worker is provided }\end{array}$ \\
\hline $\begin{array}{l}\text { Perfect Supply } \\
\text { Services/ } \\
\text { Perfect Supply } \\
\text { Services }\end{array}$ & $\begin{array}{l}\text { Mid- or } \\
\text { high-skilled } \\
\text { recruitment }\end{array}$ & $\mathrm{N}$ & Y & $\mathrm{N}$ & $\begin{array}{l}\text { Mid- and high- } \\
\text { skilled }\end{array}$ & Staff of 40 & $\begin{array}{l}\text { Employers are } \\
\text { charged for matches, } \\
\text { at } 52 \text { percent of } 1 \\
\text { month's salary }\end{array}$ \\
\hline $\begin{array}{l}\text { MyWorld/ } \\
\text { MyWorld } \\
\text { Careers }\end{array}$ & $\begin{array}{l}\text { Mid- or } \\
\text { high-skilled } \\
\text { recruitment }\end{array}$ & $\mathrm{N}$ & Y & Y & $\begin{array}{l}\text { Mid- and high- } \\
\text { skilled }\end{array}$ & - & - \\
\hline $\begin{array}{l}\text { MyJobs/JPE } \\
\text { Everest }\end{array}$ & $\begin{array}{l}\text { Mid- or } \\
\text { high-skilled } \\
\text { recruitment }\end{array}$ & $N$ & Y & $\mathrm{N}$ & $\begin{array}{l}\text { Mid- and high- } \\
\text { skilled (>= } \\
\text { MMK 500,000 } \\
\text { per month; } \\
\text { managers, } \\
\text { supervisors, and } \\
\text { above) }\end{array}$ & $\begin{array}{l}\text { Works with } 38 \\
\text { companies } \\
\text { Has placed around } \\
400 \text { people in jobs }\end{array}$ & $\begin{array}{l}\text { Employers are } \\
\text { charged for matches } \\
\text { and are guaranteed } 2 \\
\text { months employment }\end{array}$ \\
\hline MyJobs/N.A. & $\begin{array}{l}\text { Online job- } \\
\text { matching } \\
\text { agency }\end{array}$ & Y & N & Y & $\begin{array}{l}\text { Mid- and high- } \\
\text { skilled (at least } \\
\text { bachelor's } \\
\text { degree) }\end{array}$ & $\begin{array}{l}1.8 \text { million users } \\
400-500 \text { client } \\
\text { employers } \\
4,600-4,700 \\
\text { vacancies }\end{array}$ & $\begin{array}{l}\text { Employers are } \\
\text { charged a small } \\
\text { fee to advertise } \\
\text { vacancies }\end{array}$ \\
\hline JobNet/N.A. & $\begin{array}{l}\text { Online job- } \\
\text { matching } \\
\text { agency }\end{array}$ & Y & $N$ & Y & $\begin{array}{l}\text { Mid- and high- } \\
\text { skilled (profes- } \\
\quad \text { sionals) }\end{array}$ & 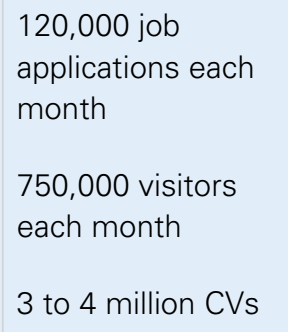 & $\begin{array}{l}\text { Employers are } \\
\text { charged a fee to } \\
\text { advertise vacancies }\end{array}$ \\
\hline
\end{tabular}




\begin{tabular}{|c|c|c|c|c|c|c|c|}
\hline $\begin{array}{l}\text { Company/ } \\
\text { Agency }\end{array}$ & Type & Foreign & $\begin{array}{l}\text { Li- } \\
\text { censed }\end{array}$ & Website & Targeted workers & Size & Fees \\
\hline $\begin{array}{l}\text { Roger Quest In- } \\
\text { ternational/N.A. }\end{array}$ & $\begin{array}{l}\text { Online job- } \\
\text { matching } \\
\text { agency }\end{array}$ & $\mathrm{N}$ & $\mathrm{N}$ & Y & $\begin{array}{l}\text { Mid- and high- } \\
\text { skilled (at least } \\
\text { graduates) }\end{array}$ & $\begin{array}{l}\text { 200,000 CVs } \\
500,000 \text { online } \\
\text { applications }\end{array}$ & $\begin{array}{l}\text { Employers are } \\
\text { charged a fee to } \\
\text { advertise vacancies }\end{array}$ \\
\hline $\begin{array}{l}\text { Work.com. } \\
\text { mm/N.A. }\end{array}$ & $\begin{array}{l}\text { Online } \\
\text { job- } \\
\text { matching } \\
\text { agency }\end{array}$ & Y & $\mathrm{N}$ & Y & - & Closed & - \\
\hline Neh Thit/N.A. & $\begin{array}{l}\text { Online job- } \\
\text { matching } \\
\text { agency }\end{array}$ & Y & $N$ & Y & $\begin{array}{c}\text { Has shifted } \\
\text { from low-skilled } \\
\text { to mid-skilled } \\
\text { (jobseekers with } \\
\text { some education) }\end{array}$ & - & $\begin{array}{l}\text { Employers are } \\
\text { charged a small } \\
\text { fee to advertise } \\
\text { vacancies }\end{array}$ \\
\hline $\begin{array}{l}\text { Dream Job } \\
\text { Myanmar/ } \\
\text { Dream Job } \\
\text { Myanmar }\end{array}$ & $\begin{array}{c}\text { Recruitment } \\
\text { for particular } \\
\text { companies }\end{array}$ & $N$ & $Y$ & $Y$ & - & - & - \\
\hline
\end{tabular}

N.A. indicates not applicable.

"_" indicates not available.

Source: Authors.

Licensed recruitment agencies identify jobseekers and job vacancies and match particular jobseekers to particular vacancies on behalf of employers. Licensed recruitment agencies can be broken down into three subcategories. First, a group of licensed recruitment agencies recruits for the mid- and high-skilled market and undertakes executive searches or headhunting (for example, Perfect Supply Service); those firms recruiting only for executives are said to be struggling. Second, a group of licensed recruitment agencies specializes in recruiting for particular companies (for example, Dream Job Myanmar). Third, a single firm, Ngwe Yoe, recruits low-skilled jobseekers.

In order to become a licensed recruitment agency, a registered company owned by a Myanmar national must apply for a license from the Department of Labor with supporting documents, including a clearance letter from the Special Police and a work recommendation letter. The newly formed agency must pay a deposit and pay monthly fees. The license must be renewed annually in person in Nay Pyi Taw. The agency must provide a monthly report on the number of people placed in jobs and must fill 500 vacancies each year to maintain its license, although this requirement does not seem to be enforced. The maximum recruitment fee that can be charged is one month's salary, which can be charged to the employer but not to the jobseeker. Department of Labor approval is needed for an agency to operate branch offices. Job fairs can only be hosted by licensed agences. As of May 2018, there were 82 private recruitment agencies licensed in Myanmar. ${ }^{20}$ All but one of these agencies is headquartered in Yangon. The exception is headquartered in Mandalay. There is currently no association of licensed recruitment agencies. 
Licensed recruitment agencies generally identify workers through a combination of social media presence, name recognition, and print advertisements in publications like the Opportunity Journal. The agencies typically provide some level of job-search support, such as resume and interview instruction, to jobseekers. The agencies identify job vacancies by canvassing companies for job openings. Recruitment agencies typically charge employers for their services, and provide a guarantee that the worker will remain with the employer for a certain period of time.

Private job-search services for low-skilled jobseekers are is very limited. First, employers seem able to fill low-skilled positions on their own. Human resource departments tend to use their own networks to hire for low-skilled positions. These networks are supplemented by the social networks of employees and by informal brokers. Second, recruitment agencies report that there is high turnover in low-skilled jobs, which makes the typical business model of receiving payment from employers in exchange for a guarantee of a certain period of employment unworkable.

Informal brokers or agents are also involved in recruitment. These informal brokers are not registered with the Department of Labor. They operate similarly to formal firms but likely target lower-skilled jobseekers, operate in more rural areas, and charge jobseekers rather than employers for their services.

Online job-matching agencies provide services very similar to those provided by licensed recruitment agencies. Online jobmatching agencies do not have recruitment agency licenses, ${ }^{21}$ and provide online platforms rather than in-person services to match jobseekers and employers. There are between three and five main players in the online job matching market, which does not seem to be growing; these include MyJobs and JobNet. About 1,000 companies post their jobs online to these services. Providers of online jobmatching services compile databases of jobseeker resumes and online vacancy advertisements. As resume and vacancy databases grow, providers are better able to match jobseekers with employers, and the additional data on jobseekers and job vacancies helps improve matching algorithms. Employers typically pay a (small) fee to post a job advertisement, and then pay an additional fee for access to resumes and assistance with filtering them for their needs. Jobseekers are typically able to register, search for, and apply to jobs for free. The relatively new platform Neh Thit seeks to connect mid-skilled workers that have some level of higher education with jobs (for example, entry-level accountants). Neh Thit is using an automated chatbot to enhance its service delivery. Some licensed recruitment agencies also have an online portal where jobseekers can search for jobs (MyWorld has such a portal).

Many of the training programs of CSOs, NGOs, and international development agencies create linkages between graduates of their training courses and employers. Table 2.6 highlights the job matching and placement aspects of these programs.

\footnotetext{
20 This was a decline from 107 in mid-2017.

21 MyJobs, which operates an online job matching platform, has a separate affiliated entity, JPE Everest, that has a recruitment agency license.
} 
Table 2.6

Job-matching and -placement components in training programs led by CSOs, NGOs, and international development agencies

\begin{tabular}{|c|c|}
\hline Number & Examples of information reported \\
\hline Aung Myin Hmu & $\begin{array}{l}\text { The Aung Myin Hmu project provides job-matching services to women migrating } \\
\text { to Yangon for work in the garment sector. In practice, this job-matching service, the } \\
\text { GOOD chatbot, is more of an informational tool than a job-matching one. The GOOD } \\
\text { chatbot is described in detail in the text. }\end{array}$ \\
\hline $\begin{array}{l}\text { Linking Labutta to } \\
\text { Markets }\end{array}$ & $\begin{array}{l}\text { Linking Labutta to Markets, run by Mercy Corp and SwissContact in Labutta in the } \\
\text { Ayeyarwady Region, combines training in mechanics, garments, carpentry, masonry, } \\
\text { and hospitality with a job-matching service. A marketing officer partners with } \\
\text { employers to match job vacancies to trainees upon graduation. Most of the graduates } \\
\text { who have been placed in jobs have been placed in Yangon. }\end{array}$ \\
\hline $\begin{array}{l}\text { Skills for } \\
\text { Employment }\end{array}$ & $\begin{array}{l}\text { Helvetas's revamped Skills for Employment project in Magway Region replaced a } \\
\text { livelihoods-focused program that ran between } 2014 \text { and 2017. Building on lessons } \\
\text { learned from the livelihoods-focused program, an integral component of the Skills } \\
\text { for Employment project will be labor market assessments and employment plans } \\
\text { for trainees to match them with jobs. Helvetas is engaging employers in Magway, } \\
\text { but also in Yangon and other markets, in part because of the difficulty of attracting } \\
\text { employers in Magway to job fairs. }\end{array}$ \\
\hline $\begin{array}{l}\text { Vocational Skills } \\
\text { Development } \\
\text { Program (VSDP) }\end{array}$ & $\begin{array}{l}\text { The VSDP provides assistance with job matching and placement in its Local } \\
\text { Vocational Training (LVT) and Hotel and Tourism Industry (HTI) components. LVT } \\
\text { provides market- and employment-oriented basic-level training courses in masonry, } \\
\text { plumbing, sales, tailoring, rural mechanics, household electrical work, and beauty. At } \\
\text { the end of the training, the program offers its participants linkages with employers. A } \\
\text { job fair is held during the graduation ceremony, and businesses are invited to attend } \\
\text { and scout for employees. Graduates starting their own businesses are connected to } \\
\text { the social enterprise Entrepreneurship Development Network Asia (EDNA), which } \\
\text { provides business management training on topics such as starting a business and } \\
\text { managing cash flow. Six months after training completion, the LVT program creates } \\
\text { peer networks and facilitates the sharing of work experience among graduates. The } \\
\text { HTI program provides training to disadvantaged individuals in the hospitality sector. } \\
\text { The program involves training by hotel staff, and offers linkages with potential } \\
\text { employers in the hospitality sector after graduation. }\end{array}$ \\
\hline Twe Let & $\begin{array}{l}\text { IOM's Twe Let project includes job-matching support for graduates of its skills } \\
\text { development training. Local business associations have provided vacancies to IOM, } \\
\text { and the opening ceremonies of skills-training courses are used to help connect } \\
\text { jobseekers and employers. IOM is also considering organizing job fairs. Collaboration } \\
\text { with LEOs is currently limited, although Twe Let provides updates on its activities; } \\
\text { Twe Let and LEOs are exploring ways to work together. }\end{array}$ \\
\hline
\end{tabular}

Source: Authors. 


\section{Areas for improvement and potential gaps}

Jobseekers in Myanmar primarily use informal methods to look for employment. Only 6 percent of jobseekers report applying for a jobseeker registration card at Labor Exchange Offices, while the vast majority (70 percent) report looking for jobs through personal networks (Cunningham and Muñoz 2018). This pattern is apparent throughout Myanmar. A survey of internal migrants in 14 states and regions found that nearly three-quarters of internal migrants had received some type of recruitment assistance from others (Figure 2.2). The majority received support from friends, family, or acquaintances. Only a small fraction used a broker. Intermediaries are typically not required for the traditional internal migration routes (such from the Dry
Zone to tea plantations in Shan, or from the Delta and Dry Zone to rubber plantations in the Southeast) as relationships between employers and migrant workers are well established. However, as these routes are becoming less profitable, and new routes are emerging, social networks and brokers become more important for job searching in new destinations (Maharajan and Myint 2015; World Bank and CESD 2018). Most aspiring migrants migrate only after acquiring information about a job situation, and many migrate only after securing a job. For instance, in Ayeyarwady and Magway, 80 percent of aspiring migrants found out about their jobs, mostly from fellow villagers (Pattison et al. 2016b). About 58 percent of aspiring migrants in Ayeyarwady and 34 percent in Magway had already secured jobs before leaving, mostly through family or relatives in destinations like Yangon.

Figure 2.2

Type of recruitment assistance used by internal migrants

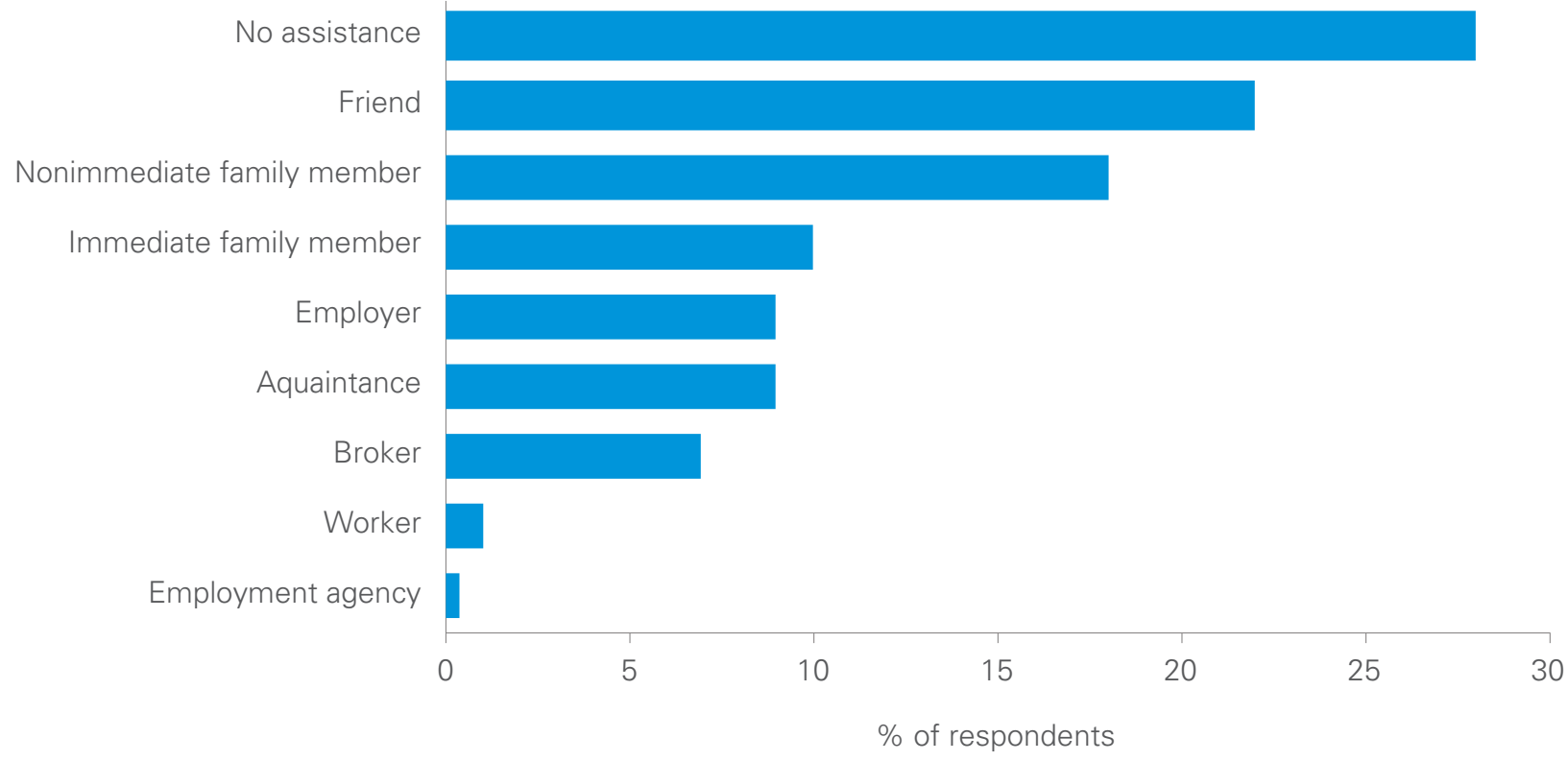

Source: ILO 2015a. 
While recruitment agencies and brokers can make migrants aware of more opportunities, many brokers are unlicensed, exposing migrants to exploitation and trafficking. Brokers are often used to help facilitate internal migration, particular by introducing migrants to potential employers in the destination location. However, a study of internal migrants in 14 states and regions found more instances of exploitation and trafficking when migrants used unlicensed agents than when they used known contacts (ILO 2015a). Even among those planning to use brokers or agencies, most aspiring migrants consider family and friends more trustworthy. About 40 percent of respondents in Ayeyarwady and Magway were concerned about being cheated by an agent, while over a third expressed concerns about human trafficking (Pattison et al. 2016b). This concern was voiced despite the relatively low number of such cases reported: about 3 percent of migrants in Ayeyarwady reported being forced to work without pay or being trafficked, and 1 percent of migrants in Magway reported exploitation by agents. This may be because these regions have a long history of migration and well-established social networks, which mitigate the risks of migration. However, trust in brokers was higher in places where a larger share of migrants had used their services (as in Mandalay) (ILO 2015b).

Providing effective and efficient public job-matching and -placement services is particularly important because private providers of these services tend to focus only on more highly skilled workers, leaving less-skilled workers reliant on social networks, which may have limited or skewed information about available jobs, and on informal brokers who are potentially exploitative (see International Spotlights 9 and 10 in Chapter 4.) The jobmatching function of LEOs is limited by other demands on staff time, and human resource and financial constraints; for example, LEO staff and employers are required to fill out multiple forms, although in practice these forms are not always used. No analysis seems to be done on the information collected to reveal labor market trends that could inform future job matching. Additionally, all job matching is done manually by LEO staff based on the limited information provided by jobseekers and employers. The limited number of vacancies registered at some LEOs also limits the effectiveness of job matching. As a result, few workers rely on the employment services provided by LEOs. As noted above, only 6 percent of jobseekers report applying for their jobseeker registration card, while the vast majority (70 percent) report looking for jobs through personal networks (Cunningham and Muñoz 2018).

At the same time, there may be space for the Department of Labor and LEOs to take a more active role in managing private providers of these services. A system for licensing internal employment agencies is in place in Myanmar. However, LEOs are not actively engaged in the oversight of employment agencies. This is partly by design: LEOs are supposed to be responsible for job matching, not recruitment oversight. LEOs do investigate informal brokers, but only after complaints are received. The lack of active oversight may create space for informal brokers to flourish. Plus, the lack of information about employment opportunities in urban areas likely contributes to jobseekers' reliance on informal brokers to provide this information to residents of rural areas. Additionally, there are few channels that provide information about the quality of recruitment agencies. The Department of Labor publishes a list of these agencies, but it does not provide information about their quality, including their success in placing jobseekers in employment. 
Jobseekers and employers face cumbersome procedures at LEOs with few benefits in return. Jobseekers are required to register in person at a LEO for a jobseeker registration card. The NRC is a minimum requirement for jobseekers to register, but many people lack this documentation. A survey of internal migrants in 14 states and regions found that 22 percent of respondents did not possess an NRC (ILO 2015a). Procedures for transferring labor cards across locations within Myanmar are cumbersome, such that most workers prefer to get new labor cards issued at their migration destination. Employers are also expected to register and post job vacancies at LEOs but rarely do so, and instead mostly rely on informal recruitment channels. Also, LEOs are not easy to access, especially for people from outside the cities where LEOs are located (World Bank and CESD 2018). As described above, the labor market information and job-matching and -placement services provided to jobseekers and employers who do register are very limited. As a result, few jobseekers use the employment services provided by LEOs. Jobseekers can face additional administrative hurdles; for example, some studies have found that internal migrants must register with local authorities before starting work, regardless of whether they are temporary or permanent migrants (Maharajan and Myint 2015).

\section{Financial assistance}

Accessing jobs involves costs, although the costs of migrating internally are fairly low. Costs faced by internal migrants, which are generally borne at the outset of migration, include transportation to the destination, documentation, and initial housing and job searches at the destination. Many migrants mitigate some of these financial constraints by using social networks to identify jobs and housing before leaving. The upfront costs of migrating to jobs inside Myanmar can be quite low. For instance, about 66 percent of households with internal migrants in Magway and Ayeyarwady report migration costs to be less than MMK40,000 (approximately

\section{Internal migration is typically financed through own savings or with help from family}

US\$30) (Pattison et al. 2016b). These findings are corroborated by other studies (Maharajan and Myint 2015).

Internal migration is typically financed through own savings or with help from family. For instance, 43 percent of households in Ayeyarwady and 33 percent in Magway used their savings to finance internal migration, while another 28 percent and 19 percent borrowed from family in the two regions (Pattison et al. 2016b). A 2017 household survey found a much smaller share of internal migrants using their own savings, with the majority relying on friends and family for financial assistance (Deshingkar, Litchfield, and Ting 2019). This can be explained by the relatively low cost of internal migration.

Financial assistance is provided by NGOs, CSOs, and international development agencies to promote livelihoods and selfemployment, but is generally not offered for job searching or wage employment. 
Several of the training programs described above provide stipends to beneficiaries during training. Job search support is also provided, but generally in the form of support services rather than in the form of financial assistance. However, NGOs, CSOs, and international development agencies have provided financial assistance for livelihood interventions that promote self-employment-examples include vocational skills development programs that provide beneficiaries with a livelihood grant or a self-employment starter kit after the program's conclusion. This approach has been implemented in conflict-affected areas where livelihood opportunities are limited. At present, there are few public programs or programs run by NGOs, CSOs, or international development agencies that provide subsidies for job searches or employment.

\section{Conclusion}

Myanmar's system for delivering ALMPs faces significant human and financial resource constraints, which are likely to persist. This chapter has pointed out areas where the delivery processes are overly burdensome (for example, the manual registration of jobseekers at LEOs) and where information management is ineffective. Streamlining these processes along with modest investments in information technology could improve the delivery of ALMPs. As for the significant gaps in labor market information, it is important to harness the existing sources of that information-for instance, through partnering with private providers of online job-search services. Improving business processes related to jobseeker and job vacancy registration could also help transform that data into a valuable source of insights into the labor market. Finally,

\section{Areas for improvement and potential gaps}

There is no financial assistance or financial products devoted specifically to helping workers find jobs in Myanmar (see International Spotlight 14 in Chapter 4). However, an innovative product targeted to internal migrants who have already migrated is being tested in Yangon. The product is designed to ease the integration of internal migrants into their new social and economic context. VisionFund Myanmar is currently offering a microfinance loan to garment factory workers in Yangon. Garment factory workers can access loans up to MMK500,000 to support themselves after migrating to Yangon. VisionFund reports that the average loan amount will be 20 percent of a migrant's monthly salary at an interest rate of 2.5 percent.

releasing the Labor Force Survey more broadly would expand the information available on the labor market at a very low cost, since the survey is already being conducted. Overall, more engagement with the private sector would be a costefficient way to improve the delivery of services. Skills-training programs currently lack input from the private sector, which is key to the effectiveness of those programs. Improving the registration of vacancies at LEOs would likely be more successful through a partnership with the private sector rather than by trying to enforce a mandatory requirement. Table 2.7 summarizes examples of ALMPs from other countries that are relevant for strengthening ALMPs in Myanmar. These examples are discussed in more detail in Chapter 4. 
Table 2.7

\section{Relevant examples of ALMPs from around the world}

\begin{tabular}{|c|c|c|c|}
\hline Area & Program name & Country & Description \\
\hline 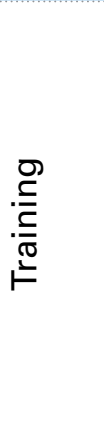 & $\begin{array}{l}\text { Rural Migrant Skills } \\
\text { Development } \\
\text { and Employment } \\
\text { Project }\end{array}$ & China & $\begin{array}{l}\text { - Helped improve the training provided to internal } \\
\text { migrant workers by developing competency-based } \\
\text { curricula, preparing instruction materials, and training } \\
\text { instructors to provide skills training according to } \\
\text { industry demand and the learning needs of migrant } \\
\text { workers. The project also improved accreditation } \\
\text { standards, financed subsidies to support migrant } \\
\text { training, and provided information on training } \\
\text { opportunities. }\end{array}$ \\
\hline 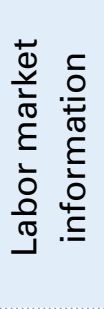 & $\begin{array}{l}\text { Dissemination } \\
\text { of labor market } \\
\text { information }\end{array}$ & $\begin{array}{l}\text { Dominican } \\
\text { Republic, Ethiopia, } \\
\text { Madagascar, Peru, } \\
\text { the Philippines, } \\
\text { Thailand, the United } \\
\quad \text { States }\end{array}$ & $\begin{array}{l}\text { - A variety of interventions to provide labor market } \\
\text { information have led to improved employment } \\
\text { outcomes, more accurate expectations about jobs, } \\
\text { and increased schooling. }\end{array}$ \\
\hline & $\begin{array}{l}\text { Rural Migrant Skills } \\
\text { Development } \\
\text { and Employment } \\
\text { Project }\end{array}$ & China & $\begin{array}{l}\text { - Established employment service centers in } \\
\text { rural areas and helped extend the labor market } \\
\text { information system to include local areas. An urban- } \\
\text { rural management information system was created } \\
\text { that contains information to match jobseekers to job } \\
\text { opportunities. }\end{array}$ \\
\hline & $\begin{array}{l}\text { Recruitment } \\
\text { services in the } \\
\text { business process } \\
\text { outsourcing } \\
\text { industry }\end{array}$ & India & $\begin{array}{l}\text { - Recruitment sessions provided information } \\
\text { about the business process outsourcing industry, } \\
\text { strategies for applying to jobs, interview lessons, an } \\
\text { assessment of English language skills, and } 3 \text { years } \\
\text { of job placement support to young women in rural } \\
\text { areas, increasing the likelihood of entering the labor } \\
\text { market or obtaining more schooling or training. }\end{array}$ \\
\hline 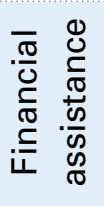 & No Lean Season & Bangladesh & $\begin{array}{l}\text { - Travel subsidy of US } \$ 20 \text { to rural laborers so that a } \\
\text { household member could look for work during the } \\
\text { lean season; this program had positive impacts on } \\
\text { income and consumption. }\end{array}$ \\
\hline
\end{tabular}

Source: Authors 


\section{References}

Cunningham, Wendy, and Rafael Muñoz. 2018. Myanmar Future Jobs: Embracing Modernity. Yangon: World Bank.

Deshingkar, P., J. Litchfield, and Wen-Ching Ting. 2019. "Capitalising Human Mobility for Poverty Alleviation and Inclusive Development in Myanmar (CHIME)." International Organization for Migration, Yangon.

ILO (International Labour Organization). 2015a. “Internal Labour Migration in Myanmar: Building an Evidence-base on Patterns in Migration, Human Trafficking and Forced Labour." International Labour Organization, Yangon.

ILO. 2015b. "Safe Migration Knowledge, Attitudes and Practices in Myanmar. Tripartite Action to Protect the Rights of Migrant Workers within and from the Greater Mekong Subregion (GMS TRIANGLE project)." International Labour Organization, Bangkok.

ILO. 2017. "ILO Guide to Myanmar Labour Law 2017," ILO, Yangon.

Luther. 2017. “Memo: Myanmar Employment Law," Luther, Yangon.

Maharajan, A., and T. Myint. 2015. "Internal Labor Migration Study: In the Dry Zone, Shan State and the Southeast of Myanmar." HELVETAS Swiss Intercooperation Myanmar, Yangon.

Milio, Simona, Elitsa Garnizova, and Alma Shkreli. 2014. "Assessment Study of Technical and Vocational Education and Training (TVET) in Myanmar," International Labour Organization (ILO), Bangkok.

Pattison, C., J. Voss, A. Woodhouse, and M. Zurstrassen. 2016b. "A Country on the Move: Migration Networks and Risk Management in Two Regions of Myanmar." World Bank, Yangon.

UNESCO. 2019. "TVET System Review: Myanmar." Paris, UNESCO.

UNESCO-UNEVOC International Centre (UNESCO-UNEVOC International Centre for Technical and Vocational Education and Training). 2018. "TVET Country Profile: Myanmar," UNESCOUNEVOC, Bonn.

World Bank. 2018. "Using Targeted Labor Market Information Tools To Improve Employment Services in Vietnam," World Bank, Washington D.C.

World Bank and CESD (Centre for Economic and Social Development). 2018. "Rapid Field Assessments in Ayeyarwady, Bago, Magwe, Mandalay, Mon, Kayin, Tanintharyi and Yangon." World Bank, Yangon. 


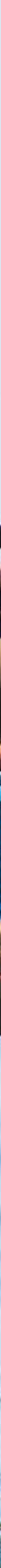

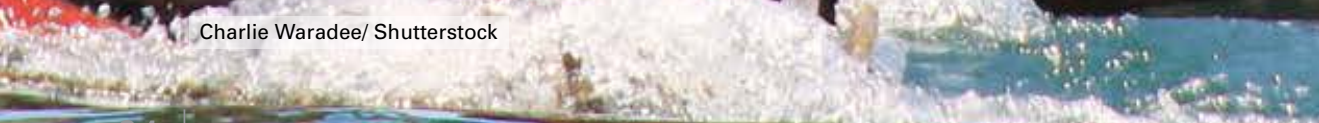




\section{CHAPTER}

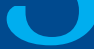

\section{Active Labor Market Policies for Myanmar Workers Abroad}

M yanmar's system for managing active labor market policies (ALMPs) for international jobseekers has matured in recent years, but it still faces significant challenges. Migrant Resource Centers (MRCs) have been developed to support international migration, and efforts have been made to simplify the process of migrating to Thailand, the most popular destination for Myanmar migrants moving outside of the country. However, financial and human resource constraints are present in the migration system. This is apparent in the Labor Exchange Offices (LEOs) where a lack of budget and staff means that officers perform multiple functions that range from manual data entry to job matching for jobseekers, and the extent to which they can provide support to international migrants and their families is therefore limited. Regulations related to ALMPS make migration time-consuming and costly; actors in the migration system must comply with these procedures, but that compliance does not make the process significantly safer or more beneficial. This includes the high-level oversight of demand letters and the multi-step process of migrating to Thailand mandated under the Myanmar-Thailand Memorandum of Understanding (MOU). The systems for managing the intake, storage, and transfer of information related to migration are underdeveloped, including the management of demand letters, the registration of jobseekers at LEOs, and the assignment of Overseas Worker Identification Cards (OWICs). While nascent information management systems exist, data input and information transfer are frequently done manually. At the same time, there are limited sites where international migrants can obtain information about job openings and about the recruitment agencies that are integral to the job-search process for international migrants.

There are also several gaps in services provided to migrants; for example, financial services targeted to migrants, reintegration programs to support returning migrants, and engagement with the Myanmar diaspora to tap into their knowledge and skills. MRCs can be the key institutions supporting migrants and their families, however, they suffer from limited resources and coverage, on the one hand, and a broad mandate, on the other. The low uptake of MRC services by migrants suggests that the system is not reaching its target audience. 


\section{Introduction}

Active labor market policies (ALMPs) have the same objective for international jobseekers as for domestic jobseekers: to generate more and better employment opportunities for workers. The instruments to achieve those objectives are somewhat different for international jobseekers; adjustments must take into account the greater cost and distance typically involved with international migration, and risks that arise because policy in destination countries can only be influenced and not changed directly.

As in Chapter 2, this chapter focuses on four main types of ALMPs, but focuses on how they are targeted to international jobseekers. Training is designed to improve the employability of jobseekers by helping them obtain skills that are relevant in the labor market. This includes training in technical skills, in softs skills, and in digital or technology-specific skills. In the context of international migration, training also tends to include courses preparing potential migrants for the process of migrating safely and about what to expect when working abroad. Labor market information, including about labor demand, labor supply, labor market intermediaries, labor market policy, and labor conditions is useful for jobseekers looking for jobs, and to other labor market stakeholders, like employers, educational institutions, and training providers that use this information to inform decision making. In the context of international migration, labor market information also includes details about the process of accessing jobs abroad, which can be much more complex than accessing jobs domestically. Job-matching and -placement services take an active role in matching individual jobseekers to individual jobs. In the context of international migration, job matching and placement tends to focus less on ensuring the quality of matches between workers and employers and more on managing the process of connecting labor demand in a destination country with labor supply in a sending country. Finally, financial assistance includes policies that help alleviate the capital constraints to obtaining jobs. In the context of international migration, these policies include subsidies and loans that help finance migration. As noted in Chapter 2 , these different areas of ALMPs often overlap. For instance, information about migration processes and procedures are a key input to the training programs provided to migrants before they depart for jobs abroad.

\section{Legal and institutional framework}

The legal and institutional framework governing international migration is an important determinant of how well jobseekers find jobs abroad. Myanmar, like many countries, has created a substantial legal, institutional, and regulatory framework that governs how jobseekers search for jobs, connect with employers abroad, work abroad, and return home (this chapter devotes more attention to this framework than Chapter 2). The section that follows is divided into the strategic planning related to migration, the legislation governing migration abroad, the institutions involved in migration, and the regulations that dictate who can migrate abroad for jobs. 


\section{Strategic planning}

Myanmar has developed two five-year strategic plans for international migration. Myanmar's Department of Labor worked with the International Organization for Migration (IOM), the International Labor Organization (ILO), other international development agencies, and civil society organizations (CSOs) to develop a national strategy for international migration. The resulting Five-Year National Plan of Action (NPA) for the Management of International Labor Migration in Myanmar (2013-2017) was a series of strategic areas, policy options, and action plans. The NPA covered each stage of the migration process, as well as the legislative and institutional frameworks that determine how migrants experience this process. The NPA provided concrete action plans in each of the strategic areas covered. The Department of Labor is now implementing the Second Five-Year National Plan of Action on the Management of International Labor Migration (20182022). As with the first NPA, the second NPA takes a comprehensive approach to labor mobility in Myanmar. The Plan has three pillars, each of which focuses on a different set of actors in the migration system. The Empowerment and Protection of Migrant Workers pillar focuses on the migrants themselves; the Increasing the Development Benefits of Labor Migration pillar focuses on Myanmar and its people (families and returned migrants in particular); and the Improving the Governance and Administration of Labor Migration pillar focuses on the government. Each pillar includes objectives and actions to achieve those objectives, with the overarching goal of improving migration management.

Several other national strategic plans mention migration. The Myanmar Sustainable Development Plan (20182030), a national strategy to inform policies and institutions to drive inclusive and transformational economic growth, includes components related to migration. One of its three pillars-People and Planetincludes a strategic area for protecting the rights and harnessing the benefits of work, including for migrant workers. Several of the actions proposed in this strategic area relate specifically to international migrant workers, including improving the crossborder financial services for them and their left-behind families and measures to encourage the diaspora's contribution to economic development. Two other actions relate to migrant workers more generally: promoting legal, affordable, and secure migration services to increase migration's contribution to development and protecting labor rights through safe and secure working environments to increase productivity. The National Strategic Plan for the Advancement of Women (2013-2022) mentions female migrants in sections on research and policy making. Myanmar also developed a National Plan of Action to Combat Human Trafficking. The National Social Protection Strategic Plan mentions migration and trafficking as examples of risks and vulnerabilities that social protection can help mitigate.

\section{Areas for improvement and potential gaps}

Myanmar's second NPA has several strengths, such as recognizing the migration-development nexus and the importance of local involvement in the governance of migration. For example, the new plan highlights the potential to increase the role of LEOs and MRCs in the recruitment process as a way to reduce migration costs and to expand access to employment opportunities abroad. It also lays out a plan for monitoring and evaluating progress on the targets established in the plan, which the first NPA did not do. Of its 
weaknesses, the second NPA does not prioritize its action plans. Each policy action is assigned a timeframe for completion ranging from 1 to 5 years. The drawback of this approach is that progress on all of the 95 actions within that timeframe seems unrealistic, and even undesirable, given the constraints on time and resources. Indeed, a draft midterm review of the first NPA found that many of the 109 actions were not completed in the 5-year timeframe.

\section{Legislative framework}

The Law Relating to Overseas Employment (1999) (LROE) establishes the Overseas Employment Central Committee for the formulation of migration policy and the Overseas Employment Supervisory Committee for its implementation. The law sets out the duties and rights of workers seeking employment abroad and, along with Ministerial Order 560/2014, establishes procedures for licensing overseas employment agencies, which are private firms that match jobseekers in Myanmar with jobs abroad. The LROE is currently undergoing a process of review and revision. Myanmar passed an anti-trafficking law, the Anti-Trafficking in Persons Law, in 2005. The law includes provisions to prevent and investigate trafficking in persons, including through the establishment of a Central Body for the Suppression of Trafficking in Persons and a specially trained police force. The law sets out punishments for trafficking, and includes special protections for women and children and young people, and provisions related to repatriation, reintegration, and rehabilitation.

Myanmar has signed two MOUs on migration with Thailand, which is the most important destination country for Myanmar migrants. Myanmar signed a first MOU with Thailand in 2003, which became active in 2009. As with Thailand's MOUs with Cambodia and Lao PDR, the MOU with Myanmar covered all aspects of the migration process, from admissions into Thailand to employment while in Thailand to exit from Thailand after the conclusion of employment, and it paid particular attention to preventing irregular migration. This MOU helped facilitate a regularization and documentation process for irregular migrants from Myanmar (the nationality verification process in Thailand). Myanmar signed a new MOU with Thailand in 2016. The latest MOU is somewhat more broad, covering issues of skills development and reemployment (ILO 2016b). The MOU outlines the agreement between Myanmar and Thailand to exchange information, cooperate on skills development, and work to enhance the transparency and efficiency of the migration process. Coordination of the Thai MOU involves many agencies in Myanmar, including the Ministry of Labor, Immigration, and Population (MOLIP), the Ministry of Home Affairs and its AntiTrafficking in Persons Division, the Ministry of Foreign Affairs, the Ministry of Border Affairs, the Police Special Branch, and the Myanmar Overseas Employment Agencies Federation (ILO 2017). Meetings with Thai authorities occur regularly with technical meetings every three months (ILO 2017).

Details of the migration process to Thailand are outlined in an agreement that accompanies the MOU. The Agreement on the Employment of Workers defines migration procedures related to employment requests by Thailand and the fulfillment of those requests by Myanmar. The Agreement also outlines protections for migrant workers, including entitlement to protection under Thailand's labor law. Employment terms are set at 2 years, extendable for an additional 2 years, at which point migrants must return to Myanmar for a cooling-off period of 30 days-a significant reduction from 
the 3-year cooling-off period required in the $2003 \mathrm{MOU}$. Migrants may not switch employers during their employment, unless the employer is "unable to protect the worker according to the existing laws" or if the employer closes their firm. The Agreement outlines the responsibilities of employers, such as furnishing a copy of the employment contract to workers, which must be in Thai, Myanmar, and English; providing proper accommodations to workers; and notifying the Myanmar Embassy if a worker is injured or dies. The Agreement also specifies the responsibilities of employees, such as paying taxes. Myanmar is mandated to provide migrant workers with a free orientation on the employment contract and with information about Thailand, including their rights while there. The Agreement also requires employers to notify Thai authorities when migrant workers leave employment, and requires Thai authorities to notify Myanmar authorities in turn. A joint working group is to hold regular meetings at least quarterly. The Agreement is in force for two years and renewable by mutual consent. Myanmar also recently signed an MOU with Thailand on the employment of border migrants. These migrants can obtain a 30-day work pass.

Myanmar has signed MOUs with several other countries. Myanmar signed a MOU with Korea in 2007 to participate in Korea's Employment Permit System (EPS). Myanmar also signed a bilateral agreement with the Japan International Training Cooperation Organization in 2013, although use of this migration channel has been limited. MOLIP signed a new Memorandum of Cooperation (MOC) on the Technical Intern Training Program in
2018 with Japan's Ministries of Justice, Foreign Affairs, and Health, Labor, and Welfare. This agreement governs the migration of Myanmar workers to work in Japan's Technical Intern Training Program, which is active for 5 years with an automatic 5-year extension. The agreement includes protections related to accommodations and fees. In 2019, the Government of Myanmar announced that workers who passed skills and Japanese language proficiency tests, and had 3 years of related work experience, would be able to work in Japan. ${ }^{1}$ Finally, Myanmar signed a Collaboration Agreement for Registration, Legalization, and Deportation of Undocumented Myanmar Workers with Malaysia in 2013, and had been in discussions for an MOU before a ban was imposed in late 2016 on sending workers to Malaysia (ILO 2014a; Oo 2016).

Myanmar participates in several multilateral bodies related to migration. These include the Global Forum on Migration and Development and the Bali Process on People Smuggling, Trafficking in Persons and Related Transnational Crime. Myanmar is also a signatory to the ASEAN Consensus on the Protection and Promotion of the Rights of Migrant Workers, signed in late 2017.

\section{Areas for improvement and potential gaps}

The LROE emphasizes the importance of coordination across agencies, and it lays out many of the responsibilities necessary for the effective management of migration. However, there are several areas for improvement: The Overseas Employment Central Committee (OECC), the highest

\footnotetext{
1 Migrants would be able to work in caregiving, building cleaning, machine parts and tooling, industrial machinery, electrical work, electronics and information technology, construction, shipbuilding and ship machinery, automobile repair and maintenance, aviation, hospitality, agriculture, fisheries and aquaculture, food and beverage manufacturing, and food services. See Htwe, Zaw Zaw. "Japan offers jobs in 14 industries." Myanmar Times, August 1, 2019.
} 
level coordination body established by the LROE, does not seem to meet regularly. While the Overseas Employment Supervisory Committee (OESC) seems to have taken on the functions of the OECC, the limited role of the OECC suggests that the LROE could be updated to better reflect current needs in migration management. Additionally, there are several gaps in the LROE. The LROE does not include provisions related to services for international migrants, such as information provision, reintegration, or legal assistance. A system for managing information related to migration is also not included. There is no mention of local, region, or state authorities, such as LEOs and state and region offices of the Department of Labor, which could participate in migration management. This leaves a potential hole in coordination between national and subnational authorities working on issues related to international mobility. The LROE also lacks any provisions related to how the law, and particularly its provisions related to licensing overseas employment agencies, should be enforced. Finally, the legislation does not offer a complaints mechanism or a single authority that is responsible for receiving and adjudicating complaints from migrant workers.

Myanmar's 2003 MOU with Thailand established the first formal, legal process for workers migrating to Thailand. The 2016 MOU represents a continuation of that effort. Importantly, the MOU has created a platform for Myanmar and Thai authorities to meet regularly to discuss issues related to migration between the two countries. That being said, the process of migrating to Thailand via the MOU is lengthy and complex, and it requires several months. One estimate of the time to migrate under the previous MOU was 89 days and 25 steps (ILO 2015a); migration involves many agencies and many verification steps (see Online Appendix 4). These steps seem to be more influenced by national security concerns and less influenced by the practical needs of migrants (ILO 2017).

The high cost of the MOU process means that the majority of migrants still use irregular channels (UNTWG 2019). This is an area for improvement, but it requires commitment from both the Myanmar and Thai governments. Systems to transfer information within Myanmar and between Myanmar and Thailand contribute to the time-consuming process. Currently, the process involves many manual stages in which, for instance, recruitment agencies must provide demand letters in person or mail demand letters to the Migrant Worker Division. The demand letter is passed back and forth between the Myanmar and Thai authorities to obtain the necessary approvals. Additionally, information included in the demand letters must be entered into a computer system manually to share with the Education, Health, and Human Resources Development Committee, and not all information included in the demand letters is captured in the computer system. The lack of an information management system makes data sharing more challenging.

\section{Institutional framework}

Many institutions are involved with different aspects of the migration system in Myanmar. Figure 3.1 provides an overview of the public migration-related institutions. Private sector actors, as well as CSOs, nongovernmental organizations (NGOs), and international development agencies, are also involved in the management of international migration.

MOLIP is the primary ministry responsible for overseeing the international labor migration of Myanmar's citizens. The ministry facilitates overseas labor migration 
through its implementation of the LROE and the coordination of other government actors on matters related to migration. The Ministry's Department of Labor coordinates the NPA. Outside of MOLIP, the Ministry of Home Affairs and the Ministry of Foreign Affairs are involved in the creation and coordination of bilateral agreements. The upper house of Myanmar's legislature, the House of Nationalities (Amyotha Hluttaw), formed the Parliamentary Committee on Local and Overseas Workers in its 2013 and 2016 sittings. While its responsibilities are still being defined, the core work of the committee will involve settling labor disputes with MOLIP, working on procedures for addressing worker grievances, and amending and supplementing labor laws (ILO 2017).

MOLIP coordinates migration policy through its chairmanship of the OECC. The LROE established the OECC as the main policy-making body for outmigration related issues. According to the LROE, the OECC is to be chaired by MOLIP. Members are from other relevant ministries and departments and individuals from outside the government who are knowledgeable about labor affairs. The committee is responsible for coordinating policy implementation and the protection of migrant workers; giving guidance on the reintegration of returned migrant workers; determining countries, employers, and work that is unsuitable for employment abroad; providing guidance on licensing of recruitment agencies; and determining the fee that recruitment agencies are permitted to charge for their services.

In practice, another interministerial committee the OESC established by the LROE is more active than the OECC in coordinating and supervising migration policy. In fact, the Minister of MOLIP now chairs the committee (ILO 2017). As with the OECC, members are from government departments and individuals who are experts in matters related to labor. The OESC currently includes MOLIP; the Ministry of Home Affairs; the Ministry of Border Affairs; the Ministry of Foreign Affairs; the Ministry of Planning, Finance, and Industry; the Ministry of Social Welfare, Relief, and Resettlement; and the Ministry of Transport and Communications. The committee is responsible for facilitating access to overseas employment opportunities and overseeing the protection of migrant workers; recruiting and selecting workers for overseas employment and coordinating skills and other training; issuing licenses to recruitment agencies; facilitating the reintegration of returned migrant workers; overseeing registration of prospective migrant workers; investigating employment opportunities abroad; and supervising recruitment fees.

The structure of the OESC was reformed in 2011. The 2011 reform created three subcommittees, each with an advisory body of experts (Win 2015). A recent report from the ILO describes the functions of each of the subcommittees (ILO 2017). The administrative subcommittee is chaired by the Deputy Minister of MOLIP and vice-chaired by the Deputy Minister of Home Affairs. This subcommittee is responsible for bilateral agreements, predeparture information, job offers and employment contracts for migrants, and fees and taxes. The workers' benefits subcommittee is chaired by the Deputy Minister of Planning and Finance and vicechaired by the Deputy Minister of Foreign Affairs. This subcommittee is responsible for areas related to financial services for migrants, including loans, insurance,

2 MOLIP was formed from the merger of the Ministry of Labor, Employment, and Social Security and the Ministry of Immigration and Population in 2016. 
and remittances. The workers' rights protection subcommittee is chaired by the Deputy Minister of MOLIP and vice-chaired by the Deputy Minister of Foreign Affairs. This subcommittee is responsible for labor attachés, efforts to protect migrant workers

while they are abroad, and the return and repatriation of migrant workers.

The Department of Labor oversees the Migrant Worker Division, which is directly responsible for the implementation of

\section{Figure 3.1}

\section{Migration-related institutions in Myanmar}

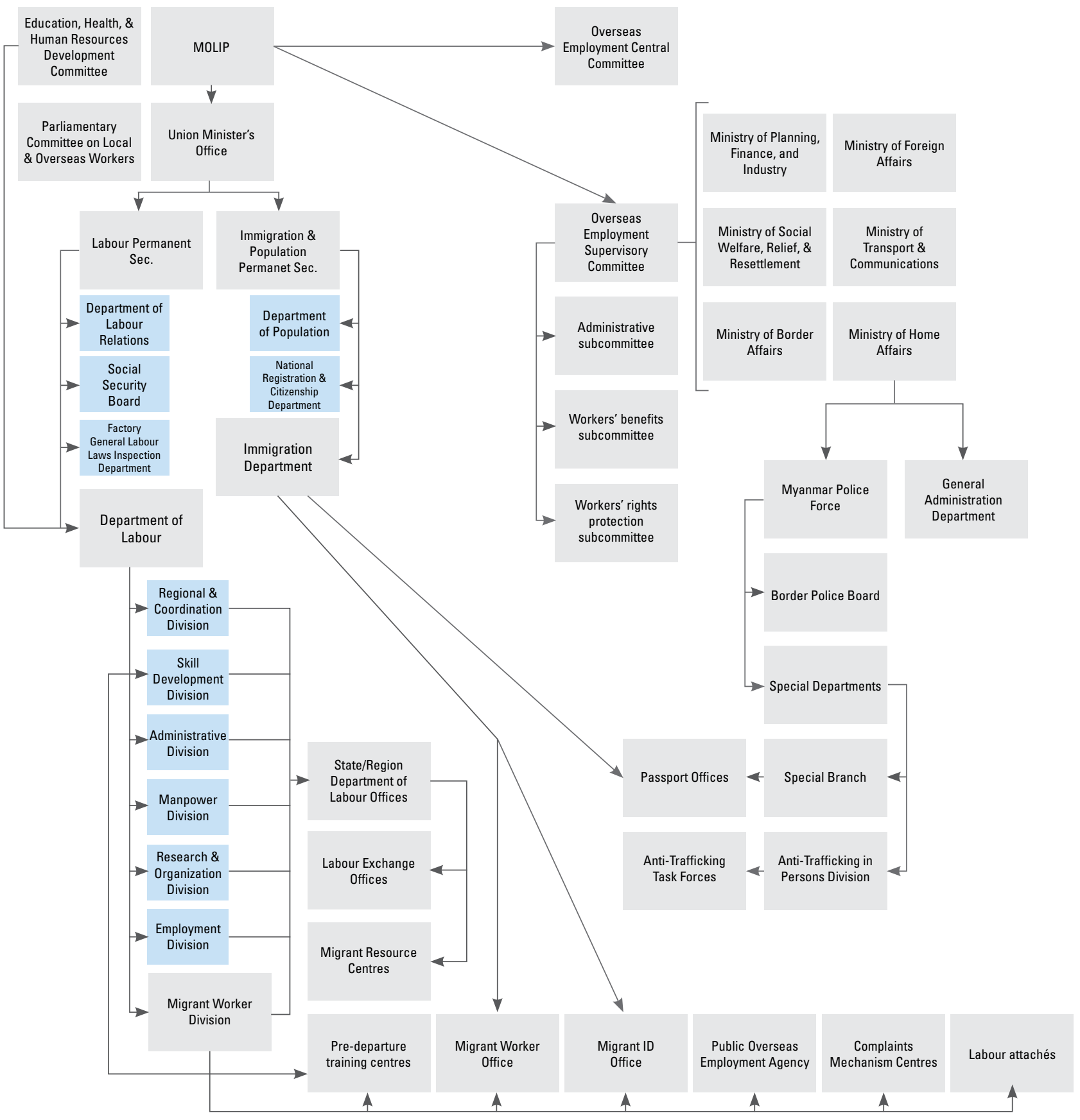

Note: Blue boxes indicate not directly involved with migration management.

Source: Authors. 
international migration policy. The Migrant Worker Division ${ }^{3}$, which was created in 2012, also provides expertise and inputs for planning and policy making at the departmental or ministerial level, including being the focal point for revising the LROE (ILO 2017). The Migrant Worker Division's main tasks are to facilitate the formal migration process, to oversee the recruitment process, and to help migrants benefit from migration. The Division is responsible for reviewing overseas employment requests from recruitment agencies, for approving and regulating licenses for these agencies, and for conducting predeparture training. The Migrant Worker Division is divided into staff responsible for overseeing migration to Thailand; for migration to all countries other than Thailand; and for migration to the Republic of Korea, under that country's Employment Permit System (EPS); for grievances; for international relations; and for administrative tasks. Of the 62 people in the Migrant Worker Division, approximately half are based in Nay Pyi Taw, while the other half are performing functions outside of the capital, such as assisting with the administration of Korea's Employment Permit System.

The Migrant Worker Division is responsible for providing services to international migrants. These services range from recruitment services to support for migrants while they are abroad.

- The Migrant Worker Division has eight labor attachés: five in Thailand, two in Malaysia, and one in Korea. These attachés are responsible for assessing the employers that request Myanmar workers and for responding to issues arising with migrant workers while they are abroad. The labor attachés must be under 45 years old. Those wishing to be a labor attaché must pass an examination that tests their experience and English language abilities. Individuals with experience, knowledge, and competent skills are prioritized during the selection process. The test is the same for Korea, Malaysia, and Thailand, since the applicants do not know at this stage where they will be placed. Once selected for a specific destination country, the labor attaché is provided with materials about that country's laws and culture. The labor attaché in Malaysia attends meetings with government agencies along with attachés from other countries to discuss problems facing migrant workers, such as compensation and employers confiscating migrant workers' passports.

- The Migrant Worker Division opened Complaints Mechanism Centers in 2013 in Yangon at the region Department of Labor office, and in Nay Pyi Taw at the Union Department of Labor office, to respond to the complaints of internal and international migrants. The Complaints Mechanism Centers are managed by the OESC. The labor attachés are an important component of this complaints mechanism system.

- The Public Overseas Employment Agency (POEA) was created in 2010 to handle the recruitment of migrant workers for Korea's Employment Permit System, which requires public recruitment for participation.

- MigrantWorkerReporting Counterswere established in Yangon's International Airport in July 2014 to track the departure and return of migrant workers, but they were closed on August 19th, 2018. The Departure Counter produced a daily report of departing migrant workers, and

3 See https://www.mol.gov.mm/mm/departments/department-of-labour/migrant-division/ (last accessed January 14, 2018). 
the data collected was managed by the Department of Labor. Workers returning to Myanmar checked in at the Arrival Counter.

The Migrant Worker Division oversees 15 MRCs (Table 3.1). The MRCs offer information and support services to migrants before departure and after return. The MRCs are supported by the ILO in Mandalay, Meiktila, Myingyan, and Kyaukse (Mandalay Region), in Dawei (Tanintharyi Region), and in Taunggyi (Shan State). The MRCs are supported by the International Organization for Migration (IOM) in Yangon (Yangon Region), Mawlamyein (Mon State), Hpa-An (Kayin State), Magway (Magway Region), Pathein (Ayeyarwady Region), Sittwe (Rakhine State), and Hakha (Chin State). The MRC in Keng Tung in Shan State is supported by the ILO, but is run by the Mawk Kon Local Development Organization, not the
Migrant Worker Division. A final MRC is supported by both the ILO and the Mawk Kon Local Development organization in Tachilek in Shan State. The MRCs promote their services through meetings with the General Administration Department (GAD) and with other line departments, such as the Immigration Department, and with the police and through visits to employers. At these meetings, the MRCs explain their services and provide information about safe migration and migrant rights. However, these meetings do not involve migrants themselves; 1,251 potential and returned migrant workers accessed the ILO-supported MRCs in 2017 in Mandalay, Myingyan, Kyaukse, Meiktila, and Dawei; 1,284 potential and returned migrant workers accessed the Mawk Kon-managed MRC in Shan State.

The 12 MRCs overseen by the Migrant Worker Division are located inside LEOs,

Table 3.1

\section{Migrant Resource Centers}

\begin{tabular}{|c|c|c|}
\hline MRC & State/Region & Support \\
\hline Mandalay & Mandalay Region & ILO \\
\hline Meiktila & Mandalay Region & ILO \\
\hline Myingyan & Mandalay Region & ILO \\
\hline Kyaukse & Mandalay Region & ILO \\
\hline Dawei & Tanintharyi Region & ILO \\
\hline Taunggyi & Shan State & ILO \\
\hline Yangon & Yangon Region & IOM \\
\hline Mawlamyine & Mon State & IOM \\
\hline Hpa-An & Kayin State & IOM \\
\hline Magway & Magway Region & IOM \\
\hline Pathein & Ayeyarwady Region & IOM \\
\hline Sittwe & Rakhine State & IOM \\
\hline Hakha & Chin State & IOM \\
\hline Keng Tung & Shan State & ILO and Mawk Kon Local Development Organization \\
\hline Tachilek & Shan State & ILO and Mawk Kon Local Development Organization \\
\hline
\end{tabular}


which are managed by the Department of Labor. LEOs are primarily responsible for providing employment services, and they issue overseas jobseeker registration cards to people interested in working outside of Myanmar; obtaining such registration is a prerequisite of migrating abroad for work. LEOs send daily totals of overseas jobseeker registrations to the Migrant Worker Division and the Kayin State Department of Labor Office. Although LEOs are supposed to focus only on job matching, they provide support in many other areas related to labor, including by staffing MRCs. Labor officers at these LEOs have been trained by the ILO to deliver support services for migrants in addition to their LEO tasks. Only the MRC in Yangon has a dedicated staff member who is physically located at the LEO but is not LEO staff. The IOM finances this position.

Fifteen state and region Department of Labor offices assist with the management of international migration at the local level and oversee the activities of the LEOs. They also coordinate information about international migration, assist with the investigation of grievances related to international migration, and assist with the management of the MRCs. The MRCs send weekly and monthly reports to the offices about how many people are issued overseas jobseeker registration cards and how many people ask for information about the migration process.

The Department of Labor provides several other specialized services to migrants, including those provided in coordination with other agencies.

- The Migrant Worker Division and the Skills Development Division (another division of the Department of Labor that works on issues related to reskilling and upskilling) operate pre-departure training centers in North Dagon Township in
Yangon and Mandalay. The Migrant Worker Division provides guidelines on the curriculum and is informed when workers want to attend the predeparture orientation. The Skills Development Division provides the tutors for the training courses and support for curriculum development.

- An office of a section under the Migrant Worker Division in North Dagon Township in Yangon issues Overseas Worker Identification Cards (OWICs), ID cards that are issued to all migrants working overseas. The Department of Labor manages the data collected when issuing the OWICs. Online Appendix 5 includes additional information about the OWICs.

- OWICs are also issued at the Migrant Worker Office in Myawaddy in Kayin State on the border with Thailand. This office includes officers from the Department of Labor and the Immigration Department who oversee issuance of the OWICs and a brief predeparture training for migrant workers, right before they cross the border. Officers from the LEO offices in Kayin State take turns helping to issue the OWICs.

- In Myawaddy, at the border with Thailand, there is a coordination group that includes representatives from the Immigration Department, the Special Police, the Customs Office, the Passport Office, and the Department of Labor.

- The DepartmentofLabor, the Immigration Department, and the Special Branch oversaw the issuance of Certificates of Identity $(\mathrm{Cl})$ to undocumented Myanmar migrants in Thailand. There were two $\mathrm{Cl}$ offices in Mahachai (Samut Sakhon Province), two in Mueang Samut Prakan (Samut Prakan Province), one in Mae Sot (Tak Province), one in Mae Sai 
(Chiang Rai Province), one in Ranong (Ranong Province), one in Chiang Mai (Chiang Mai Province), one in Nakhon Sawan (Nakhon Sawan Province), one in Songkhla (Songkhla Province), and two mobile offices. The process of issuing Cls finished on July 30th, 2018.

Several ministries and agencies outside of MOLIP are important implementers of migration policy. The Ministry of Home Affairs created the Anti-Trafficking in Persons Division (ATIPD), which has 3 subdivisionoffices that run 18 AntiTrafficking Task Forces (ATTFs) in cities and at border crossings, and 3 child protection task forces (ILO 2017). The ATIPD also has a 24-hour hotline to report potential cases of human trafficking (ILO 2016a). The Ministry of Home Affairs also manages 15 Passport Offices in each state and region of Myanmar. ${ }^{4}$ The Department of Immigration officials are stationed at these offices as well. The office issue 8 types of passports, including the work passport (PJ) that migrants must have to migrate abroad. Online Appendix 6 provides additional details about the types of passports and the process for obtaining a passport. The Ministry of Foreign Affairs provides support to migrant workers abroad through its embassies and consulates. The Border Guard Police is in charge of border security.

An inter-ministerial committee plays a key role in managing overseas employment. The Education, Health, and Human Resources Development Committee is responsible for approving all overseas employment requests after review by the
Migrant Worker Division. The Committee is a subcabinet body chaired by the Union Vice President (1). ${ }^{5}$ Additional information on the Education, Health, and Human Resources Development Committee is provided throughout the chapter.

The private sector is heavily involved in the recruitment of migrant workers for overseas employment. The Myanmar Overseas Employment Agencies Federation (MOEAF), which was founded in 2013, is the coordinating body for private recruitment agencies recruiting workers for employment abroad, known as overseas employment agencies in Myanmar. Nearly all licensed agencies are members. MOEAF has offices in Yangon and Bangkok, and had an office in Kuala Lumpur that was closed in 2015 (ILO 2016a). MOEAF works with both NGOs and the government on the development and implementation of policies for the recruitment of migrant workers. MOEAF is also involved in coordinating the MOU governing migration to Thailand, the inspection of employers abroad, predeparture training, resolving complaints made by migrant workers, and facilitating the repatriation of migrant workers.

Many CSOs, NGOs, and international development agencies play an important role in the migration process in Myanmar These groups provide technical assistance to policy makers on the formulation of migration policy, and they deliver services directly to migrants and their families. The activities of these groups are described throughout the chapter.

\footnotetext{
4 The Passport Office in Yangon can issue passports to people from all states and regions of Myanmar.

5 Members of the Committee are the Union Minister for Information; the Permanent Secretary of the Ministry of Religious and Cultural Affairs; the Permanent Secretary of the Ministry of Transport and Communications; the Permanent Secretary of the Ministry of Natural Resources and Environmental Conservation; the Permanent Secretary of the Ministry of Electricity and Energy; the Permanent Secretary of the Ministry of Labor, Immigration, and Population; the Permanent Secretary of the Ministry of Industry; the Permanent Secretary of the Ministry of Commerce; the Permanent Secretary of the Ministry of Planning, Finance, and Industry; and the Permanent Secretary of the Ministry of Social Welfare, Relief, and Resettlement (Sein and Farrelly 2016). The Permanent Secretary of the Ministry of Education and the Permanent Secretary of the Ministry of Health are Secretary and Joint Secretary, respectively.
} 


\section{Areas for improvement and potential gaps}

In recent years, Myanmar has developed an institutional framework for managing international migration that includes a division of the Department of Labor devoted exclusively to issues of internationalmigration and MRCs that seek to support international migrants. However, the institutions responsible for managing international migration face human resource constraints. In many cases, agencies are operating with fewer staff members than they are permitted. The Migrant Worker Division is permitted to hire 147 staffers, but currently has 62. Despite their mission to support (domestic) job matching, the LEOs perform multiple functions, including in some cases functions related to international migration. At the Myawaddy LEO, for instance, LEO officers assist with the issuance of OWICs at the Migrant Worker Office, and deal with many complaints related to informal labor brokers.

A recent ILO report highlights several breakdowns in the coordination of Myanmar's migration system (ILO 2017). The OESC meets infrequently, and engagement across the subcommittees is limited. This suggests that coordination itself may be limited at the higher ministerial levels. While the NPA process has offered some opportunities for nongovernment actors to provide input about migration policy, there are few other ways for them and for migrants themselves to contribute. For instance, migrants have no representation on the OESC. This issue extends beyond the public sector to the Myanmar Overseas Employment Agencies Federation, which does not include any migrant representatives on a committee formed to rank the performance of recruitment agencies that have signed a Code of Conduct.
The Migrant Worker Division conducts the day-to-day business of migration management and has developed significant expertise in this area. However, the decisions about migration are typically made at higher levels within MOLIP (ILO 2017). Additionally, all requests for employment overseas must be approved by the Education, Health, and Human Resources Development Committee, a subcabinet-level committee chaired by Union Vice President (1) and composed primarily of Permanent Secretaries (very senior officials). This high level of oversight for individual employment requests can lengthen the regular migration process (the Committee only meets every two weeks, which means that a request can sit for up to 13 days before being reviewed).

Strengthening MRCs in particular could improve the functioning of the migration management system. The MRCs lack financial and human resources. They share the budget allocation for LEOs, and have received in-kind support from the ILO and IOM for chairs, computers, pamphlets, and other items. In most cases, MRC officers have all of the duties of a LEO officer but are also responsible for MRC-related tasks. Trainings have been provided to some, but not all LEO officers who undertake these tasks. The services that the MRCs provide are currently limited to provision of information about the migration process and licensed recruitment agencies and some assistance with dispute settlement. The broader services that MRCs could providesuch as helping migrants reintegrate upon return to Myanmar-are not currently being offered. The use of MRC services has been low so far, suggesting that MRCs are not yet recognized as providers of valuable services. Finally, there is no MRC in Myawaddy at the border with Thailand, a popular crossing point for migrants. 


\section{Deployment restrictions and requirements}

Myanmar's laws and regulations impose several restrictions and requirements to protect migrants from adverse employment experiences. These include deployment restrictions, which prevent migrants from migrating to certain places or migrating to perform certain tasks. They also include deployment requirements, which ensure a minimum standard of employment abroad.

Myanmar imposes restrictions on the types of migrants who can migrate and where those migrants can go for employment abroad.

- Destination country restrictions. Myanmar only permits workers to migrate to Thailand, Malaysia, Korea, Japan, Singapore, the United Arab Emirates, Qatar, and Jordan. Responding to a political controversy, Myanmar banned workers from migrating to Malaysia between late 2016 and February $7^{\text {th }}, 2018 .{ }^{6}$

- Occupation restrictions. Migrants had been prohibited from migrating to work abroad as domestic workers, but the rules have changed over time (NapierMoore 2017). Migration of domestic workers to Singapore and Hong Kong SAR, China, was permitted in 2013, but then banned in September 2014. Even then, however, domestic workers who had previously migrated to Singapore were allowed to migrate again. ${ }^{7}$ Migration of domestic workers to Hong Kong SAR, China; Macau SAR, China; Singapore; and Thailand is no longer prohibited. Migrants were previously prohibited from working in the fisheries sector, but are now permitted to do so in Thailand and Korea.

- Gender restrictions. Prior to 2009, women were not allowed to register for overseas employment (NapierMoore 2017). Currently, demand letters requesting female employees to work in the Malaysian state of Johor, which borders Singapore, must include at least 10 women, and the worksite must be inspected by the labor attaché, a representative from the Myanmar Overseas Employment Agencies Federation, and a representative of the Myanmar recruitment agency. Recruitment agencies must generally ensure that women migrating abroad for work will work in a group of at least five women at the worksite and, preferably, migrate with a group of that size (Napier-Moore 2017). Because of the high prevalence of women working in domestic work, the occupation restrictions related to domestic workers are particularly binding for female migrant workers.

- Employer restrictions. The Migrant Worker Division posts a list of employers, employer representatives, and recruitment agencies in Thailand that are blacklisted for not protecting workers' rights. As of the end of June 2019 this list included 63 employers, 18 employer representatives, and 9 recruitment agencies. Labor attachés in Thailand and Malaysia inspect employers and workplaces.

There are also several requirements that migrants and recruitment agencies in Myanmar and abroad must meet before

6 Htwe, Zaw Zaw. 2018. "Myanmar Lifts Worker Ban to Malaysia." The Myanmar Times, January 11, 2018. https://www.mmtimes.com/ news/myanmar-lifts-worker-ban-malaysia.html.

7 Before the Migrant Worker Departure Counter was eliminated, migrant workers needed to provide a job passport (PJ) at the Migrant Worker Departure Counter to prove that they had been to Singapore previously (including their expired passport if they had obtained a new one). 
a migrant takes up employment abroad. These requirements relate to the demand letters that specify an employer's labor needs, the terms and conditions of employment included in labor contracts, and the procedural steps a migrant must take in order to legally cross the border for employment.

The demand letters from overseas employers must be vetted by the Government of Myanmar. This vetting process is intended to ensure that employment opportunities abroad are real and permissible, align with Myanmar's migration restrictions, and involve decent work at decent wages under decent conditions. The procedures for vetting demand letters received under the Myanmar-Thailand MOU are described as an example. ${ }^{8}$

- Myanmar's labor attaché in Thailand must first review demand letters transmitted from Thai employers requesting migrant workers from Myanmar. If the employer is known to the labor attaché, the attaché will contact the employer's human resources department to verify the details of the demand letter. This process takes between 2 and 3 days. If the employer is not known to the labor attaché, the attaché visits the employer. In this case, the length of the process depends on the availability of the 2 labor attachés in Thailand who have additional responsibilities, such as overseeing the Certificate of Identify process and attending meetings in Myanmar.

- Once verified by the labor attaché, the Department of Labor in Myanmar reviews the demand letter. In most cases, the Migrant Worker Division also reviews the demand letter, looking at wages (such as whether the wages are consistent with Thailand's minimum wage), recruitment fees, the location of work, and other factors. Sensitive cases may be sent to the Director General or to the Minister for review.

- Finally, the Department of Labor sends verified demand letters to the Education, Health, and Human Resources Development Committee for approval. The Committee's review involves officers of the Migrant Worker Division presenting the demand letters for consideration of wages, location of work, worker protections, recruitment fees, and the total number of demand letters. The Committee meets each Tuesday and demand letters must be transmitted to the Committee by the preceding Thursday for inclusion in the next week's meeting. Approval typically takes 2 or 3 days. The Department of Labor informs recruitment agencies of approval by e-mail. The agencies generally know when their demand letter will be considered by the Committee and so are ready for approval when it comes. Overall, approval of the demand letter takes about 3 weeks.

The process for reviewing demand letters for countries other than Thailand is largely the same. ${ }^{9}$ The primary difference in the review process is that for countries without labor attachés, the embassy in the destination country must assign regular staff to review the demand letter and the employer. This can require additional time since, unlike labor attachés, these staff members are not just working on migrationrelated issues.

8 Additional detail on this process is available in Online Appendix 4.

9 The exception is Korea. The process for migrating to Korea is determined by the MOU establishing Myanmar's participation in Korea's Employment Permit System (EPS). See Error! Reference source not found. for additional details. 
Myanmar imposes requirements on employment contracts for international migrants. Recruitment agencies must submit employment requests, including information about working conditions, salary, working hours, and leave to the Education, Health, and Human Resources Development Committee for approval. These requests also include the employment contract, so that contract terms can be verified and to ensure that the contract reflects the demand letter. Agencies recruiting migrants to work in Thailand must submit employment requests that list the number of employees, the type of job, the place of work, age, working hours, salary, qualifications, holidays, food and accommodations, and other details. The employment contract itself must include the validity of the contract, holidays, leave, benefits, salary, and health care and employee welfare programs. The Myanmar-Thailand MOU states that the employment contract must be provided in Myanmar language, Thai, and English. For countries other than Thailand, there are no specific requirements about what must be included in the employment contract. Employment contracts for working in Malaysia allow salary deductions of 50 ringgit for accommodations, and in the past, employers took deductions to cover levies imposed on the employment of migrant workers. The Myanmar Overseas Employment Agencies Federation has created a Code of Conduct for overseas employment agencies that includes a recommendation that the agencies ensure that employment contracts are comprehensive about working and living conditions.

Prior to migrating abroad for work, migrants must comply with a series of departure requirements. While the requirements for migrants to depart formally from Myanmar vary by the country of destination, migrants generally must obtain an overseas jobseeker registration card by registering at a Labor Exchange Office ${ }^{10}$; a PJ (job) passport from a Passport Office ${ }^{11}$; a demand letter approved by the Education, Health, and Human Resources Development Committee; and a predeparture training certificate. Migrants are also required to obtain the OWIC, which has the migrant's passport number, the name and address of the recruitment agency, and the name of the factory where they are working. Migrants can also use the OWIC to contact the Myanmar Embassy in case of need. Online Appendix 5 provides details about the process for obtaining an OWIC. Recruitment agencies help migrants fulfill all of these requirements. Table 3.2 summarizes the deployment requirements for Myanmar migrants by country of destination. Online Appendix 4 summarizes the process of migrating from Myanmar to Thailand, Malaysia, Korea, and countries without labor attachés.

\section{Areas for improvement and potential gaps}

Myanmar has a range of policies in place that are designed to protect migrants from adverse employment experiences abroad. However, some of these policies may be less effective or have unintended adverse consequences. First, Myanmar's restrictions on destination countries seem to have limited effectiveness. Despite there being no formal pathway for migration to countries like China, migration outside of the permitted countries is common. China, for instance, has become a prominent destination for Myanmar migrants: the 2014 Population and Housing Census found that China was the third most 
Table 3.2

Deployment requirements for Myanmar migrants by country of destination

\begin{tabular}{l|c|c|c|}
\multicolumn{1}{c|}{ Requirement } & Thailand & Malaysia & No labor attaché \\
\hline Overseas jobseeker registration card & $X$ & $X$ & $X$ \\
\hline Job Passport (PJ) & $X$ & $X$ & $X$ \\
\hline Approved demand letter & $X$ & $X$ & $X$ \\
\hline Predeparture training certificate & - & $X$ & $X$ \\
\hline Overseas Worker Identification Card (OWIC) & $X$ & $X$ & $X$ \\
\hline "-" indicates not required. \\
$\begin{array}{l}\text { Note: Deployment requirements are not included for Korea since these are set by the EPS system. } \\
\text { Source: Authors. }\end{array}$
\end{tabular}

frequent destination country. Restrictions on Myanmar people migrating as domestic workers also appear to have limited effectiveness. The imposition of the ban and its status are not clear, and the ban was poorly communicated; the migration of domestic workers does not seem to have ceased (Napier-Moore 2017).

Second, migration restrictions can have unintended consequences. These restrictions can encourage informal migration, which exposes female migrants (who are more likely to work as domestic workers) in particular, to a greater probability of exploitation, and it means that fewer services are available to them. Myanmar's ban on migration for domestic work has led to an increased use of illegal brokers and to informal payments that facilitate the exit from Myanmar (NapierMoore 2017). Although the number of women migrating for domestic work through regular channels has decreased, the ban on domestic work appears to be driving women to use irregular channels to migrate (ILO 2015c; Harkins, Lindgren, and Suravoranon 2017; Napier-Moore 2017). A survey of Myanmar migrants in Thailand and Malaysia in 2016 found that domestic workers made up 11 percent and 9 percent of migrants surveyed in the two countries, respectively (Harkins, Lindgren, and Suravoranon 2017). Eighty-two percent of these migrant domestic workers were women. Additionally, evidence from other countries suggests that these restrictions may ultimately have a negative effect on Myanmar's labor market. A study of Indonesia's moratorium on the migration of female domestic workers to Malaysia and Saudi Arabia shows several negative effects (Makovec et al. 2018). The moratorium on migration to Saudi Arabia was found to have led to: (1) a decline in household per capita consumption expenditure of between 3 and 4 percent per year in districts with high migration in the four years after the moratorium; and (2) an increase in the poverty rate of between 2 and 3 percentage points per year in the 3 years after the ban. Additionally, the domestic work bans in Malaysia and Saudi Arabia were found to have led to a decline in female employment and labor force participation of up to 4 percentage points.

Migrant workers must obtain many documents and go through many procedures in order to migrate formally. For example, the process for reviewing demand letters is cumbersome: In addition to a review by the labor attaché in the case of Thailand and Malaysia and by the Myanmar Embassy in the case of countries without labor attachés, the demand letter must be verified by the Department of Labor and then by the 
high-level Education, Health, and Human Resources Development Committee. This process takes approximately 3 weeks. While Myanmar cannot control some of the procedures that are required by destination countries, there are multiple requirements from the Myanmar government as well. The overseas jobseeker registration card issued by LEOs, in particular, is a requirement that may be redundant since a potential migrant worker also obtains a passport and the OWIC. The NRC, which potential migrants may lack, is a minimum requirement for regular international migration, and without it, a jobseeker cannot use official jobseeking channels for employment abroad. Physical documents are verified at many different steps of the migration process, often to ensure that documents have not been forged. Migrants must enlist the assistance of a recruitment agency to help them navigate these deployment requirements.

\section{Training}

Training programs improve the employability of jobseekers by equipping them with the knowledge and skills they need to find a job. For migrants looking for jobs abroad, training provided prior to their departure includes sessions on the migration process and provides other relevant information such as how to send money back home. In fact, most of the training for international migrants tends to be awareness raising and soft skills training.

International migrants are often unaware of the requirements for legal migration. For instance, one recent study of 625 potential migrants in Myanmar found that many (70 percent) were aware that a passport and visa were necessary for legal migration, but fewer knew that a job offer (27 percent)
The information management system used for managing demand letters is limited and largely manual. Information in the demand letters must be entered into the system manually; that is, recruitment agencies are not able to submit the demand letters online. Entering information manually is time consuming, and so not all information collected in the demand letters is included in the system. Demand letters are also reviewed manually. When many demand letters are received at one time, reviews can be delayed. A database to store the demand letters is reportedly being developed, but a lot of the information is still being stored physically. Additionally, approval of demand letters is issued on paper by the Education, Health, and Human Resources Development Committee, and that step also takes time. Migrant Worker Division staff currently inform overseas employment agencies of approvals inperson or via e-mail.

and a work permit (19 percent) were also necessary (ILO 2015d). Only 9 percent of the potential migrants were aware of the cap on recruitment fees, while nearly 20 percent were unaware of the articles that should be included in employment contracts.

The Department of Labor offers a predeparture orientation course free of charge to anyone considering migration, as long as they have an NRC, at its training centers in North Dagon in Yangon and in Mandalay. This orientation training is an outgrowth of a training course originally developed for migrants to Malaysia. The Myanmar Overseas Employment Agencies Federation (MOEAF) helped provide the training, which was given in North Dagon 
between 2003 and 2008, stopped in 2009, and begun again in 2010, this time with MOLIP. MOLIP then took over delivery of the training and expanded it to destination countries beyond Malaysia. At the end of 2016, the predeparture course was established in Mandalay, which extended the geographic reach of the training. The training is mandatory (migrants must receive the training in order to obtain an OWIC), ${ }^{12}$ except for migrants to Thailand who receive a brief training at the border with Thailand, and for migrants to Korea who are subject to the Myanmar-Korea MOU and receive a separate orientation course (though this training is done in North Dagon and Mandalay, as well). Although anyone can attend the predeparture course, licensed recruitment agencies typically organize groups of migrants to attend the course, including paying the costs associated with attendance. The training lasts 3 days for 6 hours each day. There are four trainers at the North Dagon training center and five in Mandalay. The orientation course is conducted by these trainers, as well as by antitrafficking and immigration officers. The ILO provides training of the trainers courses to trainers at the training centers, as well as to labor officials and the MOEAF.

The orientation curriculum was developed by the Migrant Worker Division with input from labor attachés and the Skills Development Division, and support from the International Organization for Migration $(\mathrm{IOM})$, based in part on the original training developed for Malaysia. The Migrant Worker Division also provides migration guidelines for the trainers to explain. The curriculum is standardized, although some customization is done for modules on the culture of the destination country, particularly when a batch of trainees is migrating to a single country (this can occur when recruitmentagencies organize a group of migrants to a particular country to attend the training). While the training office tries to group migrants based on the country of destination, this is not always possible. The orientation includes information about employment, valid employment contracts, cultural awareness, occupational safety and health, employment law, rights and obligations of workers and employers, and contact information for the Myanmar embassy and labor attachés (Oo 2017). The orientation is delivered using PowerPoint presentations, videos, and posters with information like the list of licensed recruitment agencies. Pamphlets created by the IOM and ILO in partnership with MOLIP are provided. Return migrants in attendance at the orientation may be asked to share their experiences. Attendees receive a certificate of completion, which is necessary for migrants to obtain the OWIC.

There are several differences between the North Dagon and Mandalay predeparture orientations. The maximum capacity of each Mandalay predeparture orientation is 200 people, while in North Dagon, the capacity is 300 people. Two trainings are conducted each week in North Dagon. Fewer training sessions are conducted in Mandalay (in 2017, a total of 10 orientations were given) and fewer migrants receive the training than in Yangon. This reflects in part the lower demand in Mandalay, as there are few recruitment agencies there and most workers depart for Thailand and Malaysia via Yangon. Most attendees of the Mandalay orientation are from rural parts of Mandalay Region and tend to migrate to Japan and Korea, while attendees of the Yangon orientation are primarily migrants to Thailand and Malaysia.

Although migrants to Thailand do not attend the formal 3-day predeparture

12 This requirement does not appear in the Law Relating to Overseas Employment 
orientation, they receive information at two stages in the migration process. First, the Department of Labor mandates that migrants to Thailand attend a ceremony for the signing of their employment contract. This signing ceremony is held either in Yangon in North Dagon or in Hpa-An at the Kayin State Department of Labor office. Signing ceremonies were first held in Hpa-An in 2017 primarily to accommodate people from Mon State and Kayin State and "U-turn" migrant workers returning from Thailand with plans to re-migrate. ${ }^{13}$ However, the decision of where to attend the signing ceremony is made by the Myanmar overseas recruitment agencies, who decide based on location, availability of appointments, and accessibility for the Thai recruitment agencies. Prior to signing the employment contract, the Myanmar licensed overseas recruitment agency explains the location of the job and the name of the employer. The Head Officer of the state or region Department of Labor office explains the contract to make sure that the migrant understands its contents and provides Dos and Don'ts for living in Thailand. This Dos and Don'ts instruction includes guidance on the rules and regulations in Thailand, such as restrictions on changing jobs without an employer's permission, how to use money wisely, and how to avoid trouble. The instruction also includes information about social security benefits available to workers in Thailand. Second, just prior to crossing the border to Thailand, labor officers and immigration officers provide additional pre-departure information to migrant workers at the Migrant Worker Office in Myawaddy. A senior labor officer from Yangon or Nay Pyi Taw typically delivers the training, along with a supporting officer from a LEO in Kayin State. This training includes practical information about living in Thailand, storing passports securely, and contact numbers in Thailand such as that of the labor attaché and of the recruitment agency, which the migrants should already have. The training is conducted using posters.

As part of the MOU with Thailand, the Thai Department of Employment and Thai recruitment agencies provide a 30-minute orientation training to migrant workers just after they cross the border in Myawaddy. The training is designed to ensure that workers are aware of Thai rules and regulations. The IOM is currently working with the Thai Department of Employment to provide a curriculum for the training based on a handbook the IOM had already developed. In Mae Sot, the IOM also raises awareness about safe migration, human trafficking, and access to benefits for migrants in Thailand.

Predeparture orientation is also provided through local government channels. The state and region Department of Labor offices and the LEOs offer migration awareness programs. For instance, in 2017, the Magway Region Department of Labor office held 38 awareness-raising events at the township level, in coordination with the General Administration Department (GAD) and with village heads about laws related to internal and international migration. These events used a PowerPoint presentation, but did not involve handouts.

CSOs, NGOs, and international development agencies also provide predeparture orientation. Through its TRIANGLE program, the ILO has supported safe migration and predeparture courses, including predeparture materials in minority languages for migrants to Thailand; safe migration training for farmers and agricultural workers; and the training of trainers from the Department of Labor and the Myanmar Overseas Employment

13 The signing ceremony is held in Hpa-An rather than in Myawaddy at the border because the region Department of Labor office is in Hpa-An. 
Agencies Federation. The IOM, in partnership with local CSOs, supports premigration outreach on making migration a livelihood strategy, and it provides information on safe migration through its Twe Let project in Mon State, Kayin State, Tanintharyi Region, Shan State, Chin State, Mandalay Region, and Magway Region. For instance, the Mon State Department of Labor office works with the IOM's Twe Let project to provide safe migration training. IOM requests the Head Officer or deputy Head Officer of the state office to deliver an awareness program, and they provide information about formal migration and the consequences of irregular migration. IOM's Migration as a Livelihood Diversification Strategy in the Delta (MILDAS) project provided information to individuals in Ayeyarwady Region who were considering migration and how to take more strategic migration decisions and actions. The information was provided through CSOs and faith-based organizations.

Smaller-scale initiatives to raise awareness about safe migration and human trafficking have been delivered in local areas throughout Myanmar. For instance, in Bago Region, Karuna Mission Social Solidarity (KMSS) has not only been involved in raising awareness about safe migration and human trafficking, they have also provided reintegration support for trafficking survivors. The Myanmar Baptist Convention has supported communitydriven development projects that include generating awareness on gender issues and what is involved in safe migration. In Kayin State, the Myanmar Migrant Monitoring Group attempts to raise awareness of the law among aspiring migrant workers.

Financial literacy training is not formally provided to migrants as part of the Department of Labor's predeparture orientation. However, IOM's Twe Let project provides financial literacy training to migrants, including lessons on saving money and productively using remittances. The IOM's MILDAS project provided financial literacy training in the Ayeyarwady Region, including on remittances management and investing financial resources.

There seem to be few links between skills training and the migration system in Myanmar. Only 22 percent of migrants surveyed after returning from migration abroad reported receiving skills training prior to departure, although this number is higher than for migrants from Cambodia, Lao PDR, and Vietnam (ILO and IOM 2017). Lack of available skills training courses is likely one of the main reasons for the lack of training. One exception is a training program for migrant workers in Mon and Kayin States that is run by the Education and Training Department of the Ministry of Border Affairs in cooperation with the Skills Development Division of the Department of Labor. The program is targeted to migrants who have worked in Thailand and wish to return to Myanmar. Training is provided in welding and sewing machine operation, and includes a certification component. There have been more than 3,000 participants in the program. Two meetings have been conducted with the ILO on recognizing the certification in Thailand. A pilot on the mutual recognition of masonry/bricklaying skills has also been considered (ILO 2018).

Private training centers at times provide training with the purpose of preparing workers for employment abroad (Milio, Garnizova, and Shkreli 2014). For example, one overseas employment agency runs a vocational skills training center that provides courses in electrical installation, air conditioning, welding, and plumbing. The agency contacts graduates of these courses if and when it receives a demand letter, typically from Singapore, looking for workers. Skills training was provided by recruitment agencies to domestic workers 


\section{A recent study found that about half of Myanmar migrants who had returned from abroad reported that they had completed skills training in the destination country as part of their employment}

migrating to Singapore before the ban on such migration (ILO 2016a). Some skillstraining programs for potential migrant workers have been created in partnership with CSOs, NGOs, and international development agencies. For instance, IOM's Twe Let project supports skillsdevelopment training for migrant workers as well as job-matching support.

A recent study found that about half of Myanmar migrants who had returned from abroad reported that they had completed skills training in the destination country as part of their employment (ILO and IOM 2017). This is significantly higher than the 22 percent who report receiving skills training prior to departure.

\section{Areas for improvement and potential gaps}

Myanmar's predeparture orientation is freely available, but it is not required for migrants to Thailand, the most popular migrant destination. In part, this may be a result of the already-high levels of informal migration to Thailand, and the difficulty of enforcing a requirement to obtain predeparture training, especially since the main training facilities are in Yangon and Mandalay. In place of formal predeparture orientation, migrants receive a brief "Dos and Don'ts" training at the border. Making predeparture orientation more geographically available through MRCs and LEOs could help expand access to knowledge about migration procedures, including migrants to Thailand and migrants not using formal migration channels. While the predeparture training facilities in Yangon and Mandalay reflect the fact that most (formal) international migrants depart from Yangon, the impact that predeparture orientation can have on an individual's decision to migrate is limited, since they are in Yangon or Mandalay often just before departure. Predeparture orientation programming in the Philippines offers several relevant practices for Myanmar (See International Spotlight 3 in Chapter 4.).

The skills training for international migrants is limited. In part, the lack of skills training results from the limited resources provided to MOLIP's six skills-training centers. As the centers mature, it will be important to create connections with the private sector to ensure that the training is informed by the needs of employers in countries demanding migrant workers from Myanmar (see International Spotlight 2 in Chapter 4).

Devoting more attention to the skills of migrant workers is important, because migrants' education levels are lower than those of migrants from other countries. Within Myanmar, migrants tend to be more educated than the working-age population, but this is not true outside of Myanmar. Only 5 percent of Myanmar migrants in Thailand had some intermediate education (that is, upper secondary or post-secondary, non-tertiary education), and only 2 percent 


\section{Educational composition of Myanmar workers in 2010}

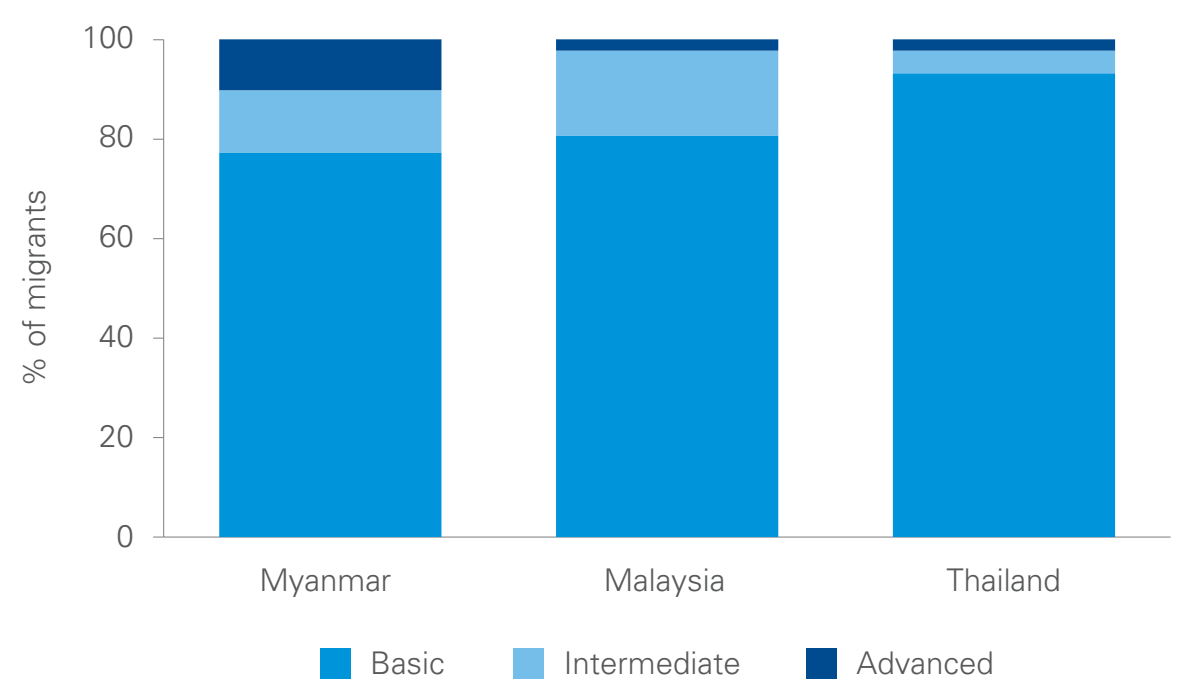

Notes: Basic denotes primary and lower secondary education; intermediate denotes upper secondary and post-secondary, non-tertiary education; and advanced denotes tertiary education. The Myanmar bar shows the educational composition of the labor force in Myanmar, while the Malaysia and Thailand bars show the educational composition of Myanmar migrants in those two countries.

Source: World Bank estimates using the Database on Immigrants in OECD and Non-OECD Countries and the ILMS Database.

had some tertiary education (Figure 3.2). Myanmar migrants to Malaysia were slightly better educated; 18 percent had intermediate education, and 2 percent had advanced education qualifications. A study of Myanmar migrants in Thailand found that the majority had received skills training at the destination, rather than before leaving Myanmar (Harkins, Lindgren, and Suravoranon 2017). Earlier data from 2000 suggests that Myanmar migrants have much lower skill levels relative to other ASEAN migrants in Thailand (Testaverde et al. 2017).

This relatively low level of skills limits the choice of destination for aspiring migrants and makes them less competitive. Aspiring international migrants with higher levels of education have more options in terms of destination. Migrants to Thailand, Malaysia, and China tend to be unskilled or semiskilled, while migrants to Korea, Japan, and Singapore tend to be skilled (ILO 2015c; World Bank and CESD 2018). In Thailand, stakeholders perceive Myanmar migrants to be low-skilled and willing to take whatever jobs are on offer (Harkins, Lindgren, and Suravoranon 2017). A 2018 survey of migrants in the agricultural sector in Thailand found that Myanmar migrants earned substantially less than migrants from Cambodia and Lao PDR (Harkins 2019).

There is little financial literacy training for migrants in Myanmar. The lack of financial literacy and access to affordable credit constrain the ability of returning migrants to invest their savings profitably. There is some evidence of returnees investing in land (mainly for cash crops) and setting up small-scale businesses such as trading, retail, hotels, and restaurants. However, these investments depend on the resourcefulness of the returnee and how well the family managed remittances received in the migrant's absence (Maharajan and Myint 2015; World Bank and CESD 2018). Given that only 52 percent of the population is financially literate, many migrants and migrant-sending families do 
not have the knowledge to save or invest remittances profitably (UNCDF 2017). For example, there are cases in the Southeast in which families spend rather than save remittances, so that return migrants were forced to look for jobs on their return instead of having the capital to start small businesses or purchase productive assets (World Bank 2018; World Bank and CESD 2018). In the Dry Zone and in the Southeast, returnees who were running small businesses felt that the lack of access to credit constrained their ability to expand. In fact, this lack of credit access is commonly cited by Myanmar businesses as an impediment to their growth. Financial literacy programs in other countries have improved financial awareness and knowledge, budgeting, and savings (Doi, McKenzie, and Zia 2014). (See International Spotlight 4 in Chapter 4.)

Remittances remain largely informal in Myanmar. The absence of competitive exchange rates and limited outlets for international settlements have historically made formal remittances unattractive in Myanmar (Kubo 2017). In an IOM survey of 5,027 Myanmar migrants in seven provinces of Thailand, 87 percent reported using unofficial channels to remit money. The lack of identity cards or bank accounts and the distance to urban centers were cited as barriers to using formal channels (IOM 2016a). Instead, migrants used informal channels-mostly brokers, relatives, or friends, or they carried the remittances themselves. Access to financial institutions in Myanmar remains limited, and informal hundi brokers remain popular among migrants (Ma 2017). Notably, these brokers sometimes use the formal financial system to transfer money within Myanmar (Kubo 2017). While research on why informal brokers remain popular is scant, a combination of limited access, high cost, and lack of trust of the financial system is likely responsible (Akee and Kapur 2017).
Several recent developments have made formal remittances more attractive, which suggests that financial education in conjunction with other activities may help shift remittances to formal channels (see International Spotlight 5 in Chapter 4). For example, banks have been permitted to establish operations overseas in several ASEAN countries; remittance-sending migrants are no longer taxed both abroad and in Myanmar; and the exchange rate has been liberalized (Hall 2012; Ma 2017). The Ministry of Foreign Affairs announced in 2017 that an MOU had been reached for money transfer services between the Myanmar Economic Bank and Krung Thai Bank, which would allow migrant workers to transfer money across the border. And in early 2019, the Singaporean telecommunications company Singtel announced a partnership with the United Nation's Capital Development Fund to provide remittance services to Myanmar migrants in Singapore through its mobile payments service Dash. New digital tools also allow migrants to evaluate remittance costs in real time. SaverAsia allows migrants in ASEAN countries to compare up-to-date remittance costs across moneytransfer services for different remittance corridors, and it links migrants to financial services and provides information on financial education courses and support in origin and destination countries (ILO 2019).

Training provided to migrants once they arrive in the destination where they will work can help them adjust to their new environment and provide them with resources in case they need assistance (see International Spotlight 6 in Chapter 4). However, this postarrival training is limited. Myanmar might consider using labor attachés to provide some orientation to migrant workers when they arrive in their destination country. 


\section{Labor market information}

LEOs generally do not have information about employment opportunities abroad. Instead, overseas employment agencies identify both opportunities abroad and the workers to fill those opportunities. Officers from the MRCs, who in most cases are LEO officers, do provide jobseekers interested in working overseas with a list of licensed overseas employment agencies. The MRCs try to narrow the list of several hundred licensed agencies by identifying those agencies that send the most migrants to the destination country of interest or those based on personal knowledge of reputable agencies. An ILOsupported ranking system for the overseas employment agencies being created by the Myanmar Overseas Employment Agencies Federation's is designed to help the MRCs inform potential migrants of the best agencies to choose. Formerly, overseas employment agencies were required to wait until the Education, Health, and Human Resources Development Committee approved an employment request before they could advertise their job openings, although this requirement has been removed. Overseas employment agencies report the list of hired migrant workers to the LEOs.

The state and region Department of Labor offices host job fairs to introduce jobseekers to international migration and overseas employment agencies. For instance, job fairs were held in 2017 and early 2018 in Magway and Pakokku in the Magway Region. All of the licensed overseas employment agencies were invited to explain to villagers the services they provide, the migration process, and the cost. Fifteen agencies attended the fairs. As there was concern that villagers did not understand the concept of a job fair, job-matching services were not provided. In 2018, the region Department of Labor office in Mawlamyine in Mon State hosted a job fair, which was financed by SwissContact. The job fair was attended by 7 overseas employment agencies and 16 employers, 3 or 4 of which were from Yangon, and the others (mostly local firms) worked in construction, hotel services, and rubber. During the job fair, about 300 people enquired about the overseas employment agencies.

Informationaboutmigrating for employment abroad is available from several other sources. MRCs offer information to people visiting the LEOs about the formal migration process and safe migration, and they provide a list of licensed overseas employment agencies to potential migrants. MOLIP also posts some safe migration information on its website. ${ }^{14}$ This includes guides on how to migrate legally to Thailand and Malaysia, how to apply for a passport, contact information for the MRCs and the Complaints Mechanism Centers, tips on working in Malaysia, and a guide for migrant domestic workers produced by the Ministry of Manpower in Singapore. Additionally, the Passport Offices provide information on safe migration.

Several projects implemented by CSOs, NGOs, and international development agencies disseminate labor market information. IOM X, sponsored by IOM and the United States Agency for International Development (USAID), is a regional campaign to thwart human trafficking and exploitation. IOM $X$ has sponsored a series of videos in Myanmar that provide information about migration procedures and

14 See, for example, https://www.mol.gov.mm/mm/safe-migration-8 (last accessed August 23, 2018). 
services through the stories of migrants. IOM's Miss Migration Facebook page includes Myanmar language information about migration and a chat bot to answer queries and provide additional information. BBC Media Action provides less formal training directed to migrants via national Myanmar language radio broadcasts on the state broadcaster Myanmar Alin and online media about migration and remittances. BBC Media Action's Yay Kyi Yar: Making the Most of Migration and Money is a national radio show on the state broadcaster Myanmar Alin that provides information on migration and finance. The ILO has translated its financial literacy handbook into the Myanmar language. CSOs have trained local community leaders to provide safe migration training and information, and they have helped create community peer support networks for information sharing (ILO 2018).

The ISSARA Institute, an NGO that works to reduce human trafficking and forced labor through technology, has developed an Android app called Golden Dreams, which is a Myanmar-language smartphone app for learning and exchanging information, reviews, ratings, comments, and advice about employers, recruitment agencies, and service providers in migrant source and destination countries. The app is designed primarily for workers looking for jobs abroad and their parents. Golden Dreams' main features are: (1) alerts and notifications, such as about changes in regulations; (2) news related to migrant workers; (3) a guide on workers' rights, including information about how to live and work in Thailand (providing information about other destination countries is being considered); (4) a polling feature; (5) searchable information on all licensed overseas employment agencies recruiting to Thailand and their local representatives, along with the ability to see and provide user-generated reviews; (6) searchable information on employers in Thailand; and (7) information on service providers, such as those who provide training and job matching. The ISSARA Institute would like to include information on approved demand letters, and advertise the app at LEOs and MRCs. The app has more than 10,000 users. One of the app's key challenges is that migrants change SIM cards frequently; with every new sim card, the app must be downloaded again. This also makes staying in touch with migrants difficult.

Recruitment agencies, labor brokers, and informal contacts are also sources of information about the labor market. Friends and relatives frequently relay information about job opportunities to potential migrants. Brokers at the village level may have connections with recruitment agencies, and be able to provide potential migrants with information about working conditions and recruitment costs (Verité 2019). Recruitment agencies also advertise job openings on Facebook.

\section{Areas for improvement and potential gaps}

Awareness about the migration process and what to expect at the destination is generally limited. A survey of Myanmar migrants in Thailand and Malaysia found that only 11 percent of respondents had obtained information prior to their departure $(9$ percent in Thailand and 15 percent in Malaysia) (Harkins, Lindgren, and Suravoranon 2017). This figure was higher for men than women (14 percent vs. 7 percent). A different survey of aspiring international migrants in three states and regions found that 55 percent knew about wages and 40 percent knew about working hours (ILO 2015c). CSO representatives in Myawaddy note that workers are not fully aware of their rights and responsibilities (World Bank and CESD 2018). For instance, there are cases in which workers change 
employers without informing the Labor Department in Thailand, and they lost their employment status, because documenting a change in employer is required. Awareness is generally higher among those migrating from areas with a longer history of migration, although evidence of this is limited. For example, international migrants from the border states of Shan, Mon, Kayin, and Tanintharyi have more information on destination employment conditions and living arrangements relative to those from other states and regions (ILO 2015c; World Bank and CESD 2018). In fact, 44 percent of aspiring migrants surveyed from Mandalay were unaware of problems they might encounter when migrating, such as unfair wages and long working hours, whereas only 11-13 percent of aspiring migrants from Shan and Tanintharyi had the same lack of awareness (ILO 2015c).

There are gaps in the labor market information available to international migrants. Information on job vacancies abroad is not available to migrant workers, so they rely on family and friends, informal recruitment agents, and licensed recruitment agencies to learn about job postings. LEOs donotadvertise international jobs, and they do not encourage overseas employment agencies to post vacancies at their offices. International job openings are not available on the public job-search website MyanmarJob.gov.mm/ (see International Spotlight 8 in Chapter 4), and information about overseas employment agencies is limited.

Because overseas employment agencies play such a key role in the migration process, the selection of a recruitment agency is one of the most important decisions a migrant makes. The list of recruitment agencies is published on the Department of Labor's website and is posted in the training center in North Dagon, Yangon. Beyond the names of the agencies, however, there is scant information on the agencies available to migrants. Although the Department of Labor publishes a list of blacklisted employers and overseas employment agencies, the complaints made against agencies do not seem to be made public. The current efforts of the Myanmar Overseas Employment Agencies Federation to create a ranking system for the agencies would help migrants make informed choices (see the section on the Code of Conduct below). Funneling this information to MRCs might give these centers a more active and practical role in arming potential migrants with practical information.

Information about deployment restrictions and requirements is lacking. Migrants may be unaware of the official policies, especially when they change. For instance, there was significant confusion when the ban on overseas domestic work was introduced, even among overseas employment agencies, because the ban was not publicized clearly (NapierMoore 2017). Creating channels of communication to ensure that migrants and other stakeholders, such as overseas employment agencies, understand requirements and restrictions can make enforcing them more efficient and can improve the ability of these policies to protect migrant workers.

The information that is available on the Department of Labor's website is difficult to find, and some of it is out of date and incomplete. Most of the information is only available in the form of PDFs or pictures, which migrants tend to avoid because viewing them incurs data charges on their mobile phones. Digital dissemination of information about labor migration would expand its reach significantly, but the way people in Myanmar are likely to access this type of information must be considered. 
The system for managing administrative data related to migration makes it difficult to translate this data into information that is useful to potential migrants and other labor market stakeholders. Much of the process of managing information in the migration management system is done manually. Demand letters are received and transmitted between government agencies and overseas employment agencies in Myanmar and abroad via e-mail and in hard copy; they are not captured in a single information management system. This makes tracking demand letters, overseas employment agencies, and individual migrants challenging, and it increases the time and administrative costs involved in managing the international migration system. If demand letters were incorporated into the Labor Exchange Office Management System and posted online, the visibility of the vacancies would increase and migrants would have more information when deciding about migration.

\section{Job matching and placement}

The private sector is deeply engaged in providing job-matching and -placement assistance to international migrants, primarily through recruitment agencies. Companies wishing to recruit workers for employment abroad must obtain a license from the Department of Labor. The LROE assigns responsibility for overseeing recruitment of workers for employment abroad to the OESC. The LROE and Ministerial Order 560/2014 regulate the activities of overseas employment agencies. Individuals wishing to provide overseas recruitment services must apply with a fee to the Migrant Worker Division in the Department of Labor for a license. ${ }^{15}$ Agencies wishing to recruit workers for employment in Thailand must apply for a special license, in addition to the general license for overseas recruitment. Agencies must send a minimum number of migrant workers abroad each year to maintain their license. ${ }^{16}$ The Department of Labor can cancel or revoke a license for violations of its conditions. The recruitment agencies can be punished for violations with imprisonment for one year or with a fine of MMK5,000. The LROE mandates that overseas employment agencies communicate with overseas employers and are responsible for migrant workers if their rights are infringed upon. The agencies must submit information on overseas employment to the Department of Labor.

As of August 2018, there were 258 licensed overseas employment agencies (Figure 3.3). Sixteen of these were temporarily banned from sending workers abroad. One hundred and eight were specially licensed to recruit workers for employment in Thailand. The number of agencies has increased over time. While all of the agencies have headquarters in Yangon, they frequently open local branches or have representatives outside of Yangon. ${ }^{17}$ Before opening these offices or contracting with the representatives, the agency must obtain permission from the Migrant Worker Division. The Department of Labor informs state and region Department of Labor offices that a local branch or representative has been authorized to operate. These local branches or representatives sometimes

\footnotetext{
15 The government announced that the deposit fee would be increased from MMK5 million (US\$3,650) to MMK50 million (US $\$ 36,500$ ) in January 2017 (ILO 2018).

16 This is reported to be 300 workers per year for Thailand (ISSARA INSTITUTE 2018).

17 For example, there were approximately 14 local branches of overseas employment agencies operating in Ayeyarwady in early 2018.
} 


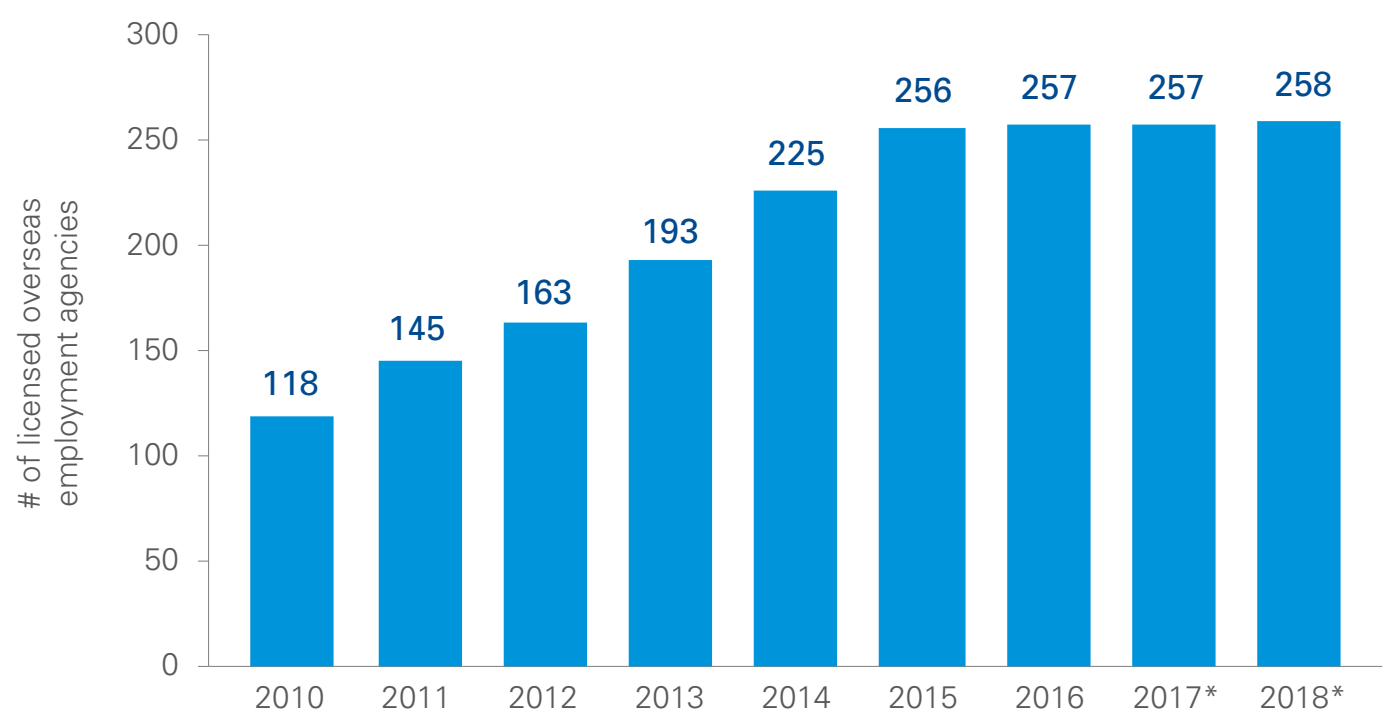

* Data for 2017 is through September. Data for 2018 is through August. Source: MOLIP 2016.

operate for a limited period to fulfill an employment request from abroad. Despite the existence of this formal recruitment system, informal brokers frequently connect potential international migrants to licensed overseas employment agencies. These informal brokers may even pay recruitment agencies to place workers, rather than the recruitment agencies paying the brokers to identify potential workers (ISSARA Institute 2108).

Overseas employment agencies and informal brokers are an essential part of the recruitment process in Myanmar. Currently, a migrant is not able to migrate formally without the involvement of a licensed overseas employment agency. In general, the agencies receive a demand letter from employers and recruitment agencies abroad requesting workers, and they investigate the opportunity. The agencies sometimes pay for or trade demand letters. The agencies then transmit the demand letter to the Migrant Worker Division, which then forwards it to the Education, Health, and Human Resources Development Committee for approval. For recruitment to proceed, approval by the Committee is necessary. For their part, migrants often engage with overseas employment agencies either through an informal (unlicensed) agent, who may help them obtain documentation and then hands them off to a licensed overseas employment agency, or through the local branch of a licensed agency. Recruitment agencies may pool and screen potential migrants to fill the demand once job orders are received (Verité 2019). ${ }^{18}$ Private training providers sometimes offer overseas job matching assistance, although a licensed overseas employment agency must do the actual recruitment if the migration is to be considered formal (Milio, Garnizova, and Shkreli 2014). Relatives, friends, and community members also refer potential migrants to informal brokers

18 The screening process may involve evaluating whether a potential migrant has the necessary documents to migrate, such as a job passport (Verité 2019). 
and recruitment agencies who facilitate employment abroad (Verité 2019).

Overseas employment agencies tend to focus on several countries for recruitment; each destination country has slightly different procedures and often requires workers with certain skill sets. The agencies may specialize in workers for the higher-skills markets in the Middle East or Singapore or in workers for the lowerskills markets in Thailand and Malaysia. In most cases, the overseas employment agencies work with a recruitment agency in the destination country, although in some cases, the agencies work directly with employers.

The market for recruitment services to Thailand, the most important destination country, is competitive. As Figure 3.3 shows, the number of recruitment agencies in Myanmar has increased in recent years, as has the number recruiting specifically to Thailand. Competition has led agencies to reduce their prices, has limited the bargaining power of Myanmar agencies with Thai employers and their agents, and limited the investment of Thai employers and their agents in providing services that ensure a safe migration experience (ISSARA Institute 2018). Thailand restricted the fees that can be imposed by Thai recruitment agencies on migrant workers, and since then, there have been reports that Thai agencies have auctioned job orders to Myanmar recruitment agencies who have in turn paid Thai agencies for job orders (Verité 2019).

The recruitment process for Myanmar migrants is unique for Korea and Japan. A government agency in Myanmar, the
Public Overseas Employment Agency (POEA), manages recruitment of migrant workers for Korea's Employment Permit System. Online Appendix 4 describes this process in detail. The Memorandum of Cooperation (MOC) signed with Japan adds additional requirements for recruitment agencies to send workers to Japan. The agreement creates "Approved Sending Organizations," which are overseas employment agencies that meet criteria laid out in the MOC, such as selecting and sending to Japan motivated individuals who understand the objectives of the Technical Intern Training Program; publicizing the fees collected from migrant workers; and not having financial connections to the migrant workers.

The LROE permits the Overseas Employment Supervisory Committee to determine fees charged to migrants by recruitment agencies. Overseas employment agencies are reportedly permitted to charge MMK150,000 (US\$112.50) per migrant worker for migrants to Thailand (for two years of work). ${ }^{19}$ The agencies can charge US\$850 per migrant worker for migrants to Malaysia. ${ }^{20}$ The fee is US\$2,800 for Japan and between US\$1,880 and US\$4,400 for Singapore (ILO 2016). The MOC with Japan requires "Approved Sending Organizations" to publicize the fees collected from migrant workers and explain how they are calculated. Migrants reportedly pay nearly the entire cost of recruitment, both on the Myanmar side and the Thailand side, including additional fees for brokers or informal agents who connect them with recruitment agencies (ISSARA Institute 2018). There are two payment schemes: a migrant pays part of

\footnotetext{
19 The agencies report that expenses, including travel, documentation, and investigation of the employer are around MMK90,000, meaning that the agency makes around MMK60,000 per migrant worker. There was formerly a limit of 10,000 Thai Baht that recruitment agencies in Thailand could charge (ISSARA INSTITUTE 2018). Thai employers and recruitment agencies are no longer permitted to make salary deductions (of up to this amount), although the application of this restriction on deductions is unclear in practice (Verité 2019).

20 The agencies report that they are only able to charge US\$700. Expenses paid to comply with procedures in Malaysia are around US $\$ 450$. The agencies thus report that they make around US\$100 per migrant worker.
} 
the fee to the broker upfront at the village level and then pays an additional fee to the Thai agent at the border, or the migrants pays the entire fee upfront.

The relationship between international jobseekers and public and private providers of job-matching and -placement services continues beyond the placement of a migrant worker in a job. As described previously, overseas employment agencies remain involved with migrants after recruitment is complete; they shepherd the migrants through the premigration process, from receiving predeparture orientation and medical examinations to obtaining the OWIC. In some cases, this relationship can continue even after the migrant worker is placed in a job abroad, and can include assistance for migrants while they are working abroad, assistance to help migrant workers return, assistance to help reintegrate migrants into the workforce once they have returned, and engagement in the resolution of complaints. However, recruitment agencies in Myanmar may work only with a recruitment agency in the destination country, not the employer itself (ISSARA Institute 2018). Government support supplements the provision of services by the private sector in each of these areas.

\section{Assistance while working abroad}

International migrants, particularly undocumented migrants, often lack protection in the destination country. One study found that 54 percent and 74 percent of Myanmar migrants in Thailand and Malaysia, respectively, held regular legal status during their employment in these countries (IOM and ARCM 2015). A small share labout 12 percent and 7 percent in Thailand and Malaysia respectively) did not receive statutory labor rights, such as annual leave, paid holidays, sick leave, minimum wage, and overtime pay. Migrants working in fisheries were most affected, with a quarter not receiving labor rights. Irregular migrants were also more affected, with 12 percent not receiving any labor rights, relative to 9 percent of regular migrants. Irregular migrants report paying bribes to officials to avoid arrest and detention, and they are less likely to have recourse to protection (Soe Lin Aung 2014; IOM and ARCM 2015).

The majority of migrants have no access to social protection. A 2016 study found that only 18 percent of Myanmar migrants were covered by some form of social protection, usually health insurance or another form of social security, although use of that protection was typically low due to high upfront costs or lack of awareness or interest (Harkins, Lindgren, and Suravoranon 2017; Harkins 2019). Another study found that Myanmar female migrants in Thailand rarely received maternity or other social security benefits (MMN 2016). Nearly 17 percent of surveyed migrants in the study had been fired because of pregnancy or on their return after maternity leave, 7 percent were not granted maternity leave, while another 5 percent were compelled to do unsafe work during pregnancy. And despite the legal right to birth registration for all children born in Thailand, a large share of migrant children do not receive a birth certificate. Other child protection services are also stretched to capacity or inadequate (Harkins 2019).

Although most migrant workers report their working conditions as adequate or good, labor rights abuses are widely reported. A 2013 migrant worker survey in Thailand found that only 4 percent of respondents reported their working conditions as bad or very bad, while 60 percent and 33 percent found them adequate or good, respectively (IOM and ARCM 2013). In 
a 2016 survey, however, nearly half of Myanmar migrants surveyed in Thailand and Malaysia reported labor rights abuses, such as excessive overtime, payment below the minimum wage, confiscation of ID documentation, restrictions on movement, withholding of wages, and illegal wage deductions (Harkins, Lindgren, and Suravoranon 2017). Migrants working in Thailand and those working in fisheries (81 percent), domestic work (69 percent), and hospitality and food (63 percent) were the most affected (Box 3.1). Many found employment contracts were misleading about actual work conditions. Studies of migrant workers at the Myanmar-Thailand border documented significant workplace and security-related stressors, such as excessive overtime, threats or experience of violence (especially for sex workers), and restrictions on freedom of movement (Meyer et al. 2015; IOM 2019). Many of these stressors had adverse impacts on the mental health of migrant workers.

Domestic workers are particularly vulnerable to exploitation and sexual harassment due to their isolated working conditions, high level of dependence on the employer, and fear of retaliation and violence (Thanasombat 2004). A study in Singapore found that Myanmar domestic workers, mostly women, worked long hours, many did not get their statutory day off each week, and they were not allowed to unionize (Napier-Moore 2017). Migrant sex workers usually have an irregular and precarious legal status in Thailand, in part due to lack of regular migration channels as well as criminalization and stigmatization of sex work (Harkins 2019).

Some assistance is available to migrants while they are abroad, particularly in the case of injury or death. The Myanmar Overseas Employment Agencies Federation has a call center in Thailand to address the complaints of migrant workers. ${ }^{21}$ Recruitment agencies may also have representatives in Thailand to address complaints. Renewal of work permits for extended stays abroad are generally not the responsibility of Myanmar overseas employment agencies. Myanmar's labor attachés provide assistance to migrant workers employed abroad, including working with migrant associations and NGOs in host countries to provide legal services to migrants. The attaché also does some promotional campaigning during festival periods to raise awareness among migrant workers that they can contact the attaché. The OWIC provided to all formal migrants has the migrant's passport number, the name and address of the licensed overseas employment agency, and the name of the factory where the migrant is working. This allows the migration authorities in Myanmar to contact workers, and it allows workers to contact labor attachés and the Myanmar embassy in case of need. Myanmar has also helped informal migrants in Thailand obtain legal status through Thailand's nationality verification process. ${ }^{22}$

Often migrants do not ask for help. Among the surveyed Myanmar migrants in Thailand and Malaysia who reported labor rights abuses, the majority (61 percent) sought no assistance for fear of repercussions or loss of employment (Harkins, Lindgren, and Suravoranon 2017). Those that did seek assistance did so from friends and families or from their employer. Hardly anyone used the consulate. Many destination countries do not allow migrant workers to join unions; even when joining them is allowed, migrant

21 The MOEAF had a call center in Malaysia until it was closed in March 2015.

22 The feasibility of establishing a migrant welfare fund to finance services for migrants while they are abroad has been explored by the Department of Labor with the support of the ILO, and such a fund may be included in a new overseas employment law (Win 2015). The Department of Labor has previously described the need for a welfare fund in the context of providing resources for repatriation of and legal services for migrant workers who are in distress. 
workers can face discrimination due to ethnicity, nationality, and gender. Women migrant workers sometimes face additional barriers to seeking legal aid, especially domestic workers in isolated working conditions or undocumented migrants subject to restrictions on movement (UN Women 2017).

Limitedassistanceisavailable to dependents of migrant workers while they are working abroad. Family members concerned about a migrant who is abroad can contact the MRC, which is then able to work with the Migrant Worker Division to identify the migrant's recruitment agency, their employer, and their location, and identify a way for family members to get in touch with them. MRCs can also help connect family members with the appropriate resources to file complaints. CSOs fill a gap in services for dependents of migrant workers; for example, CSOs operating in southeastern Myanmar provide courses for the children of migrant workers (Free and Just Women Group) and skills training for the family members of migrants working abroad (Karen Development Network).

\section{Assistance with return}

Myanmar assists with the repatriation of workers detained in Myanmar and undocumented workers in Thailand. When Thailand arrests and deports undocumented migrant workers, an immigration officer in Myawaddy receives them. A labor officer then documents their arrival, provides them with a dormitory, and helps them obtain a bus ticket home. The IOM provides safe migration information at the Immigration Deportation Centre to migrant workers in Thailand who are being deported.

Recruitment agencies may be involved in repatriation but are not required to by law. The LROE does not require recruitment agencies to assist with the repatriation of migrantworkers. However, in cases in which there is a dispute between a worker and a licensed overseas employment agency, the Myanmar Overseas Employment Agencies Federation (MOEAF) facilitates repatriation (ILO 2016a). The MOU with Thailand does require the governments of Myanmar and Thailand to cooperate to ensure that workers return home after the end of their contract or upon termination of the contract. The MOU also requires the Myanmar and Thai authorities to maintain a list of migrant workers, including those who have returned after employment. This includes requiring employers of migrant workers in Thailand to inform Thai authorities when migrant workers leave employment. MOEAF's Code of Conduct, which is discussed in detail below, includes a recommendation for overseas employment agencies to facilitate the return of migrant workers in cases of serious injury, death, natural disaster, or conflict..

The Myanmar Sustainable Development Plan (2018-2030) encourages the development of measures to encourage the diaspora to contribute to the Myanmar economy. However, explicit policies to encourage the return of high-skilled Myanmar migrants or to engage with the diaspora have not been formulated. The Myanmar government has, so far, focused on how economic growth and job creation could lead to the return of Myanmar's diaspora.

\section{Assistance with reintegration}

Some evidence suggests that while Myanmar migrants acquire skills abroad, they do not necessarily use them on their return. A study of migrants in Thailand reported some skill acquisition, but 79 percent of the respondents did not think 
that those skills would be useful for similar jobs in Myanmar, and they were not sure they would find jobs when they returned (Harkins, Lindgren, and Suravoranon 2017). Among unskilled and semi-skilled migrants, mostare unable toapply their newlyacquired skills on their return (Jirattikorn 2015). For instance, only 29 percent of returnees in Mon state were able to apply their skills in their communities of origin (Min Zar $\mathrm{Ni}$ 2018). The majority felt that their skills did not match the local labor requirements. $A$ study that examines Myanmar employer preferences for professional returnees versus nonmigrants found no significant preference in accounting or engineering firms (Saw Htay Wah 2015). There was some preference, particularly by foreign firms, for returnees with IT experience acquired abroad (particularly returnees from Singapore rather than Malaysia). The employers may have required countryspecific experience in accounting and engineering, indicating that not all skills are transferrable to the Myanmar market.

Return migrants are sometimes forced to remigrate because of low pay in their home communities. In addition to low demand for their higher skill levels, local wages are often low relative to wages abroad. Even returnees who had used their savings to buy land for cash crop cultivation (for example, rubber and betel nuts) found that cash income generated from farming at home was lower than their wages in the same sector in Thailand, and many chose to migrate again for work (World Bank and CESD 2018).

The programs that reintegrate returning migrant workers are very limited. The LROE assigns to the OESC the responsibility to use the knowledge and skills of returning workers. MRCs can help returning migrants obtain certificates describing their work abroad and can provide information about employment opportunities. The MRC in Pathein in Ayeyarwady Region reported that they had received reports from the Unionlevel listing the migrant workers who had returned home. The MRC confirmed that these workers had returned and contacted them about job fairs. The MOEAF's Code of Conduct, which is described in more detail below, recommends that overseas employment agencies provide information to returning workers about employment opportunities in Myanmar and abroad.

The private sector sometimes gets involved in the reintegration of migrant workers. For example, migrant workers who have worked in Korean and Japanese companies are sometimes offered jobs in those companies' branches in Myanmar (Oo 2017). The MOC with Japan requires that overseas employment agencies sending workers to Japan help those workers find jobs when they return home in occupations utilizing the skills acquired abroad. One recruitment agency describes funneling return migrants who had worked in Qatar to hotels in Myanmar that needed experienced workers.

One of the components of the IOM's PROMISE ${ }^{23}$ project, which covers Myanmar in addition to Cambodia, Lao PDR, and Thailand, will be devoted to return and reintegration. This component involves certification and referral mechanisms for returning migrants, assists policy makers in the development of return and reintegration policies, and offers capacity building for CSOs to provide entrepreneurship training to returning women migrant workers.

23 The acronym stands for Poverty Reduction through Safe Migration, Skills Development and Enhanced Job Placement in Cambodia, Lao People's Democratic Republic, Myanmar and Thailand. 
Table 3.3

Complaints received between 2014 and August 2017

\begin{tabular}{|c|c|c|c|c|c|c|c|}
\hline $\begin{array}{l}\text { Contract } \\
\text { dispute }\end{array}$ & Death & Injury & $\begin{array}{c}\text { Fee } \\
\text { dispute }\end{array}$ & $\begin{array}{l}\text { Missing } \\
\text { person }\end{array}$ & Arrest & Other & Total \\
\hline 184 & 223 & 100 & 186 & 37 & 87 & 457 & 1274 \\
\hline
\end{tabular}

Source: Oo 2017.

\section{Complaint mechanisms}

There are several mechanisms that migrant workers can use to report complaints regarding their recruitment experience and their employment abroad. ${ }^{24}$ There are no criteria for the types of complaints that can be lodged. Complaints Mechanism Centers in Yangon at the Regional Department of Labor Office and in Nay Pyi Taw receive complaints from internal and international migrants, and refer them to the relevant division in the Department of Labor. Table 3.3 shows the number of complaints made at the Complaints Mechanism Centers between 2014 and August 2017. LEOs can also receive complaints, which are then funneled to the Complaints Mechanism Centers for processing. In Magway Region, for example, in 2017 and early 2018 one complaint arose from the Complaints Mechanism Centers while approximately 4 were reported to LEOs and 2 to the region government. If a dispute arises between a migrant worker or a potential migrant worker and an unlicensed broker, the anti-trafficking police are called. Migrants, their families, CSOs, and others can file complaints either in-person or via a letter. Recruitment violations can be punished with license revocation, imprisonment, and fines.

When a complaint is lodged by a migrant, representatives from MOEAF and a
LEO investigate it. The Department of Labor attempts to negotiate between the employment agency in Myanmar and/or the country of destination and the worker. At times, the labor attaché is also involved. MOLIP can suspend or revoke the overseas employment agency's license if they do not cooperate with the investigation. The agency may be forced to compensate the migrant, including from the deposit paid upon receiving its recruitment license. If the dispute cannot be resolved through negotiations, a formal investigation team may be established involving the Head Officer of the state or region Department of Labor office, an LEO officer, and perhaps a representative from MOEAF. The cases in which formal teams are created are rare. In the case of complaints about unlicensed brokers, the Department of Labor only has jurisdiction if the broker is found to be a registered local agent of an employment agency. Otherwise, the case is passed to the Ministry of Home Affairs where it is investigated by the Anti-Trafficking in Persons Division. In 2014, punishments were handed out in three cases of recruiting without a license (ILO 2016a); between December 2013 and March 2016, 11 overseas employment agencies had their licenses temporarily suspended and 9 had them revoked as a result of a variety of complaints, including ones related to recruitment fees, employment contracts, and injuries (ILO 2016a). 
There are three other options for migrants who want to report complaints. While abroad, workers can file a complaint with the Myanmar Embassy or with the labor attaché in the destination country. In this case, the worker, the employer, and the overseas employment agency attempt to negotiate a resolution. Migrants can also report a complaint to MOEAF by letter, via a 24-hour hotline, or at its office in Yangon or Bangkok ${ }^{25}$. In this case, MOEAF notifies MOLIP and then investigates the complaint. This investigation is done in person in Thailand and Malaysia. As with the other complaint mechanisms, MOEAF tries to broker a solution between the worker, the employer, and the agency. In cases when the complaint cannot be resolved in the destination country, MOEAF seeks resolution in Myanmar between the overseas employment agency and the worker and, if this does not work, MOLIP's assistance is enlisted. Where complaints related to employment contracts and accommodations cannot be resolved, the agency is responsible only for reimbursement of the worker's recruitment fees. MOEAF itself maintains a blacklist of Thai and Malaysian employers and Thai recruitment agencies. Finally, complaints can be reported to the ILO's forced labor complaints mechanism and, less formally, to CSOs and labor organizations.

To improve recruitment practices through self-enforcement, MOEAF has created a Code of Conduct and a mechanism for monitoring compliance. The Code of Conduct, which was coordinated among MOLIP, MOEAF, and the ILO, is designed to encourage recruitment agencies to protect the rights of migrants and improve service quality. The Code includes minimum standards for providing documents, training, and protection, and it outlines the responsibilities of overseas employment agencies regarding their agreements with migrant workers, their agreements with overseas employers, and the employment contracts between employers and migrant workers. Of the 258 licensed agencies, 183 had signed the Code of Conduct as of late 2018 (ILO 2018). The Code Compliance and Monitoring Committee is made up of representatives from MOLIP, the antitrafficking unit, participating recruitment agencies, migrant workers, and a legal and labor expert (MOEAF 2016). The Committee was created with 7 members in August 2017. Seventy-three overseas employment agencies attended a training on the Code of Conduct and the monitoring mechanism. The Code of Conduct will be used in several ways; first, the overseas employment agencies will be ranked using a star system, where one star denotes weak compliance and three stars denotes full compliance with the Code (ILO 2018). These rankings can be used by MRC officers to inform potential migrants about high-performing agencies, and they will also be available online. Second, MOLIP will award high-ranking agencies to recognize their performance. Finally, destination countries are being encouraged to only use recruitment agencies that have signed the Code of Conduct; so far, only Japan has done so.

\section{Areas for improvement and potential gaps}

International migrants rely heavily on social networks to find jobs in some countries, and brokers and formal recruitment channels for other countries. The use of social networks is particularly extensive among those moving to Thailand and Malaysia, with migrants either making the move independently or through friends and family. For instance, in 2013, according to IOM staff estimates, 42 percent of

25 MOEAF had an office in Kuala Lumpur, Malaysia that was closed in March 2015 
Myanmar migrants in Thailand had used a broker, and only 1 percent reported using the formal MOU recruitment channel. A 2018 survey of migrants working in the agricultural sector in Thailand found that 22 percent of the surveyed Myanmar migrants used brokers, while the overwhelming majority used their social networks or migrated independently (Harkins 2019). A 2018 survey of migrants crossing the Myanmar-Thailand border reported that the overwhelming majority of migrants had arranged for jobs before their departure, and this was particularly true for those who had already worked in Thailand (IOM 2019). The use of social networks is less common for emerging destinations such as Korea, Japan, and Singapore, where recruitment agencies and brokers are more widely used for both job searches and travel arrangements (ILO 2015c; Harkins, Lindgren, and Suravoranon 2017; World Bank and CESD 2018).

Aspiring international migrants from border states have a long migration history and extensive cross-border social networks. ${ }^{26}$ Most migrants have family members, relatives, and friends, often from the same village, already living and working in Thailand or Malaysia, and migrants tend to move to the same location and often to the same employer as their contacts. However, migrants from nonborder areas, including two-stage migrants (that is, internal migrants from the Delta and Dry Zone who move first to Shan and the Southeast before deciding to migrate abroad), lack these social networks (ILO 2015c; Pattison et al. 2016b; World Bank and CESD 2018; Deshingkar, Litchfield, and Ching-Ting 2019).

Although extremely valuable in the absence of job-matching services and other support, such social networks can be limiting. Migrants learn only about the experience of their friends and family who have migrated before, so they are not fully aware of alternative experiences and opportunities that would enable them to make informed decisions. Brokers can help potential migrants move beyond traditional destinations; for instance, a small share of nonpoor households in Ayeyarwady and Magway report using brokers to move beyond their networks and take advantage of the capacity of such households to take risks (Pattison et al. 2016).

Reliance on brokers for job searching is more common among migrants from the Dry Zone (Mandalay and Magwe) and the Delta (Figure 3.4) who lack social networks. The relatively high share of brokers for migrants from Mon, Kayin, and Tanintharyi is likely due to using them for making travel arrangements and for documentation, and not necessarily for job searches (World Bank and CESD 2018). A study in three states and regions found that nearly 31 percent of aspiring international migrants planned to use brokers or recruitment agencies; this plan reflects the preferences of aspiring migrants in Mandalay who had fewer social networks relative to those in Shan and Tanintharyi (ILO 2015c). For instance, a 2017 household survey found that international migrants from Rakhine and Mandalay were more likely to use brokers or recruitment agencies relative to those from Ayeyarwady and Shan (Deshingkar, Litchfield, and Ching-Ting 2019).

While recruitment agencies and brokers can make migrants aware of opportunities, many of them are unlicensed and expose migrants to exploitation and trafficking. Brokers are often used to facilitate irregular migration by helping workers navigate border checks and travel to their destination. Many also introduce migrants 


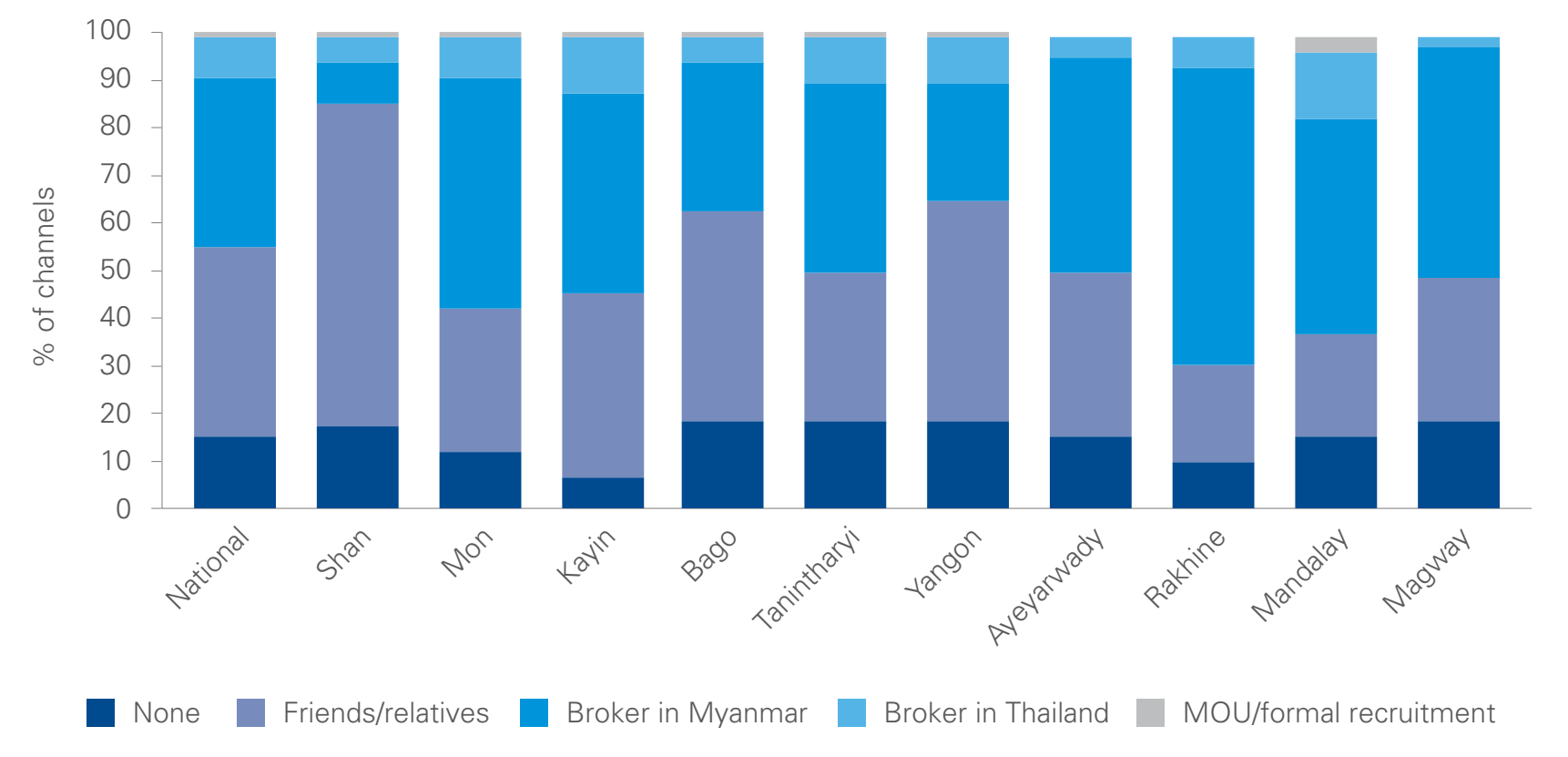

Source: IOM staff estimates.

to potential employers in the destination location. Studies highlight that brokers can operate in deceit, which can result in debt bondage and exploitative working conditions for migrants from Myanmar to Thailand (Meyer et al. 2014), especially in the fisheries sector (Robertson 2011; ILO 2013b, 2018), agriculture (Harkins 2019), and domestic work (Anderson 2016; Napier-Moore 2017; UN Women 2017) (Box 3.1).

Migrant-sending households are often concerned about the security of potential migrants, particularly when they are women. The security of finding accommodations and having a network of friends and family at the destination are important considerations. Many migrant-sending households also cite family responsibilities and social norms as constraints on the migration of women. Because the decision to migrate is often part of a household livelihood strategy, these decisions are frequently made by parents, rather than by the migrants themselves, especially in the case of young women. In some cases, parents of young, single women will not allow them to migrate. Their concerns, along with the stigma sometimes attached to female international migrants, can impose additional barriers for young women who want to move to urban areas or abroad (Pattison et al. 2016; UN Women 2017; World Bank and CESD 2018; Deshingkar, Litchfield, and Ching-Ting 2019).

A system for licensing overseas employment agencies is in place in Myanmar; however, enforcement of this system is generally responsive to complaints, rather than proactive in its oversight. The time-consuming approvals process for employment requests submitted by licensed overseas employment agencies and the lack of a proactive approach to enforcement may have created space for informal brokers to flourish. And the lack of information about employment opportunities abroad may also contribute to the reliance on informal brokers, especially in rural areas. 


\section{Box 3.1 Myanmar migrants in the fisheries sector in Thailand}

Trafficking and exploitation are significant problems in the fisheries sector in Thailand. Despite increased legislative efforts, trafficking and exploitation of migrants in the commercial fishing industry in Thailand is widely acknowledged (Solidarity Center 2009; Robertson 2011; ILO 2013b, 2018). For instance, a 2010 survey of Myanmar migrants in the seafood processing sector in one Thai province found 34 percent of the surveyed migrants had been trafficked, while 57 percent had been subjected to forced labor (LPN and John Hopkins 2011). In 2012, a survey of fishers employed in Thai commercial fishing boats reported that 30 percent of the surveyed Myanmar migrants were deceived or coerced into working in the sector (ILO 2013b). The 2012 survey also found that at least 84 percent of the surveyed Myanmar migrant fishers were either working in Thailand illegally or with an unclear legal status, while the majority (51 percent) had no documentation at all (ILO 2013b). Some migrants reported their employers either did not register them or did not allow them to register, and others cited long periods away at sea that prevented them from meeting the registration deadlines, while a large share mistakenly believed themselves to be registered.

There is some indication the situation may be improving. Policy and regulatory reforms might have contributed to positive developments in the regularization of migrant workers. A 2017 survey found that almost all surveyed fishers had identity documents, and only 13 percent of the surveyed migrants (including Cambodian and Myanmar migrants) lacked work permits. More than a third of the workers surveyed had signed a contract (as per the 2015 Thai law requiring that all workers on fishing boats sign a contract and receive a copy of it) (ILO 2018). In 2013, child labor was also a challenge, with nearly 8 percent of the migrants surveyed being children and youth (ILO 2013b). The 2017 survey found that less than one percent of workers surveyed was younger than eighteen (ILO 2018). In 2018, a formal recruitment framework (the MOU) between Myanmar and Thailand for work on fishing vessels was developed (Verité 2019).

However, labor abuses remain. A key factor is the involvement of unscrupulous agents or brokers in deceptive practices, exploitation, and trafficking. For instance, a 2010 survey found that between 80 and 90 percent of Myanmar migrants were employed in debt bondage situations (LPN and John Hopkins 2011). In 2012, over 50 percent of the Myanmar migrant fishers surveyed reported borrowing from brokers or employers to finance their migration, leaving them open to potential exploitation and debt bondage (ILO 2013b). In 2017, 17 percent of surveyed workers reported that conditions were worse than promised (compared to a figure of 15 percent among surveyed fishers in 2013). Workers were misled about the hours they would need to work, the wages they would be paid, and the dangers of the work itself. There was significant evidence of labor rights abuses in terms of workers being paid less than the promised or minimum wage, wage withholding or deductions, and identity document retention by employers (ILO 2018).

Despite the difficult and dangerous working conditions and low remuneration, Myanmar migrants continue to work in the fisheries sector. Lack of labor market information that leads migrants to accept the first job offered, fear of arrest that attracts irregular migrants to work on boats away at sea, and opportunities to save money while away at sea are all factors motivating Myanmar workers to continue seeking out work in the fisheries sector (Solidarity Center 2009; ILO 2013b).

Source: Authors. 
LEOs are not actively engaged in the oversight of overseas employment agencies or the local branches of those agencies. This is partly by design: LEOs are meant to be responsible for job matching within Myanmar, not recruitment oversight. However, the knowledge that LEOs have of the local labor market and about job matching in general could be valuable in making decisions about licenses for overseas employment agencies and their local agents. Officially giving LEOs a role in this oversight would likely require further coordination within the Department of Labor and MOLIP and across ministries, and clear lines of responsibility would need to be drawn. Currently, the Migrant Worker Division in Nay Pyi Taw takes charge of approving applications for licenses. LEOs do investigate informal brokers, but only after complaints are received.

Information about recruitment agencies is lacking. A list of licensed overseas employment agencies is available on MOLIP's website and is also posted on a bulletin board at the North Dagon training center in Yangon. However, this list is not available in other locations, and it contains little information about the agencies beyond their contact details. Staff at MRCs can provide potential migrants with some additional information, such as which recruitment agencies tend to send migrants to which destinations, and which recruitment agencies have a good reputation. However, no information about quality is available. ${ }^{27}$ As noted above, a ranking system for the overseas employment agencies is being developed by the MOEAF's Code Compliance and Monitoring Committee. However, this ranking is not yet being used to inform migrants about the quality of the agencies. Perhaps more importantly, there are few channels where migrants can obtain information about the quality of overseas employment agencies even when the ranking system is implemented. MRCs, which are the natural users of these rankings, seem to be visited by relatively few migrants. There are also concerns that migrants' input was not solicited when the Code Compliance and Monitoring Committee was created. Overall, recruitment is a passive process for migrants: they are directed to overseas employment agencies by informal brokers, rather than identifying for themselves overseas employment agencies based on the quality of their services.

The use of informal agents is common (Hall 2012; Win 2015). These brokers generally operate in rural areas where they have the trust of the local community. Informal brokers seem to take advantage of the time lag while demand letters are being approved to identify potential migrant workers for overseas employment agencies. The overseas employment agencies then pay finder's fees to these brokers, who have likely also charged (illegal) recruitment fees to migrant workers. Efforts to crack down on these brokers are generally in response to complaints rather than a result of an active enforcement program. Even in cases where local LEO officers become aware of an informal broker, they first have to determine whether or not the broker is registered by checking with the Head Officer of the state or region Department of Labor office, who then checks with Nay Pyi Taw about whether the broker is licensed. If the broker is not licensed, the anti-trafficking police can then be involved.

27 A survey of 625 potential migrants in Mandalay, Tanintharyi, and Shan in 2014 found that reputation was the most frequent factor cited by potential migrant workers when asked about the most important factor in choosing a recruitment agency or broker (ILO 2014b). Fortyeight percent cited reputation as the most important factor compared to 14 percent citing cost and 13 percent citing speed of deployment and reliability. 
The Employment Division does, at times, cooperate with international organizations, such as Save the Children to share information and raise awareness about informal brokers.

Informal brokers drive up the cost of recruitment for migrant workers. Myanmar places caps on recruitment fees, which are recognized by licensed overseas employment agencies. The MOEAF recognizes these caps as binding on the profits they can make. However, informal brokers who operate illegally do not adhere to these caps, and at times, charge migrants for connecting them to the licensed overseas employment agencies. A recent study found that Myanmar migrants to Thailand paid US\$400, nearly 4 times the cap, and Myanmar migrants to Malaysia paid US\$1,034, about 20 percent more than the cap (ILO and IOM 2017). To the extent that informal, illegal brokers continue to operate, fee caps will likely be difficult to enforce.

The assistance provided to migrant workers after they are placed in a job abroad can be strengthened. Enhancing the resources available to labor attachés will ensure that they can continue to support migrant workers while they are abroad. A migrant welfare fund should also be considered (see International Spotlight 12 in Chapter 4). Similarly, strengthening the ability of MRCs to support the families of migrant workers while they are abroad is an important task for the MRCs going forward. The responsibilities of the overseas employment agencies with respect to repatriation of migrant workers either after the expiration of their employment term or in case of distress or emergency is not currently specified in the LROE. This creates uncertainty and can even result in migrants becoming informal if there is a misunderstanding about who is responsible for organizing their return. The lack of a devoted source of funds for repatriation adds to this uncertainty.

Reintegrating migrants returning to Myanmar is important for building on the skills that migrants have gained abroad. This knowledge transfer is important for both the migrants themselves and for Myanmar's labor market, which would benefit from returned migrants' higher skill levels. Yet, reintegration policies are largely absent in Myanmar, as are policies for engaging the diaspora. Engaging with and incentivizing the return of Myanmar's diaspora could bring financial and human capital resources back to Myanmar, and create sources of learning for local experts and financial connections to destination countries (see International Spotlight 13 in Chapter 4).

Myanmar has developed a nascent complaints mechanism system with several formal channels for migrants to file grievances about recruitment. However, the process for addressing these grievances is largely informal, and it relies heavily on the MOEAF, which represents the interests of overseas employment agencies and not the interests of migrant workers. The roles and responsibilities of labor attachés in the complaints mechanism process do not seem to be formalized in the LROE or elsewhere (ILO 2016a). For cases in which issues between a migrant worker and the overseas employment agency cannot be resolved, the recruitment fees are reimbursed, but the additional costs incurred by migrant workers, such as unpaid wages, are not (ILO 2016a). While maintaining some level of informality in the dispute resolution process is practical, ensuring that migrant workers have an accessible, formal mechanism to fall back on in case of unresolvable disputes is essential. 


\section{Financial assistance}

International migration costs are high and vary by migration corridor. For instance, Myanmar migrants to Thailand can pay recruitment costs of about US $\$ 400$, accounting for about 3 months of their annual income, and those to Malaysia can pay about US $\$ 1,034$, nearly 4 months of their annual income (Harkins, Lindgren, and Suravoranon 2017). ${ }^{28}$ A 2017 household survey estimated the following median cost of international migration by destination (as reported by migrant-sending households): MMK2.65 million for Korea, MMK 1.5 million for Malaysia, MMK 500,000 for Thailand, and MMK250,000 for China (Deshingkar, Litchfield, and Ching-Ting 2019). ${ }^{29}$ Overall, Thailand and China are the least costly destinations, followed by Malaysia, and destinations like Singapore, Korea, and Japan are the more expensive (World Bank and CESD 2018). Migration costs are higher for some groups, such as women moving abroad for domestic work, despite the ban on doing so. Migration costs for domestic workers moving to Singapore can be as much as six to eight months' wages (US\$1,924-US\$2,565) (Napier-Moore 2017). Domestic workers also need to make informal payments to officials at various points in the migration process so that they are not deported.

Documentation and informal payments can add to the cost of migration. A survey in Mon state estimated that migration costs to Thailand were about MMK400,000 (approximately US\$250) for documented migrants and MMK250,000 (approximately US\$150) for undocumented migrants (Min Zar Ni 2018). In 2018, a passport cost MMK25,000 (approximately US\$16), but costs were higher with broker fees (World
Bank and CESD 2018). CSO representatives in Myawaddy also cite informal costs for documentation. For example, the cost of a Certificate of Identity could be as high as THB10,000 (approximately US\$300), which is much higher than the official price of THB2,800 (approximately US\$86). Following changes to the migration policy and regulations in 2017, some migrantsending households reported a drop in remittances received because migrants needed the funds for the regularization of their employment status in Thailand (World Bank and CESD 2018).

The need to travel long distances in order to migrate formally can add to the cost of migration. Travel time and cost from outlying areas of Myanmar may play a role in mediating access to overseas destinations, because all overseas recruitment agencies are registered in Yangon, and much of Myanmar's migration management infrastructure is in Yangon also. For instance, although migrants can obtain their passport to work abroad from their local passport office, many need to travel to Yangon to obtain their OWIC and to participate in pre-departure orientation. Overseas employment agencies often gather potential migrants in Yangon (World Bank and CESD 2018). Improving access to migration management infrastructure may incentivize the use of formal migration channels. There is anecdotal evidence that the opening of a passport office in Tanintharyi may have encouraged migrants to use regular channels (ILO 2015c).

Many households borrow to finance migration. Among international migrants to Thailand and Malaysia, more than half

28 These costs include official costs and recruitment fees (for those using brokers).

29 These costs include broker and recruitment agency fees, transportation, accommodation, and other costs but are based on small samples. 
used their savings to finance migration, but about 39 percent took out loans, 9 percent sold assets, and 15 percent financed their move through wage deductions (Harkins, Lindgren, and Suravoranon 2017). Similarly, 32 percent of aspiring migrants in three states and regions planned to borrow to finance their international migration (ILO 2015c). This proportion varied by place of origin; 55 percent of aspiring migrants in Mandalay, where there is greater reliance on regular channels and use of recruitment agencies, planned to take loans, compared with 7 percent in Shan and 26 percent in Tanintharyi.

Despite the prevalence of lending to finance migration, the lack of formal loan products targeted to migrants, and Myanmar's underdeveloped financial infrastructure, limit the ability of aspiring migrants to borrow from formal financial institutions at reasonable rates of interest. One innovative product is offered by the social impact business Proximity Designs. The On-the-Go Loan is offered to rural farm families with a migrant household member to help smooth their household income until remittances are received. The average loan size is MMK200,000. Beyond this product, there do not seem to be any financial assistance or financial products specifically designed for migrant workers. Given the high potential return from international migration, local moneylenders are willing to lend to aspiring migrants but at very high interest rates. ${ }^{30}$ Land is often used as collateral, and so in case of failed migration these households bear the risk of losing their already limited land holdings (ILO 2015c; Maharajan and Myint 2015).

Access to microfinance has increased since the financial sector reforms in 2012, but these products are not explicitly designed to finance migration. Between 2012 and 2017, the share of households able to borrow from the Myanmar Agriculture and Development Bank, Myanmar's largest microfinance provider, increased from 13 percent to more than 70 percent (Ma 2017). Aspiring migrants have begun to borrow from microfinance institutions at lower interest rates to finance their migration (World Bank and CESD 2018). However, these products are not designed for this purpose; many borrowers report that the short repayment cycle of microloans (every 14 days) is a challenge given that remittance receipt tends to be less frequent and lumpier. These borrowers also tend not to be among the poorest households. Poorer households with no collateral for loans resort to selling or pawning their limited assets to finance migration, while women also tend to rely on savings, either because they face lower migration costs (due to the choice of destination and migration channel) or because they lack access to credit (ILO 2015c).

The lack of access to affordable credit increases the risk of debt bondage. About 15 percent of aspiring migrants in three states and regions expected to pay back loans through wage deductions (ILO 2015c). This is a risky practice as it introduces the possibility of debt bondage (see Box 3.1). For women migrants, this risk is higher due to the prevalence and possible increase of deceptive practices after the ban on migrating for domestic work. A study of female migrants in ASEAN reported that agents would often register women migrants for nondomestic work prior to departure and then force them to sign new employment contracts for domestic work (with increased working hours and salary deductions) on arrival at the destination country (UN Women 2017). 


\section{Areas for improvement and potential gaps}

Devoted financial products linked to the unique experience of migrants, particularly to the remittances that many migrant workers send home, could ease the burden of financing migration. The lack of financial assistance for migration may limit migrants' access to good job opportunities abroad. However, products targeted to the needs of migrants have been developed in other countries. For example, loans backed by remittances and tailored to the unique needs of migrants and their households have been offered in Bangladesh (see International Spotlight 15 in Chapter 4).

\section{Conclusion}

While the migration management system in Myanmar is maturing, there are several areas that could be improved, even if the human and financial resource constraints remain. First, the management of the migration system is overly centralized. This is apparent in the requirement that every demand letter be approved by the high-level Education, Health, and Human Resources Development Committee. LEOs, which have knowledge of local areas throughout Myanmar, could be more formally involved in oversight of the migration system, particularly the recruitment component. Second, the systems for managing the intake, storage, and dissemination of information related to migration are underdeveloped; this is the case in the management of demand letters, the registration of jobseekers at LEOs, and the assignment of OWICs. While nascent information management systems exist, data input and information transfer are frequently done manually. At the same time, there are limited sources where international migrants can obtain information about job openings and about the recruitment agencies that are key to the job-search process. There are several examples of NGOs and CSOs that have created innovative, technologically informed information services that could be leveraged by the Government of Myanmar to expand the labor market information available to international jobseekers. Finally, there are gaps in services for international migrants; financial assistance targeted to migrants and financial literacy training are mostly absent, as are reintegration programs to support returning migrants and diaspora engagement policies to tap into the knowledge and skills of the Myanmar diaspora. MRCs are key institutions for supporting migrants and their families. However, at present the MRCs have limited resources and coverage on the one hand, and a broad mandate on the other. The low uptake of MRC's services by migrant workers suggests that more work may be needed to ensure that they provide services that migrants and their families find useful. Table 3.4 summarizes examples of ALMPs from other countries that could strengthen ALMPs in Myanmar. These examples are discussed in more detail in Chapter 4. 
Table 3.4

\section{Relevant examples from around the world of ALMPs serving international migrants}

\begin{tabular}{|c|c|c|c|c|}
\hline Area & $\begin{array}{c}\text { Program } \\
\text { name }\end{array}$ & Country & Country & Description \\
\hline \multirow{8}{*}{ 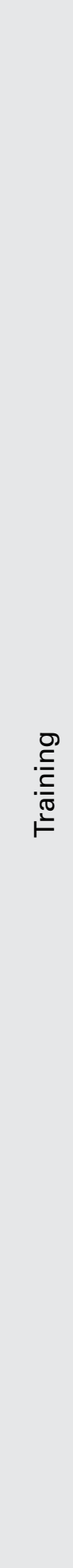 } & \multirow{3}{*}{$\begin{array}{c}\text { Predeparture } \\
\text { orientation }\end{array}$} & $\begin{array}{l}\text { Pre-Employment } \\
\text { Orientation } \\
\text { Seminar (PEOS) }\end{array}$ & Philippines & $\begin{array}{l}\text { - rovides information about the job search } \\
\text { and recruitment process to help domestic, } \\
\text { professional, and skilled Filipino workers decide } \\
\text { whether to migrate }\end{array}$ \\
\hline & & $\begin{array}{l}\text { Pre-Departure } \\
\text { Orientation } \\
\text { Seminar (PDOS) }\end{array}$ & Philippines & $\begin{array}{l}\text { Provides information to help Filipino workers } \\
\text { adjust to their working and living conditions } \\
\text { abroad }\end{array}$ \\
\hline & & $\begin{array}{l}\text { Comprehensive } \\
\text { Pre-departure } \\
\text { Education Program }\end{array}$ & Philippines & $\begin{array}{l}\text { - Training in language, culture, and stress } \\
\text { management, specifically for migrant domestic } \\
\text { workers }\end{array}$ \\
\hline & \multirow[t]{2}{*}{ Skills training } & $\begin{array}{l}\text { Punjab Skills } \\
\text { Development Fund } \\
\text { (PSDF) } \\
\text { Punjab TVET } \\
\text { Authority }\end{array}$ & Pakistan & $\begin{array}{l}\text { Undertook assessments of skills demand in } \\
\text { Gulf Cooperation Countries and have sought } \\
\text { to create a demand-driven training scheme } \\
\text { specifically for overseas workers }\end{array}$ \\
\hline & & $\begin{array}{l}\text { Technical } \\
\text { Education and } \\
\text { Skills Development } \\
\text { Authority (TESDA) }\end{array}$ & Philippines & $\begin{array}{l}\text { - Migrants must undergo a skills test administered } \\
\text { by TESDA demonstrating their skills qualification; } \\
\text { TESDA also seeks to cultivate professional and } \\
\text { personal relationships abroad }\end{array}$ \\
\hline & \multirow[t]{2}{*}{$\begin{array}{l}\text { Financial } \\
\text { literacy } \\
\text { training }\end{array}$} & $\begin{array}{l}\text { Pilot Program on } \\
\text { Financial Literacy } \\
\text { Education for } \\
\text { Migrant Workers } \\
\text { and Their Families }\end{array}$ & Indonesia & $\begin{array}{l}\text { - Curriculum was participatory, interactive, and } \\
\text { practical with positive impacts that were larger } \\
\text { when both the migrant and their family member } \\
\text { received the training }\end{array}$ \\
\hline & & $\begin{array}{c}\text { Project Greenback } \\
2.0\end{array}$ & Indonesia & $\begin{array}{l}\text { - Use financial education and expanded access to } \\
\text { the financial system to increase the efficiency of } \\
\text { the remittance market }\end{array}$ \\
\hline & $\begin{array}{l}\text { Post-arrival } \\
\text { orientation }\end{array}$ & $\begin{array}{l}\text { Post-arrival } \\
\text { Orientation } \\
\text { Seminar (PAOS) }\end{array}$ & Indonesia & $\begin{array}{l}\text { - Instruction on rights and responsibilities, } \\
\text { information on assistance available at diplomatic } \\
\text { missions, and information on community } \\
\text { activities } \\
\text { - Financial literacy programs also available through } \\
\text { Philippine banks and community organizations } \\
\text { - Information for migrants on their rights, the } \\
\text { culture of the destination country, services and } \\
\text { assistance available, and appropriate employer } \\
\text { expectations }\end{array}$ \\
\hline
\end{tabular}




\begin{tabular}{|c|c|c|c|c|}
\hline Area & $\begin{array}{l}\text { Program } \\
\text { name }\end{array}$ & Country & Country & Description \\
\hline 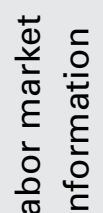 & $\begin{array}{l}\text { Overseas } \\
\text { vacancy } \\
\text { information }\end{array}$ & WorkAbroad.ph & Philippines & $\begin{array}{l}\text { - Job postings on the website are processed } \\
\text { and posted by recruitment agencies licensed } \\
\text { by the Philippines Overseas Employment } \\
\text { Administration }\end{array}$ \\
\hline \multirow{12}{*}{ 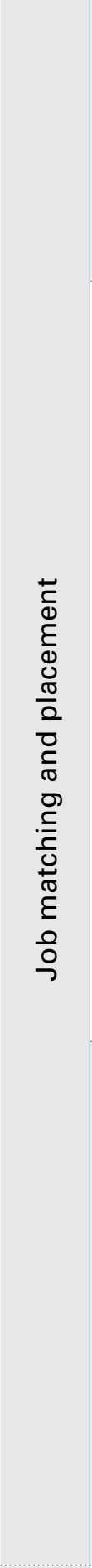 } & Welfare & $\begin{array}{l}\text { Overseas } \\
\text { Workers Welfare } \\
\text { Administration } \\
\text { (OWWA) }\end{array}$ & Philippines & $\begin{array}{l}\text { - Provides services for a fee to migrants including } \\
\text { legal assistance and insurance in the case of } \\
\text { disability and death, repatriation assistance, and } \\
\text { scholarships for dependents }\end{array}$ \\
\hline & & $\begin{array}{l}\text { Indian Community } \\
\text { Welfare Fund } \\
\text { (ICWF) }\end{array}$ & India & $\begin{array}{l}\text { - Provides services free to migrants in } \\
\text { emergencies }\end{array}$ \\
\hline & \multirow{5}{*}{ Reintegration } & $\begin{array}{l}\text { Assist WELL (Wel- } \\
\text { fare, Employment, } \\
\text { Legal, and Liveli- } \\
\text { hood) centers }\end{array}$ & Philippines & $\begin{array}{l}\text { - Connect returning migrants, particularly those } \\
\text { returning because of distress, with welfare, } \\
\text { employment, livelihood, and legal assistance }\end{array}$ \\
\hline & & $\begin{array}{l}\text { Balik-Pinay! Balik- } \\
\text { Hanapbuhay! } \\
\text { Program (BPBH) }\end{array}$ & Philippines & $\begin{array}{l}\text { - Livelihood support program providing skills, } \\
\text { entrepreneurship, financial literacy training, } \\
\text { and other services at no expense to returning } \\
\text { migrant workers, particularly returning migrant } \\
\text { women who left work abroad due to conflict, } \\
\text { policy change, recruitment difficulties, or human } \\
\text { trafficking }\end{array}$ \\
\hline & & $\begin{array}{l}\text { Enterprise } \\
\text { Development and } \\
\text { Loan Program }\end{array}$ & Philippines & $\begin{array}{l}\text { - Facilitates enterprise development through fixed } \\
\text { interest loans and entrepreneurship support }\end{array}$ \\
\hline & & $\begin{array}{l}\text { Livelihood Devel- } \\
\text { opment Assistance } \\
\text { Program }\end{array}$ & Philippines & $\begin{array}{l}\text { - Provides a business start-up kit, small business } \\
\text { training, and a financial awareness seminar to } \\
\text { returning undocumented migrant workers }\end{array}$ \\
\hline & & $\begin{array}{l}\text { Sa 'Pinas, Ikaw ang } \\
\text { Ma'am/Sir (SPIMS) }\end{array}$ & Philippines & $\begin{array}{l}\text { - Helps current and former migrant household } \\
\text { workers find teaching positions in the Philippines }\end{array}$ \\
\hline & \multirow{5}{*}{$\begin{array}{c}\text { Diaspora } \\
\text { engagement }\end{array}$} & $\begin{array}{l}\text { Researchers and } \\
\text { Scientists Abroad } \\
\text { program (RAICES) }\end{array}$ & Argentina & $\begin{array}{l}\text { - Facilitates shorts stay by scientists living abroad; } \\
\text { has resulted in the creation of a large database } \\
\text { of diaspora scientists }\end{array}$ \\
\hline & & $\begin{array}{l}\text { Ethiopian Diaspora } \\
\text { Volunteer Program } \\
\text { (EDVP) }\end{array}$ & Ethiopia & $\begin{array}{l}\text { - Similar to RAICES, but focused on medical } \\
\text { professionals }\end{array}$ \\
\hline & & $\begin{array}{l}\text { Brain Gain Network } \\
\text { Diaspora mapping } \\
\text { project }\end{array}$ & $\begin{array}{c}\text { Philippines } \\
\text { Jamaica }\end{array}$ & \multirow[t]{3}{*}{$\begin{array}{l}\text { Databases of talented diaspora abroad that } \\
\text { help create knowledge networks and connect } \\
\text { diaspora with job opportunities at home }\end{array}$} \\
\hline & & RedEsColombia & Colombia & \\
\hline & & Who Is Who in $\mathrm{BiH}$ & $\begin{array}{l}\text { Bosnia and } \\
\text { Herzegovina }\end{array}$ & \\
\hline 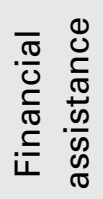 & $\begin{array}{l}\text { Mobility } \\
\text { support }\end{array}$ & $\begin{array}{l}\text { Migration loan } \\
\text { program }\end{array}$ & $\begin{array}{l}\text { Bangla- } \\
\text { desh }\end{array}$ & $\begin{array}{l}\text { - Provided loans between USD300 and USD3,700 } \\
\text { to migrants with work contracts and verified } \\
\text { travel documents to finance migration and } \\
\text { support household members left behind }\end{array}$ \\
\hline
\end{tabular}

Source: Authors. 


\section{References}

Akee, Randall, and Devesh Kapur. 2017. "Myanmar Remittances." Ministry of Planning and Finance (MOPF) and International Growth Centre (IGC).

Ambler, Kate, Diego Aycinena, and Dean Yang. 2015. "Channeling Remittances to Education: A Field Experiment among Migrants from El Salvador," American Economic Journal: Applied Economics 7(2):207-32.

Anderson, B. 2016. "Worker, Helper, Auntie, Maid? Working Conditions and Attitudes Experienced by Migrant Domestic Workers in Thailand and Malaysia." ILO and UN Women.

Chantavanich, S., and P. Vungsiriphisal. 2012. "Myanmar Migrants to Thailand: Economic Analysis and Implications to Myanmar Development." In: Lim H \& Yamada Y (eds.) Economic Reforms in Myanmar: Pathways and Prospects. Bangkok Research Centre Research Report 10. Bangkok.

Deshingkar, P., J. Litchfield, W. Ching-Ting. 2019. "Capitalising Human Mobility for Poverty Alleviation and Inclusive Development in Myanmar (CHIME)." International Organization for Migration, Yangon.

Doi, Yoko, David McKenzie, and Bilal Zia. 2014. "Who You Train Matters: Identifying Combined Effects of Financial Education on Migrant Households." Journal of Development Economics $109(C): 39-55$.

Hall, Andy. 2012. "Myanmar and migrant Workers: Briefing and Recommendations." Mahidol Migration Center, Institute for Population and Social Research, Mahidol University, Thailand.

Harkins, B. 2019. Thailand Migration Report 2019. United Nations Thematic Working Group on Migration in Thailand, Bangkok.

Harkins, B., D. Lindgren, and T. Suravoranon. 2017. Risks and rewards: Outcomes of labour migration in South-East Asia. International Labour Organization (ILO) and International Organization for Migration (IOM), Bangkok.

ILO (International Labour Organization). 2013a. "Regulating Recruitment of migrant workers: An Assessment of Complaint Mechanisms in Thailand." ILO, Bangkok.

ILO (International Labour Organization). 2013b. "Employment Practices and Working Conditions in Thailand's Fishing Sector." International Labour Organization, Bangkok.

ILO (International Labour Organization). 2014a. "Quarterly Briefing Note: GMS Triangle Project: Myanmar (July-September 2016)." ILO, Bangkok.

ILO (International Labour Organization). 2014b. "Safe migration knowledge, attitudes and practices in Myanmar." ILO, Bangkok. 
ILO (International Labour Organization). 2015a. "Review of the effectiveness of the MOUs in managing labour migration between Thailand and neighbouring Countries." ILO, Bangkok.

ILO (International Labour Organization). 2015b. “Internal Labour Migration in Myanmar: Building an Evidence-base on Patterns in Migration, Human Trafficking and Forced Labour." International Labour Organization, Yangon.

ILO (International Labour Organization). 2015c. "Safe Migration Knowledge, Attitudes and Practices in Myanmar. Tripartite Action to Protect the Rights of Migrant Workers within and from the Greater Mekong Subregion (GMS TRIANGLE project)." International Labour Organization, Bangkok.

ILO (International Labour Organization). 2015d. "Safe migration knowledge, attitudes and practices in Myanmar." ILO Regional Office for Asia and the Pacific, Bangkok.

ILO (International Labour Organization). 2016a. "Country of origin complaints mechanisms for overseas migrants from Myanmar: International standards, current mechanisms and practices from other countries." ILO, Yangon.

ILO (International Labour Organization). 2016b. "Triangle II Quarterly Briefing Note: Thailand. (JulySeptember 2016)." ILO, Bangkok.

ILO (International Labour Organization). 2017. "Building Labour Migration Policy Coherence in Myanmar." ILO, Yangon.

ILO (International Labour Organization). 2018. “Implementation of Recommendations from the 3rd to 10th ASEAN Forum on Migran Labour (AFML): Progress Review Background Paper for the 11 th ASEAN Forum on Migrant Labour (AFML)," ILO, Geneva.

ILO (International Labour Organization). 2019. "Digitalization To Promote Decent Work for Migrant Workers in ASEAN." Thailand, ILO.

ILO (International Labour Organization) and IOM (International Organization for Migration). 2017. "Risks and Rewards: Outcomes of Labour Migration in South-East Asia." ILO and IOM, Thailand.

IOM (International Organization for Migration). 2013. "Assessing Potential Changes in the Migration Patterns of Myanmar Migrants and Their Impacts on Thailand." IOM, Bangkok.

IOM (International Organization for Migration). 2015. "Migrant Information Note Issue \#28." IOM, Bangkok.

IOM (International Organization for Migration). 2016a. "Assessing Potential Changes in the Migration Patterns of Myanmar Migrants and the Impacts on Thailand: Supplementary Report." IOM, Bangkok.

IOM (International Organization for Migration). 2016b. "Migrant Information Note Issue \#29." IOM, Bangkok.

IOM (International Organization for Migration). 2019. "Flow Monitoring Surveys: Insights into the Profiles and Vulnerabilities of Myanmar Migrants to Thailand," IOM, Bangkok. 
IOM and ARCM. 2013. "Assessing Potential Changes in the Migration Patterns of Myanmar Migrants and Their Impacts on Thailand." International Organization for Migration and The Asian Research Center for Migration, Chulalongkorn University, Bangkok.

IOM and ARCM. 2015. "Supplementary Report: Assessing Potential Changes in the Migration Patterns of Myanmar Migrants and Their Impacts on Thailand." International Organization for Migration and The Asian Research Center for Migration, Chulalongkorn University, Bangkok.

Issara Institute. 2018. "Developing a Financially Viable Ethical Recruitment Model: Prospects for the Myanmar-Thailand Recruitment Channel," Issara Institute, Bangkok.

Jirattikorn, Amporn. 2015. "Managing Migration in Myanmar and Thailand: Economic Reforms, Policies, Practices and Challenges." Institute of Southeast Asian Studies (ISEAS), Singapore.

Kubo, Koji. 2017. "Evolving informal remittance methods among Myanmar migrant workers in Thailand." Journal of the Asia Pacific Economy 22(3):396-413.

Kubo, K. 2015. "Evolving Informal Remittance Methods of Myanmar Migrant Workers in Thailand." ERIA-DP-2015-45, Economic Research Institute for ASEAN and East Asia (ERIA) Discussion Paper Series.

LPN and John Hopkins. 2011. "Estimating Labour trafficking: A Dtudy of Burmese Migrant Workers in Samut Sakhon, Thailand." Labour Rights Promotion Network and Johns Hopkins School of Public Health, for the United Nations Inter-Agency Project on Human Trafficking, Bangkok.

Ma, Alex. 2017. "Labor Migration from Myanmar: Remittances, Reforms, and Challenges." Migration Policy Institute, Washington D.C.

Maharajan, A., and T. Myint. 2015. "Internal Labor Migration Study: In the Dry Zone, Shan State and the Southeast of Myanmar." HELVETAS Swiss Intercooperation Myanmar, Yangon.

Makovec, Mattia, Ririn S. Purnamasari, Matteo Sandi, and Astrid R. Savitri. 2018. "Intended vs. Unintended Consequences of Migration Restriction Policies: Evidence from a Natural Experiment in Indonesia." Journal of Economic Geography 18(4):915-50.

Meyer, S., M. Decker, W. Tol, N. Abshir, A. Mar, and W. Robinson. 2015. "Workplace and Security Stressors and Mental Health among Migrant Workers on the Thailand-Myanmar Border. Social Psychiatry and Psychiatric Epidemiology 51.

Meyer, S. R., W. C. Robinson, N. Abshir, A. A. Mar, and M. R. Decker. 2014. "Trafficking, Exploitation and Migration on the Thailand-Burma Border: A Qualitative Study." International Migration 53.

Milio, Simona, Elitsa Garnizova, and Alma Shkreli. 2014. "Assessment Study of Technical and Vocational Education and Training (TVET) in Myanmar." International Labour Organization (ILO), Bangkok.

Min Zar Ni. 2018. "Cause and Consequence of International Migration: The Case of Mon State, Myanmar." CESD, Yangon.

MMN. 2016. "Permanently Temporary: Examining the Impact of Social Exclusion on Mekong Migrants." Mekong Migration Network (MMN), Bangkok. 
MOEAF (Myanmar Overseas Employment Agencies Federation). 2016. Code of Conduct for the Members of Myanmar Overseas Employment Federation. MOEAF, Yangon.

MOLIP (Ministry of Labour, Immigration, and Population). 2016. Thematic Report on Migration and Urbanization. Nay Pyi Taw: MOLIP.

Napier-Moore, R. 2017. "Protected or Put in Harm's Way? Bans and Restrictions on Women's Labour Migration in ASEAN Countries." ILO and UN Women.

Natali, Claudia, Euan McDougall, and Sally Stubbington. 2014. "International Migration Policy in Thailand." In Thailand Migration Report 2014, edited by Jerrold W. Huguet, 13-24. Bangkok: United Nations Thematic Working Group on Migration in Thailand.

Oo, Khin Nway. 2016. "Myanmar: Migration and Sustainable Development in the ASEAN and Korea Region." 1st International Experts' Meeting, First Step in Establishing the ASEAN-Korea Migration Network, April 26-27, Manila.

Oo, Khin Nway. 2017. "National Preparatory Meeting on the Role of Countries of Origin in Providing Social Protection to Migrants: Regularization of Myanmar Migrant Abroad, Challenges, Current Initiatives and Future Plans." September 29th, Nay Pyi Taw.

Pattison, C., J. Voss, A. Woodhouse, and M. Zurstrassen. 2016. "A Country on the Move: Migration Networks and Risk Management in Two Regions of Myanmar." World Bank, Yangon.

Robertson, P. 2011. "Trafficking of Fisherman in Thailand." International Organization for Migration, Bangkok.

Saw Htay Wah. 2015. "Do Employers In Myanmar Prefer Workers Who Accumulated Skills In More Advanced Countries? Evidence from a Field Experiment." CESR-Schaeffer Working Paper Series Paper No: 2015-029.

Sein, Kyaw, and Nicholas Farrelly. 2016. "Myanmar's Evolving Relations: The NLD in Government." European Union and Institute for Security \& Development Policy (ISDP), Stockholm.

Soe Lin Aung, 2014. "The Friction of Cartography: On the Politics of Space and Mobility among Migrant Communities in the Thai-Burma Borderlands." Journal of Borderlands Studies 29, 27-45.

Solidarity Center. 2009. "Out of Sight, out of Mind: Human Trafficking and Exploitation of Migrant Fishing Boat Workers in Thailand. Bangkok.

Testaverde, M., H. Moroz, C. H. Hollweg, A. Schmillen. 2017. Migrating to Opportunity: Overcoming Barriers to Labor Mobility in Southeast Asia. World Bank, Washington, DC.

Thanasombat, S. 2004. "Vulnerabilities and Visibility: Thailand's Management of Female Domestic Workers from Burma." Journal of Public and International Affairs 15.

Turnell, S., A. Vicary, and W. Bradford. 2008. "Migrant-Worker Remittances and Burma: An Economic Analysis of Survey Results." In: Skidmore M \& Wilson T (eds.) In Dictatorship, Disorder and Decline in Myanmar. Australian National University E Press, Canberra, Australia. 
UN Women. 2017. "Women Migrant Workers in the ASEAN Economic Community." ASEAN Secretariat Jakarta.

UNCDF. 2017. "Remittances as a Driver of Women's Financial Inclusion in the Mekong Region." UNCDF.

UNTWG (United Nations Working Group on Migration in Thailand). 2019. "Thailand Migration Report 2019," UNTWG, Bangkok.

Verité. 2019. Thailand Bound: An Exploration of Labor Migration Infrastructures in Cambodia, Myanmar, and Lao PDR.

Win, Kywa. 2015. "Feasibility Study on the Establishment of Migrant Welfare Fund Programme in Myanmar." Session 2: Vietnam MWF - Sub-regional meeting to validate findings of the Migration Welfare Fund Feasibility Study conducted in Cambodia, Laos and Myanmar, Vientiane, Lao PDR, 26-27 May 2015.

World Bank. 2018. "Concept Note: Systematic Country Diagnostic 2018." World Bank, Yangon.

World Bank and CESD. 2018. "Rapid Field Assessments in Ayeyarwady, Bago, Magwe, Mandalay, Mon, Kayin, Tanintharyi and Yangon." World Bank, Yangon. 



\title{
CHAPTER 4
}

\section{Conclusions and Policy Recommendations}

\begin{abstract}
- We World Bank's recent Myanmar's Future Jobs report sets forward a comprehensive jobs agenda that addresses the challenges Myanmar must face to create more and better jobs. The policies listed in the jobs agenda range from improvements to fiscal and monetary policies to create a more conducive macro environment for job creation to investments in jobs-friendly global value chains and enhancements to the skills of the workforce. Box I.1, in the Introduction, presents this diversity of policies and outlines their primary objectives.
\end{abstract}

The Active Labor Market Policies (ALMPs) described throughout this report are an important component of the jobs agenda. Many of the policies included in the jobs agenda incorporate elements of ALMPs that address market failures in training, information, and credit. These policies facilitate access to the labor market, particularly for disadvantaged jobseekers. However, ALMPs are just one arrow in the quiver of policies meant to address jobs challenges. And ALMPs sometimes address labor market distortions in the short run, when what is needed is more comprehensive action in the longer run. Still, the breakdowns in the markets for training, information, and credit described throughout the report motivate the urgent need for new policies that can provide access to new and better jobs. 
As Chapter 1 shows, Myanmar is a highly mobile country, however, migrants still face challenges accessing good jobs. Internal and international migrants looking for jobs face challenges that ALMPs are particularly well suited to address. Labor market information and job-matching and -placement services could reduce jobsearch costs and result in more efficient matches, particularly for migrants looking for jobs outside their local areas. Financial support would enable households to invest in income-generating activities at home, and at the same time, explore job opportunities in growing urban centers. And training financed by the government would increase investment in human capital to an efficient level and fill gaps in soft skills training to promote safe migration.

The ability to access good jobs is a key concern of the Government of Myanmar. The Myanmar Sustainable Development Plan (2018-2030), Myanmar's national strategy to inform policies and institutions to drive inclusive and transformational economic growth, incorporates many strategies designed to create good jobs. Its "People and Planet" pillar recognizes the value of harnessing the benefits of work and of protecting the rights of workers, including migrant workers. The strategy proposes the creation of legal, affordable, and secure migration services, the protection of labor rights, and the promotion of safe and secure working environments. Myanmar has launched additional strategies targeted at international migration in particular. The Department of Labor in the Ministry of Labor, Immigration, and Population (MOLIP) developed two five-year strategic plans for international migration that include recommendations to maximize the development benefits of international migration, while also ensuring that it is safe and secure for those working abroad.

The government has created important institutional and policy structures to support access to jobs through ALMPs. Skills training, which offers jobseekers the competencies they need for the labor market, is available from many different ministries. MOLIP oversees the provision of services that help link jobseekers to jobs. Labor Exchange Offices (LEOs), located throughout the country, are the main providers of ALMPs. LEOs register jobseekers and job vacancies and provide job-matching services. The government has also implemented a system to help workers in Myanmar access jobs outside of the country; this system includes a regulated private market for recruitment services, a network of Migrant Resource Centers (MRCs) located within the LEOs to provide information and support to potential migrant workers and their families, and a documentation system to track migrant workers while they are abroad.

However, there are gaps and weaknesses in Myanmar's ALMPs. Chapters 2 and 3 reviewed the training, labor market information, job matching and placement, and financial assistance currently offered by ALMPs in Myanmar, and identified areas that are not functioning well (Table 4.1). They include human and financial resource constraints at LEOs, which prevent more robust service provision; centralizing some key functions, which inhibits flexible decision making at the local level; and a lack of coordination with the groups that could fill some of the gaps in service provision: nongovernmental organizations (NGOs), civil society organizations (CSOs), international development agencies, and the private sector.

Policy reforms are necessary to strengthen Myanmar's ALMPs. The following section presents options for policy reform in the legal and institutional framework for ALMPs and in the areas of training, labor market information, job matching and placement, 
Table 4.1

Gaps and weaknesses in Myanmar's ALMPs

\begin{tabular}{|c|c|c|}
\hline Requirement & Malaysia & No labor attaché \\
\hline $\begin{array}{l}\text { Legal and } \\
\text { institutional } \\
\text { framework }\end{array}$ & $\begin{array}{l}\text { - Human and financial resource } \\
\text { constraints } \\
\text { - Multiple functions performed by LEOs } \\
\text { - Lack of coordination with the private } \\
\text { sector and NGOs, CSOs, and } \\
\text { international development agencies }\end{array}$ & $\begin{array}{l}\text { - Human and financial resource constraints } \\
\text { - Centralized decision-making authority that } \\
\text { inhibits flexible local-level decision making } \\
\text { - The manual system for reviewing demand } \\
\text { letters is inefficient } \\
\text { - Deployment restrictions and requirements } \\
\text { are complicated, time-consuming, and at } \\
\text { times ineffective }\end{array}$ \\
\hline Training & $\begin{array}{l}\text { - Limited offerings that are not } \\
\text { - Ltandardized } \\
\text { - Lack of links to private sector demand } \\
\text { - } \text { financing } \\
\text { - Lack of resources }\end{array}$ & $\begin{array}{l}\text { - Predeparture training is offered in few } \\
\text { - Skcations } \\
\text { - Financial training is limited } \\
\text { - Postarrival orientation is limited }\end{array}$ \\
\hline $\begin{array}{l}\text { Labor market } \\
\text { information }\end{array}$ & $\begin{array}{l}\text { - Limited collection of job vacancies } \\
\text { - Weakness in data collection system } \\
\text { - Lack of public access to survey data } \\
\text { - Lack of dissemination } \\
\text { - Lack of analysis of labor market data }\end{array}$ & $\begin{array}{l}\text { - Significant gaps in labor market information } \\
\text { available to migrants } \\
\text { - Information that is available is difficult to } \\
\text { access and out of date }\end{array}$ \\
\hline $\begin{array}{l}\text { Job matching } \\
\text { and placement }\end{array}$ & $\begin{array}{l}\text { - Human and financial resource } \\
\text { - Jonstraints } \\
\text { - Lab-matching is done manually } \\
\text { recruitment agencies at the local level } \\
\text { - Cumbersome procedures for } \\
\text { jobseeker and vacancy registration }\end{array}$ & $\begin{array}{l}\text { - Enforcement of recruitment oversight } \\
\text { reacts to complaints about incidents that } \\
\text { - have already occurred } \\
\text { - Lack of oversight of private recruitment } \\
\text { - Lachcies at the local level } \\
\text { - Lackinformation about recruitment } \\
\text { - Lack of assistance for migrants after they } \\
\text { - Reintegration policies are largely absent } \\
\text { - Diaspora engagement policies are largely } \\
\text { - Complaints mechanism is largely informal }\end{array}$ \\
\hline $\begin{array}{l}\text { Financial } \\
\text { assistance }\end{array}$ & $\begin{array}{l}\text { - Financial assistance is generally } \\
\text { absent }\end{array}$ & - Financial assistance is generally absent \\
\hline
\end{tabular}

Source: Authors.

and financial services. The chapter concludes with a section outlining a vision for prioritizing these recommendations.

The proposed reforms would improve Myanmar's ALMPs, especially for poorer and less-skilled individuals, and those considering moving for work. As Chapters 2 and 3 showed, private-sector firms provide many ALMP services, from skills training to job matching and placement; however, private-sector firms focus primarily on more highly skilled and wealthier jobseekers, leaving a gap for those with fewer skills or less resources-who frequently search for jobs in limited networks of families and 
friends. The recommendations provided in Table 4.2 would improve ALMPs' ability to reach less-advantaged jobseekers and would make the policies more attractive and accessible to this group. The current clientele of the LEOs, which are the backbone of Myanmar's ALMPs, is a limited group of low- and mid-skilled individuals. Few seem to visit LEOs specifically to learn about internal or international migration.

\section{Rationalizing the legislative and institutional framework supporting migrants and ALMPs}

\begin{abstract}
Improvements to the legislative and institutional framework that supports migrants and ALMPs could make the process of migrating less time-consuming and costly. Table 4.2 summarizes how the legislative and institutional framework could be rationalized. The following section elaborates.
\end{abstract}

1. Rationalize administrative tasks and approvals. Rationalizing administrative tasks and approvals could improve the delivery of ALMPs. LEO staff are burdened with time-consuming administrative tasks related to registering jobseekers and job vacancies and preparing reports. These are largely

Table 4.2

Policy recommendations for the legal and institutional framework

Rationalizing the legislative and institutional framework supporting migrants and ALMPs

Recommendation

Short term

1. Rationalize

administrative tasks

and approvals

2. Continue strengthening bilateral migration relationship

- Use the Thailand MOU as a platform to
- Disseminate widely the information about the Thailand MOU engage Thailand on migration issues

- Reconsider the requirement for all jobseekers to register at LEOs

- Reconsider the requirement that all demand letters must have high level approval$$
\text { approva }
$$$$
\text { chage Thailand on migration issues }
$$

\section{Longer term}
- Business process review and automation

- Work on limiting administrative steps in the Thailand MOU

- Explore the potential for MOUs with other countries

\section{Evaluate the costs and - Carefully consider restrictions on benefits of migration restrictions \\ 4. Strengthen Migration Resource Centers \\ 5. Update the Law Relating to Overseas Employment (LROE) destination countries and on occupations \\ - Raise awareness about MRCs \\ - Provide training to MRC staff \\ - Clarify responsibilities at the national, state and region, and local levels \\ - Fill gaps in the current law, in particular, those related to services for migrants and enforcement}

- Expand the role of MRCs

- Expand the number of MRC 
manual tasks; for example, an officer manually enters a new jobseeker's information on a physical form, then copies the information onto a separate physical form, and then enters the information into a digital information system. Uneven internet access means that the online database entry could take several tries. As will be discussed in detail below, improving the information management system would help eliminate some of these manual steps and automate others. Other efficiency measures could be considered as well; for example, reconsidering the requirement that jobseekers register at a LEO. While the voluntary registration of individuals looking for jobs is an essential role of LEOs, many of these registrations are of individuals who already have jobs, which adds needless work to the already resource-constrained LEO staff without providing any benefits.

Centralizing the decision making at the top levels of MOLIP creates inefficiency in the management of international migration (ILO 2017). Currently, all requests for employment overseas must be approved by the Education, Health, and Human Resources Development Committee, a subcabinetlevel committee chaired by Union Vice President (1) and comprised primarily of very senior officials. This high level of oversight could be reconsidered, and the responsibility shifted to the Migrant Worker Division, which already conducts the day-to-day business of migration management and has developed significant expertise in this area. The Migrant Worker Division reviews the requests for employment (demand letters); if they were also authorized to approve them, the international migration process could be simplified and shortened. Not unlike the LEO's process of registering jobseekers, the process for international jobseekers to migrate abroad is cumbersome and involves some redundant steps. For example, international migrants are required to obtain an overseas jobseeker registration card, in addition to a passport and an Overseas Worker Identification Card (OWIC)

\section{Continue strengthening bilateral} migration relationships. Myanmar and Thailand should continue to work together to reduce the time and cost associated with migrating under their 2016 Memorandum of Understanding (MOU). This MOU represents a continuation of the two countries' efforts to encourage formal migration. Importantly, the MOU has created a platform for Myanmar and Thai authorities to meet regularly to discuss issues related to migration between their two countries. However, the process of migrating via the MOU remains procedurally cumbersome, heavily reliant on recruitment agencies, and time-consuming, and both countries should work to improve it. In particular, the MOU instrument could be used as a tool for transparency and engagement; a plain language version of the contents could be made widely available to people interested in migrating to Thailand for work. A rationalized system for passing documents and information between Myanmar and Thailand could speed up the migration process, lower associated costs, and perhaps even reduce the role of private recruitment agencies. It is important that the MOU continue to be used as a platform for Myanmar and Thailand to engage on emerging issues and concerns related to migration.

Myanmar should also explore the possibility of creating MOUs with other destination countries such as Malaysia. While the negotiating power of countries that send migrants tends to be limited, 
efforts to strengthen coordination with destination countries can have significant benefits to migrants, including lowering their migration costs, expanding access to opportunities for migration, lowering debt and increasing earnings, and improving access to support services (Shrestha, Mobarak, and Sharif 2019) (Box 4.1).

3. Evaluate the costs and benefits of migration restrictions. Migration restrictions and requirements are generally intended to protect migrants, but they can have unintended and adverse consequences. For example, Myanmar's ban on migration for domestic work seems to have led to an increase in the use of illegal brokers and to informal payments facilitating exit from Myanmar, with women bearing the biggest impact and risk (NapierMoore 2017). In other cases, the migration restrictions are not effective. For example, migration to China has increased in recent years despite China not being an official destination country. This unofficial migration channel can undermine the credibility of the formal migration system. Myanmar should carefully weigh the benefits of migration restrictions against their costs, the capacity for implementation, and the potential for unintended consequences. In cases in which restrictions are put in place or remain in effect, they should be communicated carefully to potential migrants, recruitment agencies, and enforcement officials. Myanmar has recently made some progress in this area. MOLIP received approval from the Education, Health, and Human Resources Development Committee to dispatch domestic workers abroad, and is in the process of sending them abroad systematically using Singapore as a pilot country. Via diplomatic channels, MOLIP has proposed to China allowing Myanmar workers to work there legally.

\section{Strengthen Migrant Resource} Centers. Resource constraints suggest that investments in new activities at the Department of Labor would be challenging to execute. However, investing in strengthening MRCs

\section{Box 4.1 Good practices for memorandums of understanding}

Several good practices have been identified when creating and negotiating new MOUs. These include targeting occupations in which destination labor markets face a lack of supply or a rising demand; focusing on the temporary nature of migration, which can reassure policy makers in destination countries about the impacts of immigration on their local workforce; and diversifying migrants across sectors and even economies to ensure that negative shocks to an industry or country do not have a devastating effect on remittances received in the country of origin. For the MOU agreements themselves, it is important that model employment contracts and wage protection measures (such as mechanisms for the automatic deposit of wages into migrants' bank accounts) be included; that public employment services in both sending and receiving countries be involved in implementing the $\mathrm{MOU}$; that gender-specific issues be recognized; that concrete implementation and evaluation measures be listed; and that parties to the MOU be transparent about its contents. MOUs written with these good practices in mind can reduce migration costs by making information available to migrant workers about contracts, working conditions, and rights.

Sources: Wickramasekara 2016; Shrestha, Mobarak, and Sharif 2019. 
would have a significant impact on the functioning of the migration management system at the local level. The role of MRCs could be expanded to include the oversight of both internal and international recruitment agencies; to provide information about job opportunities and recruitment agencies in coordination with the Employment Division and the Migrant Worker Division; and to assist migrants returning home both from inside Myanmar and from abroad. The presence and role of MRCs needs to be advertised broadly, as they are not yet viewed by migrants as providing valuable services. Adding more MRCs to LEOs should also be considered. Locating an MRC at the border with Thailand, a popular crossing point for migrants, could target services to an underserved population. Finally, MRC staff could be given targeted training, which has already been provided in some cases by the ILO and IOM.

5. Update the Law Relating to Overseas Employment (LROE). The LROE is currently undergoing a process of review and revision. An updated LROE could clarify responsibilities in migration management at the national level (for example, the Overseas employment Supervisory Committee (OESC) and its subcommittees) and of state and region and local authorities (for example,

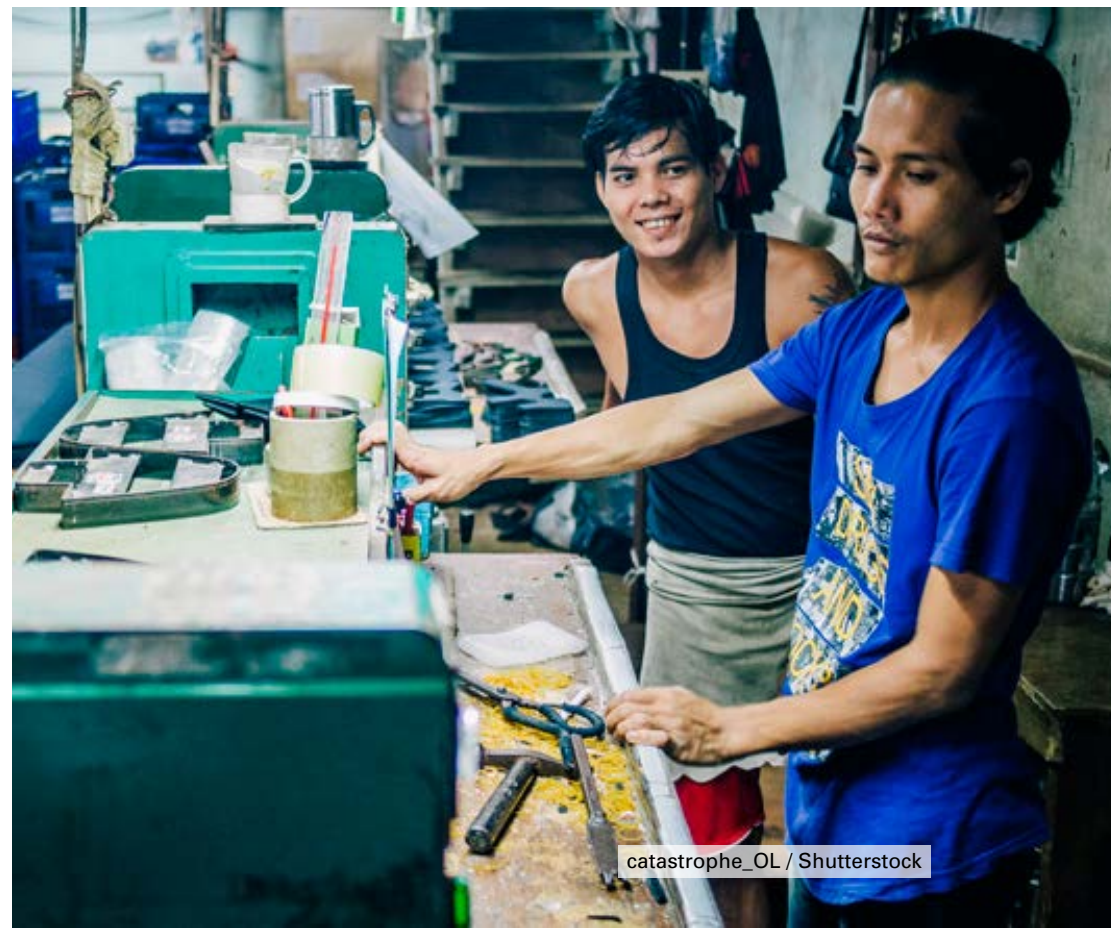

LEOs and state and region offices of the Department of Labor). This would improve the coordination between national and subnational authorities working on issues related to international mobility, avoid overlaps, and exploit synergies. An updated LROE could also fill gaps in the current law that do not reflect the current needs in migration management. These gaps include services for international migrants, such as information provision, reintegration, and legal assistance. An updated law should include provisions related to enforcement, including oversight of overseas employment agencies and a complaints mechanism for migrants.

\section{Transitioning to an employer-driven skills strategy for training}

Providing migrants with the skills that are in demand and filling gaps in the training provided to them before and after departure would expand their access to job opportunities and also help them access those jobs safely. Table 4.3 summarizes how a transition to an employer-driven skills strategy for training could be undertaken. The following section elaborates. 


\section{Policy recommendations for training}

\begin{tabular}{|c|c|c|}
\hline \multicolumn{3}{|c|}{ Transitioning to an employer-driven skills strategy for training } \\
\hline Recommendation & Short term & Longer term \\
\hline $\begin{array}{l}\text { 1. Transition to an } \\
\text { employer-driven skills } \\
\text { strategy }\end{array}$ & $\begin{array}{l}\text { - Enhance cooperation with local } \\
\text { and international employers on the } \\
\text { development and delivery of skills } \\
\text { training }\end{array}$ & $\begin{array}{l}\text { Explore the possibility of } \\
\text { publicly financed training } \\
\text { vouchers for disadvantaged } \\
\text { students }\end{array}$ \\
\hline $\begin{array}{l}\text { 2. Fill gaps in training for } \\
\text { migrants and potential } \\
\text { migrants }\end{array}$ & $\begin{array}{l}\text { - Expand the availability of predeparture } \\
\text { training, including by providing this } \\
\text { training at LEOs and MRCs } \\
\text { - Incorporate financial literacy training } \\
\text { into predeparture training, potentially } \\
\text { in coordination with NGOs, CSOs, and } \\
\text { international development agencies }\end{array}$ & $\begin{array}{l}\text { - Explore the possibility of an } \\
\text { online and mobile phone- } \\
\text { accessible standardized } \\
\text { training module } \\
\text { - Expand the informational } \\
\text { materials that labor attachés } \\
\text { can provide to migrants in } \\
\text { destination countries }\end{array}$ \\
\hline
\end{tabular}

Source: Authors.

1. Transition to an employer-driven skills strategy. Training in Myanmar could be enhanced by aligning it closely with labor market needs. In the short term, this strategy involves coordinating with the private sector. Public training institutions will need to increase and enhance their interactions with employers at home and abroad (these training institutions currently provide training in a limited number of subjects that are not linked to employer demand). This shift will address employers' complaint that an adequately educated and skilled workforce is lacking. One model that facilitates this interaction between training and what is needed by the private sector is skills training councils. The skills training councils would assess the skills needed and coordinate among policy makers, training institutions, and employers to create training modules. High-income and high-capacity countries like Australia, Canada, New Zealand, and the United Kingdom employ such sectoral skills councils. In Australia, training packages are defined by each industry through government- funded Service Skills Organizations. In a setting more similar to Myanmar, China initiated a project that enhanced the training for internal migrants by engaging employers in the development of that training (International Spotlight 1). Training institutions in Pakistan and the Philippines have also identified the skills needed in overseas markets and incorporated them into their programs (International Spotlight 2).

In the longer term, Myanmar could explore using publicly financed vouchers to strengthen the private training market and ensure access to skills training for disadvantaged students. The Myanmar's Future Jobs report recommends increasing the available short-course skills training, including by offering vouchers to vulnerable students. Vouchers would be publicly financed, targeted to disadvantaged or vulnerable individuals, and usable at private training institutions. Such a system could strengthen the existing private market for training in Myanmar, and it could improve the quality of 


\section{International Spotlight 1: Improving access to training for in-demand skills in China}

Despite China's extensive rural-to-urban migration, rural migrants often lacked the skills sought by urban employers because of their limited access to training services. Urban employers were disinclined to train these new employees because of high turnover. The World Bankfinanced Rural Migrant Skills Development and Employment Project linked employment services directly to training. The project's training intervention had four components. The first component provided equipment for training centers and schools to help them deliver the training for in-demand skills. This included exploring ways to use public training platforms to expand training by private providers, and to use mobile training to provide short-term, modular training to isolated communities. The second component ascertained the learning needs of migrant workers and the skills needs of industry so that they could create a competencybased curriculum, prepare instructional materials, and train instructors. Guidelines for public training platforms and manager training were also developed. The third component worked on improving accreditation standards for provincial training institutions and on strengthening the policies related to public training subsidies for migrants. Those subsidies received government funding. Finally, information on training opportunities was created for migrants.

The project had several important characteristics. First, the project adapted training modalities to suit the needs of migrant workers who cannot afford the time or cost of lengthy trainings. The curriculum was developed in modules, and delivery included mobile training to reach rural areas. Second, the project sought partnerships between the public and private sector. In one province, a committee comprised of schools and local enterprises met twice a year to create school development plans. An annual workshop was held with large and mid-sized enterprises to identify the high-tech skills that were in demand. Third, the flexibility of the project allowed for certain implementation areas to be emphasized differently; for example, one province focused heavily on links between the public and private sector, while another focused on delivering training to hard-to-reach rural areas.

Sources: Wickramasekara 2016; Shrestha, Mobarak, and Sharif 2019.

\section{International Spotlight 2: Adapting training programs in Pakistan and the Philippines to the skills needed abroad}

In Pakistan, technical and vocational education and training (TVET) institutions are increasingly focused on identifying the skills demanded by overseas employers and adapting their training accordingly (GIZ and ILO 2016). The Ministry of Federal Education and Professional Training's skills strategy emphasizes the importance of developing skills aligned with the demands of overseas employers. For instance, the Punjab Skills Development Fund (PSDF) (a nonprofit set up with the Government of Punjab and the Department for International Development UK) and the Punjab TVET Authority have both assessed the skills demand in Gulf Cooperation Countries (GCC) and tailored their programs to train overseas workers in those skills. The 
Punjab TVET Authority created a unit to place workers abroad in hospitality, mechanical, and other jobs, and has held meetings with representatives from Saudi Arabia and the United Arab Emirates. PSDF has created partnerships with overseas employers to help place graduates directly into employment abroad, and they are looking to contract an overseas employment agency to provide emigration services to their graduates. Likewise in the Philippines, the Technical Education and Skills Development Authority (TESDA) pays close attention to the skills demanded by overseas employers. Prior to departure, migrants must undergo a skills test administered by TESDA demonstrating their skills qualification. TESDA seeks to cultivate professional and personal relationships abroad.

Sources: Wickramasekara 2016; Shrestha, Mobarak, and Sharif 2019.

training courses; for example, students would be able to use the voucher to choose which training they receive, which would encourage competition and ensure equity in access. Such a system would still require regulation and strong public oversight of the training market.

\section{Fill gaps in training for migrants and} potential migrants. Myanmar needs to fill several gaps in the training provided to migrants and potential migrants. First, predeparture training could be made more widely accessible. Myanmar makes predeparture orientation available to everyone who wishes to take it, but it is not required for migrants to Thailand. Additionally, predeparture training is only available in Yangon and Mandalay. While this reflects the fact that most (formal) international migrants depart from Yangon, information from predeparture orientation would be more useful to migrants earlier in their decision-making process, that is, before they reach Yangon or Mandalay, whereas now it often occurs just before migrants leave for their jobs abroad. And while predeparture training is open to anyone, those not close to Yangon or Mandalay and those migrating informally may not be able to access it. Mandating that MRCs and LEOs provide predeparture orientation, even in a limited form, could expand access to information about migration procedures, including to migrants to Thailand and to migrants using informal migration channels. Also, the Department of Labor could leverage technology to make a standardized training module available to anyone curious about migration. This training could be freely available online and accessible via mobile devices. Predeparture orientation programming in the Philippines offers several options that are relevant for Myanmar (International Spotlight 3). Second, financial literacy should be emphasized in predeparture training. As described in Chapter 3, a lack of financial literacy and access to affordable credit constrain the ability of returning migrants to invest their savings profitably. A financial literacy program for migrants in Indonesia had some positive impacts, including increased financial planning, budgeting, and savings (International Spotlight 4). In Malaysia, a financial literacy program was developed that seeks to increase the use of formal remittance channels (International Spotlight 5). Finally, materials like those developed for predeparture orientation could be created for Myanmar's labor attachés in destination countries, as is done in Indonesia and in the Philippines (International Spotlight 6). Although these attachés already have many responsibilities, providing migrants 
with simple materials that list the key information about the country in which they are working would help inform workers' transition to employment abroad.
The Department of Labor could work closely with NGOs, CSOs, international development agencies, and the private sector to help fill training gaps. As Chapters 2 and 3 describe, many of these agencies

\section{International Spotlight 3: Predeparture orientation in the Philippines}

The Philippines offers three types of orientation programs to prepare temporary migrants for employment abroad. The Pre-Employment Orientation Seminar (PEOS) is designed to help domestic, and professional and skilled Filipino workers decide whether they wish to migrate. To this end, the PEOS provides information about the job search and recruitment process, including general information about working overseas, job-search information, details about illegal recruitment, information about allowable fees and the minimum provisions of the employment contract, and information about host countries. The PEOS provides profiles of the countries workers migrate to, and for domestic workers, they offer the following modules:

- Module 1: General information about working abroad

- Module 2: How to apply to work abroad as a domestic worker

- Module 3: How to avoid illegal recruitment agencies

- Module 4: What can be expected from employers and recruitment agencies, including fees

- Module 5: The standard employment contract for overseas workers

- Module 6: Health information

- Module 7: Information on the Philippines Overseas Employment Agency

Previously, the orientation seminar was voluntary and offered at Philippines Overseas Employment Administration (POEA) and Department of Labor and Employment (DOLE) regional offices (IOM and Scalabrini 2013). Now the PEOS is mandatory, but it can be taken online for free (POEA 2016).

The Pre-Departure Orientation Seminar (PDOS) is a mandatory six-hour course for migrants who have obtained employment abroad. This seminar was organized by the Overseas Workers Welfare Administration (OWWA), the primary agency responsible for overseeing the welfare of overseas Filipino workers and their dependents. The seminar is designed to help Filipino workers adjust to their working and living conditions abroad, particularly in the short term. The seminar includes modules on working overseas, including about the culture and a code of discipline; the employment contract and what to do in case of violations; programs and services available to migrant workers in the Philippines and in the host country; and tips on health, financial planning, and travel. Accredited recruitment agencies, NGOs, and the OWWA, and its local offices, provide the course for free.

Finally, domestic workers must attend the Comprehensive Pre-departure Education Program, which was implemented in 2009. The program is either a four- or a six-day course that provides training in language, culture, and stress management. Accredited NGOs provide the training during the first day, while OWWA provides the additional components. 
Several relevant practices stand out in the Philippines' predeparture orientation programs, including the involvement of local government partners, the NGOs who provide a rights perspective, and delivery at the local level (Asis and Agunias 2012). Lessons can also be learned from the weaknesses in the Philippines' approach: Accredited providers at times have diverged from the specified content and methodology, provided certificates even when the orientation seminar was not attended, imposed fees, or held shortened sessions (Anchustegui 2010). There have also been complaints that the sessions have been used to promote remittance and insurance products (Ambito and Banzon 2011; Anchustegui 2010; DOLE 2014).

Source: Authors.

\section{International Spotlight 4: Providing financial literacy education in Indonesia}

Indonesia created the Pilot Program on Financial Literacy Education for Migrant Workers and Their Families to test whether financial literacy training could improve how remittances are used. The program was developed by the Government of Indonesia and the World Bank; it was delivered to female migrant workers and their families in the Greater Malang area and the Blitar District of East Java Province.

The training was conducted at a facility managed by the Malang Manpower and Transmigration Office and at the offices of recruitment agencies. Transportation for migrant workers was coordinated by recruitment agencies, while the Regional Economic Development Institute (REDI), a local research institution, worked with recruitment agencies to invite family members to the course. A transportation allowance and one night of accommodation were provided to the family members. Migrants and their families were trained separately, because there was a different curriculum for each group. For migrants, the training was 2 days, 9 hours each day, and for their families, the training was 2 days, 4 hours each day. The trainers were from REDI. These are the 6 modules for the migrant workers:

- Module 1: Financial management, including financial planning, budgeting, and discussing the use of money with family members prior to departure

- Module 2: Banking services, including the use of bank accounts and ATMs

- Module 3: Savings, including the importance of savings and different uses

- Module 4: Debt management, including loan options and how to calculate interest rates

- Module 5: Remittances, including remittance channels and understanding exchange rates

- Module 6: Insurance, including understanding the insurance that Indonesia provides to migrant workers 
There were 5 modules for the families of migrant workers:

- Module 1: Financial planning and management

- Module 2: Savings

- Module 3: Debt management

- Module 4: Sending and receiving remittances

- Module 5: Insurance

The curriculum was participatory and interactive, and it included discussion, group games, and assignments. The training was also practical; for example, participants were instructed on how to use an ATM machine and how to prepare a budget. A financial booklet with budgeting templates was provided to participants.

The financial literacy program had positive impacts on participant households, especially when the entire household participated. For instance, the training led to more financial planning and budgeting, and to more savings, and there was less reliance on loans when both the family members and the migrant received the course. Impacts were smaller when only the family members were trained, and not significant when only the migrant was trained.

Source: Authors, based on Doi, McKenzie, and Zia (2014) and its appendix

\section{International Spotlight 5: Encouraging formal remittances in Malaysia and Indonesia}

In Johor Bahru, the capital of the Malaysian state of Johor, the World Bank partnered with Malaysia's central bank Bank Negara Malaysia on Project Greenback 2.0, a project that encourages the use of formal remittance channels. ${ }^{1}$ Migrant workers in Johor Bahru were first surveyed about their remittance behavior and their economic and social profiles. In particular, the survey was aimed at assessing their level of financial inclusion, their methods for remitting money to their countries of origin, and their use of information and communication technologies. The project then sought to engage migrant workers, SMEs, chambers of commerce, and other stakeholders through education and outreach programs that encourage the use of formal remittance channels. Outreach efforts include remittance fairs at plantations and mobile promotions through "Greenback-on-wheels." The project also incorporates awareness campaigns for Pick Remit, a mobile application developed by the World Bank that allows users to compare remittance services based on host country, country of origin, and amount to be remitted. The application lists available remittance service providers and their location. Importantly, Greenback 2.0 focuses on access to financial services for all migrants, regardless of their status as formal or informal. 
Greenback 2.0 has also been launched in Lombok Timur in Indonesia-the origin of many of the migrants in Johor Bahru. The project was initiated by the World Bank and is being implemented by Indonesia's Central Bank, the Indonesia Financial Service Authority, the Agency for the Placement and Protection of Indonesian Migrant Workers, and local authorities. Like the project in Johor Bahru, in Indonesia, Greenback 2.0 will work to increase the efficiency of the remittance market by providing financial education and expanding access to the financial system. The financial awareness campaign includes these goals:

- Establishing subvillage information points and printed materials to disseminate information on financial topics

- Providing practical financial tips to villagers via a weekly SMS text message, and

- Disseminating information through in-person meetings, social media, and comedy performances and films produced by village youth.

Source: Authors.

\section{International Spotlight 6: Delivering post-arrival orientation to migrant workers from the Philippines and Indonesia}

The Philippines' Post-arrival Orientation Seminar (PAOS) includes instruction on migrants' rights and responsibilities, information on the assistance available at diplomatic missions, and details about community activities. The seminars are conducted by the Philippines Overseas Labor Offices (POLOs), which manage migration matters from abroad. The seminars are conducted once every two months in Singapore, and they are not mandatory.

For migrants to the Republic of Korea, a group of departing migrants is assigned a "team leader" who coordinates with the POLO and with the Korean authorities. The POLO conducts a 45-60-minute post-arrival seminar that includes information on immigration laws, the services available to migrants, plans in case of emergency, and reintegration preparedness and returnee support programs. Financial literacy programs are also available to migrants and are coordinated through Philippine banks and community organizations.

Indonesia's Welcoming Programme provides information to migrants about their rights, the culture of the destination country, services and assistance available to them, and appropriate employer expectations. This program is available to migrant workers in Hong Kong SAR, China, and in Taiwan, China. The orientation is provided by the Indonesian Consulate in Hong Kong SAR, China, and by the Indonesian Chamber of Commerce and Industry in Taiwan, China. Recruitment agencies are supposed to ensure that migrant workers attend this mandatory orientation. The Indonesian Consulate in Hong Kong SAR, China, also offers classes in cooking, makeup, hairdressing, and language, and in entrepreneurship for when migrants return home.

Source: Authors based on ILO (2015b). 
have programs targeted to migrants that offer information about the migration process and skills training, and some of them help link migrants and jobseekers to employment. The Department of Labor could partner more closely with these groups to provide information about updated migration procedures, emphasize the need for financial literacy training, and even develop resources for migrants and potential migrants. Indeed, innovative digital resources are being developed that could be improved through closer engagement with the Department of Labor and other government agencies. In its work with recruitment agencies, the Department of Labor should ensure that thorough and accurate information is being given to the jobseekers they recruit.

\section{Expanding access to labor market information}

Improved coordination with the private sector and with NGOs, CSOs, and international development agencies could enhance both the collection and dissemination of labor market information in the short run. Table 4.4 summarizes how access to labor market information could be expanded. The following section elaborates.

\section{Table 4.4}

\section{Policy recommendations for labor market information}

\begin{tabular}{|c|c|c|}
\hline \multicolumn{3}{|c|}{ Expanding access to labor market information } \\
\hline Recommendation & Short term & Longer term \\
\hline $\begin{array}{l}\text { 1. Fill gaps in labor } \\
\text { market information }\end{array}$ & $\begin{array}{l}\text { - Create voluntary mechanism for reporting } \\
\text { vacancies through partnerships with } \\
\text { employers, recruitment agencies, and } \\
\text { online job portals } \\
\text { - Encourage LEOs to reach out to employers } \\
\text { to uncover vacancies and skills needs }\end{array}$ & $\begin{array}{l}\text { - Conduct surveys of migrants at } \\
\text { different stages of the migration } \\
\text { cycle }\end{array}$ \\
\hline $\begin{array}{l}\text { 2. Improve the } \\
\text { dissemination } \\
\text { of labor market } \\
\text { information }\end{array}$ & $\begin{array}{l}\text { - Encourage LEO officers to provide } \\
\text { information about job openings in other } \\
\text { locations to jobseekers } \\
\text { - Post overseas job openings from demand } \\
\text { letters on MyanmarJob.gov.mm/ } \\
\text { - Make administrative data available to } \\
\text { CSOs, NGOs, international development } \\
\text { agencies, and the private sector } \\
\text { - Make the Labor Force Survey publicly } \\
\text { available } \\
\text { - Create clear information bulletins about } \\
\text { deployment restrictions and requirements } \\
\text { and publicize them widely }\end{array}$ & $\begin{array}{l}\text { - Use an enhanced information } \\
\text { system that enables jobseekers } \\
\text { to access information about job } \\
\text { openings in any location from } \\
\text { any LEO } \\
\text { - Develop a devoted portal for } \\
\text { listing overseas job openings }\end{array}$ \\
\hline $\begin{array}{l}\text { 3. Enhance the } \\
\text { analysis of labor } \\
\text { market information }\end{array}$ & & $\begin{array}{l}\text { Expand the labor market infor- } \\
\text { mation analysis function of the } \\
\text { Department of Labor and LEOs }\end{array}$ \\
\hline
\end{tabular}


1. Fill gaps in labor market information. Research from around the world shows the importance of providing information about the labor market to jobseekers, students, and other labor market stakeholders so that they can make decisions about their education, training, and jobs (International Spotlight 7). In Myanmar, there are gaps in the information pipeline-specifically, about job vacancies and in-demand skills. To fill these gaps, the Department of Labor should enhance their connection to employers. Instead of requiring employers to register job vacancies, the Department of Labor through its LEOs could partner with employers and private recruitment agencies to create a mechanism for reporting job vacancies that would offer a holistic picture of labor demand. This could improve the labor market information available to jobseekers at a low cost. Given their presence at the local level, LEOs could reach out to employers to understand their current needs. The Department of Labor could supplement these efforts by also partnering with online job search websites. These websites typically target more highly skilled jobseekers, so they are not in competition with employment services provided by the Department to less-skilled workers. This makes an arrangement to share jobseeker and vacancy registrations mutually beneficial to the job search websites (where job postings are seen by more people) and to the Department of Labor (which gets access to more job openings).

Additional data collection could also be initiated. In particular, surveys of migrants at different stages of the migration cycle could help identify the factors that drive up migration costs and that put migrants at risk. These surveys could also help identify important channels of impact for migration such as through remittances.

2. Improve the dissemination of labor market information. The dissemination of labor market information in Myanmar is currently insufficient. Jobseekers do not have access to the information they need to find jobs, particularly in other locations. One solution is to ensure that jobseekers at a given LEO location can access job vacancy advertisements at all other LEOs-which could be facilitated by a new information technology system. LEO officers are already able to access vacancies in other locations, and should be encouraged to highlight those job openings to jobseekers. Potential international migrants typically learn about overseas vacancies from overseas employment agencies. Ideally, vacancies collected from demand letters registered by overseas employment agencies would be posted to MyanmarJob.gov.mm/ and disseminated at LEOs and MRCs, but that is not currently done. In the longer run, Myanmar could consider developing a devoted portal for overseas job openings, modeled on the portal created in the Philippines (International Spotlight 8). The Department of Labor could also enlist the support of NGOs, CSOs, international development agencies, and the private sector to disseminate labor market information by making their vacancy and jobseeker registration data available through partnerships with these groups, who could then use the data to inform program design and even develop their own dissemination tools. Data in the Labor Force Survey could also be made available. Finally, there is little information about deployment restrictions and requirements available to potential migrants. The Department of Labor could communicate this information more widely at LEOs and MRCs via information bulletins 


\section{International Spotlight 7: Evidence from around the world on the importance of labor market information}

\begin{tabular}{|c|c|}
\hline Paper & Finding \\
\hline $\begin{array}{l}\text { Dammert, Galdo, and } \\
\text { Galdo (2015) }\end{array}$ & $\begin{array}{l}\text { - In Peru labor market intermediation through SMS text messages } \\
\text { informing jobseekers about job opportunities matching their profile had a } \\
\text { positive impact on employment. }\end{array}$ \\
\hline Beam (2016) & $\begin{array}{l}\text { - A job fair in the Philippines did not lead to jobs for the attendees, but it } \\
\text { did increase formal sector employment and job searches in other areas. }\end{array}$ \\
\hline Abebe et al. (2017) & $\begin{array}{l}\text { - A job fair in Ethiopia did not result in jobs, likely because of mismatched } \\
\text { expectations about wages, firm requirements, and jobseeker quality. The } \\
\text { job fair did lead low-skilled workers to update their expectations, increase } \\
\text { their job searches, and ultimately improve their employment outcomes. }\end{array}$ \\
\hline $\begin{array}{l}\text { Fuller, Lightfoot, and } \\
\text { Kamnuansilpa (1985) }\end{array}$ & $\begin{array}{l}\text { - Providing information about job opportunities and sponsoring job } \\
\text { searches increased migration from villages to urban areas in the same } \\
\text { region of Thailand. }\end{array}$ \\
\hline Jensen (2010) & $\begin{array}{l}\text { - Eighth-grade boys in the Dominican Republic have low expectations } \\
\text { of the benefits of secondary school. Providing these students with data } \\
\text { on the returns to education increased the years of school completed, } \\
\text { especially for the least poor students; this information had no effect on } \\
\text { the poorest. }\end{array}$ \\
\hline Nguyen (2008) & $\begin{array}{l}\text { - Providing information to parents and children on the returns to education } \\
\text { in Madagascar reduced the gap in expectations about those returns, } \\
\text { improved test scores, and increased attendance. }\end{array}$ \\
\hline $\begin{array}{l}\text { Wiswall and Zafar } \\
\text { (2015) }\end{array}$ & $\begin{array}{l}\text { - Even high-ability college students in the United States have little } \\
\text { knowledge about job earnings. When given publicly available information } \\
\text { about earnings, students revised their expectations, especially when } \\
\text { information was more specific, and they also altered their intended } \\
\text { majors. }\end{array}$ \\
\hline
\end{tabular}

Source: World Bank (2019).

and via partnerships with NGOs, CSO, international development agencies, and the private sector (particularly, recruitment agencies). For this information to be effective, the communication of restrictions and requirements must be clear and easy to understand.

\section{Enhance the analysis of labor market information. The Department of Labor}

and the LEOs engage in data collection and tracking, but they do not analyze the information they collect. In the long term, the labor market information analysis function should be expanded. This would allow insights to be made at the Union and local levels about labor market trends and skills needs. Expanding this function would require investments in capacity building. 


\title{
International Spotlight 8: Improving access to labor market information for migrants in the Philippines
}

The government of the Philippines created a small-scale initiative to improve jobseekers' access to labor market information. WorkAbroad.ph is an online job portal where jobseekers can search for employment overseas. ${ }^{2}$ The job postings on the website are reviewed and then posted by recruitment agencies licensed by the Philippines Overseas Employment Administration. Jobseekers can create an account on WorkAbroad.ph and post an online resume that recruitment agencies can view. The website also includes a skills and education matching system. This approach has shown some effectiveness in the Philippines. A recent study found that providing access to a website matching jobseekers to overseas employment opportunities induced additional overseas job searches, but no additional overseas migration (Beam, McKenzie, and Yang 2016).

Source: Authors.

\section{Developing targeted job-matching and -placement services}

\begin{abstract}
Targeting job-matching and -placement likely to benefit from them. Table 4.5 services to low-skilled and disadvantaged summarizes actions to develop targeted workers would focus these services on job-matching and-placement services. The the underserved individuals who are most following section elaborates.
\end{abstract}

\section{Table 4.5}

\section{Policy recommendations for job matching and placement}

\begin{tabular}{|c|c|c|}
\hline \multicolumn{3}{|c|}{ Developing targeted job-matching and -placement services } \\
\hline Recommendation & Short term & Longer term \\
\hline $\begin{array}{l}\text { 1. Invest in an } \\
\text { information } \\
\text { management } \\
\text { system }\end{array}$ & $\begin{array}{l}\text { - Address technical gaps in data quality, } \\
\text { integrity, and security in the existing online } \\
\text { employment services system (modest } \\
\text { option) } \\
\text { - Customize the existing online employment } \\
\text { services system to replace all offline } \\
\text { functions (ambitious option) }\end{array}$ & $\begin{array}{l}\text { - Establish an integrated platform } \\
\text { that supports end-to-end } \\
\text { automation of employment and } \\
\text { migration services }\end{array}$ \\
\hline $\begin{array}{l}\text { 2. Explore new } \\
\text { technologically } \\
\text { informed services } \\
\text { delivery channels }\end{array}$ & & $\begin{array}{l}\text { Develop applications to send } \\
\text { information to and receive } \\
\text { messages from registered } \\
\text { workers automatically }\end{array}$ \\
\hline
\end{tabular}

2 See https://www.workabroad.ph/index.php (last accessed January 14, 2019) 


\section{Developing targeted job-matching and -placement services}

Recommendation

3. Target jobmatching and -placement services to low-skilled and disadvantaged jobseekers

4. Improve the oversight of overseas employment agencies

5. Strengthen the assistance provided to migrant workers while they are abroad

6. Explore diaspora engagement policies

\section{Short term}

- Target job-matching and -placement services to low-skilled and disadvantaged jobseekers

\section{Longer term}

- Explore the creation of a competitive market for providing employment services to low-skilled and disadvantaged jobseekers
- Encourage adoption and use of MOEAF's Code of Conduct rating system by providing data, publishing the ratings, and providing incentives, such as priority processing or relaxed scrutiny for demand letters

Source: Authors

1. Invest in an information management system. A key component of targeted job-matching and -placement services is an information management system that can efficiently collect, process, and disseminate information about jobseekers and job vacancies. The Department of Labor could improve the efficiency and delivery of its services by investing in an updated information management system that would provide employment services to both jobseekers within Myanmar and migrants looking for work abroad. The information systems used to collect data on jobseekers and vacancies in Myanmar, and for tracking demand letters and international migrants, suffer from significant weaknesses that create inefficiencies.
Paper-based record-keeping remains common in Myanmar, despite the existence of an online system, and the existing online system is only used for data digitization. The dissemination of labor market information, job matching and placement, and tracking of jobseekers and migrants are all done manually. Jobseekers and employers must perform in person many of the functions related to registering with LEOs.

An assessment of the management information system done for this report found technical gaps in data quality and integrity, data security, system flexibility, and interoperability and scalability (Joshi 2018). The assessment offered practical 
recommendations for an integrated management information system that (1) effectively provides end-to-end automation of all program functions within the Department of Labor, and (2) ensures information standardization and effective administration and monitoring across all programs using a common IT platform. Components of the system could include online jobseeker registration and a mobile application, as well as the creation of a database to collect demand letters digitally in accordance with the Government of Myanmar's emphasis on e-government. The assessment also defined short- and longer-term objectives.

The short-term objective would be to address the most critical technical gaps that could yield quick improvements; for example, investments in the IT system could result in a range of changes from modest to more ambitious. The more modest changes would involve quick fixes to the Department of Labor's existing offline (manual) system. This option would fine-tune the existing system to address some of the technical gaps in data quality, integrity, and security, and ensure that data entry by LEOs is of good quality, usable for data analysis, and viable for future data migration. The more ambitious changes would involve customizing the existing online system to replace all of the functionalities of the offline system. This would bring all functions of the LEOs online. Additional security measures would also be implemented.

The longer-term objective would be to establish an integrated management information platform that supports end-to-end automation of employment and migration services. This integrated platform would not only support information standardization, it would also enable the Department of Labor to better administer and monitor all of its services through a single unified platform (Figure 4.1). The design framework would put a priority on interoperability to facilitate data sharing with external systems via a secure datasharing protocol. The scalable design would ensure that the platform can be further customized and enhanced when new business requirements arise, new programs are introduced, and existing programs are suspended or modified. The design framework would include the following key elements:

- Tablet- or smartphone-based data collection. LEO staff would collect data using tablets or smartphones that have seamless integration with the platform, thereby enabling them to synchronize the data in almost realtime, depending on the availability of the internet or $4 \mathrm{G}$. Such functionality could be made available in addition to traditional data entry using desktop and laptop computers.

- Centralized and integrated platform. Employment and migration services could have business processes that operate independently but are still integrated into one centralized platform for management by the Department of Labor.

- Data exchange protocol. The platform would have functionalities that would enable data exchange with external databases, including privatesector ones through a secure and reliable channel, and allow the Department to validate the uniqueness, accuracy, and completeness of an individual's account. For instance, the exchange of data with the SmartCard database (a SmartCard is issued to every formal migrant worker) could happen automatically.

- End user access. The platform would operate using a secure internet 
connection in a centralized environment; in other words, it would operate using a unified URL (e.g. https://dol.gov.mm) for all functions related to employment and migration services. An authorized user with a valid login and password could login through this URL and perform transactions in a secure manner.

- Data security. Data security would rely on encrypted data transmission and the ability to perform data audits on all user transactions.

- Backup. Backup provisioning would be automatic to ensure business continuity.

- Business intelligence. Business intelligence functionality would be incorporated to generate reports and data analysis for improved program administration and monitoring. This tool would enhance the ability of Department management to make evidence-based decisions. Reporting outputs that could be generated through the information system include real-time, reliable reports on jobseekers, job vacancies, job matches, demand letters, migrant workers abroad, and numerous other items of interest.

The sustainability of such an integrated information system would require the Department to develop its own technical capacity to maintain the IT infrastructure, but it will likely still need to rely on the private sector to provide some IT-related operations.

An enhanced information system could improve the efficiency and quality of employment services in Myanmar. Such an integrated platform would transfer

Figure 4.1

Proposed design framework for an integrated information system platform

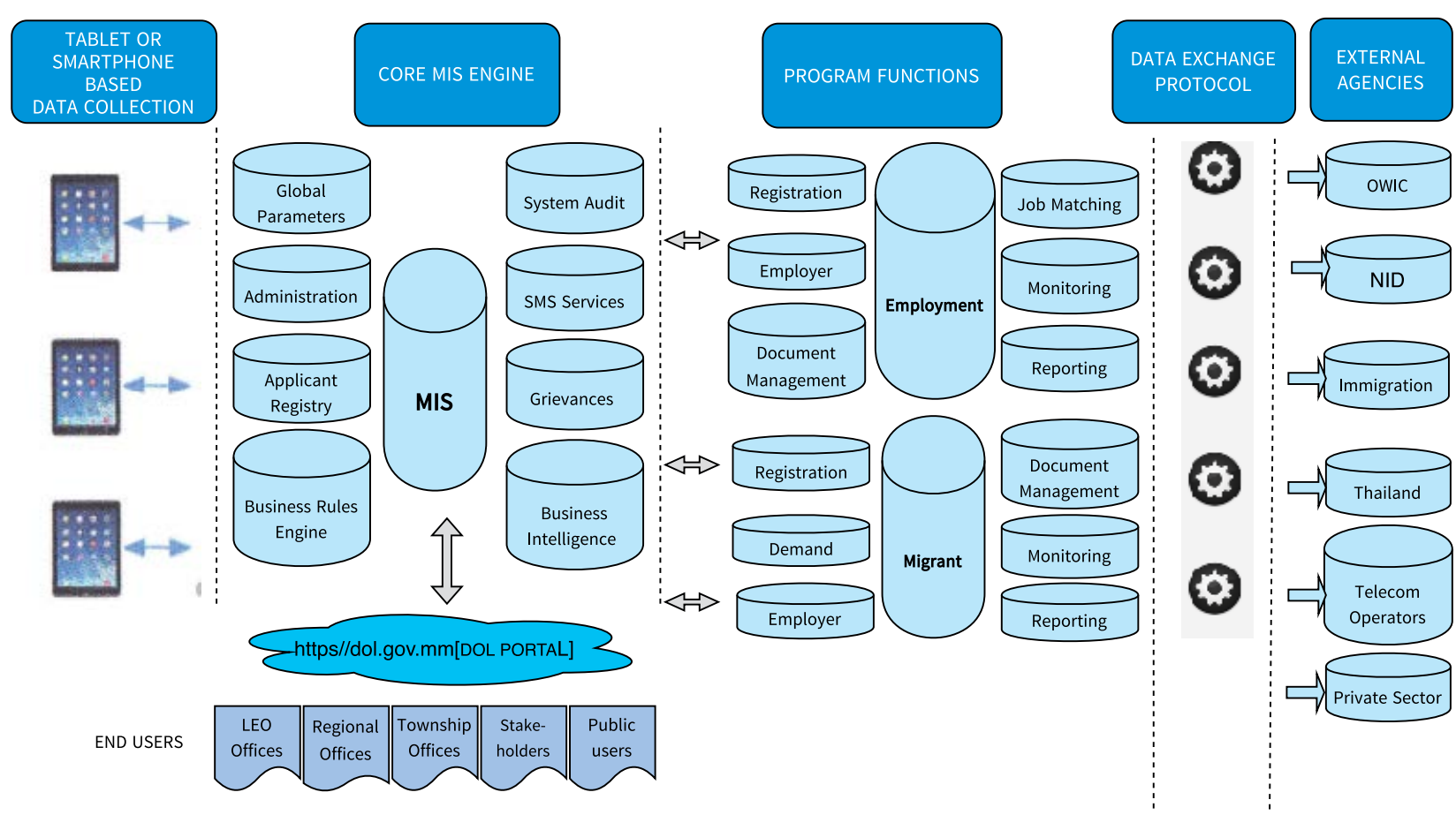


many of the functions now done manually to an automatic system, saving valuable time and resources. The platform would also improve the services offered by the Department of Labor. Jobseekers, job vacancies, and migrants could be tracked more easily, allowing performance and the effectiveness of employment services to be assessed. Labor market information could be generated from the administrative data collected. Finally, the process of job matching and placement could be automated.

This vision of an integrated information system is consistent with the Department of Labor's priority to create an information system that is user-friendly, effective, and efficient for jobseekers and employers for job matching. One of the priorities of the Migration Division is to have a digital database of demand letters, in accordance with the Government of Myanmar's emphasis on e-government.

\section{Explore new technologically} informed service delivery channels. The type of integrated and scalable platform described above would open doors for more innovative ways to use technology to deliver services, including the labor market information described in the previous section. For instance, the platform could be integrated with an SMS gateway to trigger text messages to registered workers. Likewise, a Department of Labor mobile application could be developed that would allow the Department to send messages to registered workers and receive them from registered workers automatically. Such innovations would also enable the analysis of worker behavior to further tailor and improve services. These tools could be used to improve access to information about the labor market, labor rights and the rights of migrants, internal and overseas recruitment agencies, and remittances. Several examples of these applications have already been launched in Myanmar. They include the Issara Institute's Golden Dreams application, a Myanmarlanguage smartphone application for learning and exchanging information, reviews, ratings, comments, and advice about employers, recruitment agencies, and service providers in migrant source and destination countries. The application is designed primarily for workers considering jobs abroad and their parents. Golden Dreams' main features are (1) alerts and notifications, such as about changes in regulations; (2) news related to migrant workers; (3) a guide on workers' rights, including information about how to live and work in Thailand (providing information about other destination countries is being considered); (4) a polling feature; (5) searchable information on all licensed overseas employment agencies recruiting to Thailand and their local representatives, along with the ability to see and provide user-generated reviews; (6) searchable information on employers in Thailand; and (7) information on the providers of services to migrants, such as training and job matching.

Another prominent example is the GOOD chatbot-a collaboration between the Aung Myin Hmu project and MyJobsthat provides employment information and job search capabilities to low-skilled garment sector workers to reduce their reliance on labor brokers and to reduce employment gaps. The GOOD chatbot provides information about job searching and recommends a small number of job openings via Facebook Messenger. The chatbot obtains basic information about the jobseeker (for example, name, hometown, age, gender) and asks them whether they are expecting a salary of more than MMK300,000. Because the tool is designed for less-skilled workers, 
the expectation of a higher salary would direct them to the MyJobs website. If their expectations are within the MMK300,000 range, they are shown a limited number of jobs, asked whether they are interested in them, and provided information about the Aung Myin Hmu training center for garment sector workers. MyJobs vets the jobs by visiting with employers and asking them about worker compensation, overtime, paid leave, employment contracts, working hours, and their awareness of labor regulations.

Other examples include SMART Myanmar's Android apps to provide information to garment sector workers; Shwe Job's use of interactive stories and voiceovers to educate about labor laws and occupational safety and health in garment factories; and Satyone Superstar's use of a game to instruct users about labor laws and occupational safety and health (see Chapter 2 for more details about these platforms).

\section{Target job-matching and -placement} services to low-skilled and disadvantaged jobseekers. There is a relatively robust private sector of agencies recruiting workers for employment inside the country. However, these firms are generally focused on mid- and high-skilled workers. Only a single firm seems to target low-skilled workers for domestic employment. This failure of the market to provide job-matching and -placement services to lower-skilled workers necessitates government intervention, because these jobseekers instead rely on social networks, which may have limited or skewed information about available jobs, and informal brokers who are potentially exploitative.

Although right now LEOs primarily serve jobseekers who have already found a job and are registering at the LEO as a condition of their employment, LEOs could target their resources to provide services to less-skilled jobseekers, and particularly poor and vulnerable groups who have few tools to find jobs on their own. This focus on particular types of jobseekers has proven effective in other countries like China, where employment services have been targeted to rural areas and to internal migrants (International Spotlight 9), and in India where these services have been targeted to women in rural areas (International Spotlight 10). Prioritizing low-skilled or disadvantaged jobseekers for employment services requires taking into account the resource constraints facing LEOs. An improved information management system would improve the delivery of job-matching and -placement services to this core clientele.

A longer-term model for delivery of job-matching and -placement services could include providing public financing to private sector firms to match target groups of jobseekers with employment. This would leverage the expertise of the private sector and provide services to disadvantaged or underserved groups, such as the less skilled. The services provided would vary, but a provider might offer skills training, resume and job search support, and post-placement follow-up support. Such a market, in which private-sector firms compete to provide employment services financed at least in part by public funds, requires more sophisticated systems for managing contractors and tracking results-although quite advanced, Australia's approach provides the key components of such a system (International Spotlight 11).

4. Improve the oversight of overseas employmentagencies. The Department of Labor should encourage the Myanmar Overseas Employment Agencies 


\section{International Spotlight 9: Strengthening public employment services in China}

China's Rural Migrant Skills Development and Employment Project has helped strengthen public employment services. The project provided assistance to three provinces between 2008 and 2015, which improved public employment services and expanded the provision of labor market information. The project had two components: The first component established employment service centers in rural areas and expanded the labor market information system to local areas. The second created regulations and standards for public employment services and for the licensing and accreditation of private employment service providers. This support was offered to individual provinces:

- Creating an integrated urban-rural management information system (MIS) that contains information on jobseekers to assist with job matching;

- Establishing local "one-stop shops" to provide employment services, social security, legal aid, residential registration, and other public services to local and migrant jobseekers;

- Connecting townships to the county-level labor market information system, including through investments in physical infrastructure;

- Training for employment services staff on employment laws; and

- Developing standards for public employment services.

Source: Authors.

\section{International Spotlight 10: Providing recruitment services to increase the employment of young women in India}

Labor market information and job-placement assistance provided to women in rural India increased the likelihood of them entering the labor market or obtaining more schooling or training. There had been little awareness of jobs in the business process outsourcing (BPO) industry in India, and limited knowledge on how to access them. An intervention assigned eight BPO recruiters to provide recruitment sessions to rural women, sessions that were repeated one and two years after the original ones were offered. These recruitment sessions included:

- An overview of the BPO sector (such as types of jobs, compensation, names of firms currently or frequently looking for workers)

- Strategies for applying to jobs (like creating and submitting resumes)

- Interview lessons and tips, including practice interviews

- Assessment of English language skills

Attendees were allowed to contact the recruiters for free throughout the three years of the program.

Source: Authors based on Jensen (2012). 


\section{International Spotlight 11: The market for employment services in Australia}

Australia has developed a market for employment services that uses public financing to compensate private service providers based on their performance. The system includes several key components.

- Outcome-based contracting. Australia's system relies on outcome-based contracting. Payment of training providers depends on the successful placement of jobseekers in work. Providers and the managers of the contracts expend significant effort to track these outcomes; a star ratings system is used to assess the performance of providers on their actual performance, versus their expected performance, given the characteristics of both the jobseekers and the labor market.

- Monitoring. The providers of employment services are monitored closely according to a compliance framework that includes independent quality assurance, risk-based and random audits, and an assessment based on administrative data. Providers that underperform are sanctioned with a loss of rights to tender and a loss of market share.

- Data. The information technology (IT) system used to manage the employment services system is essential for administering and monitoring the market. The IT system facilitates information exchange between federal government agencies and between the government and service providers. The Federal Department of Employment runs the IT system.

Source: Authors.

Federation (MOEAF) to continue implementing its Code of Conduct and maintain its monitoring committee. MOEAF has partnered with the ILO and MOLIP to create a self-enforcement mechanism for overseas employment agencies. The mechanism's Code of Conduct encourages recruitment agencies to protect the rights of migrants and improve service quality. Of the 258 licensed agencies, 183 had signed the Code of Conduct as of late 2018 (ILO 2018). The mechanism also includes a Code Compliance and Monitoring Committee. There are plans to use the Code of Conduct in several ways. First, overseas employment agencies would be ranked for their compliance with the Code, using a star system: one star implies weak compliance, and three stars implies full compliance (ILO
2018). Second, MOLIP will provide awards to agencies in recognition of their performance. Finally, destination countries are encouraged to only use recruitment agencies that have signed the Code of Conduct (this system is in place in Japan). The Department of Labor could adopt the ranking system by providing administrative data and other information about recruitment agencies to MOEAF, by publishing the rankings, and making the results available to interested jobseekers at LEOs and MRCs. The Department could also explore the possibility of offering incentives to recruitment agencies to sign the Code of Conduct and be ranked in the star system. These incentives could include priority processing or relaxed scrutiny for demand letters. A similar system could be considered for 
rating internal recruitment agencies, as part of the creation of the market for training services described above. The Department of Labor could also advocate that the Code Compliance and Monitoring Committee incorporate migrants into the committee (they are not currently represented).

LEOs and MRCs could also be more actively involved in the oversight of internal and international recruitment. Despite having knowledge about local labor markets and local recruitment actors, LEOs and MRCs do not oversee these actors. Their engagement could serve two functions. First, reaching out to actors involved in recruitment could provide additional insight into the functioning of local labor markets. Second, oversight of these actors could uncover informal recruitment practices at the local level, which drive up the cost of migration for internal and international migrants.

\section{Strengthen the assistance provided} to migrant workers while they are abroad. International migrants are vulnerable while they are employed abroad. The responsibilities of overseas employment agencies to repatriate migrant workers either after the expiration of their employment term, or in the case of distress or emergency during their term, is not currently specified in the LROE. This creates uncertainty and can result in migrants becoming informal migrants, if there is a misunderstanding about who is responsible for organizing their return, including the financing for that return. A migrant welfare fund financed through general revenues or through fees from recruitment agencies, employers, or migrant workers could be considered. These funds typically provide insurance and legal help while migrants are abroad, and they assist with repatriation (International Spotlight 12). Myanmar could also consider introducing joint and several liability for recruitment agencies, where they are responsible for any claim or liability arising from contract infringements, such as unpaid wages or repatriation incurred by the employer. Such a system incentivizes recruitment agencies to work with reliable employers and to oversee the treatment of foreign workers while they are employed overseas (Testaverde et al. 2017). The Philippines currently uses joint and several liability. Joint and several liability in Myanmar would require legal changes and a significant capacity to implement, and so could be considered in the longer term.

6. Explore diaspora engagement policies. Policies to engage with and encourage the return of Myanmar's diaspora could bring financial and human capital resources back to Myanmar. It could also enhance the knowledge of local experts and offer financial connections to destination countries. So far, these policies seem to be absent in Myanmar. Myanmar could explore such policies, perhaps starting with creating a database of expatriate Myanmar workers that could be linked to Myanmar-based workers in the same occupation or sector (International Spotlight 13). 


\section{International Spotlight 12: Migrant worker welfare funds in the Philippines and in India}

The Overseas Workers Welfare Administration (OWWA) is the main agency responsible for the welfare of migrant workers from the Philippines and their dependents. A mandatory US $\$ 25$ fee, which can be paid by the migrant worker or their employer, is required to become a member of OWWA. The fee is due when the migrant receives an employment contract. Membership is for the duration of the contract and can be renewed when a new contract is signed. OWWA's services include insurance and legal assistance to migrant workers while they are abroad, but also before they depart and after they return home. Services while abroad include legal assistance and insurance in the case of disability and death. OWWA is responsible for repatriation assistance, regardless of membership. Repatriation assistance includes return tickets, airport assistance, accommodations, medical referrals, and domestic transportation (Thimothy et al. 2016). The agency also provides educational scholarships to the dependents of migrant workers; for example, the Education and Livelihood Assistance Program provides funds to the survivors of deceased migrant workers for education as well as livelihood assistance (Thimothy et al. 2016). OWWA maintains 31 posts abroad in 25 countries and has 17 offices in the Philippines. OWWA has 377 permanent staff, and had 1.8 million members in 2014.

The Ministry of External Affairs in India established the Indian Community Welfare Fund (ICWF) in 2009. They have 43 missions in countries with a large Indian population. The ICWF provides needs-based support in emergency situations. Assistance includes lodging, air travel, legal assistance, transportation of deceased individuals, and emergency medical care. The government provides funds for the ICWF (Thimothy et al. 2016).

Source: Authors.

\section{International Spotlight 13: Engaging diaspora from countries around the world}

Many countries engage their diaspora to encourage development at home. The Researchers and Scientists Abroad program (RAICES) in Argentina has developed networks of scientists living abroad and connected them with scientists at home (Dickerson and Özden 2018). The program has an annual budget of US $\$ 300,000$ under the Ministry of Science and Technology, which is used for travel expenses, salaries, information dissemination, translation, and accreditation. The program facilitates short stays by scientists of between one and four months. The program has also resulted in the creation of a large database of diaspora scientists from Argentina. The Ethiopian Diaspora Volunteer Program (EDVP) is a similar program focused on medical professionals. Several countries have tried to establish databases of talented diaspora abroad to help create knowledge networks and connect diaspora with job opportunities at home. These include the Philippines' Brain Gain Network, Jamaica's diaspora mapping project, Colombia's RedEsColombia, and Bosnia and Herzegovina's Who Is Who in BiH project. These databases typically include the location of the talented diaspora member, their skills and background, and information to promote exchange between people and firms in the home country and those abroad.

Source: Authors. 


\section{Incorporating financial assistance into ALMPs}

Financial assistance for poorer individuals could help connect those jobseekers to jobs in other locations, but it could also generate livelihood opportunities at home
(Table 4.6). Table 4.6 summarizes how financial assistance could be incorporated into ALMPs. The follow section elaborates.

Table 4.6

Policy recommendations for financial assistance

\begin{tabular}{|c|c|c|}
\hline \multicolumn{3}{|c|}{ Incorporating financial assistance into ALMPs } \\
\hline Recommendation & Short term & Longer term \\
\hline $\begin{array}{l}\text { 1. Explore the } \\
\text { potential of financial } \\
\text { assistance to } \\
\text { connect jobseekers } \\
\text { to jobs in other } \\
\text { locations }\end{array}$ & & $\begin{array}{l}\text { - Explore targeted subsidies for } \\
\text { job searches or transportation } \\
\text { - Explore predeparture loans for } \\
\text { international migrants }\end{array}$ \\
\hline $\begin{array}{l}\text { 2. Explore the } \\
\text { potential } \\
\text { of financial } \\
\text { assistance to } \\
\text { link people } \\
\text { to livelihood } \\
\text { opportunities }\end{array}$ & $\begin{array}{l}\text { Explore the potential for remittance-backed } \\
\text { loans } \\
\text { - Explore the possibility of implementing } \\
\text { economic inclusion programs in partnership } \\
\text { with CSOs, NGOs, and international } \\
\text { development agencies }\end{array}$ & $\begin{array}{l}\text { - Explore pilots to reintegrate } \\
\text { returning migrants, perhaps } \\
\text { targeting groups of migrants in } \\
\text { specific occupations or sectors } \\
\text { - Explore opportunities to } \\
\text { scale up economic inclusion } \\
\text { programs linked to broader } \\
\text { social protection schemes }\end{array}$ \\
\hline
\end{tabular}

Source: Authors.

1. Explore the potential of financial assistance to help connect jobseekers to jobs in other locations. Financial constraints can prevent potential migrant workers, particularly those who are poorer and less skilled from migrating (McKenzie and Rapoport 2007). Easing that cost constraint through financial assistance could enable workers to migrate both internally and internationally (Testaverde et al. 2017). This financial assistance could take different forms. Subsidies could be designed to encourage people to search for jobs in other areas. A small subsidy was initially found to be successful in Bangladesh, although follow-up evaluations found less certain benefits (International Spotlight 14). Loans could also be targeted to international migrants, in the form of a predeparture loan. These could be tailored to the particular needs of migrants, for example, by being paid only when work contracts and travel documents are verified; by incorporating a grace period for repayment, until the migrant begins work abroad and can remit funds; and by being linked to predeparture orientation. Loans for international migrants have been made available in Bangladesh (International Spotlight 15). 


\section{International Spotlight 14: Providing transportation subsidies in Bangladesh}

A transportation subsidy in Bangladesh has helped stimulate migration while also increasing income and consumption. Rural areas of Bangladesh suffer lean seasons between the planting and harvesting of crops, which can lead to hunger and can reinforce poverty. While some households are able to send a family member to work in urban and periurban areas during their lean season, very poor ones cannot. In response, Evidence Action's No Lean Season ${ }^{\text {a }}$ provides a travel subsidy of US $\$ 20$ to rural laborers so that a household member can look for work during the lean season. This subsidy is about equivalent to a round-trip bus fare to nearby urban areas. The intervention has had several effects. First, households receiving the subsidy were more likely to migrate in the current lean season and in subsequent years. Second, income and consumption increased. Finally, even households that did not receive the subsidy benefited, in part because their migrating neighbors reduced the labor force competition for the few jobs available. A recent effort to scale up the program did not show positive effects, but it is still being evaluated. A similar program is being prepared in Indonesia.

a See https://www.evidenceaction.org/beta-no-lean-season/\#the-solution-no-lean-season (last accessed January 14, 2019). Source: Authors.

\section{International Spotlight 15: Providing migration loans to international migrants in Bangladesh}

An initiative in Bangladesh provides financial support to international migrants. BRAC, an NGO in Bangladesh, has created a migration loan program for international migrants. The program, which began in 2011, offers loans of between US\$300 and US\$3,700 to migrants with a one-month grace period and a maximum two-year payback. Migrants can obtain the loans only after work contracts and travel documents are verified. Recipients receive predeparture orientation services. The loan is designed with the intention of both financing migration and supporting household members left behind until the migrant starts working abroad. The loans help would-be migrants leave the country for work, despite financial constraints, and it also helps migrants avoid abuse by recruitment agencies.

Source: Authors.

2. Explore the potential of financial assistance to link people to livelihood opportunities. The remittances sent by workers overseas to their families back home in Myanmar offer an opportunity for those families. Financial products targeted to the needs of migrants and their families could help leverage this opportunity even further. Loan products can be created backed by the remittances that the families of migrants receive from abroad. This type of loan can help households finance more significant investments based on the remittance flows (Testaverde et al. 2017). The Department of Labor could explore partnerships with NGOs, CSOs, and international development agencies to develop this product.

Financial assistance could also help returning migrants reintegrate into 
the Myanmar labor market. This reintegration is important for both the migrants themselves and for Myanmar's economy, which could benefit from returned migrants' higher skill levels. Reintegration policies are largely absent in Myanmar. Myanmar could consider a pilot for returning migrants, perhaps targeting specific groups of migrants, such as those returning from specific occupations or sectors. The Philippines has developed a suite of programs targeted to returning migrants (International Spotlight 16).

Finally, financial constraints can prevent households in Myanmar from being able to invest in productive livelihood activities. Financial assistance could help jumpstart more highly skilled entrepreneurs and the smaller livelihood activities of less-skilled households. For instance, economic inclusion programs incorporate a package of services that typically include technical and lifeskills training, financial assistance, and mentoring. These programs have been effective in linking beneficiaries with livelihood opportunities and in reducing poverty (Bandiera et al. 2017; Banarjee et al. 2015). In the short run, Myanmar could explore partnerships with NGOs, CSOs, and international development agencies to implement these programs in Myanmar. In the longer run, Myanmar could explore how these livelihood programs could be scaled up and linked to the country's broader social protection schemes.

\section{International Spotlight 16: Reintegrating returning migrants in the Philippines}

The Philippines has a suite of programs targeted to people returning from employment abroad. These are provided by the Department of Labor and Employment (DOLE) and several agencies within it, such as the Overseas Workers Welfare Association (OWWA) and the National Reintegration Center for Overseas Foreign Workers (NRCO).

DOLE's Assist WELL (Welfare, Employment, Legal, and Livelihood) centers connect returning migrants (particularly those returning because of distress) with welfare, employment, livelihood, and legal assistance. Employment assistance includes skills assessment and certification, job placement, and referral for local and overseas employment via regional labor offices. Livelihood and entrepreneurship development training is also available. Their welfare assistance includes help at the airport, temporary shelter and accommodation, emergency medical assistance, transportation assistance, and counseling.

Three livelihood programs are designed to create income-generating opportunities for returning migrants. The Balik-Pinay! Balik-Hanapbuhay! program (BPBH) is a livelihood support program that provides skills, entrepreneurship, and financial literacy training; starter kits; and other services at no expense to returning migrant workers. The program is targeted to returning migrant women who left work abroad due to conflict, policy change, recruitment difficulties, or human trafficking. The NRCO manages these projects. The Philippines Overseas Labor Offices, which are overseas outposts that help manage migration from the Philippines, identify beneficiaries, conduct skills trainings, and issue certificates of completion. The Department of Labor and Employment and OWWA then issue vouchers for starter kits to migrant workers 
when they return. The Enterprise Development and Loan Program, which the NRCO runs with the Land Bank of the Philippines and the Development Bank of the Philippines, facilitates enterprise development through fixed interest loans and entrepreneurship support. Potential borrowers undergo entrepreneurial development training delivered by OWWA, the Department of Trade and Industry, and the Land Bank; submit business plans; and submit their loan applications for processing by the Land Bank. Loans can be up to PhP2 million $(U S \$ 38,740)$ for individuals and PhP5 million (US\$96,850) for group borrowers. The Livelihood Development Assistance Program is targeted to returning undocumented migrant workers, and it provides beneficiaries with a business start-up kit of PhP10,000 (US\$194), along with small business training and a financial awareness seminar. Potential beneficiaries submit applications to regional Department of Labor and Employment offices.

The Sa 'Pinas, Ikaw ang Ma'am/Sir (SPIMS) project, which is run in part by the Department of Labor and Employment and the Department of Education, helps household workers find teaching positions in the Philippines. People interested in the program must be current or former migrant household workers who have passed the Licensure Examination for Teachers (LET) in the Philippines, and have taught within the last 5 years, or they must take a refresher course. The Department of Education then evaluates applicants for teaching positions.

Source: Authors.

\section{A vision for reform}

Many policy reforms are necessary to address the areas for improvement and the potential gaps in ALMPs in Myanmar. Prioritizing these actions is important for success; those targeted to the short run recognize that only reforms with the highest likelihood for impact should be initiated, given the budget constraints. Long-term reforms are more ambitious and may require additional resources. Beyond this short- and long-term prioritization, several themes emerge from the policy recommendations, and these provide a rubric to structure how to think about reform (Figure 4.2).

First, investments will need to be made strategically to strengthen ALMPs. In the short term, budget constraints make strengthening the existing services preferable to significantly expanding them. A short-term priority is an improved information system that could save the time and resources related to registering jobseekers and job vacancies, and to managing demand letters (for international jobseekers). In the longer term, when budget constraints are relaxed, expansion of these services should be considered.

Second, coordination will need to be improved to fill the gaps in services. In the short term, this coordination will need to focus on supplementing the services provided by the Department of Labor with those provided by the private sector, NGOs, CSOs, and international development agencies. The Department of Labor can coordinate with the private sector to address the needs of less-skilled individuals, while partnering with NGOs, CSOs, and international development agencies to expand the existing efforts of these groups to link jobseekers with good 
jobs. In the longer term, the Department of Labor can take on more of the services currently provided by NGOs, CSOs, and international development agencies, and to identify areas where these groups can complement public services.

Third, technology will need to be deployed to improve the efficiency of service delivery. The need to invest in a better information management system is clear; however, in the short term, the Department of Labor can also work with NGOs, CSOs, and international development agencies to incorporate technology-informed tools into their delivery of ALMP services. To take one example, the data held by the Department of Labor on overseas employment agencies could significantly improve the value added of existing mobile applications developed by NGOs for international migrant workers. In the longer term, the Department of
Labor can explore ways that technology can be used to provide its own client-facing services.

Fourth, the collection, analysis, and dissemination of data will need to be strengthened. In the short term, the focus will need to be on improving the dissemination of existing data, while in the longer term, the focus can shift to collection and analysis as well.

Action is necessary on many fronts if ALMPs are to improve the ability of jobseekersparticularly the less-advantaged ones who are currently overlooked by the private sector-to find jobs at home and abroad more quickly and easily. Strategic investments, better coordination, and leveraging technology and data can guide this action.

Figure 4.2

Priority areas for reforming ALMPs

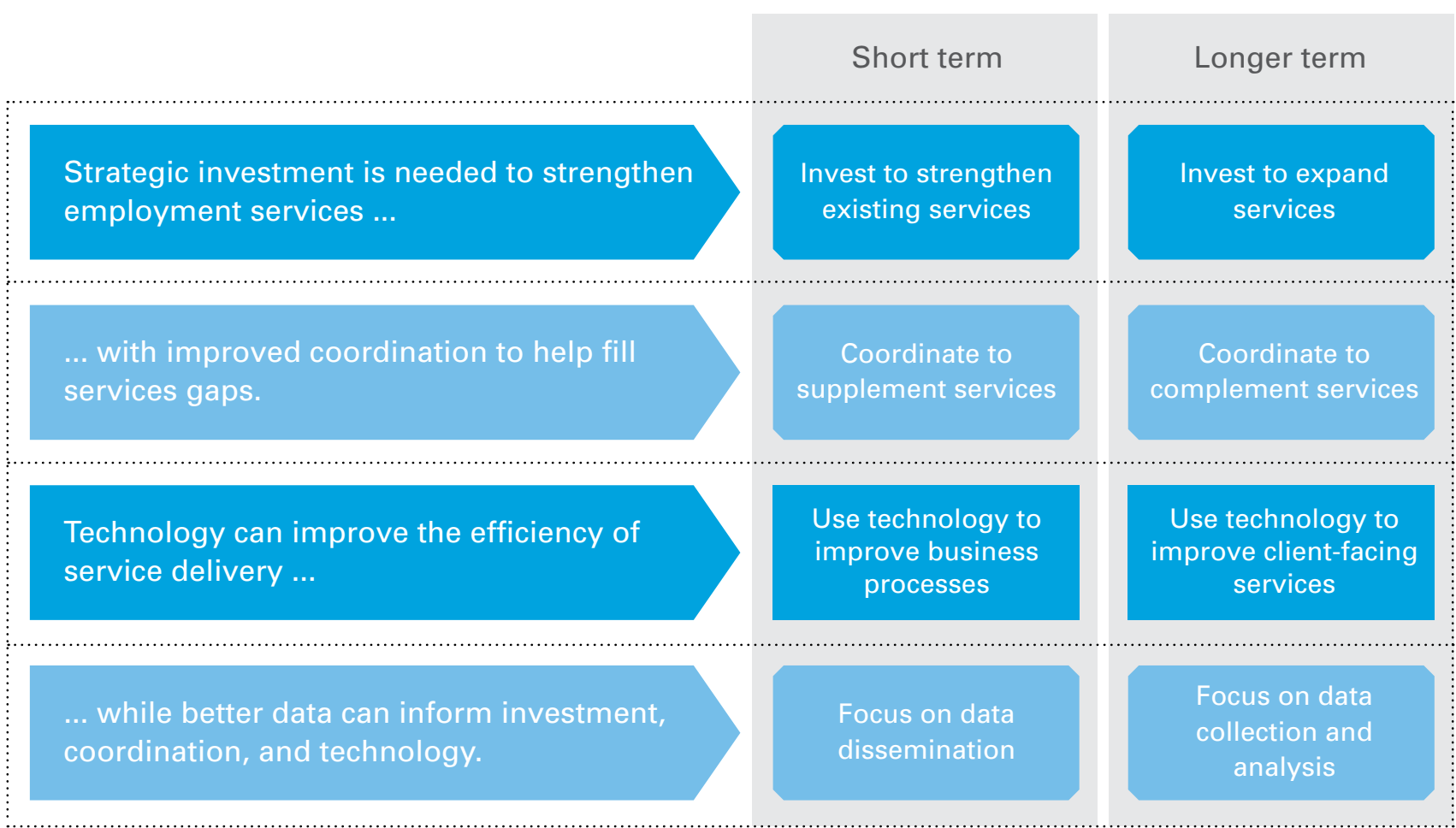




\section{References}

Abebe, Girum, Stefano Caria, Marcel Fafchamps, Paolo Falco, Simon Franklin, Simon Quinn, and Forhad Shilpi. 2017. "Job Fairs: Matching Firms and Workers in a Field Experiment in Ethiopia," Policy Research Working Paper 8092, World Bank, Washington D.C.

Ambito, Julyn S., and Melissa Suzette L. Banzon. 2011. "Review of Philippine Migration Laws and Regulations: Gains, Gaps, Prospects." Discussion Paper Series 2011-37, Philippine Institute for Development Studies, Makati City.

Anchustegui, Iza M. 2010. "An Evaluation of the Implementation of the Pre-Departure Orientation Seminar (PDOS) by OWWA-Accredited PDOS Providers." ILS Discussion Paper Series 112010, Institute for Labor Studies (ILS), Manila.

Asis, Maruja M.B., and Dovelyn Rannveig Agunias. 2012. "Strengthening Pre-Departure Orientation Programmes in Indonesia, Nepal and the Philippines." Migration Policy Institute, Washington, DC.

Bandiera, Oriana, Robin Burgess, Narayan Das, Selim Gulesci, Imran Rasul, and Munshi Sulaiman. 2017. "Labor Markets and Poverty in Village Economies," The Quarterly Journal of Economics 132(2):811-70.

Banarjee, Abhijit, Esther Duflo, Nathaneal Goldberg, Dean Karlan, Robert Osei, William Parienté, Jeremy Shapiro, Bram Thuysbaert, and Christopher Udry. 2015. "A Multifaceted Program Causes Lasting Progress for the Very Poor: Evidence from Six Countries," Science 348(6236):1260799-1-16.

Beam, Emily A. 2016. "Do Job Fairs Matter? Experimintal Evidence on the Impact of Job-Fair Attendance," Journal of Development Economics 120:32-40.

Beam, Emily A., David Mckenzie, and Dean Yang. 2016. "Unilateral Facilitation Does Not Raise International Labor Migration from the Philippines," Economic Development and Cultural Change 64(2):323-68.

Dammert, Ana C., Jose Galdo, and Virgilio Galdo. 2015. "Integrating Mobile Phone Technologies into Labor-Market Intermediation: A Multi-Treatment Experimental Design," IZA Journal of Labor \& Development 4:11.

Dickerson, Sarah, and Çağlar Özden. 2018. "Return Migration and Diaspora Engagement." In Handbook on Migration and Globalization, edited by Anna Triandafyllidou. Cheltenham, U.K.: Edward Elgar Publishing.

Doi, Yoko, David McKenzie, and Bilal Zia. 2014. "Who You Train Matters: Identifying Combined Effects of Financial Education on Migrant Households." Journal of Development Economics $109(\mathrm{C}):$ 39-55. 
DOLE (Philippines Department of Labor and Employment). 2014. "Baldoz Orders OWWA to Review the PDOS and Weed Out 'Undesirable' Providers." Department of Labor and EmploymentNews.

Fuller, Theodore D., Paul Lightfoot, and Peerasit Kamnuansilpa. 1985. "Toward Migration Management: A Field Experiment in Thailand," Economic Development and Cultural Change 33(3):601-21.

GIZ and ILO (International Labour Organization). 2016. "From Pakistan to the Gulf Region: An Analysis of Links between Labour Markets, Skills and the Migration Cycle." GIZ and ILO, Pakistan.

HRDF (Human Resources Development Fund). 2018. National Workforce Human Capital Development Blueprint: 2018-2025. Kuala Lumpur: HRDF.

ILO (International Labour Organization). 2015. "Strengthening Post-arrival Orientation Programs for Migrant Workers in ASEAN." Policy Brief Issue No. 2, ILO Regional Office for Asia and the Pacific, Bangkok.

ILO (International Labour Organization). 2017. "Building Labour Migration Policy Coherence in Myanmar." ILO, Yangon.

ILO (International Labour Organization). 2018. "Implementation of Recommendations from the $3^{\text {rd }}$ to $10^{\text {th }}$ ASEAN Forum on Migran Labour (AFML): Progress Review Background Paper for the $11^{\text {th }}$ ASEAN Forum on Migrant Labour (AFML)," ILO, Geneva.

IOM (International Organization for Migration) and Scalabrini Migration Center. 2013. "Country Migration Report: The Philippines 2013." IOM, Makati City, Philippines.

Jensen, Robert. 2010. "The (Perceived) Returns to Education and the Demand for Schooling," The Quarterly Journal of Economics 125(2):515-48.

Jensen, Robert. 2012. “Do Labor Market Opportunities Affect Young Women's Work and Family Decisions? Experimental Evidence from India," The Quarterly Journal of Economics 127(2):75392.

Joshi, Ashish. 2018. "Building an Integrated Management Information System Platform for the Department of Labour: Current Technical Gaps and Recommendations," World Bank, Washington, D.C.

McKenzie, David, and Hillel Rapoport. 2007. "Network Effects and the Dynamics of Migration and Inequality: Theory and Evidence from Mexico." Journal of Development Economics 84 (1): $1-24$.

Napier-Moore, Rebecca. 2017. "Protected or Put in Harm's Way? Bans and Restrictions on Women's Labour Migration in ASEAN Countries." ILO and UN Women.

Nguyen, Trang. 2008. "Information, Role Models and Perceived Returns to Education: Experimental Evidence from Madagascar," Mimeo.

POEA (Philippines Overseas Employment Administration). 2016. "Governing Board Resolution No. 06 Series of 2016." 
Shrestha, Maheshwor, Ahmed Mushfiq Mobarak, and Iffath Anwar Sharif. 2019. Migration and Remittances: The Impacts of a Government Intermediated International Migration Program. Washington, DC: World Bank.

Testaverde, M., H. Moroz, C. H. Hollweg, A. Schmillen. 2017. Migrating to Opportunity: Overcoming Barriers to Labor Mobility in Southeast Asia. Washington, DC: World Bank.

Thimothy, Rakkee, S. K. Sasikumar, Padmini Ratnayake, and Alvin P. Ang. 2016. "Labour Migration Structures and Financing in Asia." International Labour Organization (ILO), Bangkok.

Wickramasekara, Piyasiri. 2016. Review of the Government-to-Government Mechanism for the Employment of Bangladeshi Workers in the Malaysian Plantation Sector. Geneva: International Labour Organization.

Wiswall, Matthew, and Basit Zafar. 2015. “How Do College Students Respond to Public Information about Earnings?" Journal of Human Capital 9(2):117-69.

World Bank. 2019. "Using Targeted Labor Market Information Tools To Improve Employment Services in Vietnam." World Bank, Washington, D.C. 

